UNIVERSIDADE DE SÃO PAULO

JULIANA SÍPOLI COL

COERÊNCIA, PONDERAÇÃO DE PRINCÍPIOS E VINCULAÇÃO À LEI: MÉTODOS E MODELOS 


\section{JULIANA SÍPOLI COL}

\section{COERÊNCIA, PONDERAÇÃO DE PRINCÍPIOS E VINCULAÇÃO À LEI: MÉTODOS E MODELOS}

Dissertação apresentada à Comissão de PósGraduação (CPG) da Faculdade de Direito da Universidade de São Paulo, como requisito parcial para a obtenção do título de Mestre em Filosofia e Teoria Geral do Direito.

Orientador: Prof. Dr. Juliano Souza de Albuquerque Maranhão. 


\title{
COERÊNCIA, PONDERAÇÃO DE PRINCÍPIOS E VINCULAÇÃO À LEI: MÉTODOS E MODELOS
}

\begin{abstract}
Dissertação apresentada à Comissão de PósGraduação (CPG) da Faculdade de Direito da Universidade de São Paulo, como requisito parcial para a obtenção do título de Mestre em Filosofia e Teoria Geral do Direito.
\end{abstract}

Aprovada em:

BANCA EXAMINADORA

Prof. Dr. Juliano Souza de Albuquerque Maranhão

Universidade de São Paulo 
A Laércio e Silvia, pelo muito que lhes devo e jamais poderei retribuir na mesma proporção. Ao João, pela companhia e abnegação, À Ana, pelas palavras estimuladoras. 


\section{AGRADECIMENTOS}

Agradeço ao Criador pela existência e proteção. Sem fé, religiosa ou não, é quase impossível caminhar.

Aos meus pais pelo apoio e sustentação no sentido mais amplo dos termos. Pela companhia e fortalecimento nos momentos difíceis, pelos consolos, estímulos, dedicação incansável. Pelas conversas, conquistas, desafios e dores compartilhados. Pela confiança e amizade indizíveis. Pelo amor constante. Por existirem em minha vida.

À Ana Flávia, com quem compartilho muito de meu ser. Quiçá um alter ego. Certamente alguém que compartilha das angústias e de tantos outros sentimentos que fazem parte do viver. Uma companheira de vida e de ideal.

Ao João, com incomensurável gratidão por todas as madrugadas de traslado nas dezoito horas semanais de viagens entre São Paulo e Maringá, ocasiões em que constantemente privou-se de seu sono para que eu pudesse, finalmente, chegar em casa. Pelo companheirismo constante, pelo auxílio imprescindível, pelo carinho, pela presença e pelo amor.

Ao professor Juliano Maranhão pela oportunidade que me deu de ingresso no Mestrado. Essa foi uma experiência de profundas repercussões em minha vida, não apenas do ponto de vista intelectual, mas, sobretudo, pessoal, em termos superação e autoconhecimento.

A todos os professores que participaram de minha vida acadêmica, em especial aos docentes ministrantes das disciplinas cursadas no Programa de Pós-Graduação da FDUSP e aos professores Tercio Sampaio Ferraz Junior e Samuel Rodrigues Barbosa pelas sugestões valiosas no exame de qualificação.

Aos amigos de Maringá que tanto me apoiaram nos momentos difíceis. E à Ligia que me acolheu em sua casa em São Paulo.

A todos aqueles que, ainda que despercebidos, estiveram ao meu lado, auxiliando-me e fortalecendo-me nesses passos da jornada. Muito obrigada! 
"Among reasons why this is a requirement of legal justification is that there are limits to the ambit of legitimate judicial activity: judges are to do justice according to law... Although this does not and cannot mean that they are only to give decisions directly authorized by deduction from established and valid rules of law, it does and must mean that in some sense and in some degree every decision, however acceptable or desirable on consequentialist grounds, must also be warranted by the law as it is". (MACCORMICK, Neil. Legal Reasoning and Legal Theory. New York: Oxford University Press, 2003, p. 107). 


\section{RESUMO}

O objeto da discussão é a racionalidade das decisões judiciais em casos em que se constata conflito de princípios ou entre princípios e regras, casos esses considerados difíceis, uma vez que não há no ordenamento jurídico solução predeterminada que permita mera subsunção dos fatos à norma. São examinados métodos alternativos ao de subsunção. O primeiro é o método da ponderação, difundido principalmente por Robert Alexy, com suas variantes. Entretanto, o problema que surge com a aplicação do método da ponderação é da 'imponderabilidade' entre ponderação e vinculação à lei, ou seja, a escolha dos "pesos" dos princípios e sua potencial desvinculação da lei. O segundo modelo, chamado de coerentista, busca conferir alguma racionalidade e fornecer critérios que poderiam explicar escolhas entre valores conflitantes subjacentes à legislação e mesmo aos "pesos" do método de ponderação. Dentro do modelo coerentista, examina-se em particular a versão "inferencial" que explora a coerência entre regras e princípios pela inferência abdutiva dos princípios a partir das regras. A aplicação dos diferentes modelos é feita em duas decisões prolatadas pelo Supremo Tribunal Federal em casos de conflito de princípio, casos Ellwanger e de aborto de anencéfalos. O que não permite generalização, mas oferece ilustrações específicas das virtudes e vícios desses modelos de decisão.

Palavras-chave: Conflito de princípios; método da subsunção; método da ponderação; modelo coerentista; caso Ellwanger; aborto de anencéfalos. 


\begin{abstract}
The subject of this study is rationality of judgments when there is collision of principles or conflict between principles and rules, which are hard cases, since there is no predetermined solution in legal system that allows only subsuming facts to the norm. Alternative methods are then examined. The first is the method of weighting and balancing proposed mainly by Robert Alexy, in spite of its variants. However, the difficulty to apply such method is the 'weightlessness' between weighing and law binding, that is, the choice of "weight" of principles and its untying to the Law. The second model, called coherence model, intends to reach any rationality and provide criteria that could explain choices between conflicting values underlying Law and also the ascription of "weights" of the weighing and balancing method. In coherence model, it is studied especially its "inferential" version that explores coherence between rules and principles through abduction of principles from rules. These methods are tested in two decisions by Brazilian Supreme Court in cases of collision of principle, in Ellwanger and anencephalic abortion cases. That does not allow a general approach, but only specific outlines of the virtues and defects of these models of decision.
\end{abstract}

Keywords: collision of principles; subsumption method; weighting and balancing; coherence model; Ellwanger; anencephalic abortion. 


\title{
LISTAS DE ABREVIATURAS E SIGLAS
}

\author{
ADPF Arguição de Descumprimento de Preceito Fundamental \\ Art. Artigo \\ CC Código Civil \\ CF $\quad$ Constituição Federal de 1988 \\ CNTS Confederação Nacional dos Trabalhadores na Saúde \\ CP Código Penal \\ HC Habeas Corpus \\ ONU Organização das Nações Unidas \\ STF Supremo Tribunal Federal \\ STJ Superior Tribunal de Justiça \\ TJRJ Tribunal de Justiça do Rio de Janeiro \\ TJRS Tribunal de Justiça do Rio Grande do Sul
}




\section{SUMÁRIO}

INTRODUÇÃ

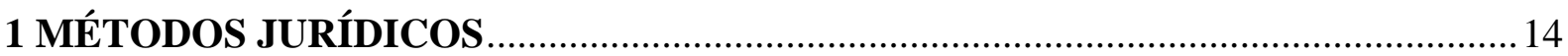

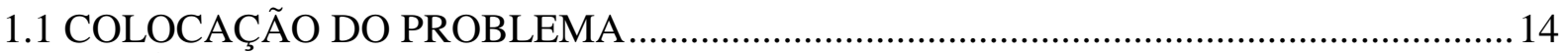

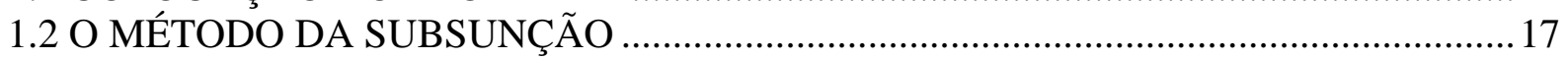

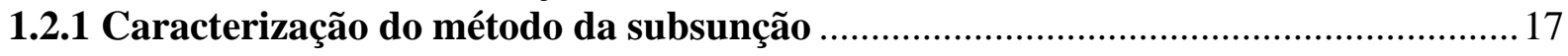

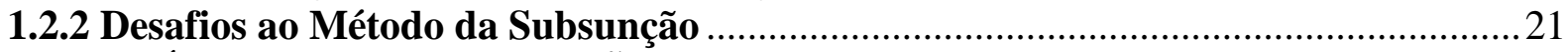

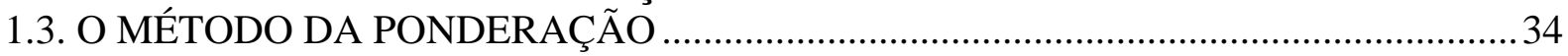

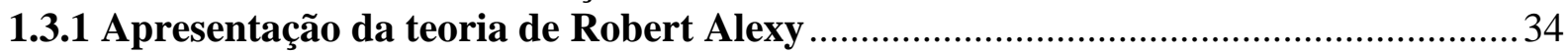

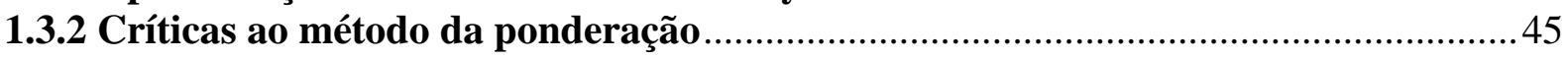

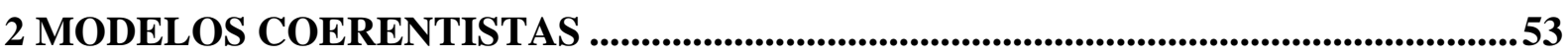

2.1 CONSIDERAÇÕES GERAIS SOBRE MODELOS COERENTISTAS NO DIREITO ...53

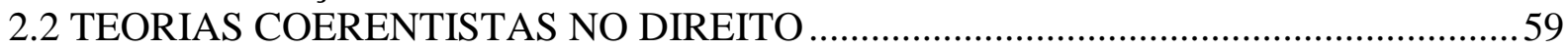

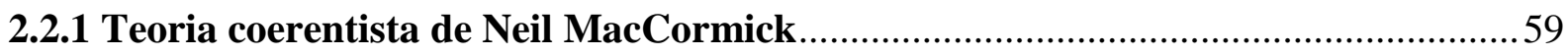

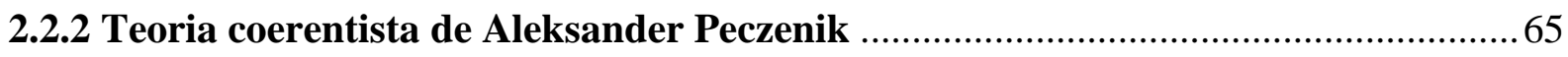

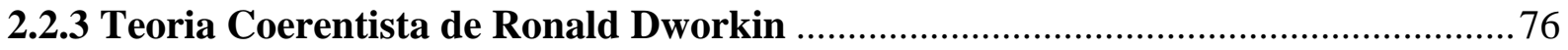

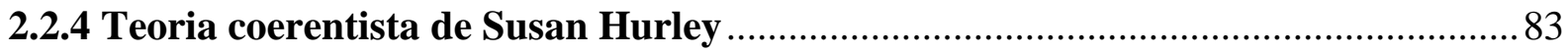

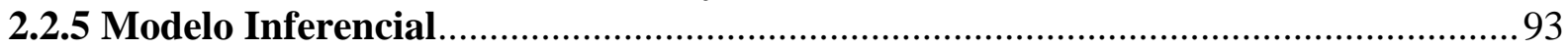

3 ANÁLISE DE CASOS: APLICAÇÃO DOS MÉTODOS E MODELO .........................105

3.1 CASO DO ABORTO DE FETOS ANENCÉFALOS (ADPF N N $^{\circ}$ 54-8/DF) ..................... 106

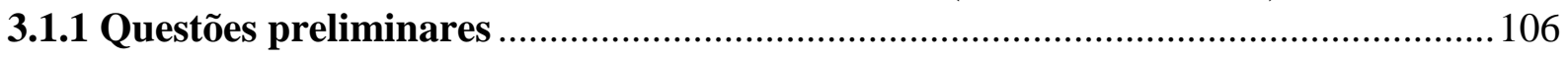

3.1.1.1 Síntese do caso e colocação do problema semântico preliminar................................. 106

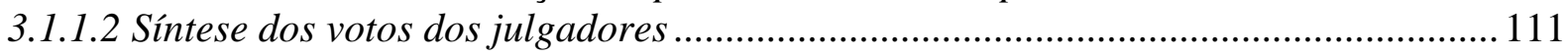

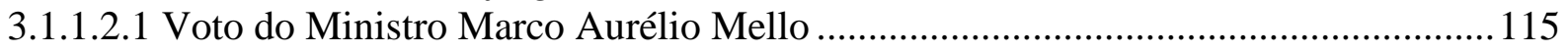

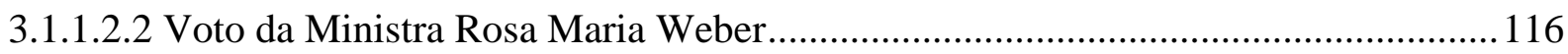

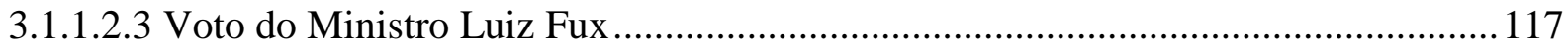

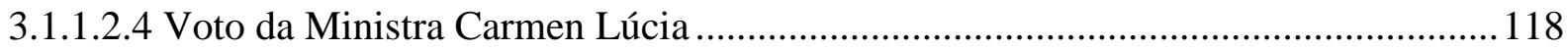

3.1.1.2.5 Voto do Ministro Ricardo Lewandowski .................................................................... 118

3.1.1.2.6 Voto do Ministro Carlos Ayres Britto ................................................................ 120

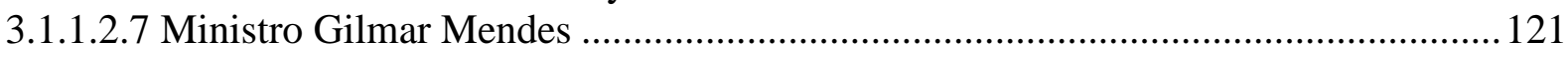

3.1.1.2.8 Voto do Ministro Celso de Mello .......................................................................... 123

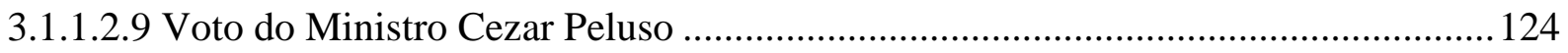

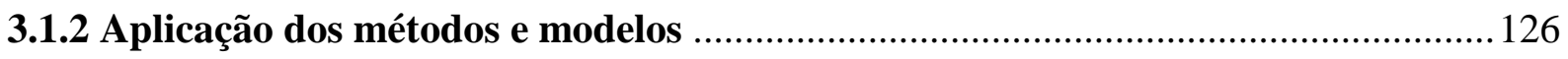

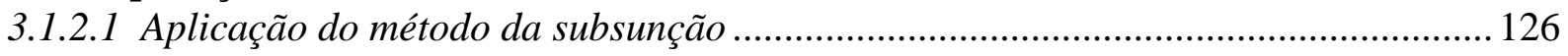

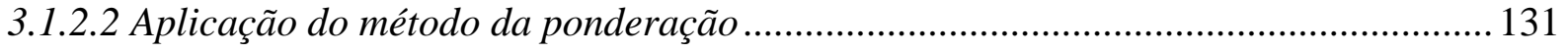

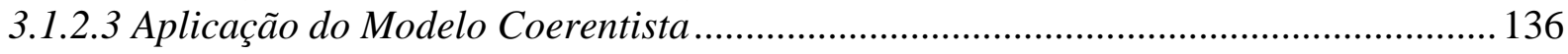

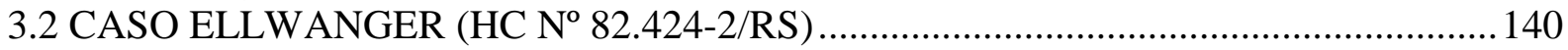

3.2.1 Questões preliminares ....................................................................................... 140

3.2.1.1 Síntese do caso e colocação do problema semântico preliminar............................... 140

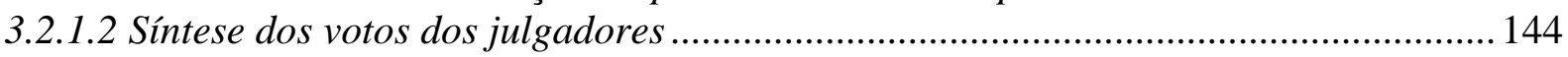

3.2.1.2.1 Voto do Ministro Moreira Alves .......................................................................... 145

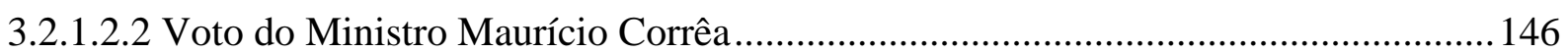

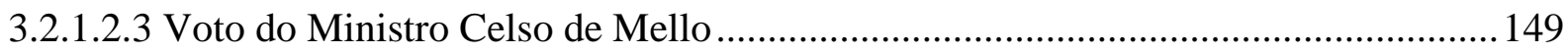

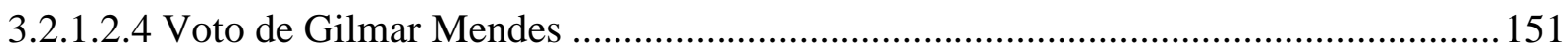

3.2.1.2.5 Voto do Ministro Carlos Velloso .......................................................................... 153 


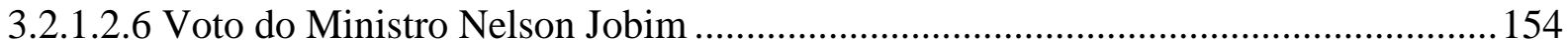

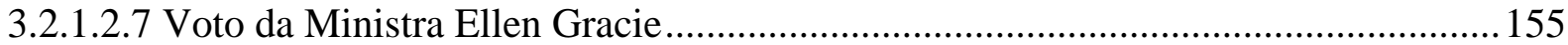

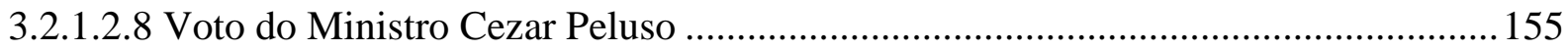

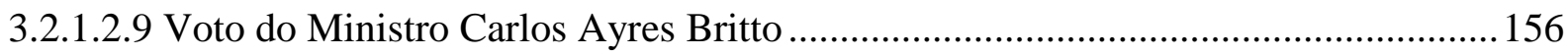

3.2.1.2.10 Voto do Ministro Marco Aurélio Mello .................................................................. 159

3.2.1.2.11 Voto do Ministro Sepúlveda Pertence: ................................................................ 162

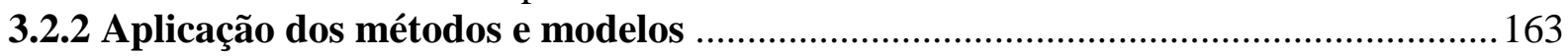

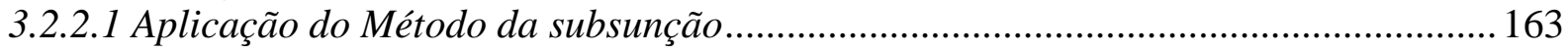

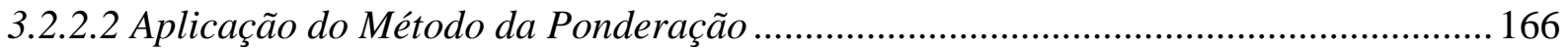

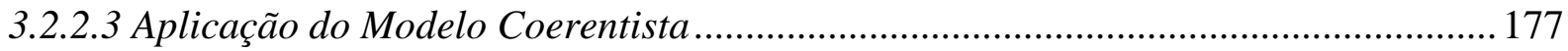

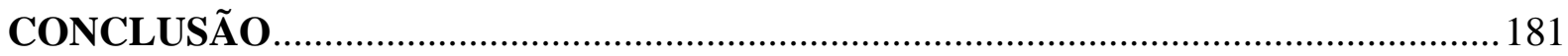

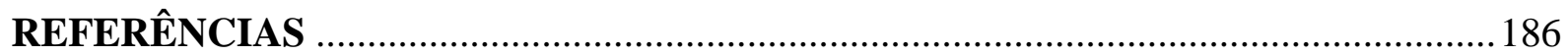




\section{INTRODUÇÃO}

Em Cartas Constitucionais contemporâneas características de Estados de Direito democráticos consagram-se diversos princípios em rol de direitos fundamentais. Tal é o caso da Constituição Federal brasileira de 1988, de caráter dirigente e aberto, pois além de salvaguardar os princípios inscritos, sobretudo, em seus Arts. $5^{\circ}$ e $6^{\circ}$, embora não apenas neles, também é dotada de normas que constituem verdadeiros programas de governo, a serem implementados pragmaticamente. Daí se vê que, ante tal conteúdo aberto, nem sempre é possível a aplicação consoante proposta subsuntiva clássica.

Ocorre que, tendo-se em vista a premissa do legislador racional, segundo a qual ele não criaria normas inexequíveis ou despropositadas, havendo coerência entre meios e fins e completude, sem redundância dos sistemas normativos, a aplicação subsuntiva do Direito era garantia da racionalidade decisória tendo-se em vista a premissa referida.

Já não é o caso dos tempos atuais. A premissa é claramente contrafática. Ante as Cartas constitucionais vazadas em princípios, revelam-se estes colidentes concretamente em diversos casos, colisão a ser previamente solucionada para o fim de se determinar a solução jurídica do caso e, então, levanta-se o problema da racionalidade decisória, quando não há mais certezas.

A discussão passa pelos métodos decisórios, mas não os toma enquanto objeto precípuo, e tampouco a definição de método e sua diferenciação de modelo, posto que são problemas demasiado intrincados para se inserir nesta modesta abordagem, em que não se tem o comprometimento com a verdade ou a correção.

O problema principal é voltado à delicada questão da aparente 'imponderabilidade' entre a ponderação de princípios, já que o método da ponderação é tomado como adequado e racional para a solução da colisão de princípios - potencialmente em aumento, pelas razões acima expostas -, e a vinculação à lei propalada pelo princípio da legalidade, também um dos corolários do Estado de Direito, com sua famosa propugnação de um governo de leis e não de homens.

A pesquisa, de caráter eminentemente descritivo, principia com a caracterização dos métodos decisórios no primeiro capítulo. Iniciando-se pelo método da subsunção, nomenclatura referente ao método dedutivo no Direito. Esse método assume que a conclusão já estaria contida nas premissas, o que se supunha que garantiria certeza e segurança, com soluções jurídicas gerais a partir de decisões políticas prévias. 
Não obstante, nota-se que a construção da premissa maior, que no caso seria a norma jurídica, nem sempre é de fácil alcance, por diversos problemas, como o uso pelo legislador de conceitos indeterminados, de conceitos valorativos, de cláusulas gerais, a atribuição de poder discricionário, a existência de lacunas normativas ou axiológicas, a constatação de inconsistências normativas, a despeito da presunção contrafática do legislador racional e, finalmente, o que é de maior relevo para o estudo, os conflitos entre princípios.

O método proposto por Robert Alexy para a solução do último problema, ou seja, da colisão de princípios - já que ele reserva o termo conflito para a inconsistência de regras - é o método da ponderação, considerado como adequado e racional para essa tarefa. A racionalidade desse método estaria assegurada, conforme o autor, pelo emprego da fórmula de peso, em que se evidenciariam os pesos atribuídos pelo julgador a cada princípio em contraposição, como justificativa do resultado obtido.

Não obstante, esse modelo é questionado e duramente criticado como método, em parte porque, segundo os críticos, não há em sua aplicação parâmetros objetivos para a aferição de pesos aos princípios em colisão, o que implicaria subjetivismo, quando não arbitrariedade; e não levaria a um resultado unívoco, permitindo plúrimas decisões, não havendo, pois, certeza e segurança com relação ao resultado, pondo-se em dúvida a vinculação do julgador à lei em tais casos.

Assim, o modelo coerentista, tratado no segundo capítulo do trabalho, surge não como mecanismo para se assegurar objetividade e univocidade decisória, mas como meio para a justificação das decisões judiciais. Em verdade, adota-se a nomenclatura modelos coerentistas, no plural, uma vez que se nota que as teorias coerentistas no Direito - já que o coerentismo não é exclusivo do campo jurídico - não apresentam orientação única, distinguindo-se em diversos pontos.

As teorias coerentistas clássicas são as de Neil MacCormick, Aleksander Peczenik e Ronald Dworkin, nas quais razões jurídicas acabam por colapsar com razões morais. Na proposta de Susan Hurley, ajustada a sistemas jurídicos de common law, embora bastante aproximada à de Ronald Dworkin, tem-se em vista razões mais estritamente jurídicas, adotando-se alguns precedentes judiciais como casos paradigmáticos, ou seja, casos em que as soluções adotadas são consensuais e, por tal razão, orientariam a solução de novos casos em que se constatasse conflito de princípios.

Esse modelo de Hurley pode ser transposto para o sistema jurídico romano-germânico usando-se a variante inferencial. Assim, busca-se a solução no próprio ordenamento jurídico tendo-se em vista, a partir de inferências abdutivas - que forneçam a melhor explicação 
possível para as normas jurídicas -, ponderação já levada a cabo pelo próprio legislador ao elaborar as normas postas. O que poderia sanar a 'imponderabilidade' entre ponderação de princípios e vinculação à lei, já que seria possível pautar-se na orientação do próprio legislador, tendo-se em vista os princípios explicativos das normas postas.

A aplicação desses modelos é feita no terceiro capítulo do trabalho em que são analisados dois casos decididos pelo Supremo Tribunal Federal. O primeiro caso é a Arguição de Descumprimento de Preceito Fundamental $n^{\circ}$ 54-8/DF, relatada pelo Ministro Marco Aurélio Mello, conhecido como caso do aborto de fetos anencéfalos. Nessa ação, iniciada em 2004 e julgada apenas no presente ano, discutia-se a possibilidade de antecipação terapêutica do parto - nomenclatura esta usada no intuito de se afastar o entendimento de que se tratasse de caso de crime de aborto - uma vez diagnosticada a anencefalia fetal.

A decisão do caso foi no sentido de permitir a antecipação do parto como não sendo caso típico de aborto. Embora os votos, na maioria, tenham-se seguido ao do relator, que assim entendeu, divergências são levantadas. A aplicação dos modelos ao caso permite notar pragmaticamente muitos dos apontamentos e objeções teóricas apontadas nos dois capítulos iniciais.

O segundo caso é o Habeas Corpus n ${ }^{\circ}$ 82.424-2/RS, conhecido como Caso Ellwanger, por ser o paciente no caso Siegfried Ellwanger Castan, um editor e escritor de obras de conteúdo antissemita que fora condenado pelo Tribunal de Justiça do Rio Grande de Sul, decisão essa mantida pelo Superior Tribunal de Justiça, por ter escrito e publicado obras racistas, sendo que a Constituição Federal em seu Art. 5\%, inciso XLII prevê a imprescritibilidade do crime de racismo.

O caso revelou ampla discussão acerca da amplitude semântica do termo racismo, se abrangente ou não do antissemitismo, bem como, identificou-se - embora não o tenham feito todos os julgadores - o conflito de princípios entre liberdade de expressão de Ellwanger e a dignidade de judeus afetada por suas opiniões ofensivas. Também neste caso, a aplicação dos métodos e modelos auxilia na visualização das objeções teóricas e na percepção das dificuldades na apreciação da atuação jurisdicional. 


\section{MÉTODOS JURÍDICOS}

\subsection{COLOCAÇÃO DO PROBLEMA}

Um dos problemas que se enfrenta na prática jurisdicional é a dificuldade no fazer concreto, mesmo com cânones metodológicos ou interpretativos que, na prática, não sanam as dúvidas e não são asseguradamente postos em funcionamento ${ }^{1-2}$.

A posposta subsuntiva tradicional postula a aplicação do Direito de forma dedutiva, tomando-se a norma como premissa maior, o caso como premissa menor que se subsume à proposição jurídica, na qual está indicada a solução jurídica tendo-se em vista os operadores deônticos: permitido, proibido e obrigatório. Assim, a racionalidade da decisão tomada está baseada na fundamentação legal da decisão, dada a premissa do legislador racional.

Não obstante, a questão que se coloca é quanto à racionalidade da decisão judicial em casos em que a solução não está cabalmente predeterminada no ordenamento jurídico e em que o juiz tem de recorrer a mecanismos outros como a ponderação de princípios que eventualmente estejam em conflito concreto.

A preocupação não é, contudo, nem com a metodologia enquanto conjunto de cânones que levem a uma decisão correta ou verdadeira - até porque não se adota aqui o compromisso com tais valores, verdade e correção -, nem de se diferenciar entre métodos e modelos, o que seria tarefa demasiado complexa para a abordagem assaz restrita que aqui se pretende.

A proposta volta-se, então, à questão da racionalidade de decisões judiciais em casos cuja solução é considerada difícil, ou mais especificamente em como nesses casos, em que há a necessidade de se ponderarem princípios conflitantes, a decisão é tomada sem que, com isso, ceife-se o princípio da legalidade, resvalando-se em subjetividade e arbitrariedade, ou

\footnotetext{
1 "Como aponta Alexy, no início de sua Teoria da argumentação jurídica, os estudiosos parecem concordar apenas sobre a ausência de um paradigma, sobre a impossibilidade de se pensar a atividade jurisdicional como mera subsunção do caso à norma. No mais, seja entre teóricos, seja na realidade dos julgamentos, há uma profusão de estilos de julgar e de reflexões sobre tal atividade, sem que se possa dizer, definitivamente, qual delas é a correta". RODRIGUEZ, José Rodrigo. "Quanto terá sido o óbvio...": o debate sobre o formalismo em textos escolhidos (Prefácio). IN: RODRIGUEZ, José Rodrigo (Org.). A Justificação do Formalismo Jurídico textos em debate. São Paulo: Saraiva, 2011, p. 7-11, p. 7.

${ }^{2} \mathrm{O}$ mesmo autor expõe um caso fático da angústia do julgador, seu próprio pai, na busca das soluções aos casos em julgamento, alertando para o fato de que há variação nas interpretações pelas diferenças entre os próprios intérpretes, daí porque propõe que se lance luz sobre o sujeito da interpretação: "a subjetividade irá sempre aflorar, seja para conformar-se com a tradição, seja para dar novos contornos a deduções rigorosamente formalistas, seja para variar o peso dos princípios em conflito". RODRIGUEZ, José Rodrigo. Controlar a profusão de sentidos: a hermenêutica jurídica como negação do subjetivo. In: BOUCAULT, Carlos Eduardo de Abreu; RODRIGUEZ, José Rodrigo. Hermenêutica Plural: possibilidades jusfilosóficas em contextos imperfeitos. São Paulo: Martins Fontes, 2005, p. 277-307, p. 297.
} 
seja, como sanar a "imponderabilidade" entre a ponderação de princípios e a vinculação à lei, como corolário do Estado de Direito democrático. Esse aparente paradoxo é bem ilustrado pelo depoimento do jurista Eros $\mathrm{Grau}^{3}$ após vivência como Ministro do Supremo Tribunal Federal:

\begin{abstract}
Juízes, especialmente os chamados juízes constitucionais, lançam mão intensamente da técnica da ponderação entre princípios quando diante do que a doutrina qualifica como conflito entre direitos fundamentais. Como, contudo, inexiste no sistema jurídico, qualquer regra ou princípio a orientá-los a propósito de qual dos princípios, no conflito entre eles, deve ser privilegiado, essa técnica é praticada à margem do sistema, subjetivamente, de modo discricionário, perigosamente. A opção por um ou outro é determinada subjetivamente, porém a partir das pré-compreensões de cada juiz, no quadro de determinadas ideologias. Ou adotam conscientemente certa posição jurídico-teórica, ou atuam à mercê dos que detém [sic] o poder e do espírito de seu tempo, inconscientes dos efeitos de suas decisões, em uma espécie de "vôo [sic] cego", na expressão de Rüthers [2005:233]. Em ambos os casos essas escolhas são perigosas. No primeiro porque a posição jurídico-teórica não pode ser a nossa; no segundo porque se transformam, esses juízes, em instrumentos dos detentores do poder. São sempre, não obstante, escolhas submetidas a reflexões dramáticas. Eu o sei porque não gozo mais do benefício de ser somente um teórico do direito, de não estar vinculado pelo dever de tomar decisões que serão, em qualquer situação, trágicas para os alcançados por elas. Por que eu? - tenho me perguntado tantas vezes, diante de problemas jurídicos concretos. Quem me outorgou legitimidade para decidir? Toda decisão jurídica é dramática se o juiz não se limitar ao exercício de práticas meramente burocráticas, como um amanuense mediocremente bem comportado. [grifos nossos].
\end{abstract}

A colocação demonstra a dificuldade de se realizar a ponderação de princípios, quando necessária, sem a existência de pautas legais estritas, que assegurariam racionalidade da decisão pela pressuposição, ainda que contrafática, do legislador racional. Ou seja, se houver incompatibilidade entre ponderação e vinculação à lei, o que asseguraria racionalidade às decisões resultantes de ponderação de princípios conflitantes? Ou, mais propriamente, uma pergunta anterior: há de fato "imponderabilidade" entre ponderação e vinculação à lei? Se houver, é sanável?

Essa é a tônica que perpassa o exercício teórico aqui desenvolvido. Começa-se pelo método subsuntivo como denominado o método dedutivo na seara jurídica, considerado como método positivista por excelência, uma vez que se o propunha como garantia de certeza e segurança jurídica, embora hodiernamente se coloque em dúvida essa presunção: a subsunção já não parece tão mecânica e simples como se supusera.

\footnotetext{
${ }^{3}$ GRAU, Eros Roberto. Ensaio e Discurso sobre a Interpretação/Aplicação do Direito. 5. ed. rev. e ampl. São Paulo: Malheiros, 2009, p. 286.
} 
Por outro lado, as Constituições democráticas têm inseridos na categoria de direitos constitucionais princípios - e aqui se parte da presunção da distinção entre princípios e regras, a despeito das divergências sobre o tema, não havendo, assim, compromisso quanto à discussão sobre essa premissa ${ }^{4}$ - cuja solução, via de regra, não permite direta subsunção: é preciso antes resolver o conflito de princípios, e o método apontado para essa tarefa é o da ponderação.

O constrangimento que surge, portanto, é de que se não há diretrizes objetivas sobre a atribuição de pesos que leve ao resultado pela preponderância de um dos princípios em conflito, não haveria a racionalidade decisória que a fundamentação legal asseguraria. Não obstante, o modelo coerentista poderia, em certo viés não unânime nas linhas coerentistas, ser meio de se justificar as decisões judiciais à luz do Direito, podendo potencialmente sanar essa aparente incompatibilidade entre ponderação e vinculação à lei.

O que será assunto reservado ao segundo capítulo do trabalho, culminando no terceiro capítulo, na aplicação dos métodos e modelos a duas decisões prolatadas pelo Supremo Tribunal Federal (STF) em casos de conflito de princípios, o que permite uma aferição concreta e pontual da atuação dessa Corte nesse tipo de casos. Ou seja, não se fará inferência sobre a atuação jurisdicional do STF de modo generalizado, como Corte constitucional, senão especificamente nos casos estudados.

\footnotetext{
${ }^{4}$ Conforme se nota na seção 2.1, as distinções traçadas por Alexy e Dworkin são bastante semelhantes, distinguindo-se em algumas nuanças. Já na proposta de Humberto Ávila, o modo de aplicação deixa de ser meio de distinção, posto que se afasta da pressuposição dos demais autores de que regras se aplicam no molde tudo ou nada e apenas princípios por ponderação: "Com efeito, a ponderação não é método privativo de aplicação dos princípios. A ponderação ou balanceamento (weighing and balancing, Abwägung), enquanto sopesamento de razões e contra-razões [sic]... também pode estar presente no caso de dispositivos hipoteticamente formulados, cuja aplicação é preliminarmente havida como automática (no caso de regras, consoante o critério aqui investigado) [...] É preciso, pois, aperfeiçoar o entendimento de que o conflito entre regras é um conflito necessariamente abstrato, e que quando duas regras entram em conflito deve-se declarar a invalidade de uma delas ou abrir uma exceção. Trata-se de uma qualidade contingente; não necessária. Em segundo lugar, as regras também podem ter seu conteúdo preliminar de sentido superado por razões contrárias, mediante um processo de ponderação de razões. Ademais, isso ocorre nas hipóteses de relação entre a regra e suas exceções" ÁVILA, Humberto. Teoria dos Princípios - da definição à aplicação dos princípios jurídicos. 4. ed. ver. 3. tir. São Paulo: Malheiros: 2005, p. 44-45.
} 


\subsection{O MÉTODO DA SUBSUNÇÃO}

\subsubsection{Caracterização do método da subsunção}

A nomenclatura usual para o método dedutivo no Direito é método da subsunção ou subsuntivo. A vantagem de um argumento ou silogismo dedutivo é que a conclusão não inova em relação às premissas, as quais presume-se já contenham uma solução prévia e geral para o conflito. No campo do Direito, a relevância da aplicação subsuntiva estaria na garantia de certeza e segurança jurídicas $^{5-6}$ : as soluções estariam previamente dadas pelo Direito posto, bastando o enquadramento dos fatos (premissa menor) aos fatos (operativos) previstos da norma (premissa maior), na qual estaria predeterminada a solução. A subsunção da premissa menor à premissa maior implicaria a conclusão já prevista.

\footnotetext{
5 A esse respeito, Dimitri Dimoulis lança interessante contraponto: "Por detrás dessa afirmação [de que o positivismo jurídico garante a segurança-previsibilidade jurídica] encontra-se o problema de definição da segurança jurídica. Podemos dar uma definição muito ampla, entendendo-a como imperativo de aplicação da norma em todos os casos por ela abrangidos e de não aplicação nos demais casos. Nessa perspectiva, todas as escolas de pensamento jurídico garantem a segurança jurídica, pois ninguém sugere a violação do direito. Podemos também optar por definir a segurança jurídica de maneira mais restritiva. Nessa visão, seria entendida como imperativo que: a) proíbe as leis retroativas; b) reduz a liberdade discricionária do aplicador; c) impõe a taxatividade na formulação normativa e, eventualmente, d) garante a justiça material, graças à estabilidade e à previsibilidade que propicia. Entendida com base nessas características, a segurança jurídica não está garantida no ordenamento jurídico brasileiro (e em nenhum outro de nosso conhecimento!) e tampouco pode ser defendida pelo positivismo jurídico. Temos para tanto as seguintes razões: Primeiro, entendendo a segurança jurídica como valor (social, econômico e político de estabilidade, previsibilidade, tutela do indivíduo etc.), o positivismo jurídico não possui motivo para considerá-la como prevalecente em relação a outros valores, ideais e formas de organização social. Em muitos casos, a adaptação rápida do direito a novas situações ou a correção de equívocos normativos é muito mais vantajosa, para certos grupos sociais, do que a preservação de antigas normas e interpretações [...] Segundo, analisando a segurança jurídica como elemento do sistema jurídico (como princípio que pertence ao ordenamento jurídico), constatamos que não há garantia positivada e abrangente da segurança jurídica. Certamente na Constituição e nas leis encontraremos garantias pontuais e limitadas da segurança jurídica... Mas não há proclamação de um princípio geral de segurança jurídica... Há também muitas normas vigentes, indicando que o direito positivo não promove a segurança jurídica. Isso se verifica no caso de normas retroativas e quando se concedem amplos poderes discricionários ao julgador. A partir do momento em que, por exemplo, as normas do Estatuto da Criança e do Adolescente devem ser interpretadas de acordo com os critérios dos "fins sociais" da lei, das "exigências do bem comum" ou da condição peculiar das crianças e dos adolescentes (art. $6^{\circ}$ do ECA), como dizer que o direito positivo sempre deseja promover a segurança jurídica? Terceiro, a referência dos teóricos do direito à segurança jurídica objetiva legitimar o ordenamento jurídico vigente, apresentando seu fiel cumprimento como algo desejável porque promoveria a paz, a ordem e a segurança dos direitos. Mas, como veremos, é exatamente isso que o positivismo jurídico não deseja fazer: recusa-se a legitimar certos ordenamentos ou normas jurídicas, exaltando suas virtudes. DIMOULIS, Dimitri. A relevância prática do positivismo jurídico. Revista Brasileira de Estudos Políticos. Belo Horizonte, n. 102, p. 215-253, jan.-jun. 2011, p. 239 et seq.

${ }^{6}$ Também Tércio Sampaio Ferraz Junior coloca o outro viés: “... direito positivado é um direito que pode ser mudado por decisão, o que gera, sem dúvida, certa insegurança com respeito a verdades e princípios reconhecidos, lançados então, para um segundo plano, embora, por outro lado, signifique uma condição importante para melhor adequação do direito à realidade em rápida mutação, como é a de nossos dias". FERRAZ JUNIOR, Tércio Sampaio. A Ciência do Direito. 2. ed. São Paulo: Atlas, 1980, p. 40.
} 
É cediço que a corrente positivista (em sentido lato), já com Comte e Durkheim, adotou como postulado a aplicação às ciências humanas e sociais dos métodos aplicados às ciências naturais e exatas ${ }^{7}$. Consoante Von Wright ${ }^{8}$, um dos dogmas do positivismo era o monismo metodológico, com a propugnação da unidade do método científico, apesar da diversidade de assunto da investigação científica; e o ideal metodológico era o método empírico das ciências naturais exatas, posto que asseguraria objetividade e neutralidade científicas.

Ademais, a explanação científica seria causal ou mecanicista - e não, portanto, teleológica -, ou seja, seria feita mediante subsunção de casos individuais a leis gerais da natureza hipoteticamente assumidas, incluindo a 'natureza humana'. Conforme Carl Hempel', o argumento dedutivo possui a forma seguinte:

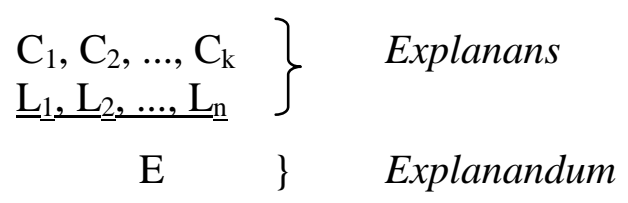

Em que $L_{1}, L_{2}, \ldots, L_{n}$ são leis gerais e $C_{1}, C_{2}, \ldots, C_{k}$ são as assertivas de ocorrências particulares, fatos ou eventos. Conjuntamente, essas premissas formam o explanans. A conclusão E é a sentença de explanandum, que descreve o fenômeno (evento, por exemplo) a ser explicado, também chamado de fenômeno explanandum.

Destarte, um argumento explanatório da forma exposta, subsume dedutivamente o explanandum a "leis de cobertura" (covering laws), de modo que o modelo explicativo representa o modelo de explanação de lei de cobertura ou dedutivo-nomológico (de nomos: lei, norma, regra), ou sinteticamente, dedutivo.

Assim, Hempel e Oppenheim ${ }^{10}$ dividem a explanação em dois constituintes: o explanandum e o explanans. $\mathrm{O}$ explanandum diz respeito à sentença que descreve o fenômeno a ser explicado, não o próprio fenômeno. E o explanans, à classe de sentenças aduzidas para explicar o fenômeno, constando de duas subclasses: uma de sentenças $\left(C_{1}, C_{2}, \ldots, C_{k}\right)$ que

\footnotetext{
${ }^{7}$ Não obstante, como aponta Tercio Sampaio Ferraz Junior, apesar dos caracteres gerais - marcadamente a negação da teleologia -, o termo positivismo (lato sensu) não tem sentido unívoco, o mesmo se podendo dizer quanto ao positivismo jurídico. FERRAZ JUNIOR, Tercio Sampaio. A Ciência do Direito. 2. ed. São Paulo: Atlas, 1980 , p. $30-31$.

${ }^{8}$ VON WRIGHT, Georg Henrik. Explanation and Understanding. London: Routledge \& Kegan Paul, 1971.

${ }^{9}$ HEMPEL, Carl G. Deductive-Nomological vs. Statistical Explanation. Minnesota Studies in the Philosophy of Science, n. 3, p. 98-169, 1962.

${ }^{10}$ HEMPEL, Carl G.; OPPENHEIM, Paul. Studies in the logic of explanation. Philosophy of Science, v. 15, n. 2, p. $135-175$, apr. 1948 , p. 136 et seq.
} 
estabelecem condições antecedentes específicas, e outra, um sistema de sentenças $\left(\mathrm{L}_{1}, \mathrm{~L}_{2}, \ldots\right.$, $\mathrm{L}_{\mathrm{n}}$ ) que representam leis gerais.

As leis implicam que, sempre que as condições do tipo indicado por $\mathrm{C}_{1}, \mathrm{C}_{2}, \ldots, \mathrm{C}_{\mathrm{k}}$ ocorrerem, um evento do tipo descrito em E ocorrerá. Assertivas como $\mathrm{L}_{1}, \mathrm{~L}_{2}, \ldots, \mathrm{L}_{\mathrm{n}}$ são comumente chamadas leis causais ou deterministas. E essa caracterização seria aplicável, segundo os autores, a outras ciências que não apenas às físicas, embora sem a mesma regularidade e precisão de sua aplicação na Física ou Química.

No âmbito do Direito, parte-se da fórmula de que a regra e os fatos implicam a conclusão $(\mathrm{R}+\mathrm{F} \rightarrow \mathrm{C}$ ), entendendo-se por regras as proposições normativas hipotéticas, estipulando que, se certas circunstâncias - ou 'fatos operativos' - advierem, então determinadas consequências se seguem ou devem se seguir ou ser implementadas. O que também poderia ser expresso da seguinte forma: Em qualquer caso, se $p$ então $q^{11}$. Conforme Neil MacCormick ${ }^{12}$, um argumento completo poderia ser expresso simbolicamente como:
(A) Em qualquer caso, se $p$ então $q$.
(B) No caso atual $p$.
(C) $\therefore$, no caso presente, $q$.

Ou seja, em qualquer caso em que se der $p$, deve ocorrer a consequência $q$. Se no caso presente ocorrer $p$, deve levar à consequência $q$. Isso demonstra que a conclusão do argumento dedutivo é implicada por outra proposição ou proposições, as 'premissas' do argumento. De modo que um argumento dedutivo é válido se, qualquer que seja o conteúdo das premissas e a conclusão, sua forma é tal que suas premissas implicam ou abarcam a conclusão.

Disso se nota que a validade do argumento não se afere levando-se em consideração o conteúdo das proposições. Como se fala de validade formal, sua validade lógica não garante a verdade de sua conclusão, posto que nada se estabelece sobre a verdade das premissas, o que seria uma questão empírica.

No caso do julgador, presume-se que ele conheça a proposição de Direito (premissa maior) com a qual ele deve trabalhar em certo caso, expressa no brocardo jura novit curia. Ao se deparar com premissas menores, assertivas de fatos, ante a proposição 'Se $p$, então $q$ ', se

\footnotetext{
${ }^{11}$ Naturalmente que, em linguagem natural, nem todas as regras jurídicas ou, quiçá, uma minoria expresse-se explicitamente dessa forma. Veja-se, por exemplo, o Art. 121 do Código Penal brasileiro, in verbis: "Matar alguém: Pena - reclusão, de 6 (seis) a 20 (vinte) anos". O que não impede que seja extraída a norma hipotética: "se matar, será condenado a pena de seis a vinte anos de reclusão". No caso concreto, aferindo-se que A matou $\mathrm{B}$, logo, A será condenado à pena em quantum pautado por tais margens.

${ }^{12}$ MACCORMICK, Neil. Legal reasoning and legal theory. New York: Oxford University Press, 2003, passim.
} 
ele identificar como proposição de fato o que implique ' $p$ ', estará comprometido com a proposição $q$ como forma de conclusão.

No entanto, esse método de trabalho não capta diversos problemas que a prática jurídica pode implicar: os problemas éticos na aplicação de determinadas normas a certos casos; a possibilidade de algum caso não constar de solução previamente dada (problema da lacuna normativa) ou de a solução resultar da desconsideração de alguma questão que alteraria a regulamentação dada pelo legislador (lacuna axiológica).

Para não se falar da situação em que o julgador discorde da conclusão $q$ no contexto de um caso particular, podendo simplesmente dizer que não considera certos fatos provados, e consequentemente não é o caso de $p$ ou, a contrario sensu, se ele deseja alcançar a conclusão $q$, diria que considera $p$ verdadeiro no caso sub judice $e^{13}$. Embora, como considera MacCormick, o fato de que os juízes poderiam se comportar assim seja óbvio; que o façam, às vezes, seja possível e mesmo provável. Mas que sempre se comportem assim seria extremamente improvável, especialmente pela obrigatoriedade de justificação jurídica ${ }^{14}$ que seria de difícil alcance em alguns casos em que se dê tal comportamento ${ }^{15}$.

Assim, como conclui MacCormick, se o processo de justificação jurídica pode, às vezes, ser puramente dedutivo e lógico, isso não significa que sempre o seja. Ademais, a subsunção, embora pareça um método de aplicação simples e objetiva, nem sempre é tão mecânico e destituído de maior complexidade, posto que a identificação das premissas pode não ser de fácil alcance, seja quanto à premissa maior pela vagueza da própria linguagem que dificulte a cabal aferição de quais circunstâncias realmente se enquadram nos fatos operativos da norma; seja pela dificuldade, característica dos problemas de prova, na aferição da premissa menor.

\footnotetext{
${ }^{13}$ MACCORMICK, Neil. Legal reasoning and legal theory. New York: Oxford University Press, 2003.

${ }^{14}$ MacCormick fala não apenas da justificação jurídica, mas também da justificação legal, o que não implica, contudo, mecanicismo: "Especially within a codified system of law, it may be deemed necessary to refer every dispute and decision thereon to some article or articles of a Code. If the Code is considered as comprehensively covering the whole field of law, then no decision can be held justified unless it is subsumed under an article of written law - on some interpretation of that article. The very fact of the comprehensiveness of the Code entails relatively high generality in the terms of its articles, and hence relatively wide latitudes of interpretation and leeways of choice. So it should not be thought that reasoning and argumentation in a codified system is always or necessarily 'formalistic' or mechanical'. MACCORMICK, Neil. Legal Reasoning and Legal Theory. New York: Oxford University Press, 2003, p. 68.

15 "A judge knows the proposition of Law with which he has to work in a given case [...] He can simply say that he does not find certain facts proven, and therefore $p$ is not the case. Equally, if he is desirous of reaching the conclusion $q$, he need only say that he finds $p$ true in the instant case. So, logical though his argument will be on the face of it, it is no more than rationalization, since he determined its course by way in which he chose to 'find' the facts... That judges could so behave is obvious. That they do sometimes so behave is possible, indeed, likely. That they always so behave is on the face of it extremely unlikely". MACCORMICK, Neil. Legal Reasoning and Legal Theory. New York: Oxford University Press, 2003, p. 36.
} 


\subsubsection{Desafios ao Método da Subsunção}

Carl Hempel, ao tratar do método dedutivo-nomológico ou dedutivo propondo-o não apenas às ciências naturais e exatas, mas também às humanas e sociais, não deixou de considerar as objeções a essa aplicação. Em artigo conjunto com Oppenheim, os autores ${ }^{16}$ expõem que os motivos para a oposição seriam a ideia de que eventos envolvendo atividades humanas individuais ou em grupos seria caracterizada por unicidade e irrepetibilidade, o que as tornaria inacessíveis à explanação causal, porque esta pressupõe repetibilidade dos fenômenos sob consideração - tanto assim que se expressam em leis gerais -, de modo que o método experimental seria inaplicável na psicologia e ciências sociais.

Um segundo argumento contrário seria de que o estabelecimento de generalizações científicas e, pois, princípios explanatórios para o comportamento humano seria impossível, pois as reações de um indivíduo em certa situação dependem não apenas da situação, como também da história prévia dos indivíduos. E um terceiro argumento seria de que a explanação de qualquer fenômeno envolvendo comportamento intencional exige referência a motivações e, pois, análise teleológica, em vez de causal.

Quanto ao primeiro argumento, Hempel responde que reflete uma incompreensão do caráter lógico da explanação causal, uma vez que todo evento individual, mesmo nas ciências físicas, seria único no sentido de que, com todas as suas características peculiares, não se repetiria. No obstante, isso não seria impeditivo de que os eventos individuais pudessem se conformar a leis gerais do tipo causal, sendo explicados por elas.

E embora não negue que muitas das explicações, frequentemente incompletas, que são oferecidas para as ações humanas - como a ato de julgar - envolvem referência a objetivos e motivos, Hempel questiona se isso as tornaria essencialmente diferentes de explicações causais da Física e Química, uma vez que não haveria nenhuma diferença formal entre explicação causal e motivacional. Até mesmo porque os fatores determinantes aduzidos em explicações físicas também são, para ele, frequentemente inacessíveis à observação direta; não haveria nenhuma diferença, pois, entre a explicação causal e a motivacional ${ }^{17}$.

\footnotetext{
${ }^{16}$ HEMPEL, Carl G.; OPPENHEIM, Paul. Studies in the logic of explanation. Philosophy of Science, v. 15, n. 2, p. 135-175, apr. 1948, p. 142 et seq.

${ }^{17}$ Hempel e Oppenheim concluem: "The decisive requirement for every sound explanation remains that it subsume the explanandum under general laws". HEMPEL, Carl G.; OPPENHEIM, Paul. Studies in the logic of explanation. Philosophy of Science, v. 15, n. 2, p. 135-175, apr. 1948, p. 146.
} 
Como expõem Alchourrón e Bulygin ${ }^{18}$ - cujo desdobramento mais detalhado do método dedutivo no Direito é encontrado na obra Normative Systems -, o traço mais característico da atividade científica é a preocupação com a explicação racional. No caso da conduta humana, a pergunta sobre o porquê de uma ação poderia assumir duas formas distintas: a razão para alguém ter agido de certa maneira, os fatos que determinaram causalmente sua conduta - o que seria objeto de ciências empíricas como psicologia e sociologia; ou o porquê da qualificação deôntica de uma conduta, não interessando, pois, a conduta em si ou por que alguém tomou certa atitude, mas por que a ação é obrigatória, permitida ou proibida, o que seria uma forma especial de explicação racional: a justificação normativa, objeto de ciências normativas como o Direito ou a ética.

Ainda segundo os autores, pode-se justificar normativamente a qualificação deôntica de uma conduta por meio de um sistema normativo, a partir do qual se infere o status deôntico da conduta. O mecanismo de explicação ou justificação seria, portanto, a demonstração de que certo fenômeno ou conduta é dedutível de um sistema normativo que contém leis gerais e condicionantes do caso ${ }^{19}$.

Para a realização da sistematização, os autores propõem uma sequência de passos: primeiramente deve-se identificar o problema para o qual se procura a regulamentação, o que se faz determinando-se o universo de ações (UA) ou condutas e o universo de discurso (UD) que diz repeito à situação ou às circunstâncias envolvidas; ambos, universo do discurso e universo de ações, determinam o âmbito normativo do problema. Também se levanta o universo de propriedades (UP), relativo às propriedades relevantes, ou seja, as propriedades que podem alterar a solução normativa do caso uma vez presentes ou ausentes.

Cumpre para elucidar o modelo, trazer a lume o problema normativo exposto pelos autores relativamente à reivindicação de coisas imóveis contra terceiros possuidores. $\mathrm{O}$ problema ocorre quando o alienante não é proprietário e aliena o bem a título gratuito ou oneroso para um terceiro. A questão é: em que circunstâncias o adquirente (o terceiro possuidor) está obrigado a restituir o imóvel ou quando pode retê-lo.

Nesse caso, o UD é definido pela alienação de um imóvel alheio, ou seja, uma situação em que o alienante transfere ao adquirentes a posse de um imóvel de outrem. O UA restringe-

\footnotetext{
${ }^{18}$ ALCHOURRÓN, C.; BULYGIN, E. Introducción a la metodología de las ciencias jurídicas e sociales. Buenos Aires: Astrea, 1971.

${ }^{19}$ Segundo Karl Engish, "o juiz, perante o seu cargo (função) e a sua consciência, tão-só poderá sentir-se justificado quando a sua decisão também possa ser fundada na lei, o que significa, ser dela deduzida. Neste ponto de vista, a descoberta e a fundamentação da decisão não são procedimentos opostos. A tarefa que o juiz tem perante si é esta: descoberta duma decisão (solução) fundamentada através da lei”. ENGISH, Karl. Introdução ao Pensamento Jurídico. Tradução de J. Baptista Machado. 6. ed. Lisboa: Fundação Calouste Gulbenkian, 1983, p. 85.
} 
se à ação de restituição do imóvel $(\mathrm{R})$, ou seja, o UA $=[\mathrm{R}]$ (o universo de ações refere-se à ação de restituir), esse, portanto, é o âmbito normativo do problema, caracterizado pela conjunção do UD e do UA.

No que diz respeito às propriedades relevantes desse problema normativo, trata-se de questão valorativa, havendo consenso mais ou menos unânime relativamente aos valores, o que implica sua contingência ${ }^{20}$. No problema em caso, são relevantes a boa fé do comprador (BFC), a boa fé do possuidor anterior ou alienante (BFA) e o título oneroso (TO) do ato de alienação.

Presume-se a boa fé em caso de ignorância do fato de que o domínio do imóvel é alheio e, em sua ausência, há má fé ( BF). Simboliza-se também a alienação não onerosa, ou seja, gratuita por $\sim$ TO (sem título oneroso). A definição do universo de casos (UC) está em função do universo de propriedades (UP), segundo a fórmula $2^{\text {n }}$, sendo ' $\mathrm{n}$ ' o número de propriedades relevantes.

Nesse caso, havendo três propriedades relevantes, o número total de casos elementares, ou seja, em que a propriedade esteja presente ou ausente, será igual a oito $\left(2^{3}=\right.$ 8). Na construção da matriz, na coluna da extrema esquerda aparecem os casos possíveis (1-8) e na linha superior o UP. Assim, pode-se montar a seguinte matriz:

\begin{tabular}{|l|l|l|l|}
\cline { 2 - 4 } \multicolumn{1}{c|}{} & BFA & BFC & TO \\
\hline 1 & + & + & + \\
\hline 2 & - & + & + \\
\hline 3 & + & - & + \\
\hline 4 & - & - & + \\
\hline 5 & + & + & - \\
\hline 6 & - & + & - \\
\hline 7 & + & - & - \\
\hline 8 & - & - & - \\
\hline
\end{tabular}

\footnotetext{
20 "Si ciertas propiedades parecen ser totalmente irrelevantes para el problema (como, por ejemplo, el color de la piel del propietario o el tamaño de su nariz), ocurre ello así solamente porque existe um consenso más o menos unánime (en un determinado grupo social) acerca de ciertos valores. Pero esto es un hecho meramente contingente. Una ley que hiciera depender la procedencia de la acción reivindicatoria del color de la piel del propietario nos pareceria violentamente injusta, pero no quedaria com ello excluida la posibilidad de que en otras latitudes (o en otras épocas) tal ley pudiera parecer perfectamente razonable" ALCHOURRÓN, C.; BULYGIN, E. Introducción a la metodología de las ciencias jurídicas e sociales. Buenos Aires: Astrea, 1971, p. 33.
} 
Os sinais + e - são indicativos, respectivamente, da presença e da ausência da propriedade correspondente. Esse conjunto de todos os casos possíveis determina o que se denomina de âmbito fático do modelo. No que diz respeito ao âmbito normativo do problema, ou seja, o caráter deôntico da ação - obrigatório, proibido ou permitido (respectivamente: $\mathrm{O}$, $\mathrm{Ph}, \mathrm{P}$ ), no caso em tela, os conteúdos possíveis do UA são restituir e não restituir ( $\mathrm{R}$ e $\neg \mathrm{R}$, respectivamente).

A ação de restituir será obrigatória quando: for permitido restituir e não permitido, ou proibido, não restituir; será proibida se não for permitido restituir ou permitido não restituir; e facultativa, quando estiver permitido restituir e não restituir. Haverá uma solução maximal sempre que tanto a ação quanto sua omissão (no exemplo, restituir e não restituir) estiverem deonticamente determinadas.

Para a reconstrução do sistema normativo segundo o modelo de matrizes, toma-se como norma o sentido do seguinte enunciado: "Se o adquirente está de má fé, então é obrigado a restituir o imóvel ao proprietário", o que simbolicamente indica: OR/ $\mathrm{BFC}$ (obrigatório restituir se o comprador está de ma fé).

No Código Civil argentino, consoante apontam Alchourrón e Bulygin, o problema delineado está regulado nos Arts. 2.777 e 2.778, baseados no projeto do jurista brasileiro Freitas. Também o Art. 3877, inciso $2^{\circ}$; o Art. 3878, incisos $2^{\circ}$ e $3^{\circ}$ e Art. 3882 disciplinam a matéria. O primeiro dispositivo determina que "compete a reivindicação quando a coisa demandada fosse imóvel... contra o atual possuidor, ainda que a houvesse de boa fé por título oneroso, se a obteve do alienante de má fé”.

Segundo o Art. 3878, “compete a reivindicação, de móvel ou imóvel”, inciso $2^{\circ}$ : “contra o atual possuidor que o houve de má fé do alienante obrigado a restituir ao reivindicante", e inciso $3^{\circ}$ : "contra o atual possuidor, ainda que a houvesse de boa fé do alienante de boa fé, se a obteve por título gratuito". Finalmente, o Art. 3882, inciso $1^{\text {o }}$ dispõe que "não compete a reivindicação, de móvel ou imóvel, contra o possuidor de boa fé que a obteve de alienante de boa fé por título oneroso".

Do que se pode extrair que, quanto ao Art. 3877, inciso $2^{\circ}$, em que se trata de caso de boa fé do comprador, título oneroso e má fé do alienante, a norma permite notar que, muito embora estejam presentes as primeiras propriedades, a última é decisiva no sentido de determinar-se a obrigatoriedade da restituição; assim, havendo má fé do alienante, seria obrigatório restituir (OR/ᄀBFA).

Conforme o Art. 3878 , inciso $2^{\circ}$, a má-fé do comprador é condição suficiente para a reivindicação $(\mathrm{OR} / \neg \mathrm{BFC})$; já no inciso $3^{\circ}$, segundo o qual ainda que haja boa fé de ambas as 
partes é obrigatório restituir caso seja a título gratuito, permite inferir que para a reivindicação ser procedente, basta o título ser gratuito (OR/ᄀ TO).

E o Art. 3882 , inciso $1^{\circ}$ dispõe que a boa fé das partes e o título oneroso excluem a obrigatoriedade da reivindicação, de modo que é não obrigatória, nem proibida, será facultativa $\left(\mathrm{FR} / \mathrm{BFC}^{\wedge} \mathrm{BFA}^{\wedge} \mathrm{TO}\right)$. Pela ordem, tem-se relativamente aos artigos citados, as

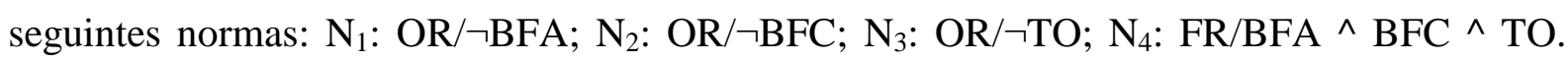
Sendo, portanto o sistema de Freitas composto pelas quatro normas referidas $\left(S=\left\{N_{1}, N_{2}, N_{3}\right.\right.$, $\mathrm{N}_{4}$ \}). O que permite construir a seguinte matriz:

\begin{tabular}{|c|c|c|c|c|}
\hline Norma & $\begin{array}{l}\text { N1 } \\
(\mathrm{OR} / \neg \mathrm{BFA})\end{array}$ & $\begin{array}{l}\mathrm{N} 2 \\
(\mathrm{OR} / \neg \mathrm{BFC})\end{array}$ & N3 (OR/ᄀTO) & $\begin{array}{l}\text { N4 } \\
\text { (FR/BFC.BFA.TO) }\end{array}$ \\
\hline 1. $\mathrm{BFA} \quad \mathrm{BFC}$ TO & & & & FR \\
\hline 2. $\neg \mathrm{BFA} \quad \mathrm{BFC} \quad \mathrm{TO}$ & OR & & & \\
\hline 3. $\mathrm{BFA} \neg \mathrm{BFC}$ TO & & OR & & \\
\hline 4. $\neg \mathrm{BFA} \neg \mathrm{BFC}$ TO & OR & OR & & \\
\hline 5. $\mathrm{BFA} \quad \mathrm{BFC} \neg \mathrm{TO}$ & & & OR & \\
\hline 6. $\neg \mathrm{BFA} \quad \mathrm{BFC} \neg \mathrm{TO}$ & OR & & OR & \\
\hline 7. $\mathrm{BFA} \neg \mathrm{BFC} \neg \mathrm{TO}$ & & OR & OR & \\
\hline 8. $\neg \mathrm{BFA} \neg \mathrm{BFC} \neg \mathrm{TO}$ & OR & OR & OR & \\
\hline
\end{tabular}

A reconstrução desse sistema, por meio da matriz acima, permite notar que o sistema é completo, uma vez que todos os casos estão solucionados pelo sistema e não há, pois, nenhum caso que não tenha solução normativa, o que configuraria um caso de lacuna normativa; e, ainda, que este é redundante ou tautológico nos casos 4, 6, 7, 8, já que diferentes normas dão aos casos a mesma solução (se fossem soluções incompatíveis para os mesmos casos, o sistema seria incoerente $)^{21}$.

Já quanto aos Artigos 2777 e 2778 do Código Civil argentino, acima referidos, a solução é diferente, embora baseados no sistema de Freitas, e resume-se este sistema a apenas duas normas $\left(\mathrm{S}_{2}=\mathrm{N}_{5}\right.$ e $\left.\mathrm{N}_{6}\right)$. Segundo o Art. $2777\left(\mathrm{~N}_{5}\right)$, “compete também [a reivindicação] contra o atual possuidor de boa fé que a obteve por título oneroso de um alienante de má-fé" (que modifica o Art. 3877, inciso $3^{\circ}$, em razão da supressão de sua ressalva, 'ainda que’).

\footnotetext{
${ }^{21}$ Não se tratará aqui dos mecanismos para solucionar a redundância e das limitações desses meios, muito embora tenham sido explanados pelos autores.
} 
E o Art. $2778\left(\mathrm{~N}_{6}\right)$ dispõe: "Seja a coisa móvel ou imóvel, a reivindicação compete... contra o atual possuidor, ainda que de boa fé, se a houve por título gratuito" (o que reproduz o Art. 3878, inciso $3^{\circ}$ ). Do que se depreende que, consoante o primeiro dispositivo, será obrigatório restituir se houver boa fé do adquirente, título oneroso e má-fé do alienante

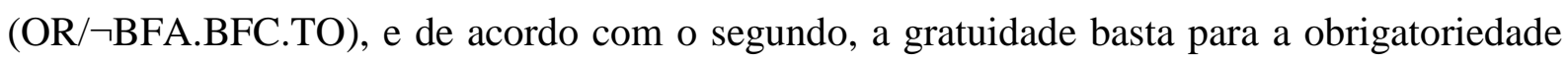
de restituir (OR/ᄀTO). Esse sistema normativo é formado pelas normas referidas $\left(\mathrm{S}_{2}=\left\{\mathrm{N}_{4}\right.\right.$; $\mathrm{N}_{5}$ ). Reconstruindo-o: tem-se

\begin{tabular}{|c|c|c|}
\hline Norma & $\begin{array}{l}\mathrm{N} 4 \\
\text { (OR/ᄀBFA.BFC.TO) }\end{array}$ & $\begin{array}{l}\text { N5 } \\
(\mathrm{OR} / \neg \mathrm{TO})\end{array}$ \\
\hline 1. BFA BFC $\mathrm{TO}$ & & \\
\hline 2. $\neg \mathrm{BFA} \quad \mathrm{BFC} \quad \mathrm{TO}$ & OR & \\
\hline 3. $\mathrm{BFA} \neg \mathrm{BFC}$ TO & & \\
\hline 4. $\neg \mathrm{BFA} \neg \mathrm{BFC}$ ТO & & \\
\hline 5. $\mathrm{BFA}$ BFC $\neg \mathrm{TO}$ & & OR \\
\hline 6. $\neg \mathrm{BFA} \quad \mathrm{BFC} \neg \mathrm{TO}$ & & OR \\
\hline 7. $\mathrm{BFA} \neg \mathrm{BFC} \neg \mathrm{TO}$ & & OR \\
\hline 8. $\neg \mathrm{BFA} \neg \mathrm{BFC} \neg \mathrm{TO}$ & & OR \\
\hline
\end{tabular}

Note-se que este sistema apresenta lacuna normativa para os casos 1, 3 e 4, pois nesses casos o sistema não apresenta a solução normativa para o problema. Isso denota que, se por um lado, a reconstrução do sistema normativo facilita a subsunção do caso à norma posta pelo legislador, por outro, evidencia a limitação do modelo subsuntivo na solução de casos de lacuna tanto normativa quanto axiológica, entendendo-se pela primeira a situação em que o sistema normativo não determina nenhuma solução para o caso e, quanto às lacunas axiológicas, muito embora o sistema determine a solução, o legislador deixou de considerar hipóteses relevantes para o caso que, por serem relevantes, teriam influído na regulamentação $\operatorname{dada}^{22-23}$.

\footnotetext{
${ }^{22}$ Como pontuam Alchourrón e Bulygin: "Pero no toda solución injusta o mala supone una laguna; los juristas hablan de lagunas - en el sentido que tratamos de caracterizar- cuando la solución es inadecuada porque el legislador no tuvo en cuenta una distinción que debía haber tomado en cuenta. [...] Si el legislador ha considerado todas las circunstancias (que deben ser) relevantes del caso y después lo solucionó mal (injustamente), el resultado es un defecto axiológico del sistema, pero no una laguna. Para poder hablar de una laguna axiológica, es necesario que haya una discrepancia entre la tesis de relevancia del sistema y la hipótesis de relevancia (para el UA)... Las soluciones pueden ser injustas, aunque se hayan tomado en cuenta todas las
} 
O modelo de matrizes ainda permite evidenciar a incoerência do sistema em razão de inconsistências normativas, ou seja, a determinação de soluções incompatíveis para o mesmo caso, o que se nota concretamente e não abstratamente ${ }^{24}$. Segundo Karl Engish ${ }^{25}$, a solução para tais inconsistências poderia ser encontrada por meio dos tradicionais critérios de solução de antinomias, segundo os quais a norma especial tem precedência sobre a geral (lex specialis derogat legi generali), a norma superior tem primazia em relação à inferior (lex superior derogat legi inferiori), e a norma posterior prevalece em relação à norma anterior (lex posterior derogat legi priori). Embora surja a possibilidade e problema do conflito entre tais critérios ou inexistência de critérios para uma determinada solução ${ }^{26}$.

Ainda outras dificuldades para a aplicação do método subsuntivo na solução dos casos são apontadas por Engish, entre as quais o uso de conceitos indeterminados, de conceitos normativos, de poder discricionário, de cláusulas gerais, as próprias lacunas, as contradições de princípios, além das já citadas inconsistências normativas. Elementos que implicam

\footnotetext{
distinciones pertinentes. Pero en esos casos no hay lagunas axiológicas. ALCHOURRÓN, C.; BULYGIN, E. Introducción a la metodología de las ciencias jurídicas e sociales. Buenos Aires: Astrea, 1971, p. 159-161.

${ }^{23}$ O que também se distingue, pois, do que Karl Engish chama de lacuna político-jurídica: “... a inexistência da regulamentação em causa pode corresponder a um plano do legislador ou da lei, e então não representa uma 'lacuna' que tenha de se apresentar sempre como uma 'deficiência' que estamos autorizados a superar. Uma tal inexistência planeada de certa regulamentação (propriamente uma regulamentação negativa) surge quando uma conduta, cuja punibilidade nós talvez aguardemos, 'consciente e deliberadamente' não é declarada como punível pelo Direito positivo. Se esta impunidade nos cai mal, podemos falar na verdade de uma 'lacuna políticojurídica', de uma 'lacuna crítica', de uma 'lacuna imprópria', quer dizer, de uma lacuna do ponto de vista de um futuro Direito mais perfeito 'de lege ferenda'); não, porém, de uma lacuna autêntica e própria, quer dizer, duma lacuna no Direito vigente ('de lege lata'). Uma lacuna de lege ferenda apenas pode motivar o poder legislativo a uma reforma do Direito, mas não o juiz a um preenchimento da dita lacuna. A colmatação judicial de lacunas pressupõe uma lacuna de lege lata". ENGISH, Karl. Introdução ao Pensamento Jurídico. Tradução de J. Baptista Machado. 6. ed. Lisboa: Fundação Calouste Gulbenkian, 1983, p. 281-282.

${ }^{24} \mathrm{Tal}$ é, por exemplo, um sistema normativo que conste de duas normas $\mathrm{N}_{1}$ e $\mathrm{N}_{2}$ que, respectivamente, determinem que: $\mathrm{N}_{1}$ - "É proibido passar no semáforo vermelho"; $\mathrm{N}_{2}$ - "É proibido parar em zona militar". Aparentemente, não há qualquer conflito normativo entre as normas desse sistema. Não obstante, em um caso em que haja um semáforo em zona militar e, estando vermelho, não haveria como obedecer ao sistema, uma vez que, segundo $\mathrm{N}_{1}$ é obrigatório parar $(\mathrm{OP})$, já segundo $\mathrm{N}_{2}(\mathrm{O} \neg \mathrm{P})$ é obrigatório não parar. Qualquer conduta adotada consistirá em infração.

${ }^{25}$ ENGISH, Karl. Introdução ao Pensamento Jurídico. Tradução de J. Baptista Machado. 6. ed. Lisboa: Fundação Calouste Gulbenkian, 1983, p. 313-314.

${ }^{26}$ Norberto Bobbio propõe que em caso de conflito entre o critério hierárquico e o cronológico, o primeiro deve prevalecer; entre o critério de especialidade e o cronológico, também há prevalência do primeiro. Já no caso de conflito entre o critério hierárquico e o de especialidade há divergência doutrinária e sugere-se o uso do critério cronológico para se definir qual deles deverá prevalecer. O autor ainda cita como exemplo de situação de inaplicabilidade desses critérios o caso de normas contemporâneas, paritárias e gerais, propondo, neste caso, o critério Lex favorabilis sobre Lex odiosa, mas aqui ainda pode-se questionar: critério favorável para quem, havendo, por exemplo, no âmbito cível - já que no penal poder-se-ia recorrer ao brocardo in dubio pro reo mais de uma parte. Vide: BOBBIO, Norberto. O Positivismo Jurídico: Lições de Filosofia do Direito. Tradução e notas de Márcio Pugliesi, Edson Brini, Carlos E. Rodrigues. São Paulo: Ícone, 1995, p. 205-206.
} 
dificuldades na obtenção da premissa maior à qual se possa subsumir o caso em julgamento. Até porque, conforme Engish ${ }^{27}$ :

Uma primeira e mais complicada tarefa de que o jurista tem de se desempenhar para obter a partir da lei a premissa maior jurídica consiste em reconduzir a um todo unitário os elementos ou partes de um pensamento jurídico-normativo completo que, por razões "técnicas", se encontram [sic] dispersas para não dizer violentamente separadas.

Ou seja, postula-se que as premissas maiores jurídicas devam de ser elaboradas a partir da consideração de todo o Código ou mesmo de outros Códigos ou leis. Ocorre, contudo, que, além de essa tarefa ser de aplicação pragmaticamente difícil, a construção da premissa maior resulta da tarefa de interpretação, para se obter o alcance (extensão) dos conceitos jurídicos, bem como sua definição que indique seu conteúdo ${ }^{28}$. Havendo a possibilidade de os tradicionais métodos de interpretação, gramatical, lógico-sistemático, histórico não conduzirem a um resultado certo ${ }^{29}$. Especialmente quando se inserem nas normas os conceitos supracitados que dão mais espaço ao julgador em sua delimitação.

Quanto aos conceitos indeterminados, trata-se de conceitos de conteúdo e extensão incertos, dada sua vagueza ${ }^{30-31}$. No direito pátrio tem-se, por exemplo, expressões como

${ }^{27}$ ENGISH, Karl. Introdução ao Pensamento Jurídico. Tradução de J. Baptista Machado. 6. ed. Lisboa: Fundação Calouste Gulbenkian, 1983, p. 116.

${ }^{28}$ Vale citar a colocação de Tercio Sampaio Ferraz Junior de que "O jurista (o advogado, o procurador, o juiz, o profissional do direito) sabe que existem alguns limites que não deve ultrapassar: a possibilidade de interpretação é muito ampla, mas há um limite perceptível, quando se inova, o que exige desdobrado esforço argumentativo de convencimento persuasivo. Por que, não obstante, soa estranho o epíteto: racional? Agora estou falando em termos jurídicos e não em termos da linguagem comum, aquela da nossa conversação comum. Eu me recordo de um colega, amigo meu que é criminalista e que tinha um cliente que foi apanhado com 400 quilos de maconha. E ele, perante o juiz, disse o seguinte: 'o meu cliente, ele fuma maconha, a maconha encontrada com ele é pra consumo próprio’. Aí houve um sorriso óbvio, não só nos lábios do juiz, mas no de todos: quatrocentos quilos para consumo próprio?... Diante do que argumentou o advogado: 'Preciso esclarecer que meu cliente é um homem crente, que acredita que o corpo dele morre, mas não a alma, que passa a um outro corpo após a morte, enfim, ele acredita na transmigração. Portanto, ao adquirir $400 \mathrm{~kg}$ de maconha, ele não pensou só nessa vida, mas fez uma provisão para suas outras vidas [...]' ... Não obstante, é evidente que essa era uma argumentação, cuja interpretação da lei (porte de maconha para uso próprio ou tráfico?) batia num limite. Qual limite? No fundo é disso que se trata quando se está tentando ver se existe algum grau de objetividade na interpretação. Não vou entrar nessa discussão, isto é, que é objetividade? Mas, sem dúvida, a buscada objetividade tem a ver com essa figura, a figura do legislador racional. O legislador racional, dentre outras regras a que se submete e que temos de pressupor, prescreve que: ele não estabelece coisas absurdas”. FERRAZ JUNIOR, Tércio Sampaio. A Hipótese do Legislador Racional e a Noção de Justiça. In: BARBIERI, Catarina; MACEDO Jr., Ronaldo Porto. Cadernos Direito GV: Interpretação, desenvolvimento e instituições interpretação e objetividade; usos e abusos nas interpretações judiciais; interpretação, política e função. São Paulo, v. 6, n. 3, p. 21-41, mai.2009, p. 30.

29 ENGISH, Karl. Introdução ao Pensamento Jurídico. Tradução de J. Baptista Machado. 6. ed. Lisboa: Fundação Calouste Gulbenkian, 1983.

${ }^{30}$ Segundo Tércio Sampaio Ferraz Junior, no caso de conceitos indeterminados, "supõe-se que uma clarificação, por parte do decididor, no momento de aplicação da norma, seja necessária. É como se o legislador, cônscio da generalidade dos termos que tem de usar e da impossibilidade de particularizá-los ele próprio sob risco de uma 
"repouso noturno", "ruído excessivo" e "perigo iminente"32 -33. Há ainda o exemplo da súmula vinculante $\mathrm{n}^{\mathrm{o}} 11^{34}$, segundo a qual:

Só é lícito o uso de algemas em casos de resistência e de fundado receio de fuga ou de perigo à integridade física própria ou alheia, por parte do preso ou de terceiros, justificada a excepcionalidade por escrito, sob pena de responsabilidade disciplinar, civil e penal do agente ou da autoridade e de nulidade da prisão ou do ato processual a que se refere, sem prejuízo da responsabilidade civil do Estado.

Não há no caso a determinação do que caracteriza "fundado receio de fuga", ficando a cargo da autoridade competente essa definição. Além disso, segundo Engish, "os conceitos, indeterminados podem aparecer nas normas jurídicas não só na chamada 'hipótese' como ainda na "estatuição",35. O exemplo que o autor dá é do Código de Processo Penal alemão que atribui no seu $\$ 231$ prerrogativa ao juiz para determinar “as medidas apropriadas" em relação ao acusado, sem a definição ou exemplificação de em que consistiriam tais medidas.

No concernente aos conceitos normativos, são conceitos valorativamente carregados, não se podendo determinar de antemão sua abrangência. Tem-se a esse respeito normas relativas à honra, à dignidade, que envolvem uma valoração genérica a ser concretizada em casos sob julgamento ${ }^{36}$. Como nota Tercio Sampaio Ferraz Junior ${ }^{37}$

O problema está, justamente, em aceitar que, nestes casos, o que conta é a concepção pessoal do aplicador, o modo como ele concebe o objeto da decisão, conjugada com o princípio da neutralidade da posição do decididor, que não deve tomar-se de preconceitos ao decidir.

casuística sem fim, convocasse o aplicador para participar da configuração do sentido adequado". FERRAZ JUNIOR, Tercio Sampaio. A Ciência do Direito. 2. ed. São Paulo: Atlas, 1980, p. 95.

${ }^{31}$ Aqui insere-se na zona de penumbra Hartiana, problema típico da linguagem natural na qual são elaboradas as normas jurídicas.

${ }^{32}$ FERRAZ JUNIOR, Tercio Sampaio. Introdução ao Estudo do Direito: técnica, decisão, dominação. 6. ed. rev. e ampl. São Paulo: Atlas, 2008, p. 294.

${ }^{33}$ Embora o legislador possa proceder à limitação ou definição que torne o conceito determinado. Assim, se a expressão período noturno possa ser vaga, a definição/explicitação tal como na legislação celetista, CLT, Art. 73, $\S 2^{\circ}$, in verbis - $\S 2^{\circ}$ Considera-se noturno, para os efeitos deste artigo, o trabalho executado entre as 22 horas de um dia e as 5 horas do dia seguinte; que regulamenta o trabalho noturno, torna preciso e determinado o conceito. 34 BRASIL. Supremo Tribunal Federal. Súmula Vinculante $\mathrm{n}^{\mathbf{0}}$ 11. Disponível em: < http://www.stf.jus.br/arquivo/cms/jurisprudenciaSumulaVinculante/anexo/Enunciados_Sumula_Vinculante_STF 11_a_29_31_e_32.pdf>. Acesso em: 15 jul. 2012.

35 ENGISH, Karl. Introdução ao Pensamento Jurídico. Tradução de J. Baptista Machado. 6. ed. Lisboa: Fundação Calouste Gulbenkian, 1983, p. 210.

${ }^{36}$ FERRAZ JUNIOR, Tercio Sampaio. A Ciência do Direito. 2. ed. São Paulo: Atlas, 1980, p. 95-96.

${ }^{37}$ FERRAZ JUNIOR, Tercio Sampaio. A Ciência do Direito. 2. ed. São Paulo: Atlas, 1980, p. 96. 
No entanto, como aponta o mesmo autor, a concreção dos conteúdos normativos está balizada no próprio sistema, segundo princípios, como o da legalidade, ao vincular o julgador à lei e vedar-lhe decisões contra legem ${ }^{38}$.

Mas também a própria lei confere, por meio do poder discricionário, especialmente em sede de Direito Administrativo, a possibilidade de avaliação da oportunidade e conveniência. Em âmbito jurisdicional, tal poder dá ao julgador, por exemplo, no processo penal, a possibilidade de sopesar entre diversas alternativas de mensuração da aplicação concreta da pena.

Ou seja, existem alternativas possíveis e um espaço de livre apreciação entre elas, daí porque Engish afirma que “Mais difícil do que demonstrar que existe o 'poder discricionário' no direito é demonstrar que isso é, não apenas inevitável, mas também algo de bom”39, no sentido de permitir ajustar as decisões às peculiaridades do caso, o que não significa arbitrariedade, visto que a discricionariedade seria ajuste de meios, mas mantendo-se a vinculação às possibilidades outorgadas pelo ordenamento, ou ao telos geral do sistema ${ }^{40}$.

No caso das lacunas, embora o dogma positivista postulasse a unidade, coerência e completude do ordenamento jurídico e, e em uma versão forte ou exegética, negasse-as sob o argumento de que não haveria lacuna por existir juiz para colmatá-la, o simples fato da colmatação já é indicativo de sua existência.

Segundo Alchourrón e Bulygin, o ideal de completude trata-se de um ideal racional ${ }^{41}$ que constitui pressuposto de toda atividade científica. E a exigência de completude dos sistemas normativos seria uma regra ideal, intrinsecamente ligada à função destes de tornar possível a adjudicação. Mas, como alertam os autores, é um equívoco confundir o ideal com a realidade $^{42}$. Portanto, há de se distinguir a exigência de que todo sistema jurídico seja completo, da afirmação de que toda ordem jurídica é efetivamente completa ${ }^{43}$.

\footnotetext{
${ }^{38}$ FERRAZ JUNIOR, Tercio Sampaio. Introdução ao Estudo do Direito: técnica, decisão, dominação. 6. ed. rev. e ampl. São Paulo: Atlas, 2008, p. 294.

39 ENGISH, Karl. Introdução ao Pensamento Jurídico. Tradução de J. Baptista Machado. 6. ed. Lisboa: Fundação Calouste Gulbenkian, 1983, p. 224.

${ }^{40}$ FERRAZ JUNIOR, Tercio Sampaio. Introdução ao Estudo do Direito: técnica, decisão, dominação. 6. ed. rev. e ampl. São Paulo: Atlas, 2008, p. 294.

${ }^{41}$ Os autores explicam quanto ao binômio ideal racional que se refere à atividade racional por excelência de explicar, fundamentar e dar razões. ALCHOURRÓN, C.; BULYGIN, E. Introducción a la metodología de las ciencias jurídicas e sociales. Buenos Aires: Astrea, 1971, p. 229.

42 "Pero el ideal que hemos querido hacer explícito no debe confundirse con la realidad. De la exigencia de que los sistemas normativos sean completos no se puede inferir que efectivamente lo son. Tal inferencia se funda en una conocida falacia. Sin embargo, la creencia de que todos los sistemas jurídicos son completos, no sólo es compartida por numerosos teóricos del derecho, sino que incluso se halla plasmada en muchas legislaciones positivas. En efecto, cabe mostrar que las exigencias que, tales legislaciones ponen a los jueces parecen presuponer que la completitud del orden jurídico, no sólo es un ideal, sino un hecho. Este postulado de la plenitud hermética del derecho cumple - a diferencia del ideal de completitud que tiene fundamento
} 
Daí porque o postulado de completude na atividade de interpretação, faticamente, não exclui a existência de lacunas e, portanto, não só não está afastada a interpretação, como se desejou no pretérito, ao se propor como em Montesquieu um juiz como mera "boca da lei"44, como ela é imprescindível no processo adjudicativo ${ }^{45-46}$. Tanto assim que, conforme Karl Engish, nota-se lacuna da lei quando dela não se consegue retirar, por meio de interpretação, qualquer resposta para uma questão jurídica ${ }^{47-48}$. As lacunas podem, inclusive, ser decorrência de mudanças sociais, tal como ocorre em relação às inovações tecnológicas, na biossegurança, na reprodução assistida e outras.

Além da distinção entre lacunas normativas e axiológicas já explicitada, Alchourrón e Bulygin diferenciam também entre lacunas de conhecimento e de reconhecimento. Há lacuna de conhecimento quando não se sabe se os casos individuais pertencem ou não a certa classe de casos genéricos, por falta de conhecimento das propriedades de fato do caso (individual).

exclusivamente racional - una función política: es una ficción tendiente a disimular la inconsistencia de ciertos ideales políticos fuertemente arraigados en el pensamiento jurídico (Secs. 6 y 7). ALCHOURRÓN, C.; BULYGIN, E. Introducción a la metodología de las ciencias jurídicas e sociales. Buenos Aires: Astrea, 1971, p. 227.

${ }^{43}$ Ainda os autores: “... 'postulado de la plenitud hermética del derecho' supone una confusión entre el ideal y la realidad. Creer que los sistemas jurídicos son completos porque deben serlo es una ilusión; derivar la completitud de la exigencia de completitud es una falácia". ALCHOURRÓN, C.; BULYGIN, E. Introducción a la metodología de las ciencias jurídicas e sociales. Buenos Aires: Astrea, 1971, p. 236-237.

${ }^{44}$ Como aponta Tercio Sampaio Ferraz Junior, ainda muito antes já havia tal postulação: "É hoje um postulado quase universal da ciência jurídica a tese de que não há norma sem interpretação, ou seja, toda norma é, pelo simples fato de ser posta, passível de interpretação. Houve, é verdade, na antigüidade [sic], exemplos de rompimento radical desta tese, como a conhecida proibição de Justiniano de que se interpretassem as normas do seu Corpus Juris". FERRAZ JUNIOR, Tercio Sampaio. A Ciência do Direito. 2. ed. São Paulo: Atlas, 1980, p. 67.

${ }^{45}$ Como expõe Engish: “... a tarefa da interpretação é fornecer ao jurista o conteúdo e o alcance (extensão) dos conceitos jurídicos. A indicação do conteúdo é feita por meio duma definição, ou seja, pela indicação das conotações conceituais (espaço fechado é um espaço que...). A indicação do alcance (extensão) é feita pela apresentação de grupos de casos individuais que são de subordinar, quer dizer, subsumir, ao conceito jurídico". ENGISH, Karl. Introdução ao Pensamento Jurídico. Tradução de J. Baptista Machado. 6. ed. Lisboa: Fundação Calouste Gulbenkian, 1983, p. 126.

${ }^{46}$ A esse respeito, Juliano Maranhão discorre em sua tese, refutando o brocardo clara non sunt interpretanda e ratificando o in claris cessat interpretatio. Ou seja, é a interpretação que dá ao texto a clareza ou lhe desvela o sentido. Não se fala em clareza sem interpretação, então esta vai até onde seja necessário para esclarecer o sentido. Vide: MARANHÃO, Juliano Souza de Albuquerque. Inclusivismo Lógico: uma contribuição à metodologia jurídica. Tese de livre-docência, Departamento de Filosofia e Teoria Geral do Direito, Universidade de São Paulo, São Paulo, 2010.

47 "Na medida em que a interpretação baste para responder às questões jurídicas, o Direito não será, pois, lacunoso". ENGISH, Karl. Introdução ao Pensamento Jurídico. Tradução de J. Baptista Machado. 6. ed. Lisboa: Fundação Calouste Gulbenkian, 1983, p. 280.

${ }^{48}$ Engish, ampliando a base normativa, distingue entre lacuna da lei e do Direito: "Se, pelo contrário, ao falarmos de "Direito", pensarmos no "Direito positivo" na sua totalidade, o qual, além do Direito legislado, também abrange o Direito consuetudinário, então só teremos uma lacuna jurídica quando nem a lei nem o Direito consuetudinário nos deem [sic] resposta a uma questão jurídica. Se o Direito consuetudinário nos fornece qualquer indicação onde a lei nos não diz nada, encontramo-nos perante uma lacuna da lei, mas não em face de uma lacuna do Direito positivo". O autor ainda distingue as verdadeiras lacunas das por ele chamadas "lacunas político-jurídicas', como já exposto na nota 22. ENGISH, Karl. Introdução ao Pensamento Jurídico. Tradução de J. Baptista Machado. 6. ed. Lisboa: Fundação Calouste Gulbenkian, 1983, p. 277. 
Já na lacuna de reconhecimento, não se sabe se os casos individuais pertencem ao caso genérico em questão, em razão da falta de determinação semântica dos conceitos que caracterizam um caso genérico, o que seria uma decorrência do problema de penumbra referido por Hart ${ }^{49}$.

Portanto, mesmo que não haja lacuna normativa e, pois, o sistema jurídico proveja solução ao problema, a adjudicação via dedutiva encontra ainda como empecilhos a falta de informações sobre os fatos do caso (lacuna de conhecimento); e a indeterminação semântica ou vagueza dos conceitos gerais (lacuna de reconhecimento), dificultando a subsunção.

Quanto aos princípios jurídicos, parte-se da premissa de que os operadores do Direito e a dogmática identifiquem exemplos prototípicos, sem o compromisso de sua definição ou caracterização $^{50}$. O fato é que se vive hodiernamente o primado dos direitos humanos em âmbito internacional com sua correspondência no âmbito interno dos direitos fundamentais, inserindo princípios nas Cartas constitucionais das democracias contemporâneas, o que abre espaço para deliberações e discussões valorativas referentes a direitos fundamentais e programas de políticas públicas, seja pelos juízes, seja pela dogmática.

Surgem assim, as situações de conflito, ou na postulação de Robert Alexy, colisão de princípios, de modo que o julgador vê-se em uma situação em que deve previamente escolher a premissa maior, entre mais de uma possível, a fim de proceder dedutivamente à solução. Este, como os demais casos, denota as dificuldades e limitações à aplicação subsuntiva do Direito.

Daí porque Karl Larenz aponta o último quarto do século XX como marcado pela perda de certeza no pensamento jurídico, aceitando-se soluções plausíveis ou suscetíveis de consenso e não estritamente certas; transcendo-se o texto legal, mas sem prescindir da lei, visto que "As leis continuam a desempenhar na nossa vida jurídica, tal como dantes, um enorme papel: os juízes estão obrigados a elas recorrer... De outro modo deixariam as leis de

\footnotetext{
${ }^{49}$ Hart, ao distinguir entre a zona de certeza, onde há um núcleo de amplitude semântica determinada e a zona de penumbra, caracterizada por vagueza ou ambiguidade, atribui o problema ao fato de as normas serem emanadas em linguagem natural, já em si portadora de tais problemas. Vide: HART, Herbert L. A. El concepto de Derecho. Traducción de Genaro R. Carrió. Buenos Aires: Abeledo-Perrot, 1963.

${ }^{50}$ Para tanto, vejam-se os apontamentos de Juliano Maranhão relativos a diversas acepções doutrinárias sobre o conceito de princípio. MARANHÃO, Juliano Souza de Albuquerque. Inclusivismo Lógico: uma contribuição à metodologia jurídica. Tese de livre-docência, Departamento de Filosofia e Teoria Geral do Direito, Universidade de São Paulo, São Paulo, 2010, p. 75 et seq.
} 
ser 'cogentes' e falhariam a [sic] sua tarefa de direcção [sic] no seio da comunidade" "51. Isso denota a seguinte mudança, conforme a sintética constatação de Karl Engish ${ }^{52}$ :

\begin{abstract}
Houve um tempo em que tranquilamente se assentou na ideia de que deveria ser possível estabelecer uma clareza e segurança jurídicas absolutas através de normas rigorosamente elaboradas, e especialmente garantir uma absoluta univocidade a todas as decisões judiciais e a todos os actos [sic] administrativos. Esse tempo foi o do iluminismo [...] A desconfiança que haviam chamado sobre si os juízes no período da justiça de arbítrio e de gabinete (quer dizer, de uma justiça que se acomodava às instruções dos senhores da terra) e, por outro lado, a adoração da lei animada por um espírito nacionalista, fizeram com que a estrita vinculação do juiz à lei se tornasse no postulado central. Ao mesmo tempo, foi-se conduzido ao exagero de estabelecer insustentáveis proibições de interpretar e comentar a lei, à exclusão de qualquer graduação da pena pelo juiz (sistema das 'peines fixes' no Code pénal de 1791) e outras coisas semelhantes. O juiz deveria ser o 'escravo da lei' (BOCKELMANN). Esta concepção da relação entre a lei e o juiz entrou de vacilar no decurso do século XIX. Começa então a considerar-se impraticável o postulado da estrita vinculação do juiz à lei, por isso que não é possível elaborar as leis com tanto rigor e fazer a sua interpretação em comentários oficiais de modo tão exacto [sic] e esgotante que toda a dúvida quanto à sua aplicação seja afastada. A mais disso, com o tempo, deixa-se também de considerar como ideal aquela exigência da vinculação à lei. A situação actual [sic] é a seguinte: a vinculação à lei dos tribunais e das autoridades administrativas não está tão reduzida quanto, no começo do nosso século, a chamada Escola do Direito Livre considerou ser inevitável e correcto [sic]; está-o todavia em certa medida e de modo a obrigar-nos a comentar as nossas considerações metodológicas noutras direcções [sic] e por outras vias.
\end{abstract}

As dificuldades anteriormente apontadas denotam conforme o mesmo autor que "...a 'trivial' dedução a partir da premissa maior e da premissa menor não diz absolutamente nada sobre a dificuldade e a subtileza [sic] da elaboração daquelas mesmas premissas..."53.

Esses casos considerados difíceis pela ausência de inconteste predeterminação, não eximem, contudo, o julgador de buscar a solução jurídica e não simplesmente arbitrária. A dificuldade, no entanto, é que, se por um lado há a obrigatoriedade de julgar (non liquet) e de aplicar o direito posto (princípio da legalidade) em observância ao princípio da separação de poderes, como corolário do Estado de Direito; por outro, há a situação de não se poder extrair do ordenamento jurídico de forma cabal a solução para todos os problemas trazidos a juízo ou de as soluções levarem o julgador a uma situação de impossibilidade de agir, consoante

\footnotetext{
${ }^{51}$ LARENZ, Karl. Metodologia da Ciência do Direito. 3. ed. Tradução de José Lamego. Lisboa: Fundação Calouste, 1997, p. 2.

${ }^{52}$ ENGISH, Karl. Introdução ao Pensamento Jurídico. Tradução de J. Baptista Machado. 6. ed. Lisboa: Fundação Calouste Gulbenkian, 1983, p. 206.

${ }^{53}$ ENGISH, Karl. Introdução ao Pensamento Jurídico. Tradução de J. Baptista Machado. 6. ed. Lisboa: Fundação Calouste Gulbenkian, 1983, p. 383.
} 
constatação de Alchourrón e Bulygin ${ }^{54}$ de que : "las exigencias expresadas en los principios de inexcusabilidad, justificación y legalidad son conjuntamente insostenibles, ya que imponen a los jueces obligaciones imposibles de cumplir", visto que nem sempre a lei lhes dá as justificações que lhes permitam julgar conforme a lei.

Ou doutra sorte, a imponderabilidade entre a solução de alguns casos de conflito de princípios - o que se enfocará no estudo, atentando-se especialmente a este caso de limitação da subsunção, tendo-se em vista a tendência potencial de aumento de tais casos, já empiricamente notado nos últimos anos, dado o caráter social e dirigente da Constituição em vigor - e a exigência de vinculação à lei.

Na ponderação, para se solucionar esses casos, como se verá, ocorre a situação notada por Engish em relação a todos os casos supracitados de limitação da subsunção, em que se dá abertura à equidade e, "subsiste um resíduo de apreciação pessoal que não é susceptível [sic] de análise racional, que não deve apenas ser suportado por não haver 'outro remédio' mas ser até bem recebido..."

A questão, então, que fica como mote da reflexão é: nesses casos de ponderação, de fato, não há possibilidade de conciliação com as normas postas? A discussão que se segue é de apresentação da clássica proposta de solução de conflito de princípios por Robert Alexy, para na sequência apresentar-se o modelo coerentista como proposta de justificação das decisões tomadas à luz do direito posto, com vistas a se buscar a racionalidade decisória. Finalizando-se no sentido de verificar de forma estrita - não se permitindo falar genericamente da atuação da Corte Suprema pátria, como já apontado - a solução de conflito de princípios pelo Supremo Tribunal Federal em dois casos decididos pela Corte.

\subsection{O MÉTODO DA PONDERAÇÃO}

\subsubsection{Apresentação da teoria de Robert Alexy}

O método da ponderação para solução de conflito de princípios proposto por Robert Alexy parte de sua distinção teórico-estrutural entre regras e princípios considerada como

\footnotetext{
${ }^{54}$ ALCHOURRÓN, C.; BULYGIN, E. Introducción a la metodología de las ciencias jurídicas e sociales. Buenos Aires: Astrea, 1971, p. 238-239.

${ }_{55}$ ENGISH, Karl. Introdução ao Pensamento Jurídico. Tradução de J. Baptista Machado. 6. ed. Lisboa: Fundação Calouste Gulbenkian, 1983, p. 247.
} 
necessária para se ter uma teoria adequada sobre as restrições a direitos fundamentais, sobre suas colisões e sobre o papel dos direitos fundamentais no sistema jurídico. Além disso, essa distinção constitui, segundo Alexy, "a estrutura de uma teoria normativo-material dos direitos fundamentais e, com isso, um ponto de partida para a resposta à pergunta acerca da

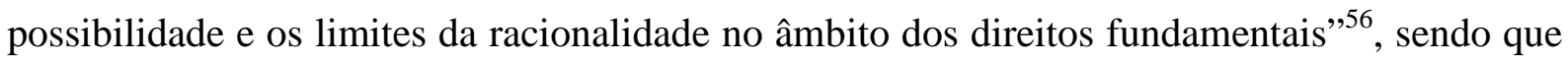
esses direitos encontram-se no viés alexyano na categoria de princípios.

Embora a classificação do gênero "norma jurídica" tendo por espécies as regras e os princípios não seja criação de Alexy ${ }^{57-58}$, essa é a base para sua teoria dos direitos fundamentais; e, pautado nessa diferenciação, ele lança a proposta da metodologia da ponderação para solução de casos em que haja conflitos - ou, na nomenclatura por ele usada, colisão de princípios, enquanto reserva o termo 'conflito' para regras contrapostas.

Para formular a diferenciação, Alexy parte da negação de características que considerada como não distintivas. Assim, primeiramente nega que a diferença entre regas e princípios seja meramente de grau de generalidade, ou seja, que princípios sejam normas de grau de generalidade relativamente alto, enquanto as regras, normas de grau de generalidade relativamente baixo.

O critério distintivo que Alexy considera correto é de ordem qualitativa, já que existe um caráter distinto prima facie entre regras e princípios: as regras contêm determinações no âmbito do que é fática e juridicamente possível e, uma vez válidas, deve-se fazer exatamente aquilo que determinam ${ }^{59}$; já os princípios não contêm um mandamento definitivo, mas apenas prima facie, o que significa que exigem que algo seja realizado na maior medida possível dentro das possibilidades jurídicas e fáticas existentes ${ }^{60}$. E, com base em tal distinção outro

\footnotetext{
${ }^{56}$ ALEXY, Robert. Teoria dos Direitos Fundamentais. Tradução de Virgílio Afonso da Silva. São Paulo: Malheiros, 2008, p. 85.

57 Como registra o próprio Alexy, a distinção entre regras e princípios já havia sido delineada nos 1940 na Áustria por Walter Wilburg e por Josef Esser nos anos 1950 na Alemanha. Conf.: ALEXY, Robert. On the structure of legal principles. Ratio Juris, v. 13, n. 3, p. 294-304, set. 2000.

${ }^{58}$ Segundo Humberto Ávila, Josef Esser definiu princípio como fundamento, critério para justificação de uma ordem. Outras distinções entre regras e princípio também foram feitas, embora com base em critérios distintos, como a de Karl Larenz, que define princípios como normas de grande relevância, por fornecerem fundamentos para a interpretação e a aplicação do direito; ou a de Canaris na caracterização da norma como princípio com base na explicitude de seu conteúdo axiológico. Vide: ÁVILA, Humberto. Teoria dos Princípios - da definição à aplicação dos princípios jurídicos. 4. ed. rev. 3. tir. São Paulo: Malheiros, 2005.

${ }^{59}$ Isso não significa que Alexy desconsidere a questão da interpretação, até mesmo porque a subsunção dos fatos à norma não prescinde de interpretação: "Como as regras exigem que seja feito exatamente aquilo que elas ordenam, elas têm uma determinação da extensão de seu conteúdo no âmbito das possibilidades jurídicas e fáticas. Essa determinação pode falhar diante de impossibilidades jurídicas e fáticas; mas se isso não ocorrer, então, vale definitivamente aquilo que a regra prescreve”. ALEXY, Robert. Teoria dos Direitos Fundamentais. Tradução de Virgílio Afonso da Silva. São Paulo: Malheiros, 2008, p. 104.

${ }^{60}$ Segundo esse critério de Alexy, seria errôneo falar-se, por exemplo, de princípio da legalidade, da nulla poena sine lege, da anterioridade, pois nesses casos não há efetivamente mandamentos de otimização, mas determinações que devem ser cumpridas. Conf.: SILVA, Virgílio Afonso da. Princípios e regras: mitos e
} 
critério distintivo passa a ser a forma de solução de conflito de regras e colisão de princípios, isso porque o conflito de regras diz respeito à validade da regra, já na colisão de princípios a questão é relativa ao peso.

Desse modo, havendo conflito entre regras, caracterizado pela determinação de soluções distintas e inconciliáveis para o mesmo caso, daí porque excludentes, seriam possíveis duas soluções: ou se introduziria em uma das regras uma cláusula de exceção que eliminasse o conflito ${ }^{61}$ ou uma das regras deveria ser declarada inválida, o que seria um problema, pois não há uma predeterminação de qual delas deva ser mantida ou não ${ }^{62}$.

Já o caso de colisão de princípios, como referido, não se trata de problema de validade, mas de peso, e a solução é contextual: um princípio não afasta o outro do ordenamento, mas apenas afasta a aplicação do princípio colidente no caso concreto, o que não necessariamente valerá para outros casos, já que o princípio com maior peso em um caso, o que justifica sua aplicação, pode não ser o de maior peso em outro, sendo afastado pelo de peso preponderante.

Daí Alexy falar de uma relação de precedência condicionada entre os princípios, já que tem por base as circunstâncias do caso concreto. E para se saber qual o princípio de maior peso concreto e, portanto, o princípio preponderante no caso, há a necessidade de se resolver a colisão por meio de sopesamento entre os interesses conflitantes, abstratamente em mesmo nível $^{63}$.

Alexy concebe a possibilidade de a precedência ter duplo caráter: ser condicionada (relativamente a certas circunstâncias) ou incondicionada (precedência abstrata ou absoluta), independente de circunstâncias. No entanto, considerando-se que nenhum direito, ainda que fundamental, é absoluto - mesmo nos casos em que parece inderrotável perante outros, como é o caso do direito à vida ou a dignidade da pessoa humana, isso não significa que não haverá nenhuma hipótese em que o princípio não poderá ser afastado -, o autor conclui que resta a precedência condicionada ou relativa.

equívocos acerca de uma distinção. Revista Latino-Americana de Estudos Constitucionais, v. 1, p. 607-630, 2003.

${ }^{61}$ Essa é uma das diferenciações entre Alexy e Dworkin. Embora ambos distingam as normas entre regras e princípios, Dworkin não cogita da possibilidade da inserção de exceção para manter a validade das regras conflitantes, determinando como única solução a exclusão de uma das regras do ordenamento por ser considerada inválida: para a regra, a solução é 'tudo-ou-nada', a despeito do caráter prima facie - o que justifica sua derrotabilidade possível em casos concretos - dos princípios. Alexy considera simplista a formulação de tudo ou nada de Dworkin, uma vez que a admissibilidade de uma cláusula de exceção poderia ser solução para o problema com manutenção da validade de ambas as regras conflitantes. DWORKIN, Ronald. Taking Rights Seriously. Cambridge, MA: Harvard University Press, 1978.

${ }^{62}$ ALEXY, Robert. Teoria dos Direitos Fundamentais. Tradução de Virgílio Afonso da Silva. São Paulo: Malheiros, 2008, passim.

${ }_{63}$ ALEXY, Robert. Teoria dos Direitos Fundamentais. Tradução de Virgílio Afonso da Silva. São Paulo: Malheiros, 2008, p. 95-96. 
Assim, "Em um caso concreto, o princípio $P_{1}$ tem prevalência sobre o $P_{2}$ se houver razões suficientes para que $P_{1}$ prevaleça sobre o $P_{2}$ sob as condições $C$, presentes nesse caso concreto" e, com isso, "a questão decisiva é, portanto, sob quais condições qual princípio deve prevalecer e qual deve ceder. Nesse contexto, o Tribunal Constitucional Federal [alemão] utiliza-se muito da metáfora do peso"64. Disso se extraem duas postulações de Alexy: (i) a relevância das circunstâncias concretas, que comporão o suporte fático da regra extraída do princípio prevalecente; e (ii) que o peso de um princípio é relativo a outro princípio com o qual entra em colisão e não absoluto ou universal, o que enseja a variabilidade de decisões sobre o mesmo princípio $P$ a depender das circunstâncias concretas e dos princípios que venham a colidir com $P$.

A condição de precedência é suporte fático da norma, já que diante da presença da condição de precedência, a regra prescreve a consequência jurídica do princípio prevalente. Alexy ilustra dizendo que "(K) Se o princípio $P_{1}$ tem precedência em face do princípio $P_{2}$ sob as condições C: $\left(P_{1} \mathbf{P} P_{2}\right) C$, e se do princípio $P_{1}$, sob as condições $C$, decorre a consequiência [sic] jurídica $R$, então, vale uma regra que tem $C$ como suporte fático e $R$ como conseqüência [sic] jurídica: $C \rightarrow R$ ”, ou em uma linguagem menos técnica: “( $\mathrm{K}$ ') As condições sob as quais um princípio tem precedência em face de outro constituem o suporte fático de uma regra que expressa a conseqüência [sic] jurídica do princípio que tem precedência"65. Ou seja, a condição de precedência determina a consequência jurídica da aplicação do princípio prevalecente. Daí, porque, permite-se a formulação de uma regra. Como explica Alexy ${ }^{66}$ :

[...] O caminho que vai do princípio, isto é, do direito prima facie, até o direito definitivo passa pela definição de uma relação de preferência. Mas a definição de uma relação de preferência é, segundo a lei de colisão, a definição de uma regra. Nesse sentido, é possível afirmar que sempre que um princípio for, em última análise, uma razão decisiva para um juízo concreto de dever-ser, então, esse princípio é o fundamento de uma regra, que representa uma razão definitiva para esse juízo concreto.

Dessa forma, Alexy esclarece que as disposições de direitos fundamentais, as quais contêm as normas de direito fundamental, são compreendidas como princípios, e as regras surgem da fixação das relações de precedência como resultados de sopesamentos, mediante considerações das condições sob as quais um princípio prevalece sobre o outro. Essas

\footnotetext{
${ }^{64}$ ALEXY, Robert. Teoria dos Direitos Fundamentais. Tradução de Virgílio Afonso da Silva. São Paulo: Malheiros p. 97.

${ }^{65}$ ALEXY, Robert. Teoria dos Direitos Fundamentais. Tradução de Virgílio Afonso da Silva. São Paulo: Malheiros, 2008, p. 99.

${ }^{66}$ ALEXY, Robert. Teoria dos Direitos Fundamentais. Tradução de Virgílio Afonso da Silva. São Paulo: Malheiros, 2008, p. 108.
} 
condições serão o suporte fático da regra e a consequência jurídica será a determinada pelo princípio prevalecente. E para se saber qual é o princípio prevalecente, procede-se à ponderação ${ }^{67}$ dos princípios colidentes.

Nesse passo, Alexy explica que a natureza dos princípios como mandamentos de otimização implica a máxima da proporcionalidade, com suas três máximas parciais: i) adequação, ii) necessidade (mandamento do meio menos gravoso) e iii) proporcionalidade em sentido estrito (mandamento do sopesamento propriamente dito). Segundo a máxima da proporcionalidade, que corresponderia à lei de ponderação de Alexy, quanto maior o grau da insatisfação ou afetação de um princípio, tanto maior deve ser a importância de satisfazer ao outro $^{68}$.

Assim, para se determinar o princípio prevalecente em um caso mediante ponderação, deve-se aplicar a máxima da proporcionalidade, com suas máximas parciais. Quanto às duas primeiras, adequação e necessidade, dizem respeito à otimização em face das possibilidades fáticas. A adequação implica que não se devem adotar meios que obstem a realização de um princípio sem promover o outro princípio, daí porque Alexy entende que o princípio da adequação não é senão uma expressão da ideia da eficiência de Pareto: uma posição pode ser melhorada sem que outra seja piorada ${ }^{69}$.

Por exemplo, se se pretende fomentar a saúde (princípio $S$ ), mas não prejudicar a liberdade de comércio de uma empresa de alcoólicos (princípio C), uma medida como a colocação em rótulos de bebidas alcoólicas de alertas sobre os males do produto no organismo, teria potencial de fomentar o princípio $\mathrm{S}$, sem que a afetação potencial à liberdade de comércio fosse considerada desproporcional; o que implicaria que a medida seria considerada razoável $^{70}$ e, logo, sua utilização seria adequada ${ }^{71}$.

\footnotetext{
${ }^{67}$ Segundo Carlos Bernal Pulido, "La palabra ponderación deriva de la locución latina pondus que significa peso. Esta referencia etimológica es significativa, porque cuando el juez o el fiscal pondera, su función consiste en pesar o sopesar los principios que concurren al caso concreto. La ponderación es entonces la actividad consistente en sopesar dos principios que entran en colisión en un caso concreto para determinar cuál de ellos tiene un peso mayor en las circunstancias específicas, y, portanto, cuál de ellos determina la solución para el caso. En razón de esta función, la ponderación se ha convertido en un criterio metodológico indispensable para el ejercicio de la función jurisdiccional, especialmente la que se desarrolla en las Cortes Constitucionales, que se encargan de la aplicación de normas que, como los derechos fundamentales, tienen la estructura de principios.". PULIDO, Carlos Bernal. La ponderación como procedimiento para interpretar los derechos fundamentales. In: . Problemas contemporáneos de la filosofía del derecho. Colombia: Universidad Autonoma De Mexico, 2005, p. 17-35, p. 19-10.

${ }^{68}$ ALEXY, Robert. ALEXY, Robert. Teoria dos Direitos Fundamentais. Tradução de Virgílio Afonso da Silva. São Paulo: Malheiros, 2008, p. 116 et. seq.

${ }^{69}$ ALEXY, Robert. Constitutional Rights, Balancing and Rationality. Ratio Juris, v. 16, n. 2, p. 131-140, jun. 2003, p. 135.

70 Virgílio Afonso da Silva esclarece que a máxima da proporcionalidade é distinta da razoabilidade. A razoabilidade diz respeito à compatibilidade entre o meio empregado pelo legislador e os fins visados, bem como a legitimidade dos fins. A razoabilidade, pois, estaria inserida na máxima da proporcionalidade em sentido
} 
Quanto à necessidade, também é expressão da eficiência de Pareto e se trata da possibilidade fática de otimização da aplicação de princípios. Segundo a máxima da necessidade, entre dois meios de se promover um princípio $\mathrm{P}_{1}$, sendo ambos os meios considerados adequados - tomando o exemplo anterior, suponha-se outra medida como a proibição de venda de alcoólicos depois das duas horas da manhã, que poderia ser considerada adequada se potencialmente fomentasse a saúde e não interferisse sobremaneira na liberdade de comércio; logo, ambas as medidas seriam consideradas igualmente adequadas -, o meio que interferisse menos no princípio $\mathrm{P}_{2}$, em colisão com $\mathrm{P}_{1}$, deveria ser adotado.

No exemplo, considerando-se que a medida de vedação de bebidas alcoólicas interferiria mais intensamente no princípio $\mathrm{C}$ do que a medida da aposição de mensagem de alerta, a medida a ser escolhida seria a do alerta no rótulo por sua menor interferência em $\mathrm{C}$. A síntese, pois, da necessidade é que o objetivo ou princípio não poder ser realizado de outro modo menos gravoso.

Assim, passando pelo exame de necessidade, sendo considerada uma medida necessária pela constatação de que é mesmo preciso sacrificar, ao menos parcialmente, um dos princípios para salvaguardar o outro, deve-se proceder à verificação da possibilidade jurídica, por meio da terceira máxima, da proporcionalidade em sentido estrito, já que, nesse caso, havendo mais de uma alternativa sem que faticamente tenha sido possível a exclusão de qualquer delas, será preciso uma escolha que não é questão de possibilidade fática, mas de possibilidade jurídica, ou seja, uma questão de sopesamento entre $P_{1}$ e $P_{2}$ (proporcionalidade em sentido estrito $)^{72-73}$.

No Posfácio à teoria dos direitos fundamentais, Alexy esclarece que a máxima da proporcionalidade em sentido estrito é idêntica à lei do sopesamento cuja determinação é:

amplo, pois corresponderia à exigência de adequação. SILVA, Virgílio Afonso da. O proporcional e o razoável. Revista dos Tribunais, a. 91, v. 798, p. 23-50, abr. 2002, p. 32-33.

${ }^{71}$ Alexy acrescenta que a máxima da adequação não aponta para um ponto máximo em termos de otimização: "Essa máxima tem, na verdade, a natureza de um critério negativo. Ela elimina meios inadequados. Um tal critério negativo não determina tudo, mas exclui algumas coisas. Nesse sentido, ele ajusta-se à idéia [sic] de uma ordem-moldura. Como elemento de uma ordem como essa, ele exclui algumas coisas - a saber: aquilo que não é adequado - sem, com isso, determinar tudo". ALEXY, Robert. Posfácio (2002). In: Teoria dos Direitos Fundamentais. Tradução de Virgílio Afonso da Silva. São Paulo: Malheiros, 2008, p. 575-627, p. 590.

${ }^{72}$ ALEXY, Robert. Teoria dos Direitos Fundamentais. Tradução de Virgílio Afonso da Silva. São Paulo: Malheiros, 2008, p. 119-120.

${ }^{73}$ Como salienta Virgílio Afonso da Silva, a aplicação da máxima da proporcionalidade nem sempre implica a análise de todas as suas três sub-regras, já que estas se relacionam de forma subsidiária. "Com subsidiariedade quer-se dizer que a análise da necessidade só é exigível se, e somente se, o caso já não tiver sido resolvido com a análise da adequação; e a análise da proporcionalidade em sentido estrito só é imprescindível, se o problema já não tiver sido solucionado com as análises da adequação e da necessidade. Assim, a aplicação da regra da proporcionalidade pode esgotar-se, em alguns casos, com o simples exame da adequação do ato estatal para a promoção dos objetivos pretendidos". SILVA, Virgílio Afonso da. O proporcional e o razoável. Revista dos Tribunais, a. 91, v. 798, p. 23-50, abr. 2002, p. 34. 
quanto maior for o grau de não satisfação ou de afetação de um princípio, tanto maior terá de ser a importância da satisfação do outro. De modo que o autor conclui que a otimização em relação aos princípios colidentes é o seu sopesamento. Este, por sua vez, pode ser dividido em três passos: no primeiro passo se avalia o grau de não satisfação ou de afetação de um dos princípios colidentes; no segundo passo, avalia-se a importância da satisfação do outro princípio colidente; em um terceiro passo, avalia-se se a importância da satisfação do princípio colidente justifica a afetação ou a não satisfação do outro princípio ${ }^{74}$. Destarte, o método da ponderação ${ }^{75}$ para solução de colisão de princípios poderia ser sintetizado no seguinte quadro sinótico:

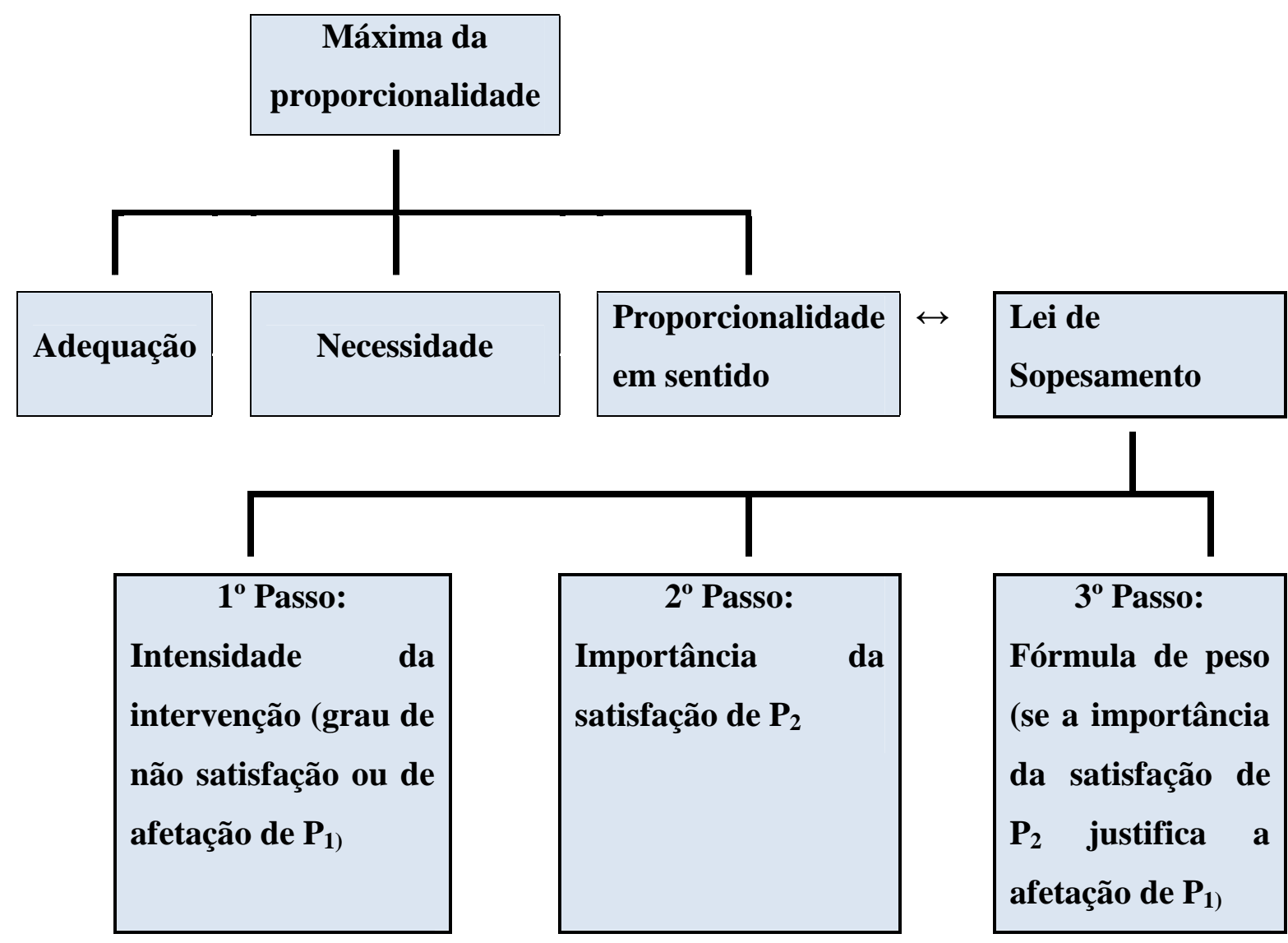

\footnotetext{
${ }^{74}$ ALEXY, Robert. Teoria dos Direitos Fundamentais. Tradução de Virgílio Afonso da Silva. São Paulo: Malheiros, 2008, p. 593-594.

75 Segundo Carlos Bernal Pulido a estrutura da ponderação está composta por três elementos: a lei da ponderação, a fórmula de peso e a carga ou ônus da argumentação. Quanto ao primeiro, determina exatamente o mesmo que a lei de sopesamento, sendo, pois, sinônima desta e, logo, da proporcionalidade em sentido estrito. A fórmula de peso determina que o peso concreto de um princípio em relação ao outro deriva do cociente entre o produto da a importância do primeiro, seu peso abstrato e a segurança das apreciações empíricas sobre sua importância e o produto da a importância do segundo, seu peso abstrato e a segurança das apreciações empíricas sobre sua importância. No caso de empate entre o peso dos princípios colidentes, poder-se-ia recorrer ao ônus da argumentação. PULIDO, Carlos Bernal. La racionalidad de la ponderación. IN: CARBONELL, Miguel (Coord.). El principio de proporcionalidad y la protección de los derechos fundamentales. México, DF: Comisión Nacional de los Derechos Humanos, 2008, p. 39-61, passim.
} 
Para a definição da intensidade da intervenção em um princípio Pi e a importância da satisfação do outro princípio colidente $\mathrm{Pj}$, pode-se usar uma escala com as categorias leve, moderado e sério ou grave, simbolizadas, respectivamente por $l, m, g^{76}$. A fórmula de peso resultará do quociente entre a intensidade da intervenção em $\mathrm{Pi}$, que definirá o peso concreto de Pi nas circunstâncias do caso, já que a intensidade das intervenção ou não-satisfação de um princípio Pi são sempre concretas; e a importância de satisfação de $\mathrm{Pj}$, considerando-se tanto as circunstâncias do caso, o que resulta em um peso concreto, como o peso abstrato dos princípios em colisão, que entram no cálculo, caso sejam diferentes ${ }^{77}$. Para a intensidade da intervenção pode-se usar a dotação simbólica IPi e, como se afere concretamente, pode-se acrescentar, sem implicar alterações, a letra $C$ para explicitar que a intensidade da afetação em Pi é sempre concreta $(\mathrm{IPiC}=\mathrm{IPi})$.

No atinente ao segundo passo, a determinação da importância de se satisfazer o outro princípio, duas grandezas podem ser relevantes: a grandeza abstrata, que diz respeito à importância de um princípio em abstrato - por exemplo, em geral, há a premissa de que o direito à vida tem peso abstrato maior que a liberdade - e a grandeza concreta, aferida mediante consideração das circunstâncias do caso. Quando dois princípios tenham pesos abstratos iguais (ambos fundamentais e de mesma importância, como vida e dignidade, por exemplo), o peso abstrato pode ser desconsiderado no cálculo, que dependerá apenas do peso concreto. Adota-se simbolicamente 'W' para a importância de se satisfazer o princípio $\mathrm{Pj}$ em colisão com $\mathrm{Pi}$, cuja afetação fora aferida no primeiro passo - e ' $\mathrm{C}$ ' para denotar que o peso é concreto, de modo que a importância concreta de $\mathrm{Pj}$ pode ser simbolizada por WPjC, caso se tratasse de peso abstrato, $\mathrm{C}$ poderia ser substituído pelo indicativo ' $\mathrm{A}$ ' $(\mathrm{WPj} \mathrm{A}=$ peso abstrato do princípio $\mathrm{Pj}$ ).

E para se estabelecer a importância concreta de satisfazer $\mathrm{Pj}$, é preciso questionar no sentido contrário o que significaria para o princípio $\mathrm{Pj}$, se fosse omitida a intervenção em Pi. No exemplo usado, a importância de $\mathrm{S}$ (princípio relativo à saúde) se aferiria pela implicação

\footnotetext{
${ }^{76}$ Alexy concebe a possibilidade de um refinamento nessas categorias mediante uma escala mais depurada por meio de um modelo triádico duplo com nove possibilidades partindo do $l l$ (intervenção ou importância levíssima) até o $g g$ (intervenção ou importância gravíssima ou seriíssima). No entanto, esses refinamentos seriam limitados e só seriam aplicáveis com muita dificuldade, até porque, mesmo o modelo triádico simples já implica problemas para se discernir se uma intervenção seria fácil, moderada ou séria, com maior razão no modelo triádico duplo. ALEXY, Robert. Teoria dos Direitos Fundamentais. Tradução de Virgílio Afonso da Silva. São Paulo: Malheiros, 2008, p. 609-601.

${ }_{77}$ Note-se que o peso concreto de um princípio não necessariamente corresponde a seu peso abstrato. Exemplificativamente, considera-se que a vida humana tem, em abstrato, peso maior que a liberdade, no entanto, concretamente, uma mãe cuja gravidez implique risco de morte para si pode, até mesmo por força de regra permissiva (Art. 128, inciso I do CP) optar - logo, exercer sua liberdade -, pelo aborto (ceifando a vida do filho). Muito embora nesse caso haja conflito entre duas vidas, a prevalência de uma delas em detrimento da outra demonstra que o peso concreto da vida do filho não corresponde a seu peso abstrato.
} 
da não intervenção em C (liberdade de comércio) ou, no caso da honra (Pj) e da liberdade de expressão (Pi) a importância de $\mathrm{Pj}$ (honra) seria medida pela definição do quão intensamente a não-intervenção em Pi (liberdade de expressão) afetaria Pj (honra).

Por exemplo, se não houvesse nenhum limite à liberdade de expressão, tudo poderia ser dito e, consequentemente, em muitos casos, a honra poderia ser gravemente afetada, de modo que a importância da honra (Pj) justifica a intervenção na liberdade de expressão (Pi), assim como o fomento à saúde justificaria a intervenção na liberdade de comércio.

Portanto, segundo a lei de sopesamento, haveria três grupos de casos. No primeiro grupo, a interferência em Pi é mais intensa do que em $\mathrm{Pj}$ e, pois, $\mathrm{Pi}$ tem precedência sobre $\mathrm{Pj}$ nas condições C [(Pi P Pj) C] quando: (1) IPiC: g/WPjC: l, (2) IPiC: g/WPjC: $m$; (3) IPiC: $m / \mathrm{WPjC}: l$. No segundo grupo, a interferência em Pj é maior, e ele tem preferência [[( $\mathrm{Pj} \mathbf{P} \mathrm{Pi})$ C]: (4) IPiC: l,/WPjC: g; (5) IPiC: m/WPjC: g; (6) IPiC: l/WPjC: m. Finalmente, há um grupo de casos em que não há como aferir qual o princípio deve prevalecer, pois os pesos são equivalentes e, por conseguinte, não há como se determinar o prevalecente: (7) IPiC: l/ WPjC: l; (8) IPiC: $m / \mathrm{WPjC}: m$; (9) IPiC: $g / \mathrm{W} P j C: g^{78}$. Nos últimos três casos, dado o impasse no sopesamento, ocorreria o que Alexy chama de discricionariedade estrutural para $\operatorname{sopesar}^{79}$.

A partir desse conjunto de possibilidades, pode-se estabelecer a seguinte fórmula de peso: $\mathrm{GPi}, \mathrm{jC}=\mathrm{IPiC} / \mathrm{WPjC}$ (Leia-se: o peso concreto de Pi em relação a Pj nas condições C é igual ao quociente da intensidade da intervenção em $\mathrm{Pi}$ e o peso concreto de $\mathrm{Pj}$ ). $\mathrm{O}$ que demonstra que o peso concreto de um princípio é um peso relativo, já que é o peso concreto de um princípio Pi em relação a um princípio $\mathrm{Pj}$, simbolizado por ' $\mathrm{Pi}, \mathrm{j}$ '.

Para se mensurar, seria necessário um modelo numérico, que só seria possível na argumentação jurídica por analogia ${ }^{80}$. Haveria, então, diferentes possibilidades para a atribuição de números e, por questão de simplicidade, Alexy convenciona a utilização dos

\footnotetext{
${ }^{78}$ ALEXY, Robert. On Balancing and Subsumption. A structural Comparison. Ratio Juris, v. 16, n. 4, p. 433449, dez. 2003, p. 443.

${ }^{79}$ Carlos Bernal Pulido diz que neste caso, surgiria como um terceiro passo o ônus da argumentação a favor de um dos princípio, ao que Alexy chama no Posfácio ou Epílogo à sua "Teoria dos Direitos Fundamentais" de uma discricionariedade estrutural para sopesar. No entanto, como o primeiro autor aponta, Alexy parece defender duas diferentes formas de superar este tipo de empate entre pesos dos princípios (resultado igual a 1): uma no capítulo final da "Teoria dos Direitos Fundamentais", e outra, no Posfácio a esta obra, escrito quinze anos depois da sua publicação inicial, na qual Alexy aduzia argumentos que fundamentavam uma carga de argumentação a favor da liberdade e da igualdade jurídica e, posteriormente, no Posfácio, Alexy postula que, em caso de empate, prevaleceria a democracia, o que seria mais conforme ao princípio democrático. PULIDO, Carlos Bernal. La racionalidad de la ponderación. IN: CARBONELL, Miguel (Coord.). El principio de proporcionalidad y la protección de los derechos fundamentales. México, DF: Comisión Nacional de los Derechos Humanos, 2008, p. $52-53$.

${ }^{80}$ ALEXY, Robert. Teoria dos Direitos Fundamentais. Tradução de Virgílio Afonso da Silva. São Paulo: Malheiros, 2008, p. 604-605.
} 
valores $2^{0}, 2^{1}$ e $2^{2}$, como indicativo numérico das três classificações, respectivamente, $l$ indicaria o valor $1, m$ indicaria o valor 2 e $g$ indicaria o valor $4^{81}$. Em todos os casos em que $\mathrm{Pi}, \mathrm{j}$ foi maior que 1 , Pi prevalecerá sobre $\mathrm{Pj}$; sendo menor do que $1, \mathrm{Pj}$ prevalecerá sobre Pi e, sendo iguais, a lei de ponderação não definirá o princípio prevalecente. Para ilustrar: se a intensidade de intervenção em Pi for considerada séria ou grave (4) e a importância de Pj for moderada (2) o peso concreto de Pi,j será (4/2) de 2 e, portanto, Pi prevalecerá.

Alexy ainda considera outra grandeza que pode ser acrescentada à fórmula de peso, resultando em uma "fórmula de peso estendida" que, além de considerar a intensidade de intervenção de um princípio e o peso concreto de outro, adiciona o grau de segurança dos pressupostos empíricos (S) como seguro (s), plausível (p), não evidentemente falso (f), usando-se o símbolo SPiC como referente à segurança do pressuposto empírico de Pi sob condições $\mathrm{C}$ e $\mathrm{SPjC}$ a segurança do pressuposto empírico de $\mathrm{Pj}$ nas condições $\mathrm{C}$, que se relacionam com o significado que a respectiva medida tenha no caso concreto para não realização de Pi e da realização de $\mathrm{Pj}$.

Essa terceira variável S, além de I e W (intervenção e peso concreto de um princípio), concerne ao grau em que uma medida analisada implica faticamente a insatisfação do primeiro princípio e a satisfação do segundo nas circunstâncias do caso concreto ${ }^{82}$. À escala $s$, $p$ e $f$, Alexy atribui os seguintes valores $2^{0}, 2^{-1}$ e $2^{-2}$, logo se a medida for segura, seu peso será 1 , se for plausível será 0,5 e se for não evidentemente falsa será 0,25 . No caso da bebida alcoólica, poder-se-ia considerar que a aposição de alerta na embalagem seria uma medida ao menos plausível para promover a saúde $(0,5)$ e não evidentemente falsa quanto ao comprometimento da liberdade de comércio $(0,25)^{83}$.

\footnotetext{
${ }^{81}$ Alexy salienta a dificuldade dessa catalogação: "La simple catalogación de una magnitud como leve, media o grave, frecuentemente ya presenta problemas. A veces no puede distinguirse tan facilmente entre leve y grave y, en ocasiones, incluso puede parecer imposible. Las escalas jurídicas sólo pueden funcionar con umbrales relativamente difusos y esto ni siquiera ocurre así en todos los casos. La naturaleza del derecho constitucional es, en definitiva, la que establece límites al refinamiento de las escalas y excluye escalas completas de tipo infinitesimal", o que justificaria o uso dessa dotação numérica em escala geométrica, a qual se diferencia da escala aritmética pelas distâncias do grau não serem iguais, mas se incrementarem geometricamente, o que representaria o fato de que os princípios ganham cada vez uma força maior ao aumentar a intensidade da intervenção; e a escala geométrica permite definir o peso concreto de um princípio Pi não de forma diferencia $(\mathrm{Gi}, \mathrm{j}=\mathrm{IPiC}-\mathrm{WPjC})$, mas em forma e quociente: $\mathrm{GPi}, \mathrm{jC}=\mathrm{IPiC} / \mathrm{WPjC}$, daí a importância de se ter aquela escala geométrica, pois uma escala de 0 a 1, por exemplo, em um quociente, conduziria a distorções e dificultaria a percepção do peso do princípio. ALEXY, Robert. La fórmula del peso. Traducción Carlos Bernal Pulido. IN: CARBONELL, Miguel (Coord.). El principio de proporcionalidad y la protección de los derechos fundamentales. México: Comisión Nacional de los Derechos Humanos, 2008, p. 11-37, p. 26-27.

${ }^{82}$ PULIDO, Carlos Bernal. La racionalidad de la ponderación. IN: CARBONELL, Miguel (Coord.). El principio de proporcionalidad y la protección de los derechos fundamentales. México, DF: Comisión Nacional de los Derechos Humanos, 2008, p. 50-51.

${ }^{83}$ Quanto a essa última variável relativa às premissas empíricas, Carlos Bernal Pulido esclarece que tais premissas estão relacionadas ao significado que tenha a medida sob exame para os princípios relevantes (em colisão). Desta perspectiva, Pulido acrescenta que "la importancia de los principios depende de la eficiencia $(E)$,
} 
Para a aplicação do método da ponderação de Alexy, tome-se como exemplo um caso hipotético em que uma criança tenha sofrido um acidente e necessite de transfusão de sangue sob risco de morte, sem qualquer outra possibilidade de tratamento. A família da criança professa a crença dos Testemunhas de Jeová e não deseja que seja feita a transfusão que está vedada em sua religião, alegando o princípio fundamental da liberdade de crença. Neste caso, estão em colisão o direito à vida $(\mathrm{Pv})$ e a liberdade de crença $(\mathrm{Pc})$, ambos princípios assegurados no rol constitucional de direitos fundamentais.

Portanto, é mister a ponderação em sentido estrito, pois, embora a transfusão não seja medida adequada à luz da religião, é medida adequada para salvaguardar a vida da criança, passando pelo teste da adequação; também é uma medida necessária, pois não se vislumbra outro tratamento possível. Considerando-se que o caso seja levado a julgamento, pressupõe-se que a intervenção em Pv seria considerada como grave ( $\mathrm{IPvC}=4)$ e o peso abstrato da vida também considerado como sério ( $\mathrm{WPvA}=4$ ), havendo certeza quanto ao risco iminente de morte $(\mathrm{SPvC}=1)$. Por outro lado, a satisfação da liberdade de crença seria considerada como moderada $(\mathrm{WPcC}=2)$, seu peso abstrato não equiparado à vida, também seria considerado moderado $(\mathrm{WPcA}=2)$ e a segurança das premissas quanto à sua afetação (obrigatoriedade de submeter a criança a tratamento, a despeito da religião) seria considerada como certa ( $\mathrm{SPCC}=$ 1).

A fórmula de peso entre o direito à vida e a liberdade de culto seguiria o seguinte modelo: GPv,cC = IPvC . WPvA . SPvC / WPcC . WPcA . SPcC. Substituindo-se pelos números atribuídos consoante a classificação: $\mathrm{GPv}, \mathrm{cC}=4 \cdot 4 \cdot 1 / 2 \cdot 2 \cdot 1=16 / 4=4^{84}$. Assim, sendo o peso de $\mathrm{Pv}$ em relação a $\mathrm{Pc}$, maior que 1 , deve prevalecer $\mathrm{Pv}$ (direito à vida) e, portanto, justifica-se a determinação aos pais a que submetam a criança à transfusão de sangue, ainda que contrariamente a suas orientações religiosas, resolvendo-se o problema mediante a aplicação do princípio do direito à vida que, neste caso, tem por consequência jurídica a determinação de tratamento médico por transfusão.

velocidad $(V)$, probabilidad $(P)$, alcance $(A)$ y duración $(D)$ con que la medida afecta y satisface, correlativamente, los principios en juego. Cuanto más eficiente, rápido, probable, potente y duradero sea el acto bajo examen para afectar y satisfacer, correlativamente, los principios relevantes, tanto mayor será la importancia de tales principios" e, incluindo-se a segurança das premissas normativas, isso poderia levar a uma fórmula estendida praticamente inexequível, como a que propõe Pulido:

$\mathrm{GPi}, j \mathrm{C}=\underline{(\mathrm{SiPiC} \cdot \mathrm{PJPiC}) \cdot(\mathrm{EPiC} \cdot \mathrm{VPiC} \cdot \mathrm{PPiC} \cdot \mathrm{APiC} \cdot \mathrm{DPiC}) \cdot \mathrm{GPiA} \cdot(\mathrm{SEIPiC} \cdot \mathrm{SNIPiC} \cdot \mathrm{SNPPiA})}$

$(\mathrm{SiPjC} \cdot \mathrm{PJPjC}) \cdot(\mathrm{EPjC} \cdot \mathrm{VPjC} \cdot \mathrm{PPjC} \cdot \mathrm{APjC} \cdot \mathrm{DPjC}) \cdot \mathrm{GPiA} \cdot(\mathrm{SEIPjC} \cdot \mathrm{SNIPjC} \cdot \mathrm{SNPPjA})$

Naturalmente que aqui, não se fará tal grau de refinamento, atendo-se apenas à fórmula simples. PULIDO, Carlos Bernal. La racionalidad de la ponderación. IN: CARBONELL, Miguel (Coord.). El principio de proporcionalidad y la protección de los derechos fundamentales. México, DF: Comisión Nacional de los Derechos Humanos, 2008, p. 39-61, p. 60.

${ }^{84}$ PULIDO, Carlos Bernal. Estructura y límites de la ponderación. Doxa, n. 26, p. 225-238, 2003, p. 229. 
Nesse, como em outros casos de colisão de princípios, seria necessária a aplicação do método da ponderação de Alexy, uma vez que, constatado o conflito de princípios, não estaria determinada a premissa normativa para se valer da subsunção e, ademais, como assevera Luis Prieto Sanchís, não há uma orientação constitucional acerca de como se decidir ${ }^{85}$.

No entanto, a própria atribuição de valores numéricos correspondentes aos supostos valores de que estão carregados os princípios em conflito levanta a séria objeção quanto à racionalidade de tal procedimento, já que a escolha poderia ser aleatória, subjetiva e mesmo arbitrária, o que enseja diversas críticas à proposta teórica de Alexy, apresentadas na sequência, bem como as respostas possíveis a tais objeções.

\subsubsection{Críticas ao método da ponderação}

Quanto à teoria dos princípios de Alexy são apontados sete grupos de objeções: objeções teórico-normativas; teórico-argumentativas; doutrinárias; institucionais; teóricointerpretativas; de validade teórica; e, finalmente, teórico-científicas ${ }^{86}$. As primeiras dizem respeito ao questionamento da própria existência de princípios jurídicos e se podem ser distinguidos das regras, uma vez que fossem efetivamente normas jurídicas, ou se tal distinção não estaria equivocada.

As objeções teórico-argumentativas questionam se a ponderação é propriamente um tipo de argumento racional ou seria um método irracional. Já as críticas doutrinárias apontam que a construção de abordagens de princípio poderia constituir um perigo para os direitos constitucionais, uma vez que construções de princípio poderiam eliminar a validade estrita de regras. Por outro lado, a objeção institucional argumenta no sentido de a tese da otimização ocasionar uma proliferação de direitos constitucionais, implicando uma hiperconstitucionalização do sistema jurídico, com um desvio do estado legislativo para o estado constitucional adjudicativo ${ }^{87}$.

\footnotetext{
${ }^{85}$ Nas palavras do autor: "la Constitución no nos proporciona orientación alguna para decidir por debajo de qué umbral de satisfacción hemos de considerar vulnerados dichos mandatos constitucionales". SANCHÍS, Luis Prieto. El juicio de ponderación constitucional. IN: CARBONELL, Miguel (Coord.). El principio de proporcionalidad y la protección de los derechos fundamentales. México, DF: Comisión Nacional de los Derechos Humanos, 2008, p. 77-113, p. 84.

${ }^{86}$ ALEXY, Robert. The construction of constitutional rights. Law \& Ethics of Human Rights. v. 4, n. 1, p. 20-32, 2010, passim.

87 Essa hiperconstitucionalização poderia ainda ter o efeito contraposto do esvaziamento da importância dos princípios constitucionais por sua vulgarização mediante aplicação a matérias de importância secundária. A crítica institucional, especialmente da doutrina constitucionalista ainda aponta para outro perigo: a inobservância do princípio da separação dos poderes pela invasão de uma função do Estado no campo competencial de outro. Isso seria resultado da judicialização da política, mediante transferência ao Poder Judiciário da apreciação de
} 
As objeções teórico-interpretativas questionam se e como as construções com base em princípios poderiam ser estabelecidas como uma interpretação correta de um catálogo de direitos constitucionais tal como entendidos no direito positivo. As objeções relativas à validade teórica reprovam a teoria dos princípios por expor a risco a hierarquia superior da Constituição.

Finalmente, as objeções teórico-científicas consideram que a teoria dos princípios, em razão de sua abstração, nada diz, já que não é dotada de poder diretivo para as decisões a serem futuramente tomadas, o que implica que a teoria dos princípios não é suficiente como uma teoria de direitos constitucionais ${ }^{88}$.

A despeito de todas essas objeções, as de maior relevo dizem respeito especialmente à irracionalidade do método da ponderação que decorreria de diversas razões, mas principalmente da indeterminação da ponderação, pela incomensurabilidade enfrentada em sua aplicação e, logo, a impossibilidade de prever resultados.

A indeterminação da ponderação decorreria da inexistência de critérios jurídicos para a definição de valores que garantissem objetividade da ponderação e que fossem vinculantes para o juiz, podendo ser usados para se controlar decisões em que os julgadores se valham desse método, que acabaria sendo mero subterfúgio retórico cuja utilidade seria justificar todo tipo de decisões judiciais, sendo, por conseguinte, um mecanismo arbitrário ou salomônico e, por tal razão, ilegítimo para ser empregado por um Tribunal Constitucional ${ }^{89}$.

A incomensurabilidade ocorreria dada a inexistência de uma organização hierárquica dos princípios submetidos à ponderação, bem como não haveria uma medida comum entre eles, o que os tornaria duas magnitudes incomparáveis. Em decorrência desses fatores, um terceiro motivo para a crítica à ponderação é de que seria irracional, em razão da impossibilidade de previsão de seus resultados, pois todos os resultados atingidos seriam particulares, uma vez que dependentes das circunstâncias do caso e não de critérios gerais,

\footnotetext{
questões de caráter político, cuja análise seria, em regra, de competência dos poderes Executivo e Legislativo, como uma decorrência da própria Constituição Federal de 1988, vazada em princípios e conceitos abertos, o que poderia implicar a politização da justiça, já que o Poder Judiciário procederia a apreciações de natureza política. O risco seria ainda do ativismo judicial, consistente na extrapolação dos limites legais. Quanto a tais temas, vide: FERREIRA FILHO, Manoel Gonçalves. Aspectos do Direito Constitucional Contemporâneo. 2. ed. São Paulo: Saraiva, 2009; e, RAMOS, Elival da Silva. Parâmetros dogmáticos do ativismo judicial em matéria constitucional. Tese apresentada à Faculdade de Direito da Universidade de São Paulo para inscrição em concurso público visando ao provimento de cargo de professor titular. São Paulo, 2009.

${ }^{88}$ Tais objeções e as respostas, Alexy expõe em: ALEXY, Robert. The construction of constitutional rights. Law \& Ethics of Human Rights. v. 4, n. 1, p. 20-32, 2010.

${ }^{89}$ PULIDO, Carlos Bernal, La racionalidad de la ponderación. IN: CARBONELL, Miguel (Coord.). El principio de proporcionalidad y la protección de los derechos fundamentales. México, DF: Comisión Nacional de los Derechos Humanos, 2008, passim.
} 
formando uma jurisprudência ad hoc que tenderia a enfatizar a justiça do caso concreto, mas sacrificaria a certeza, a coerência e a generalidade do Direito.

O que evidencia a conexão entre essas objeções: a impossibilidade de prever resultados da ponderação decorreria de sua falta de precisão conceitual em razão da inexistência de uma única medida que possibilitasse determinar o peso dos princípios relevantes em cada caso concreto ${ }^{90}$.

No mesmo sentido, J. J. Moreso ${ }^{91}$ lança críticas à atribuição de peso aos princípios, por entendê-la como prioritariamente subjetiva e arbitrária. Quanto ao peso abstrato, o autor entende que seria necessária uma clareza de ordenação abstrata dos direitos que permitisse ter certeza acerca do peso abstrato de um princípio. No entanto, tal escala não existe e Alexy não teria estabelecido nenhum critério para a determinação desse peso. Tampouco estaria clara qual seria uma forma de escala abstrata para tal tarefa.

O mesmo ocorreria quanto à classificação de uma intervenção como leve, moderada ou grave, a qual não oferece parâmetros a respeito de como utilizar essa escala, ou seja, não há predeterminação do que define uma intervenção como leve, qual seria o padrão objetivo que permitisse constatar ser outra intervenção grave; até porque uma intervenção que pudesse ser extremamente grave em uma sociedade poderia ser leve em outra - um exemplo seria o uso de crucifixo em espaços públicos, o que poderia ser ou uma exigência ou uma ofensa à liberdade de crença, a depender do regime teocrático ou democrático.

A crítica, portanto, é de que apenas é possível construírem-se escalas numéricas quando se está em presença de uma propriedade claramente definida tal como no caso do teste objetivo citado por Moreso para se comparar a dureza de um mineral: o mais duro é o que pode quebrar o menos duro e este não pode partir aquele. Um teste empírico permitiria traçar uma escala numérica para o grau de dureza aferida por meio desse teste. Diferentemente, no caso da ponderação de princípios, os pesos atribuídos, embora sejam relativos - mediante seu sopesamento com outros princípios colidentes - não permitem uma aferição empírica, senão razões a favor e contra.

A terceira linha de questionamento de Moreso parte da assimilação do método de ponderação de Alexy como referente a um caso individual, que levaria ao referido problema da concepção ad hoc de ponderação, o que implicaria um modelo decisório particularista, de

\footnotetext{
${ }^{90}$ PULIDO, Carlos Bernal, La racionalidad de la ponderación. IN: CARBONELL, Miguel (Coord.). El principio de proporcionalidad y la protección de los derechos fundamentales. México, DF: Comisión Nacional de los Derechos Humanos, 2008, p. 41.

${ }^{91}$ MORESO, José Juan. Alexy y la aritmética de la ponderación. IN: CARBONELL, Miguel (Coord.). El principio de proporcionalidad y la protección de los derechos fundamentales. México: Comisión Nacional de los Derechos Humanos, 2008, p. 63-75, passim.
} 
modo que uma única propriedade diferente entre casos semelhantes poderia implicar solução diversa para o caso.

Essa crítica é reforçada por Manuel Garcia Amado, ao dizer que nem mesmo o sistema métrico utilizado em um caso seria usado em outro e, uma vez que os princípios não possuem em si um "peso objetivo", a atribuição de um valor variaria conforme as orientações pessoais do julgador, constituindo-se em um expediente para determinar resultados que mais lhes agradassem, de acordo com orientações pessoais ${ }^{92}$. Levantando-se a questão a respeito de a ponderação ser ou não um método passível de controle racional.

Embora factualmente a atribuição de valorações como a consideração de uma intervenção em um princípio ou importância do princípio oposto como leve, moderada ou grave não conte com um critério objetivo que determine de antemão o valor a ser atribuído às variáveis da fórmula de peso e, portanto, admita considerações subjetivas, Carlos Pulido considera as críticas apontadas como "hiperracionais" e, por tal razão, "irracionais". O autor convém em que a ponderação tenha caráter formal e que não possa excluir apreciações subjetivas do juiz, mas nega que, por isso, seja irracional e que esteja exclusivamente pautada por orientações subjetivas.

A hiperrracionalidade das críticas decorreria de uma exigência de objetividade da ponderação que não existiria nem nas controvérsias sobre princípios e nem no âmbito normativo de maneira geral, pois apenas seria alcançável em um sistema jurídico ideal, dotado de exatidão absoluta e objetividade, o que não seria possível, dada a já mencionada indeterminação da própria linguagem em geral e da jurídica em particular; e tampouco seria desejável uma perfeita objetividade, pois uma sociedade que dispusesse de um catálogo de princípios jurídicos totalmente determinados limitaria significativamente as possibilidades de deliberação política, dificultando a adaptação do direito a novas necessidades sociais ${ }^{93}$.

\footnotetext{
${ }^{92}$ Em uma crítica acerba, Garcia Amado aponta que "El problema, evidentemente, es que si ya de por sí los principios son fórmulas cuyo contenido unívoco previo a su determinación por el intérprete de turno es más que dudoso, y si, además, el intérprete no sólo tiene que decidir qué contenido relevante para un caso concreto va implicado en un principio, sino también conciliar ese principio en la proporción adecuada com un principio de contenido opuesto, no acierto a imaginarme que pueda existir en esas operaciones el más mínimo grado de objetividad y no la pura, simple y descarnada discrecionalidad, camuflada, eso sí, bajo ese elegante expediente metodológico de decir que la decisión recae como resultado de un objetivo e imparcial 'pesaje' de los principios en pugna, de modo que hay de cada uno la proporción que corresponde a su peso en la balanza (que ni siquiera es una balanza idéntica para todos los casos, ya que es el propio caso el que determina el sistema métrico o la balanza con la que en esa ocasión los principios se van a medir; tercera vía de entrada de la discrecionalidad, por tanto)". AMADO, Juan Antonio García. Ductibilidad Del derecho o exaltación Del juez? Defensa de la ley frente a (otros) valores y princípios. Anuario de Filosofía Del Derecho, v. 13, p. 65-85, 1996, p. 70-71.

${ }^{93}$ PULIDO, Carlos Bernal. La racionalidad de la ponderación. IN: CARBONELL, Miguel (Coord.). El principio de proporcionalidad y la protección de los derechos fundamentales. México, DF: Comisión Nacional de los Derechos Humanos, 2008, p. 43-44.
} 
Não obstante, para tentar superar a alegada impossibilidade de controle racional da ponderação no modelo apresentado por Alexy, Moreso propõe a observância de etapas que confeririam racionalidade à ponderação. A primeira etapa consistiria na delimitação do problema normativo, ou seja, não o conjunto das ações humanas possíveis, mas um conjunto de ações mais reduzido, o universo do discurso nos termos de Alchourrón e Bulygin que, no caso da transfusão de sangue diria respeito a orientações religiosas que impedem certos tratamentos médicos, expondo a risco a vida de uma pessoa.

Na segunda etapa, seriam identificadas pautas prima facie aplicáveis a tal âmbito de ações, no caso o princípio que estabelece o direito à vida e a liberdade de crença. Na terceira etapa, seriam considerados casos paradigmáticos, reais ou hipotéticos, do âmbito normativo selecionado, com a finalidade de restringir o campo de reconstruções admissíveis (o que aprece assemelhar-se à proposta de coerentista de Susan Hurley explanada a seguir em 2.2.4).

$\mathrm{Na}$ quarta etapa, seriam estabelecidas as propriedades relevantes do universo do discurso com o fito de determinar as soluções normativas; no caso da transfusão de sangue a inexistência de outro meio de tratamento seria uma propriedade relevante. Na quinta e última etapa seriam formuladas regras que resolvessem de modo unívoco todos os casos do universo do discurso, as quais estariam sob controle de acordo com sua capacidade de reconstruir casos paradigmáticos ${ }^{94}$.

No entanto, essa postulação não resolveria os problemas apontados, já que cabe ao juiz decidir em cada uma das etapas, determinando, qual o universo de casos, os princípios aplicáveis, as propriedades relevantes, os casos paradigmáticos, de modo que, por exemplo, se um juiz considerar como relevante uma propriedade que outro não tenha considerado, isso poderia alterar a decisão, o que demonstra que também não há critérios cabais para se determinar o que é ou não relevante na decisão de um caso. Isso, a despeito do esforço de Moreso, leva-o a concluir seu modelo confirmando que são necessárias escolhas, pois duas ou mais reconstruções alternativas são possíveis ${ }^{95}$.

Conforme aponta Alexy ${ }^{96}$, Jürgen Habermas critica o método da ponderação, por considerar que a ponderação não seria racional e, pois, tampouco objetiva, pelas seguintes razões: não haveria padrões racionais para o sopesamento, e, portanto, seria um procedimento

\footnotetext{
${ }^{94}$ MORESO, José Juan Alexy y la aritmética de la ponderación. IN: CARBONELL, Miguel (Coord.). El principio de proporcionalidad y la protección de los derechos fundamentales. México: Comisión Nacional de los Derechos Humanos, 2008, p. 63-75, p. 71-73.

${ }_{95}$ MORESO, José Juan Alexy y la aritmética de la ponderación. IN: CARBONELL, Miguel (Coord.). El principio de proporcionalidad y la protección de los derechos fundamentales. México: Comisión Nacional de los Derechos Humanos, 2008, p. 63-75, p. 74-75.

${ }^{96}$ ALEXY, Robert. Constitutional Rights, Balancing and Rationality. Ratio Juris, v. 16, n. 2, p. 131-140, jun. 2003, p. 134-135.
} 
arbitrário ou baseado em costumes irrefletidos, como apontado acima. E, ainda, a ponderação privaria os direitos constitucionais de seu poder normativo, por sua redução ao nível de objetivos, políticas e valores, de modo que esses direitos perderiam a estrita prioridade característica de pontos de vista normativos, pois se retirariam as regras jurídicas do âmbito de conceitos definidos como certo e errado, correto e incorreto, levando a um julgamento valorativo.

Alexy considera que se o sopesamento fosse por sua natureza irracional, também os princípios jurídicos, como mandamentos de otimização, seriam irracionais. Isso, para ele, não ocorre, porque haveria padrões que assegurariam a racionalidade de tal método por meio da referência ao grau de interferência em um princípio e o grau de importância de outro, bem como a relação entre ambos, estabelecida pela fórmula de peso ${ }^{97}$, o que demonstraria uma exigência de correção, por meio da demonstração do peso atribuído a cada princípio como justificação para a tomada de decisão em certo sentido. Assim, apenas haveria uma aplicação irrefletida e arbitrária de princípios por meio da ponderação se o processo adjudicativo fosse realizado fora da estrutura da argumentação, a qual se trata de mecanismo público de controle $^{98}$.

Ademais, quanto à alegação de que haveria meros padrões a que julgadores estariam acostumados, Alexy entende que haveria correção desse argumento de Habermas apenas se o sentido da decisão tomada proviesse unicamente da existência de uma linha de precedentes e não de sua própria correção, a qual seria garantida pelos marcos da argumentação, sendo possível um discurso racional pautado pelas ideias regulativas do que é correto da perspectiva da Constituição, o que tornaria possível uma comensurabilidade da ponderação por meio da escala, embora artificialmente estabelecida, que determina os graus para as valorações dos princípios $^{99}$.

No mesmo sentido, para Carlos Pulido a ponderação seria racional, inclusive, pelo fato de que sua estrutura reconhece os limites de sua própria racionalidade, já que a fórmula de peso não determina por si mesma o grau de intervenção nem o de satisfação dos princípios em colisão e tampouco determina as demais variáveis (peso abstrato e grau de segurança das

\footnotetext{
${ }^{97}$ A respeito da fórmula de peso: "La estructura que expresa la fórmula del peso no sería una estructura racional si su in put fuesen premisas que la expulsaran del ámbito de la racionalidad. No es ese, sin embargo, el caso. El in put que representan los números son juicios. Este juicio expresa una pretensión de corrección que, dentro del discurso, puede ser justificada como la conclusión de otro esquema de inferência". ALEXY, Robert. Ponderación, control de constitucionalidad y representación. In: IBÁÑEZ, Perfeto Andrés; ALEXY, Robert. Jueces y ponderación argumentativa. México: Universidad Federal Autónoma de México, 2006, p. 1-18, p. 9-10. ${ }^{98}$ Idem, ibidem, p. 136 e 139.

99 ALEXY, Robert. Teoria dos Direitos Fundamentais. Tradução de Virgílio Afonso da Silva. São Paulo: Malheiros, 2008, p. 18 e 24.
} 
premissas empíricas), de modo que cabe ao juiz o dever de determinar os pesos, preenchendo as variáveis da fórmula de peso ${ }^{100}$.

O que, naturalmente, abriria espaço para o arbítrio e o voluntarismo, mas, na linha de Alexy, Pulido aponta como mecanismo para afastar a arbitrariedade possível na definição dos pesos, bem como uma forma de observância da exigência de correção das decisões tomadas, o ônus da argumentação que tem o juiz, no sentido de justificar os valores por ele atribuídos aos princípios $^{101}$.

Ademais, o fato de a decisão ter sido tomada em um caso concreto não significaria que fosse ad hoc, já que a mesma decisão deveria ser tomada em outros casos, por seu caráter precedencial $^{102}$, a menos que outras propriedades relevantes fossem consideradas; o que, mesmo no caso da subsunção, poderia levar a uma alteração da solução jurídica do caso ${ }^{103}$.

Em cotejamento entre os métodos subsuntivo e da ponderação, Alexy lembra que da perspectiva do método subsuntivo, a racionalidade de uma estrutura inferencial depende essencialmente da conexão das premissas, enquanto na fórmula de peso as premissas são representadas por números que correspondem a julgamentos com exigência de correção, atendida por meio da justificação argumentativa ${ }^{104}$.

Quanto à dificuldade de os números serem apenas representações de preferências pessoais, não havendo critérios objetivos para a definição de qual o valor ou "peso" a ser atribuído aos princípios em colisão, Alexy argumenta que isso não implicaria irracionalidade,

${ }^{100}$ Daí porque Riccardo Guastini diz que “... la ponderación implica el ejercicio de un doble poder discrecional de parte del juez constitucional. Es una operación discrecional la creación de una jerarquía axiológica entre los principios en cuestión. Y es igualmente una operación discrecional la mutación de valores comparativos de los dos principios a la luz de una nueva controversia a resolver". GUASTINI, Riccardo. Ponderación: un análisis de los conflictos entre principios constitucionales. Palestra del Tribunal Constitucional Revista mensual de jurisprudencia, Lima, a. 2, n. 08, p. p. 631-637, ago. 2007, p. 637.

${ }_{101}$ PULIDO, Carlos Bernal. La racionalidad de la ponderación. In: CARBONELL, Miguel (Coord.). El principio de proporcionalidad en el Estado constitucional. Bogotá: Universidad Externado de Colombia, 2007, p. 51-80, 2007, p. 284 et. seq.

102 Conforme Marcelo de Souza: "a decisão de um caso tomada anteriormente pelo Judiciário constitui, para os casos a ele semelhantes, um precedente judicial. Daí se vê, sem maior esforço, que o precedente judicial existe em qualquer sistema jurídico. SOUZA, Marcelo Alves Dias de. Do precedente judicial à súmula vinculante. 1 . ed. 3. reimp. Curitiba: Juruá, 2008, p. 51.

103 "Finalmente, es preciso enfatizar que la ponderación es un tipo racional de pensamiento, bien conocido y utilizado en diversas áreas de la reflexión humana, que no conduce a una jurisprudencia ad hoc [...] En estos casos futuros, al Tribunal Constitucional le basta llevar a cabo una subsunción del caso bajo el supuesto de hecho de las normas adscritas concretadas en sentencias anteriores [...] No necesita llevar a cabo una nueva ponderación, a menos que sea necesario modificar el sentido de los precedentes. Ahora bien, estas mismas consideraciones se aplican en relación con la atribución de las magnitudes correspondientes a las variables de la fórmula del peso. La red de precedentes otorga previsibilidad a los resultados de la ponderación e integra en una unidad normativa a la jurisprudencia del Tribunal Constitucional y a las disposiciones de los derechos fundamentales". PULIDO, Carlos Bernal. La racionalidad de la ponderación. In: CARBONELL, Miguel (Coord.). El principio de proporcionalidad en el Estado constitucional. Bogotá: Universidad Externado de Colombia, 2007, p. 51-80, 2007, p. 286-287.

${ }^{104}$ ALEXY, Robert. The construction of constitutional rights. Law \& Ethics of Human Rights. v. 4, n. 1, p. 2032,2010 , p. 32. 
já que até mesmo, na aplicação de uma lei pelo método subsuntivo, poderia haver variações. O que garantiria a racionalidade e objetividade - esta entendida como um meio termo entre a certeza e a arbitrariedade -, seria a justificação argumentativa ${ }^{105}$.

Portanto, a saída de Alexy para o problema da arbitrariedade, exige uma teoria da argumentação subjacente capaz de conferir racionalidade e objetividade à decisão, teoria na qual as mesmas questões acerca da orientação subjetiva ou ideológica do julgador surgirão. No entanto, a discussão sobre a capacidade da teoria da argumentação de Alexy ou de outra proposta teórica de racionalidade argumentativa para superar essas dificuldades foge ao escopo do presente trabalho.

105 "But contestability does not imply irrationality. If this were the case, not only balancing, but legal reasoning as such would be for the most part irrational. Precisely the opposite, however, is the case. Justifiability, despite the fact that it cannot be identified with provability, implies rationality, and, with it, objectivity, understood as lying between certainty and arbitrariness". ALEXY, Robert. The construction of constitutional rights. Law \& Ethics of Human Rights. v. 4, n. 1, p. 20-32, 2010, p. 32. 


\section{MODELOS COERENTISTAS}

\subsection{CONSIDERAÇÕES GERAIS SOBRE MODELOS COERENTISTAS NO DIREITO}

Consoante exposto, ante casos difíceis em que há conflito de princípios, o método dedutivo não permite se chegar à solução, pois não estão claras as premissas a se aplicar. Daí ser pertinente a proposta de Alexy de se aplicar o método da ponderação de princípios, a fim de se aferir o princípio prevalecente no caso concreto.

Contudo, o desconforto que essa metodologia enseja é de que há certa ‘imponderabilidade’ entre a ponderação de princípios e a vinculação à lei, já que a prevalência de um princípio e não de outro acaba implicando a observância e não observância simultânea da lei. Os modelos coerentistas entram em jogo justamente como mecanismos que auxiliam no equacionamento desse problema.

Isso porque o coerentismo funciona como critério de justificação das decisões judiciais e permite - especialmente como explorado na versão de Susan Hurley a seguir (2.2.4) explanada, reforçada pelo modelo inferencial - que na ponderação de princípios o julgador tenha em vista situações semelhantes já ponderadas pelo legislador e, nesta medida, as pautas legais poderiam auxiliar na aplicação do Direito ao caso concreto com vinculação à lei.

As teorias coerentistas não são exclusividade do âmbito jurídico ${ }^{106}$. Mas nesse campo, que é o de relevo para o presente estudo, surgem como critério para justificar os resultados alcançados no processo de sopesamento de princípios jurídicos conflitantes. A proposta das teorias coerentistas no Direito, conforme Amalia Amaya ${ }^{107}$, está ligada à emergência do paradigma pós-positivista. Elas representam um esforço de redesenhar a configuração do Direito e da justificação jurídica defendida pelo positivismo jurídico que, especialmente em

\footnotetext{
${ }^{106}$ Segundo Amalia Amaya: "In recent decades, coherence has been in vogue in a number of different domains. There have been advocates of coherence theories of epistemic justification (BonJour 1985; Lehrer 2000). Coherence theories of truth have been proposed as a main alternative to the traditional correspondence theory of truth (Walker 1989). It has also been argued that coherentist standards govern theory-construction as well as theory-choice in science (Thagard 1992). Coherence has been claimed to be a central criterion for determining not only what we are justified in believing, but also what we are justified in doing [...] Prominent accounts of moral deliberation have sought to defend ethical principles on the basis of their coherence with particular ethical judgments (Rawls 1999; Goldman 1988; DePaul 1993). And psychologists and linguists have employed the concept of coherence to help understand processes as diverse as impression formation (Kunda 1999), discourse interpretation (Hellman 1995), or analogical mapping (Holyoak and Thagard 1995). In law, coherence theories have been very popular as well. Coherentist approaches to law and adjudication have been extremely influential in contemporary legal theory". AMAYA, Amalia. Legal Justification by Optimal Coherence. Ratio Juris, v. 24, n. 3, p. 304-329, sep. 2011, p. 304-305.

107 AMAYA NAVARRO, Amalia. An inquiry into the nature of coherence and its role in legal argument. $\mathrm{PhD}$ Theses. Department of Law. European University Institute, 2006.
} 
suas versões fortes, retrata a justificação jurídica e o Direito como baseados em regras e autônomos.

Nas visões coerentistas, por sua vez, a justificação no Direito vai além de justificação dedutiva e está intimamente ligada a outras formas de razão prática, tais como a justificação moral $^{108}$. Assim, mesmo nos casos controversos, em que o positivismo jurídico em suas versões fortes postula que, quando as regras são insuficientes e o raciocínio dedutivo não provê uma diretriz determinante, os juízes têm discrição forte, as teorias coerentistas defendem que há constrangimentos epistêmicos sobre essa discricionariedade dados por razões de coerência.

No entanto, as teorias coerentistas no Direito não chegam a consenso sobre critérios, por isso a colocação no plural de 'modelos coerentistas', e há certas nuanças entre as propostas coerentistas. Nesse sentido, podem-se classificar as teorias coerentistas como fracas ou fortes. As teorias coerentistas 'fracas' postulam que a coerência é uma condição necessária, mas não suficiente da justificação jurídica, uma vez que outros elementos são necessários para a justificação, tais como argumentos consequencialistas na proposta de MacCormick a ser a seguir exposta (2.2.1).

Já as teorias coerentistas fortes defendem que a coerência é uma condição necessária e suficiente para a justificação jurídica, e é considerada uma base que compreende tanto regras jurídicas como princípios de moralidade política, de maneira que uma decisão é considerada justificada em virtude de sua coerência tanto com o direito posto quanto com padrões morais, o que indica maior afastamento das visões positivistas fortes que postulam distanciamento entre direito e moral.

Conforme salienta Amalia Amaya ${ }^{109}$ a motivação da teoria coerentista, tanto na versão fraca como na forte, deve ser localizada no contexto de uma crítica não cética do positivismo jurídico ${ }^{110}$, já que as versões fracas de coerência tentam suplementar o positivismo ao dirigir a atenção a materiais jurídicos outros que não apenas regras jurídicas; mas as versões mais fortes vão além na sua crítica do paradigma positivista, podendo-se considerá-las como fornecedoras de uma visão alternativa sobre o conceito de direito.

\footnotetext{
${ }^{108}$ Grande parte das teorias coerentistas acaba recorrendo à moral, conforme se notará. Mas isso não é uniforme, tanto assim, que se notará na proposta de Juliano Maranhão uma busca de refutar esse paradigma. Mais um motivo para se falar de "modelos coerentistas", visto não haver unanimidade das linhas teóricas.

${ }^{109}$ AMAYA NAVARRO, Amalia. An inquiry into the nature of coherence and its role in legal argument. $\mathrm{PhD}$ Theses. Department of Law. European University Institute, 2006.

${ }^{110}$ Entre as alternativas céticas ao formalismo jurídico estão as vertentes do realismo jurídico e movimentos críticos. Já o coerentismo é versão não cética justamente por sua crença na razão e, sobretudo, na possibilidade de se ampliar a razão no Direito, sobretudo em casos difíceis.
} 
Quanto ao papel da coerência na justificação jurídica, há divergência se seria mais adequada uma abordagem 'local' ou 'global'. Segundo o modelo de coerência 'local', uma decisão jurídica está justificada se é coerente com os princípios que melhor explicam uma área particular do Direito. Por outro lado, para um modelo 'global', a justificação em uma decisão jurídica depende de sua coerência com o sistema jurídico como um todo e não apenas com um ramo dele ${ }^{111}$. Essa distinção é das que provocam mais amplas discussões.

Joseph Raz $^{112}$ considera o modelo de coerência global como equivocado por duas razões importantes: primeiramente porque as abordagens coerentistas globais subestimam o valor pluralismo e idealizam o Direito em um contexto que desconsidera a concretude da política e suas divergências, e mesmo incoerências, que são sancionadas pela moralidade das instituições normativas.

Ele reconhece que a existência de visões inconsistentes sobre moral, religião, questões sociais e políticas em sociedades democráticas tem implicações sobre o Direito, na medida em que tende a levar a regras e princípios jurídicos que os reflitam, o que pode ocasionar dilemas jurídicos concretos. Por essa razão, Raz defende um modelo coerentista local, não comprometido, portanto, com a coerência de todo o sistema jurídico, mas apenas dos ramos inerentes ao problema do caso ${ }^{113}$.

Adotando essa mesma estratégia para compatibilizar o coerentismo com o pluralismo, Leonor Soriano ${ }^{114}$ postula uma abordagem coerentista local, mas aponta os problemas de ambas as abordagens, local e global, relativos à tensão entre a autoridade e a moralidade (na acepção de coerência) do Direito; o fato de uma teoria coerentista apropriada ter de lidar com o valor pluralismo, sem tentar reduzir os valores conflitantes a um sistema de princípios; e o fato de a coerência na justificação não dever ser exclusivamente dependente da noção de coerência no Direito.

\footnotetext{
${ }^{111}$ Amalia Amaya ainda salienta a diferença da classificação da coerência como local ou global, em relação à coerência sistêmica ou relacional. Modelos coerentistas relacionais defendem que a justificação implica que uma decisão jurídica é coerente com um corpo de normas, as quais não precisam ser coerentes; em detrimento de modelos sistêmicos de coerência que defendem que a justificação é uma questão de pertencer a um corpo de normas coerentes. AMAYA NAVARRO, Amalia. An inquiry into the nature of coherence and its role in legal argument. PhD Theses. Department of Law. European University Institute, 2006, p. 130.

${ }_{112}^{12}$ RAZ, Joseph. The relevance of coherence. Boston University Review, v. 72, n. 2, p. 273-231, mar. 1992.

${ }^{113}$ No mesmo sentido, Barbara Levenbook entende que "Coherence [. . .] is not always to be achieved to the whole system of established law in the jurisdiction in question [. . .] Sometimes coherence is to be achieved only to a subset, to a group of legal standards and decisions constituting a branch of law. This is a much more manageable task than achieving global coherence, and one that judges with limitations of knowledge and time can be expected to achieve (Levenbook 1984, 371)". LEVENBOOK, Barbara. The Role of Coherence in Legal Reasoning Apud SORIANO, Leonor Moral. A Modest Notion of Coherence in Legal Reasoning. A Model for the European Court of Justice. Ratio Juris, v. 16, n. 3, p. 296-323, sep. 2003, p. 299.

${ }^{114}$ SORIANO, Leonor Moral. A Modest Notion of Coherence in Legal Reasoning. A Model for the European Court of Justice. Ratio Juris, v. 16, n. 3, p. 296-323, sep. 2003.
} 
Aqui é preciso remeter à distinção que a autora faz entre teorias coerentistas no sistema jurídico e teorias coerentistas na justificação jurídica ou adjudicação. As primeiras focam no ajuste da decisão ao sistema jurídico e na coerência de todos os componentes do sistema jurídico. Já as teorias coerentistas da justificação jurídica focam em argumentos e como eles estão conectados ${ }^{115}$, ou seja, essas teorias de coerência na adjudicação focam em como formar acumulações, cadeias ou redes de razões.

A autora propõe, diferentemente das noções de coerência local e global, uma noção de coerência modesta que objetiva explicar a coerência na justificação jurídica. Essa noção modesta é proposta como critério indeterminado de correção, dotado de menos conteúdo normativo em nome da maior operacionalidade. $\mathrm{O}$ atributo modesta deve-se ao fato de ser um critério indeterminado de correção incapaz de prover uma resposta última para todo caso; e a caracterização como operativa, é porque a concepção permite que alguém decida levando em conta simultaneamente valores, princípios e regras e atentando ao caso particular ${ }^{116}$.

Igualmente, dentro da perspectiva de uma teoria coerentista 'naturalizada', como a proposta por Amalia Amaya ${ }^{117}$, postula-se a identificação da base de coerência de uma forma consistente com o que julgadores humanos são capazes de alcançar, ficando excluídos quaisquer modelos globais de coerência. Entretanto, segundo a autora, a melhor forma de identificar a base de coerência não é endossar um modelo de coerência 'local' no lugar de 'global'. Em vez disso, uma determinação 'contextual'118 da base seria, para ela, mais apropriada para os propósitos de justificação jurídica.

A noção de coerência modesta de Soriano, como exposto, também atenta ao caso particular e tem como ponto de partida a defesa da correção na adjudicação, focando em argumentos como principal instrumento da adjudicação. Na esteira de Alexy, Soriano aponta dois aspectos da exigência de correção na argumentação: uma decisão judicial é considerada correta se justificada conforme o Direito válido, que deve ser racional e equitativo. Há, pois, o aspecto formal da validade jurídica e o substancial da racionalidade e equidade.

Essa exigência de correção estaria justificada por refletir uma pretensão de justificabilidade, no sentido de que a justificação jurídica é a atividade racional de dar razões

\footnotetext{
115 SORIANO, Leonor Moral. A Modest Notion of Coherence in Legal Reasoning. A Model for the European Court of Justice. Ratio Juris, v. 16, n. 3, p. 296-323, sep. 2003, p. 296-297.

${ }^{116}$ SORIANO, Leonor Moral. A Modest Notion of Coherence in Legal Reasoning. A Model for the European Court of Justice. Ratio Juris, v. 16, n. 3, p. 296-323, sep. 2003, p. 305-306.

117 AMAYA NAVARRO, Amalia. An inquiry into the nature of coherence and its role in legal argument. $\mathrm{PhD}$ Theses. Department of Law. European University Institute, 2006.

118 Sobre a determinação contextual, vide: AMAYA, Amalia. Diez Tesis Acerca de la Coherencia em el Derecho. In: ATIENZA, Manuel (Ed.). Discusiones $X$ - la coherencia en el Derecho. Buenos Aires: Universidad Nacional Del Sur, dez. 2011, p. 21-64.
} 
para sustentar a correção formal e substancial de uma decisão particular. E a noção modesta de coerência focaria em como construir estruturas de argumentos sustentadores coerentes, consoante uma perspectiva pluralista, uma vez que juízes seriam instruídos a levar em conta todas as razões relevantes ${ }^{119}$, como citado.

Daí porque a noção de coerência modesta não provê respostas conclusivas, pois são admitidas diversas soluções razoáveis ao mesmo caso, inclusive, a justificação judicial pode ser coerente em um momento e não mais em outro pela inserção de novas regras e princípios em um sistema normativo ${ }^{120}$.

Assim, embora as teorias coerentistas sejam uma alternativa para se assegurar padrões de justificação jurídica e racionalidade decisória, não têm o condão de resolver todos os problemas jurídicos, até mesmo pelas limitações que podem ser indicadas a seu respeito: a vagueza da noção de coerência; o problema do ajuste de razões autoritativas; sua confiança na comensurabilidade de valores e o compromisso de algumas teorias coerentistas com um modelo de justificação, que segundo Amaya ${ }^{121}$, é psicologicamente implausível (por abarcar elementos para além da cognoscibilidade efetiva de pessoas).

Dessa maneira, as teorias coerentistas enfrentam dificuldades na superação do positivismo e da postulação de um mecanismo de decisão racional, a começar pelo fato de essas teorias propugnarem que, mesmo nos casos difíceis, os julgadores estão vinculados a decidir conforme o Direito - que abarca não apenas padrões sociais, mas também princípios relevantes de moralidade. Isso poderia levar à objeção de que teorias coerentistas, em vez de diminuírem, poderiam aumentar a discrição judicial, e então ocasionariam indeterminação jurídica, pois a busca de coerência no sentido global poderia levar a uma (re)construção arbitrária do direito.

Ainda, ao se inserirem razões morais como definidoras de qual decisão é mais bem justificada, são levantadas dúvidas se o modelo coerentista reconhece o papel que razões de autoridade devem desempenhar na justificação jurídica, uma vez que se pode maximizar a coerência de um sistema que compreende o Direito posto e moralidade política de uma forma

\footnotetext{
${ }^{119}$ Conforme Soriano: “... to justify is the activity of supporting a particular statement with good reasons. Legal justification involves two kinds of reasons: authority reasons - legal norms, precedents, and legal doctrine - and substantive reasons - values and principles". SORIANO, Leonor Moral. A Modest Notion of Coherence in Legal Reasoning. A Model for the European Court of Justice. Ratio Juris, v. 16, n. 3, p. 296-323, sep. 2003, p. 308.

${ }^{120}$ SORIANO, Leonor Moral. A Modest Notion of Coherence in Legal Reasoning. A Model for the European Court of Justice. Ratio Juris, v. 16, n. 3, p. 296-323, sep. 2003, p. 320.

${ }^{121}$ AMAYA NAVARRO, Amalia. An inquiry into the nature of coherence and its role in legal argument. $\mathrm{PhD}$ Theses. Department of Law. European University Institute, 2006.
} 
que se afasta significantemente do que o conjunto de padrões autoritativos requer. Amaya ${ }^{122}$ aponta como uma forma de se resolver esse problema, a atribuição às razões jurídicas de um peso inicial maior que ao resto de razões no cálculo de coerência, o que poderia gerar o paradoxo de as teorias coerentistas remeterem ao fundacionalismo ${ }^{123}$ ao qual se contrapõem.

Apesar desse e de todos os outros problemas que a teoria coerentista tem de enfrentar, tratados por Amalia Amaya ${ }^{124}$, e embora a maioria dos autores adote um modelo de coerência fraca, o modelo coerentista não deixa de dar valiosas contribuições à justificação das decisões judiciais em busca da racionalidade do processo decisório.

Em geral, há o entendimento compartilhado de que a coerência não se deve reduzir à consistência. Esta se trata de um critério de caráter lógico, envolvendo apenas ausência de contradições. A coerência, ao contrário, tem um significado muito mais amplo, sendo sinônimo de 'ajuste', 'consonância'. Nesse sentido, a coerência relaciona a decisão a um sistema que já está estruturado e teoricamente reconstruído, à luz de princípios unificadores e valores que tornem aquela parte do sistema jurídico, se não possível o sistema inteiro, um todo dotado de significação ${ }^{125}$.

Fazendo coro às abordagens coerentistas voltadas para o papel da coerência na justificação de conclusões sobre questões discutidas de Direito, sem explicitação sobre a coerência das conclusões sobre questões de fato discutidas - esta, segundo Amalia Amaya ${ }^{126}$, negligenciada pela literatura coerentista - serão expostas na sequência algumas propostas da teoria coerentista no Direito: a de MacCormick, de Peczenik, de Dworkin e de Susan Hurley; além do modelo inferencial, utilizado por Juliano Maranhão, como forma de justificar a autoridade dos princípios jurídicos com base nas regras postas, daí o resgate da vinculação à lei que parece se perder em outras propostas coerentistas.

\footnotetext{
${ }^{122}$ AMAYA NAVARRO, Amalia. An inquiry into the nature of coherence and its role in legal argument. $\mathrm{PhD}$ Theses. Department of Law. European University Institute, 2006.

${ }^{123} \mathrm{O}$ fundacionalismo tem por base o entendimento da existência de crenças justificadas por si. A proposta como a de Kelsen de uma norma fundamental como pressuposto epistemológico para a validade do sistema jurídico enquadra-se em uma perspectiva fundacionalista. Segundo Hage, na epistemologia focada no mundo físico, as teorias internalistas - segundo as quais a justificabilidade de uma crença é função do estado interno de quem crê - se dividiriam em duas espécies: as teorias fundacionalistas, que atribuem a certas aceitações um status privilegiado, de maneira que não demandam justificação; e as teorias coerentistas, que não atribuem status privilegiado a aceitações e a justificação das aceitações se baseia em coerência com outras aceitações. Essas duas espécies são exaustivas das teorias internalistas e mutuamente excludentes. HAGE, Jaap. Studies in Legal Logic. Dordrecht: Springer, 2005.

${ }^{124}$ Remete-se para tanto à tese da autora: AMAYA NAVARRO, Amalia. An inquiry into the nature of coherence and its role in legal argument. PhD Theses. Department of Law. European University Institute, 2006.

${ }^{125}$ VILLA, Vittorio. Normative Coherence and Epistemological Pressupositions of Justification. In: NERHOT, Patrick (Ed.). Law, Interpretation and Reality. Essays in Epistemology, Hermeneutics and Jurisprudence. Dordrecht: Kluwer Academic Publishers, 1990, p. 431-455.

${ }^{126}$ AMAYA NAVARRO, Amalia. An inquiry into the nature of coherence and its role in legal argument. $\mathrm{PhD}$ Theses. Department of Law. European University Institute, 2006.
} 


\subsection{TEORIAS COERENTISTAS NO DIREITO}

\subsubsection{Teoria coerentista de Neil MacCormick}

Neil MacCormick é um dos principais expoentes clássicos da teoria coerentista do Direito, tal como Aleksander Peczenik e Ronald Dworkin. Para se falar sobre sua teoria coerentista, insta apresentar-se o que MacCormick entende como coerência e qual a importância que atribui à coerência no raciocínio jurídico, de modo geral, e no judicial em particular.

A proposta coerentista de MacCormick toma como premissa a ideia de que o raciocínio jurídico é um ramo do raciocínio prático, o qual postula a aplicação pelos seres humanos da sua razão para decidir a forma correta de agir em situações de escolha - o que ocorre, no âmbito jurídico, sobretudo em casos de conflitos de princípios. Segundo MacCormick, há presunção de que as pessoas sejam racionais, no sentido de que tenham motivação para suas ações, com as quais buscam atingir certos objetivos, não agindo de maneira irracional e aleatória.

Uma das manifestações de racionalidade seria a adesão a princípios gerais, em contraste com reações meramente impulsivas às circunstâncias. Daí porque, no Direito, buscar esses princípios que dão embasamento ao sistema jurídico, tendo-se em vista determinados valores, seria um mecanismo de busca de racionalidade.

MacCormick não nega que, em muitos casos, basta a aplicação subsuntiva do Direito para se chegar a uma solução. No entanto, em diversos outros, revelam-se problemas que ele considera endêmicos ao Direito, quais sejam: problemas de interpretação, de relevância, de classificação e de prova, em que, embora o método da subsunção seja necessário, não é suficiente, pois é aplicável apenas após a solução desses problemas que são ocasionados, na visão de MacCormick, como legatário das teses de Hart $^{127}$, porque as regras são formuladas

\footnotetext{
${ }^{127}$ Embora MacCormick saliente com clareza a revisão de algumas adesões, quase absolutas anteriores, às teses de Hart. A primeira edição do Legal Reasoning and Legal Theory em 19878 era tributária das teses de Hart: "The account it gives of legal reasoning is represented as being essentially Hartian, grounded in or at least fully compatible with Hart's legal-positivistic analysis of the concept of Law". No entanto, ante as críticas à versão de 1978, MacCormick teve um afastamento de alguns pontos da tese anterior: "Carrying on the debate about legal reasoning and related issues has carried me well beyond the already muted version of legal positivism to which I subscribed in 1978. In fair measure, it has been response to criticisms of Legal Reasoning and Legal Theory that has held me to my present stance in what might be called a post-positivist institutional theory of law". MACCORMICK, Neil. Legal Reasoning and Legal Theory. New York: Oxford University Press, 2003, p. xiv$\mathrm{xv}$.
} 
na linguagem e, portanto, são dotadas de vagueza e portadoras de textura aberta em certos $\operatorname{contextos}^{128}$.

O problema de interpretação deve-se à possibilidade de diferenças de sentido atribuíveis às normas, o que gera a dificuldade de se definir qual o sentido a se aplicar no caso. O problema de relevância atine à dúvida sobre a efetiva tutela jurídica de certo caso. Já o problema de classificação decorre da dúvida se os fatos do caso correspondem aos fatos operativos da norma, enquanto os problemas de prova dizem respeito à obscuridade sobre os próprios fatos: não se sabe quais são os fatos realmente ocorridos.

Esses problemas entram na caracterização de MacCormick de casos difíceis, em contraposição aos casos $\operatorname{claros}^{129}$ em que a justificação de decisões pode ser alcançada pela simples dedução a partir de regras claras estabelecidas. Em verdade, sua definição de caso claro é praticamente circular: por ser claro aplica-se pelo método subsuntivo e é claro porque basta a subsunção para solucioná-lo.

Estão entre os casos claros aqueles em que não há nenhuma dúvida quanto à interpretação da regra ou a classificação dos fatos; ou ninguém cogitou de levantar ou argumentar uma questão que fosse arguível; ou ainda, em que o argumento foi testado, mas desconsiderado como artificial ou extremamente improvável ${ }^{130}$.

Não obstante, MacCormick reforça que não há uma delimitação clara entre casos claros e difíceis. Embora o que torne um caso claro seja a crença de que fatos provados sejam exemplos inequívocos de uma regra estabelecida, a clareza da regra é intrinsecamente discutível - e isso é próprio da discutibilidade do próprio Direito ${ }^{131}$-, já que problemas de interpretação ou classificação podem ser levantados ou podem surgir argumentos de princípio e consequencialistas que afastem certa regra. De modo que, o caso é claro até que não seja levantado nenhum questionamento.

Quando os problemas surgem e a dúvida sobre como se decidir - ou seja, em termos de razão prática -, os casos passam a ser difíceis, compreendidos como aqueles em que alguma dificuldade de interpretar o Direito surgiu, e em que há fortes argumentos para cada

\footnotetext{
${ }^{128}$ MACCORMICK, Neil. Legal Reasoning and Legal Theory. New York: Oxford University Press, 2003, p. 6566.

${ }^{129}$ Segundo MacCormick, o termo 'claro' é preferível a 'fácil', uma vez que muitas áreas do direito são enormemente complexas e mesmo casos nos quais nenhum problema de direito é levantado podem ser deveras complexos nas concatenações de fato e direito neles envolvidos. MACCORMICK, Neil. Rethoric and the Rule of Law: a theory of legal reasoning. Oxford: Oxford University Press, 2005, p. 51.

${ }^{130}$ MACCORMICK, Neil. Legal Reasoning and Legal Theory. New York: Oxford University Press, 2003, passim.

${ }^{131}$ MACCORMICK, Neil. Rethoric and the Rule of Law: a theory of legal reasoning. Oxford: Oxford University Press, 2005.
} 
uma das compreensões conflitantes. Por exemplo, considerações de justiça ou semelhantes podem, às vezes, sugerir novas interpretações ou desenvolvimentos ousados de princípios em novas direções ${ }^{132}$.

E a solução desses casos demanda previamente - para posteriormente aplicar-se o método subsuntivo - o que MacCormick chama de justificação de segunda ordem para se justificarem as premissas do silogismo normativo ${ }^{133}$, com base nas quais finalmente justificase a decisão no caso particular. A justificação de segunda ordem abrange dois elementos: de um lado argumentos de coerência e consistência e, de outro, argumentos consequencialistas $^{134}$.

Em sua proposta, na justificação jurídica, há dois tipos de teste de coerência. O teste de coerência normativa, que se relaciona à justificação das regras jurídicas ou proposições normativas no contexto de um sistema jurídico concebido como uma ordem normativa. $\mathrm{E}$ ao teste de coerência narrativa, relacionado à justificação das descobertas de fato e à descrição das inferências razoáveis a partir da evidência ${ }^{135}$.

A coerência normativa é relevante na solução do problema do conflito de princípios e diz respeito ao fato de um conjunto de proposições fazerem sentido em sua totalidade. E fazer sentido não significa não conter inconsistências internas, o que evidencia a diferença patente entre coerência e consistência.

A consistência é satisfeita pela não contradição: um sistema jurídico é consistente se não há contradição entre suas normas. A consistência completa não é necessária nem suficiente para a coerência ${ }^{136}$ : pode haver um sistema consistente, mas sem coerência, tanto

\footnotetext{
${ }^{132}$ MACCORMICK, Neil. Rethoric and the Rule of Law: a theory of legal reasoning. Oxford: Oxford University Press, 2005, p. 50.

${ }^{133}$ AMAYA NAVARRO, Amalia. An inquiry into the nature of coherence and its role in legal argument. $\mathrm{PhD}$ Theses. Department of Law. European University Institute, 2006.

${ }^{134}$ Segundo José Alcebíades de Oliveira Júnior, a teoria de MacCormick aponta na justificação de casos difíceis como requisito de primeiro nível a universalidade - a exigência de justiça formal (treat like cases alike); e como requisitos de segundo nível, consistência e coerência. Finalmente, há requisitos centrados nas consequências da ação, o que abrange argumentos de utilidade, razoabilidade e proporcionalidade, entendidos como argumentos consequencialistas. OLIVEIRA JÚNIOR, José Alcebíades. Casos Difíceis no Pós-Positivismo. In: BOUCAULT, Carlos Eduardo de Abreu; RODRIGUEZ, José Rodrigo (Orgs.). Hermenêutica Plural. São Paulo: Martins Fontes, 2005, p. 203-228.

${ }^{135}$ MACCORMICK, Neil. Rethoric and the Rule of Law: a theory of legal reasoning. Oxford: Oxford University Press, 2005, p. 198.

${ }^{136}$ Note-se que a referência é à consistência completa, em uma perspectiva coerentista global, em que inconsistências pontuais no sistema não afetariam a coerência do sistema como um todo no sentido de embasamento em um valor comum. Consoante MacCormick: “... I assume that 'coherence' can usefully be distinguished from consistency... So I interpret consistency as being satisfied by non-contradiction. A set of propositions is mutually consistent if each can without contradiction be asserted in conjunction with every other and with their conjunction. By contrast, coherence, as I said, is the property of a set of propositions which, taken together, 'makes sense' in its entirety. Complete consistency is not a necessary condition of coherence, since unlike consistency, coherence can be a matter of degree. A story can be coherent on the whole and as a whole,
} 
quanto um sistema inconsistente, mas coerente. Isso porque a coerência de um sistema diz respeito ao fato de ele fazer sentido e isso só é possível se há um valor comum (ou valores comuns) orientadores da promulgação das regras.

A esse respeito, MacCormick utiliza o exemplo da legislação italiana em que se determinavam diferentes limites de velocidade consoante diferentes tipos e estilos de carros. Então, a cor do carro seria um fator relevante para se determinar o limite de velocidade para aquele veículo, já que para cada cor estava estipulado um específico limite de velocidade, o que demonstra que não havia inconsistências naquele sistema normativo (carro A com limite $\mathrm{x}$, carro B com limite z).

No entanto, se fossem consideradas como três fins para a limitação de velocidade a segurança dos usuários de rodovias, a economia de combustível e a prevenção de danos às rodovias, embora diferentes normas para diferentes carros fossem consistentes - visto que as regulamentações não eram conflitantes -, as normas não se justificariam tendo-se em vista os fins da tutela.

Assim, o que MacCormick pretende dizer com sua definição de coerência de um sistema de regras como a satisfação ou exemplificação de um princípio mais geral ou seu caráter de 'fazer sentido' é que o que dá coerência ao sistema normativo são os valores expressos por princípios - que ele busca tutelar e que embasam as normas ${ }^{137}$.

Isso porque, segundo MacCormick, há uma equivalência extensional entre 'valores' e 'princípios', já que para qualquer valor existe um princípio conforme o qual esse valor pode ser ou deveria normalmente ser, ou deve - na ausência de considerações superadoras - ser buscado ou realizado, já que tais princípios e/ou valores na sua totalidade expressam uma forma de vida satisfatória, na qual seria possível para os seres humanos, como seres humanos que são, viver.

Ou seja, os princípios são ao mesmo tempo expressões de valores e meios de racionalização das regras. Dessa forma, a coerência de um sistema de normas é uma função da

\footnotetext{
though it contains some internal inconsistencies - and in this case, the sense of the overall coherence of the story may be decisive for us in deciding which among pairs of inconsistent propositions to disregard as anomalies in an overall coherent account or opinion" [destaques nossos]. MACCORMICK, Neil. Rethoric and the Rule of Law: a theory of legal reasoning. Oxford: Oxford University Press, 2005, p. 190. Já Peczenik considerará a consistência como condição necessária, mas não suficiente de coerência, conforme seção seguinte (2.2.2). PECZENIK, Aleksander. Law, Morality, Coherence and Truth. Ratio Juris, v. 7, n. 2, p. 146-176, jul. 1994. ${ }^{137}$ MACCORMICK, Neil. Coherence in Legal Justification. In: PECZENIK, A. et al (eds.) Theory of Legal Science: Proceedings of the Conference on Legal Theory and Philosophy of Science. Dordrecht: Reidel Publishing Company, 1984, p. 235-251, p. 236.
} 
sua justificabilidade sob princípios ou valores de mais alta ordem, assim caracterizados por promoverem a referida 'forma de vida satisfatória' ${ }^{138}$.

Destarte, no argumento de coerência, a tarefa dos juízes é de dois níveis: primeiro o questionamento quanto aos princípios ou valores que, na medida do possível, fazem sentido como um sistema relevante de normas jurídicas ou princípios ou valores 'subjacentes', que podem ser concebidos como justificativos das regras sob consideração. Então, tais princípios ou valores são aplicados com o propósito de justificar a regra efetiva na situação do caso, como uma aplicação análoga dos mesmos princípios e valores e então como coerente com o corpo jurídico pré-estabelecido, mediante a presunção - ainda que contrafática - da intenção do legislador de legislar coerentemente.

Por essa razão, um sistema de regras seria coerente se todas elas satisfizessem ou fossem exemplos de um único princípio mais geral. Nota-se daí uma imbricação da coerência com a consistência com o direito posto. Ou seja, para uma decisão jurídica ser justificada, deve-se demonstrar sua consistência com as regras estabelecidas ${ }^{139}$. Daí porque MacCormick afirma que juízes devem fazer justiça, mas justiça conforme o Direito ${ }^{140}$.

A importância da coerência normativa na justificação e racionalidade da decisão judicial em tais casos, deve-se ao fato de que uma concepção de racionalidade na vida prática é satisfatória e a racionalidade requer tanto universalidade quanto máximo grau possível de generalidade em princípios práticos. Isso porque regras relativamente detalhadas serão arbitrárias se não forem também exemplos de princípios mais gerais. A coerência é o mecanismo de se buscar tais princípios e valores justificatórios da regra e de sua aplicação concreta.

No entanto, dessa forma, a coerência apenas garantiria justiça formal - ou seja, universalidade e generalidade, em atendimento à exigência de tratamento igual a casos semelhantes; bem como a não arbitrariedade que garante, porque os princípios mais gerais justificam as especificações das regras; a cognoscibilidade e previsibilidade, em razão da exigência de atenção ao direito posto - pois tais atributos não concernem ao conteúdo dos sistemas normativos e, por conseguinte, à coerência -, o recurso aos princípios - não satisfaz

\footnotetext{
${ }^{138}$ MACCORMICK, Neil. Coherence in Legal Justification. In: PECZENIK, A. et al (eds.) Theory of Legal Science: Proceedings of the Conference on Legal Theory and Philosophy of Science. Dordrecht: Reidel Publishing Company, 1984, p. 235-251, passim.

${ }^{139}$ AMAYA NAVARRO, Amalia. An inquiry into the nature of coherence and its role in legal argument. $\mathrm{PhD}$ Theses. Department of Law. European University Institute, 2006, p. 11.

${ }^{140}$ MACCORMICK, Neil. Legal Reasoning and Legal Theory. New York: Oxford University Press, 2003, passim.
} 
exigências de justiça substantiva, pois nada impede que um sistema jurídico coerente seja aberrante do ponto de vista moral ${ }^{141-142}$.

Dessa maneira, a coerência apenas provê justificação formal e relativista, o que MacCormick denomina de 'derivabilidade fraca', já que o raciocínio coerentista apenas provê uma restrição negativa de que o juiz só pode decidir de uma forma que seja ao menos fracamente derivável do direito existente, limitando a discrição judicial. Mas não provê defensabilidade da decisão judicial do ponto de vista moral, de modo que a justificação positiva de qualquer regra jurídica seria finalmente estabelecida por argumentos de consequência, que proveem justificação substancial ${ }^{143}$.

MacCormick ${ }^{144}$ reconhece a coerência como elemento que dá racionalidade ao Direito, até porque permite delimitar um rol de respostas aceitáveis, conforme o Direito, mas não sendo ultrarracionalista, reconhece limites à própria racionalidade, até mesmo porque considerando-a uma característica ideal do Direito, entende que a coerência pode competir com outras características ideais, como a justiça substantiva, e esta entra no julgamento de substância sobre qual a decisão genuinamente melhor entre as legalmente admissíveis ${ }^{145}$.

Por essa razão, Amalia Amaya ${ }^{146}$ afirma que argumentos de coerência são decisivos na determinação se uma decisão jurídica é ‘justificável', mas que, para demonstrar uma decisão jurídica como ‘justificada’ e não meramente justificável, a proposta de MacCormick leva aos

${ }^{141}$ Conforme Schiavello, MacCormick considera a coerência como um padrão formal no sentido de neutro, já que não diz respeito ao caráter bom ou ruim dos princípios aos quais a lei e o juiz devem se ajustar. SCHIAVELLO, Aldo. On "Coherence" and "Law": An Analysis of Different Models. Ratio Juris, v. 14, n. 2, p. 233-243, jun. 2001, p. 236.

${ }^{142}$ Isso leva à ponderação de que há "[...] uma zona perigosa. A justificação com base na coerência poderia chegar a ponto de, por exemplo, fundamentar um direito nazista, baseado na conexão com um princípio anterior de pureza racial. Por isso é que, como adverte MacCormick, 'a coerência enquanto um valor puramente interno do Direito, do Direito efetivo de uma dada jurisdição, não é, por si só, uma garantia suficiente de justiça"”. MARTINS, Argemiro Cardoso Moreira; ROESLER, Cláudia Rosane; JESUS, Ricardo Antonio Rezende de. A noção de coerência na teoria da argumentação jurídica de Neil MacCormick: caracterização, limitações, possibilidades. Revista Novos Estudos Jurídicos - Eletrônica, v. 16, n. 2, p. 207-221, mai.-ago. 2011, p. 217. Disponível em: <http://siaiweb06.univali.br/seer/index.php/nej/article/view/3281/2064>. Acesso em 18 jan. 2012 143 AMAYA NAVARRO, Amalia. An inquiry into the nature of coherence and its role in legal argument. $\mathrm{PhD}$ Theses. Department of Law. European University Institute, 2006, passim.

${ }^{144}$ MACCORMICK, Neil. Rethoric and the Rule of Law: a theory of legal reasoning. Oxford: Oxford University Press, 2005, p. 203.

${ }^{145}$ Segundo Flávia Carbonnel, admissivelmente há limites para o uso de coerência na argumentação jurídica, de que MacCormick está a par. Contudo, um argumento incompleto ou insuficiente continua a ser um critério de justificação, e esses limites apenas significariam que outros argumentos, tais como teleológicos ou deontológicos - argumentos de consequência e princípio - serão necessários para justificar as decisões. O que é importante para uma argumentação sensata, para a autora, seria explicitamente fazer conexões e apontar as razões subjacentes à decisão e demonstrar por que a solução dada é melhor ou preferível para o caso em questão. CARBONELL, Flavia. Coherence and Pos-sovereign Legal Argumentation. In: MENÉNDEZ, Agustín José; FOSSUM, John Erik (Eds.). Law and Democracy in Neil MacCormick's Legal and Political Theory. The PostSovereign Constallation, p. 157-182, p. 180.

146 AMAYA NAVARRO, Amalia. An inquiry into the nature of coherence and its role in legal argument. $\mathrm{PhD}$ Theses. Department of Law. European University Institute, 2006. 
argumentos consequencialistas, que precisam ser empregados para se escolher como justificada uma decisão entre um rol de decisões alternativas que satisfazem o teste de coerência.

Assim, a valoração é necessária para determinar como melhor alcançar o ideal de justiça substantiva no curso da elaboração da decisão judicial, de modo que em todos os casos nos quais a coerência com o Direito posto não implica uma única decisão, a razão cessaria, e tomaria lugar a decisão com base em preferências pessoais, pois a justiça substancial seria alcançada por argumentos consequencialistas e, na medida em que questionamentos sobre a aceitabilidade ou inaceitabilidade das consequências das regras são intrinsecamente valorativos e parcialmente subjetivos, pois ao valorarem as consequências de regras contrárias aplicáveis, juízes poderiam dar diferente peso a diferentes critérios de avaliação ${ }^{147}$.

Embora a teoria coerentista de MacCormick seja fraca, uma vez que a coerência é elemento necessário, mas não suficiente para a justificação das decisões judiciais, isso não afasta a importância da coerência na racionalidade do processo decisório e na garantia de justiça formal e, como aponta Amalia Amaya ${ }^{148}$, a teoria de MacCormick, embora limitada, porque em última análise a decisão do juiz não está estritamente vinculada à lei, reconhece, de uma forma que o positivista formal não fizera, a relevância da coerência na justificação jurídica, e amplia o espaço da razão no Direito, embora de modo bastante modesto, para além dos limites do argumento dedutivo.

\subsubsection{Teoria coerentista de Aleksander Peczenik}

Tal como em Neil MacCormick, a coerência é para Aleksander Peczenik um mecanismo de justificação das decisões judiciais. Ao tratar sobre o conceito de coerência em artigo conjunto com Robert Alexy, os autores reconhecem a dificuldade de se abordar esse conceito, dada sua vagueza e discutibilidade, sendo possível concebê-lo de diversas formas. No artigo referido, os autores buscam formular o conceito, apresentando-o sinteticamente como: Quanto mais proposições pertencentes a uma dada teoria se aproximam de uma estrutura de sustentação perfeita, mais coerente a teoria ${ }^{149}$.

\footnotetext{
${ }^{147}$ Isso se coaduna com a adesão do segundo MacCormick ao que ele considera como pós-positivismo: não um anti-positivismo, mas a assunção de pautas morais.

${ }_{148}$ AMAYA NAVARRO, Amalia. An inquiry into the nature of coherence and its role in legal argument. $\mathrm{PhD}$ Theses. Department of Law. European University Institute, 2006, p. 18.

149 ALEXY, Robert; PECZENIK, Aleksander. The Concept of Coherence and Its Significance for Discursive Rationality. Ratio Juris, v. 3, n. 1, p. 130-147, mar. 1990, p. 131.
} 
A partir dessa ideia principal, os autores fazem a análise do conceito. O termo 'teoria' é empregado em sentido amplo, abarcando tanto teorias descritivas (como as empíricas), quanto as normativas ou valorativas. Sustentação é entendida em sentido fraco na acepção de que uma proposição $p_{1}$ sustenta uma proposição $p_{2}$ se, e apenas se, $p_{1}$ pertence a um sistema de premissas $\mathrm{S}$, a partir do qual $p_{2}$ segue-se logicamente ${ }^{150}$.

A estrutura de sustentação dependerá das relações de sustentação entre as proposições da teoria, e o grau de perfeição da estrutura de sustentação depende do grau no qual os critérios de coerência são preenchidos, ou seja, quanto maior o grau de preenchimento dos critérios de coerência, mais perfeita a estrutura de sustentação.

Peczenik e Alexy entendem que esses critérios de sustentação tornam o conceito de coerência mais preciso e que, como estão relacionados, o grau de coerência depende do sopesamento desses critérios ${ }^{151}$ e o grau de perfeição da sustentação depende do grau no qual os critérios são preenchidos - daí a necessidade de sopesá-los.

No total, contam-se dez critérios de coerência que são divididos em três classes ${ }^{152}: 1$ ) As propriedades da estrutura de sustentação constituídas pela teoria (critérios 1-6); 2) As propriedades dos conceitos aplicados por ela (critérios 7-8); 3) As propriedades do âmbito abarcado pela teoria (critérios 9-10). Cada uma das classes admite também subdivisões correlacionadas (critérios 1-10). Pode-se esquematicamente sintetizar a classificação da seguinte forma:

\footnotetext{
${ }^{150}$ Note-se, contudo, que há para Peczenik clara distinção entre coerência e consistência. Esta é condição necessária, mas não suficiente de coerência. Segundo Peczenik, "Incoherence would consist in the fact that though the decisions are logically compatible, their relation to each other is arbitrary". O que denota que, para a coerência, não basta a ausência de inconsistências. ALEXY, Robert; PECZENIK, Aleksander. The Concept of Coherence and Its Significance for Discursive Rationality. Ratio Juris, v. 3, n. 1, p. 130-147, mar. 1990, p. 137.

151 "The degree of perfection of support depends on the degree to which the criteria of coherence are fulfilled. Criteria of coherence make the concept of coherence more precise". PECZENIK, Aleksander. Law, Morality, Coherence and Truth. Ratio Juris, v. 7, n. 2, p. 146-176, jul. 1994, p. 168.

${ }^{152}$ A explanação dos critérios também é reproduzida por Peczenik em trabalho individual. Vide: PECZENIK, Aleksander. On Law and Reason. Lund: Springer, 2008.
} 


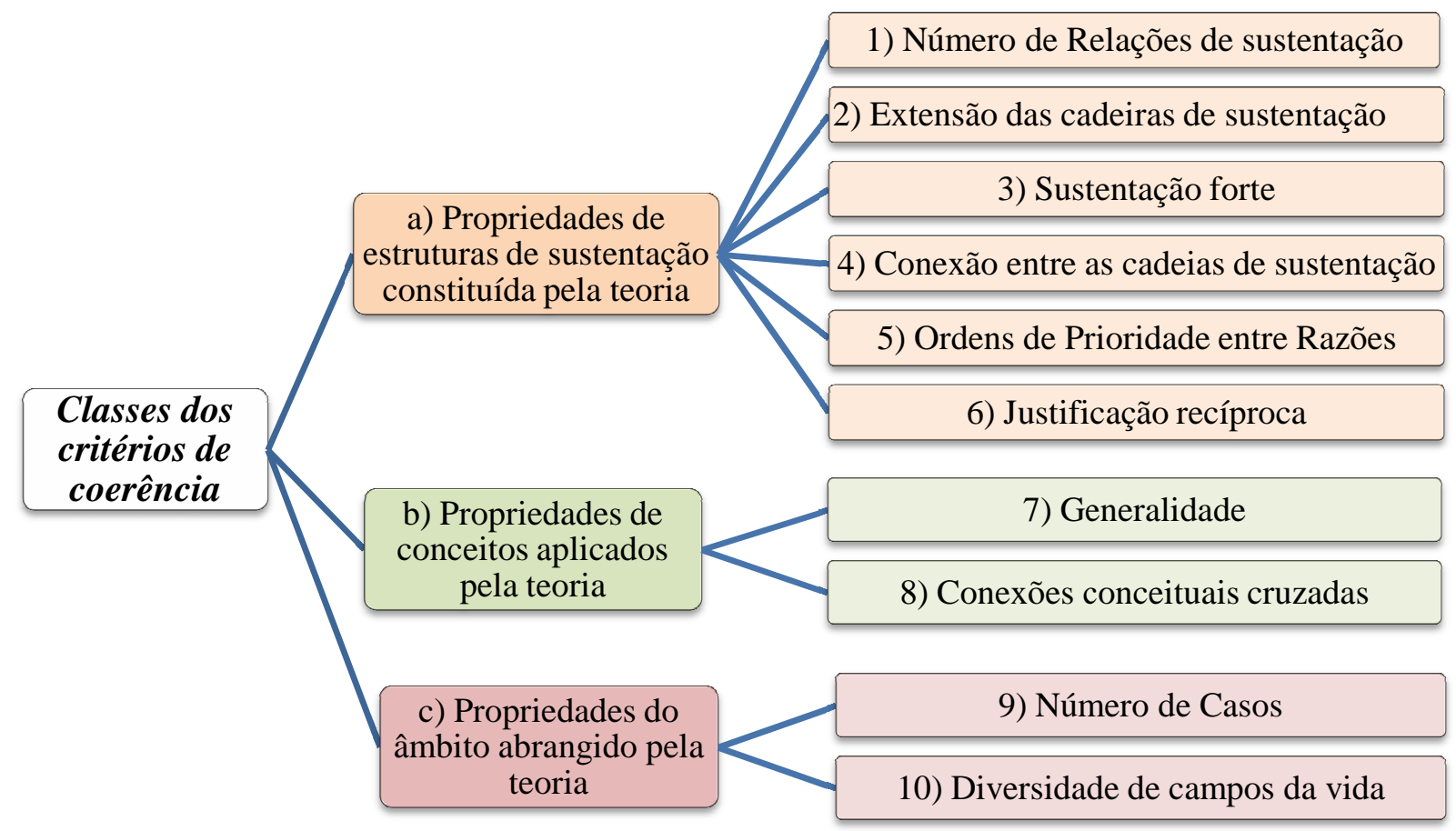

Na especificação dos critérios, Peczenik e Alexy usam as expressões "ceteris paribus" e "tanto... quanto possível" para indicar a mesma coisa e no sentido de que nenhum princípio ou critério de coerência é suficiente, mas deve ser sopesado com outros. Por isso, nas apreciações de cada um, usarão tais cláusulas, visto que, no fim, devem ser ponderados os diferentes critérios que, eventualmente, podem levar a resultados opostos.

Quanto ao número de relações de sustentação, a condição mínima de coerência é de que uma teoria coerente contenha proposições sustentadas por razões. Assim, ceteris paribus, quanto mais proposições pertencentes a uma teoria são sustentadas, mais coerente a teoria e, portanto, deve-se justificar tantas proposições quanto possível.

Segundo o critério da extensão das cadeias de sustentação, a coerência depende da extensão das cadeias de sustentação pertences à estrutura de sustentação: cadeias maiores ( $p_{1}$ sustenta $p_{2}, p_{2}$ sustenta $p_{3}$, etc.) tornam a estrutura de sustentação mais complexa e, por conseguinte, a teoria mais estruturada. Assim, ceteris paribus, quanto maior o número de cadeias de razões pertencentes à teoria, mais coerente ela será e, pois, quando se justifica uma proposição, dever-se-ia sustentá-la com uma cadeia de razões tão extensa quanto possível.

O terceiro critério, sustentação forte, diz respeito ao fato de que uma premissa pode ocupar uma proposição peculiar: no raciocínio jurídico, a decisão deveria estar sustentada por razões jurídicas. Então, as fontes do Direito, a previsão legal, frequentemente têm uma 
posição especial $^{153}$. E se uma previsão legal possui tal posição, fortemente sustenta uma decisão.

Esse tipo de sustentação forte ocorre quando cada parte do sistema de premissas $\mathrm{S}$ pertence a um subsistema com as seguintes propriedades: a decisão se segue logicamente dele; as partes do subsistema são necessárias para inferir a decisão a partir desse subsistema; e a decisão não se segue de qualquer subsistema de $S$ ao qual a decisão não pertença.

Assim, a proposição $p_{1}$ sustenta fortemente a $p_{2}$ se, e apenas se, $p_{1}$ pertence a um sistema de premissas $\mathrm{S}$ com as seguintes propriedades: a) nenhuma das premissas é insignificante ou falsificada; b) pelo menos um subsistema de $\mathrm{S}$ é tal que: $p_{2}$ se siga logicamente dele e todos os membros do subsistema são necessários para inferir $p_{2}$ a partir desse subsistema, pois ele não se segue se qualquer premissa for retirada do subsistema; c) cada membro do sistema $\mathrm{S}$ pertença a, pelo menos, um subsistema e; d) $p_{1}$ é também necessário no sentido forte de que $p_{2}$ não se segue de qualquer premissa de $S$ ao qual $p_{1}$ não pertença.

Assim, quanto mais proposições pertencentes a uma teoria são fortemente sustentadas por outras proposições, mais coerente a teoria. E a importância de se demonstrarem os níveis intermediários ( $p_{1}$ sustenta $p_{2}, p_{2}$ sustenta $p_{3}, p_{3}$ sustenta $p_{4} \ldots$; em vez de $p_{1}$ sustenta $p_{4}$ ) é que ao se expor a estrutura de sustentação, com todos os seus níveis (inclusive os intermediários $\left.p_{2}, p_{3}\right)$ fortalece-se a cadeia de sustentação e, portanto, a teoria.

O quarto princípio ou critério é a conexão entre as cadeias de sustentação, da qual depende a coerência. Há dois tipos de conexões: primeiro a mesma premissa pode sustentar diferentes conclusões (a exemplo de princípios que sustentam diversas regras jurídicas, tornando-as coerentes); segundo, a mesma conclusão pode-se seguir de diferentes premissas. Assim, ceteris paribus, quanto maior o número de conclusões sustentadas pela mesma premissa pertencente à teoria, mais coerente a teoria.

E quanto à segunda conexão, ocorre em muitos casos que a conclusão seja sustentada por muitas razões insuficientes por si mesmas, mas que proveem conjuntamente boa evidência. Ou a mesma conclusão pode se seguir de diversas razões independentes, cada uma suficiente. Esse critério pode ser expresso como: ceteris paribus, quanto maior o número de sistemas de premissas independentes em uma teoria, de modo que a conclusão se siga de cada um dos subsistemas, mais coerente a teoria.

\footnotetext{
${ }^{153}$ Como alegam os autores: "Lawyers often argue that a decision should be supported by a statute. The same statute may support many decisions. To be sure, many other premises are also included in the supportive structure...”. Aqui já apontam, pois, matizações. ALEXY, Robert; PECZENIK, Aleksander. The Concept of Coherence and Its Significance for Discursive Rationality. Ratio Juris, v. 3, n. 1, p. 130-147, mar. 1990, p. 133.
} 
O quinto critério diz respeito à ordem de prioridade entre as razões, já que diferentes cadeias de razões podem sustentar conclusões incompatíveis por diversas causas, como a existência de regras logicamente incompatíveis ou colisão de princípios. E a única forma de se solucionar a questão seria estabelecer relações de prioridade definitivas e relações de prioridade prima facie, para se evitar o risco de que o sistema fosse usado para justificar decisões incoerentes (no sentido de que, embora as decisões fossem logicamente compatíveis, sua inter-relação seria arbitrária).

Esse critério é expresso da seguinte forma: (a) se a teoria em questão contém princípios, então, ceteris paribus, quanto maior o número de ordens de prioridade entre os princípios, mais coerente a teoria ou, por outras palavras, (a') quando se usam princípios pertences a uma teoria como premissas que justificam uma proposição, devem-se formular tantas ordens de prioridade entre os princípios quanto possível.

O sexto critério de justificação recíproca é o de um sistema em que as proposições sustentem-se mutuamente, o que significaria que $p_{2}$ se segue de $p_{1}$ e este se segue de $p_{2}$, o que implica equivalência entre as proposições e, sendo o sistema tautológico, teria efetivamente uma única proposição e isso fulminaria o critério das cadeiras de sustentação.

Por essa razão, Alexy e Peczenik defendem ser necessária outra definição de sustentação segundo o qual $p_{1}$ possa sustentar $p_{2}$, mesmo que $p_{2}$ não se siga apenas de $p_{1}$. $\mathrm{Ou}$ seja, $p_{1}$ sustentará $p_{2}$ apenas se pertencer a um sistema de premissas $\mathrm{S}$ do qual $p_{2}$ se siga logicamente e vice-versa. Então, $p_{1}$ junto com outras proposições sustenta $p_{2}$ e o contrário também. Essa sustentação mútua pode ser de três tipos: empírica, analítica e normativa ${ }^{154}$. Sendo que, ceteris paribus, quanto maior o número de relações empíricas, analíticas e normativas entre as proposições pertences a uma teoria, mais coerente a teoria.

Já quanto às propriedades dos conceitos empregados pela teoria, podem-se divisar dois critérios: (7) generalidade e (8) conexões conceituais cruzadas. A generalidade é critério usado em sentido amplo, podendo se referir a: universalidade, generalidade em sentido estrito e semelhanças. A universalidade atine ao uso de conceitos a todas as coisas pertencentes a uma classe, sendo que a universalidade como uso de conceitos, é uma condição necessária de toda a coerência.

\footnotetext{
154 A sustentação empírica pode ser exemplificada pela aplicação institucional de direitos básicos como condição do procedimento democrático e este como condição fática para aquela, por exemplo; a sustentação analítica, a exemplo da validade de direitos básicos como condição necessária para um Estado de Direito integralmente desenvolvido e este como pressuposto de validade de direitos básicos. Por fim, a sustentação normativa atine à mútua sustentação entre proposições gerais e especiais. Tal como exemplificado entre partes geral e especial de Códigos.
} 
A generalidade, por sua vez, pode ser graduada, como no caso de partes gerais de Códigos, mais gerais em relação a suas partes especiais. Já a semelhança existe quando o conceito em questão se refere a uma variedade de fenômenos similares, o que se percebe na justificação jurídica pelo uso de analogia: tanto pela ampliação do significado linguístico de leis para abarcar novos casos ou para estender a aplicação de uma norma jurídica para além de seus limites estritamente linguísticos.

Podendo-se exprimir esse critério e suas subdivisões da seguinte forma: 7.1. Ceteris paribus, quanto mais proposições sem nomes individuais uma teoria use, mais coerente a teoria; 7.2. Ceteris paribus, quanto maior o número de conceitos gerais pertencentes a uma teoria, e quanto maior o seu grau de generalidade, mais coerente a teoria; 7.3. Ceteris paribus, quanto mais semelhanças entre conceitos usados em uma teoria, mais coerente a teoria.

Quanto ao oitavo critério, pode-se expressá-lo como: 8. Ceteris paribus, duas teorias são coerentes na medida em que usam os conceitos, estruturas e regras, dentre outros, análogos. Assim, 8.1 - Ceteris paribus, quanto mais conceitos uma dada teoria $\mathrm{T}_{1}$ tem em comum com outra $\mathrm{T}_{2}$, mais coerentes são essas teorias entre si; e, 8.2 - Ceteris paribus, quanto mais conceitos uma teoria $\mathrm{T}_{1}$ contenha que se assemelhe a conceitos usados em outra teoria $\mathrm{T}_{2}$, mais coerentes são essas teorias entre si. O que demonstra que se diz aqui tanto sobre conceitos comuns (8.1), quanto semelhantes (8.2).

Quanto às propriedades do âmbito abrangido pela teoria, tem-se o número de casos (9) e a diversidade de campos da vida (10). Segundo o critério 9: Ceteris paribus, quanto maior o número de casos individuais uma teoria abarca, mais coerente a teoria. E como em alguma medida o número de casos que uma teoria abrange depende das dimensões da estrutura de sustentação e da generalidade dos conceitos aplicados, o critério 9 está diretamente relacionado aos critérios 1 a 8 .

No referente ao critério 10, uma teoria terá maior amplitude se os casos aos quais ela se aplica são mais diversificados, isto é, se pertencerem a áreas mais diferentes do conhecimento, podendo-se enunciar como critério 10: Ceteris paribus, quanto mais campos da vida uma teoria cobre, mais coerente a teoria.

Finalmente, contudo, após se avaliarem os critérios elencados, o grau de coerência da teoria ou decisão definitiva deve-se ainda à ponderação e sopesamento dos diferentes critérios indicados, não se podendo seguir tais critérios isoladamente (daí a justificação do emprego da cláusula ceteris paribus ao se referir didaticamente a cada critério separadamente) e, em caso de serem antitéticos, deve-se buscar um ato complexo de ponderação para se responder à 
questão de qual teoria é a mais coerente, a mais geral e que contém a mais extensa cadeia de $\operatorname{razões}^{155}$.

Não obstante, os autores não se referem a como os diferentes critérios possam ser reciprocamente ponderados na tomada de decisão e, com isso, segundo aponta Amalia Amaya $^{156}$, embora os autores tenham contribuído de forma importante para a teoria coerentista ao listarem critérios claros com os quais a coerência de um sistema normativo de proposições particular pode ser testado, o silêncio sobre como fazê-lo acaba resultando em uma teoria, em um sentido importante, incompleta.

Com isso, apesar dos grandes benefícios desse modelo coerentista - no sentido de que o preenchimento dos critérios de coerência dá a percepção de sistema e a sistematização facilita o trabalho do julgador, porque as decisões não são tomadas ad hoc e isso também tem a vantagem de promover a justiça, ao menos no sentido formal - não se poderia descurar de suas limitações: o fato de a coerência não garantir uma resposta única, mas admitir matizações, visto que a coerência é questão de grau e que a ponderação de razões não leva a resultados certos; ainda, dado seu caráter formal, a coerência não impede conteúdos injustos e irrazoáveis; e, finalmente, há o problema intransponível da incompletude dos sistemas normativos (em razão da vagueza e ambiguidade da própria linguagem), a despeito do grau de sua coerência ${ }^{157}$.

Também é de se salientar que a coerência não é o único elemento que entra na justificação das decisões judiciais, o que revela ser a teoria coerentista de Peczenik fraca, visto que a coerência é por ele considerada como necessária, mas não suficiente. Em verdade, na justificação forte entram em jogo tanto a criação de um sistema de proposições tão coerente quanto possível, com base, finalmente, na ponderação dos critérios de coerência mencionados; quanto, um procedimento de argumentação tão racional quanto possível, que abarca não apenas razões jurídicas ${ }^{158}$.

\footnotetext{
${ }^{155}$ ALEXY, Robert; PECZENIK, Aleksander. The Concept of Coherence and Its Significance for Discursive Rationality. Ratio Juris, v. 3, n. 1, p. 130-147, mar. 1990, p. 143.

${ }^{156}$ AMAYA NAVARRO, Amalia. An inquiry into the nature of coherence and its role in legal argument. $\mathrm{PhD}$ Theses. Department of Law. European University Institute, 2006, p. 24.

${ }^{157}$ ALEXY, Robert; PECZENIK, Aleksander. The Concept of Coherence and Its Significance for Discursive Rationality. Ratio Juris, v. 3, n. 1, p. 130-147, mar. 1990, passim.

${ }^{158}$ No entanto, consoante Amalia Amaya pode-se notar uma revisão da teoria de Peczenik: em sua proposta conjunta com Alexy a teoria coerentista tinha caráter fraco, a coerência era um dos elementos da justificação, junto com a argumentação racional; já em um segundo momento Peczenik adere a uma proposta coerentista forte, a argumentação racional passa a ser a própria coerência e esta é condição necessária e suficiente de justificação jurídica. AMAYA NAVARRO, Amalia. An inquiry into the nature of coherence and its role in legal argument. PhD Theses. Department of Law. European University Institute, 2006, p. 37.
} 
Aqui importa explicitar algumas diferenciações traçadas por Peczenik entre regras e princípios; casos fáceis e difíceis; razões contributivas e decisivas e razões prima facie e definitivas. Todas essas diferenciações estão, contudo, intimamente correlacionadas. Peczenik parte da diferenciação entre regras e princípios no sentido traçado por Alexy. Assim, uma regra deve ser aplicada na forma tudo-ou-nada e o princípio, segundo o mandado de otimização, aplicado na maior medida possível como resultado de ponderação. Se há uma regra que comine uma consequência jurídica a determinados fatos operativos e, na prática, são constatados esses fatos, a regra é aplicável e, portanto, ela determinará a solução do caso.

Isso é válido para casos fáceis ou rotineiros, nos quais, segundo Peczenik, a solução está predeterminada pela regra. Nesses casos, as regras são consideradas como certas e simplesmente são aplicadas. Já nos casos difíceis, há a possibilidade de se desviar da letra da lei e a decisão não se dá de forma meramente dedutiva: é preciso uma premissa adicional, normativa ou valorativa ${ }^{159}$.

Embora as regras sejam consideradas como razões decisivas nos casos claros, ou seja, elas determinam uma solução que deve ser aplicada, sem a necessidade de mais ponderação. Isso não ocorre em casos difíceis, nos quais tanto quanto os princípios, as regras não mais determinam a solução a se adotar.

Em outras palavras, em casos claros, se uma regra é aplicável ao caso, ela afastará quaisquer razões, mesmo princípios, contrárias à sua aplicação e será aplicada. Mas há casos em que é possível que um princípio gere exceção à regra e ele prevaleça, afastando a aplicação desta. Então, casos em que uma regra é aplicável não serão resolvidos com base em ponderação de princípios, isso porque se considera que o legislador já ponderou razões eventualmente conflitantes, determinando a solução a se adotar.

No entanto, mesmo regras que não apresentem ambiguidade, podem, em alguns casos, embora não sempre, ainda ser ponderadas com considerações de moralidade e eficiência, em situações, por exemplo, em que se considere que o Direito, sem o mínimo de moralidade, deixa de ser Direito.

Dessa forma Peczenik rompe com o paradigma da defensabilidade apenas de princípios já que também reconhece a defensabilidade de regras. Como regra (e o trocadilho se faz necessário), regras devem ser aplicadas, mas pode haver exceções, seja pela inconsistência de regras, de modo que sejam razões decisivas para soluções contrapostas, caso em que apenas uma delas deverá prevalecer, seja porque princípios jurídicos ou razões morais

${ }^{159}$ PECZENIK, Aleksander. Law, Morality, Coherence and Truth. Ratio Juris, v. 7, n. 2, p. 146-176, jul. 1994, 147. 
venham a impelir a seu afastamento como resultado de um procedimento de ponderação de razões $^{160}$.

Do que se pode levantar o questionamento sobre qual a real diferença entre regras e princípios na teoria de Peczenik. A diferença remanesce, mas com matização. Em sua reformulação, embora as regras sejam reconhecidas como tão defensáveis quanto princípios, isso não ocorre em todos os casos. De modo que as regras podem ser defensáveis, enquanto os princípios sempre o são. Em casos considerados fáceis, as regras são tomadas como certas e aplicadas, sem necessidade de avaliação da coerência e de ponderação. Já nos casos difíceis, elas serão defensáveis - em relação a outras razões jurídicas e morais - e exigirão ponderação.

Dessa maneira, em casos considerados difíceis, tanto regras quanto princípios são razões prima facie, ou seja, a priori, visto que não determinam o resultado da decisão, o qual será inferido a partir de ponderação das razões conflitantes, levando à solução definitiva (allthings-considered). Não se pode, contudo, confundir-se razão prima facie com razão contributiva. Esta é uma razão efetiva, e não a priori, e caracteriza os princípios, que nunca são determinantes, mas apenas orientadores (contributivos) de certos resultados, visto que os princípios não determinam por si sós soluções, mas devem entrar em um sistema de todas as razões pró e contra que determinam a conclusão após ponderação. Já as regras são razões decisivas e, em geral, são sempre aplicadas sem ponderação, embora potencialmente afastáveis em casos difíceis.

Nesses casos, entram no cálculo de sopesamento, por um lado, razões jurídicas e, por outro, razões morais. No que diz respeito às razões jurídicas, gozam de status superior, até mesmo porque, para se caracterizar uma decisão como jurídica, não se pode prescindir do Direito posto. E aqui se pode questionar se esta não seria uma perspectiva fundacionalista.

Para não cair nessa abordagem antitética à proposta coerentista, o que minaria a teoria de Peczenik, este lança como solução para a justificação coerentista seu caráter circular. A circularidade deve-se ao fato de que uma razão sustenta a outra e, finalmente, a última deverá sustentar a primeira se não se desejar cair em bases fundacionalistas nem em infinito regresso,

\footnotetext{
${ }^{160}$ Isso pode ocorrer, a despeito da presunção de que o legislador levou em conta todos os casos relevantes, pois se cogita de que alguns relevantes não tenham sido devidamente considerados e esses fatos relevantes podem influir no resultado, inclusive pelo afastamento da regra. Essa será então uma razão contributiva para não aplicar a regra que deve ser ponderada com razões para aplicá-la. Então, há casos em que princípios justificam o afastamento de regras, embora não haja diretiva: aqui o princípio afasta a regra e lá não ou vice-versa. As decisões serão sempre pontuais. HAGE, Jaap; PECZENIK, Aleksander. Law, Morals and Defeasibility. Ratio Juris, v. 13, n. 3, p. 305-325, sep. 2000, p. 312.
} 
o que enseja a metáfora de que, como um cachorro, uma cadeia de razões, mais cedo ou mais tarde, morde o próprio rabo, denotando sua circularidade ${ }^{161}$.

Ademais, embora as razões jurídicas necessariamente entrem no cálculo de ponderação, isso não significa que sempre serão elas a preponderar na definição da solução, visto que, em alguns casos, considerações morais desempenham um papel no raciocínio jurídico tanto pela ponderação de razões baseadas em princípios; quanto pela imposição de exceção a regras. O que denota a defensabilidade da justificação jurídica ${ }^{162}$.

Assim, inobstante a vinculação à lei, dado o status especial de razões jurídicas, tendose em vista que razões morais entram na base de coerência, Peczenik concluirá que, finalmente, na ponderação entre razões morais e jurídicas, o fator determinante da solução será calcado em preferências e sentimentos pessoais lastreados em uma estrutura de herança cultural $^{163}$.

De forma que, embora sua teoria seja cognitivista quanto às proposições valorativas prima facie, já que são reconhecíveis a partir da herança cultural da sociedade, é não cognitivista quanto às proposições valorativas definitivas (all-things-considered): há liberdade para se ponderar consoante impressões e sentimentos pessoais e não se tem como saber de antemão o resultado a que se chegará.

Ou seja, o último passo de ponderação entre razões morais e jurídicas é, para ele, finalmente baseado em preferências pessoais e intuitivas e não há nenhuma relação de preferência única entre valores que implique uma resposta correta, mas há diversas maneiras nas quais se pode ponderar e sopesar as considerações relevantes.

\footnotetext{
161 "Here we approach the most profound problem of coherentist justification, that is, its circularity. If nothing is an unshakable foundation of knowledge and everything may be doubted, I need reasons for reasons for reasons ... etc. To avoid an infinite regress, a coherentist must accept circularity. Indeed, a coherent system of acceptances and preferences is like a network of argumentative circles, mostly quite big ones. Metaphorically, a chain of arguments, sooner or later, bites its own tail, and thus may be represented as a circle. In such a chain, $\mathrm{p}_{1}$ supports $\mathrm{p}_{2}, \mathrm{p}_{2}$ supports $\mathrm{p}_{3}$ etc... and $\mathrm{p}_{\mathrm{n}}$ supports $\mathrm{p}_{1}$. 'Support' is only explicable as a reasonable support: $\mathrm{p}_{2}$ follows from $p_{1}$ together with another premise, say $r_{1}$. This premise $r_{1}$ is reasonable, which implies that it is a member of another such circle. This circularity makes it impossible to logically prove that coherence renders truth. The claim that justification depends on coherence is not intended as an argument to prove to a skeptic that we are truthworthy. It is the claim that our justification for what we accept depends on a system of acceptance containing general claims about our competence and truthworthiness. When there is an adequate match between acceptance and reality, coherence converts to knowledge". PECZENIK, Aleksander. Scientia Iuris - An Unsolved Philosophical Problem. Ethical Theory and Moral Practice, v. 3, n. 3, p. 273-302, sep. 2000, p. 290291.

${ }^{162}$ HAGE, Jaap; PECZENIK, Aleksander. Law, Morals and Defeasibility. Ratio Juris, v. 13, n. 3, p. 305-325, sep. 2000, p. 305.

${ }^{163}$ PECZENIK, Aleksander. Law, Morality, Coherence and Truth. Ratio Juris, v. 7, n. 2, p. 146-176, jul. 1994, passim.
} 
Daí porque Amalia Amaya ${ }^{164}$ salienta que, para Peczenik, o Direito nem sempre é o “fim do problema", já que nem sempre ele nos dá uma resposta à questão de como se deve decidir o caso em questão e não há nenhuma diretriz que determine como melhor ponderar as várias considerações.

Embora os critérios de coerência possam guiar o julgador em uma ponderação racional de diversas razões conflitantes, finalmente, as preferências pessoais desempenhariam um papel decisivo sobre qual decisão tomar, entre julgamentos definitivos igualmente justificados e, como propôs MacCormick, também para Peczenik, o último passo de deliberação seria uma questão de preferências subjetivas, o que limitaria de forma importante a ambição coerentista de expandir o espaço de razões no Direito, bem como poderia gerar dúvidas, inclusive, se Peczenik conseguiu suplantar a visão positivista clássica sobre o espaço de razão no Direito dado o subjetivismo do autor sobre valor moral.

Com isso se nota o papel relevante, mas deveras limitado da coerência na objetividade da decisão judicial e mesmo em termos de racionalidade do processo decisório. A teoria coerentista de Peczenik é forte ${ }^{165}$ no sentido de que ele amplia a base de coerência, abarcando tanto razões morais quanto jurídicas, sendo necessária e suficiente para a justificação jurídica ${ }^{166}$.

Embora, como nota Amalia Amaya, a teoria coerentista de Peczenik tenha a vantagem de introduzir elementos, como os critérios de coerência, como ferramentas para o julgador, muitos de seus conceitos são deixados sem necessários esclarecimentos, tais como a relação que Peczenik estabelece entre coerência, correção, racionalidade e verdade ${ }^{167}$.

Também é patente a limitação de sua proposta coerentista se se deseja tomar a coerência como elemento que permita a conciliação entre ponderação e vinculação à lei, visto que, se em última análise são as preferências e emoções os fatores determinantes na

\footnotetext{
${ }^{164}$ AMAYA NAVARRO, Amalia. An inquiry into the nature of coherence and its role in legal argument. $\mathrm{PhD}$ Theses. Department of Law. European University Institute, 2006, p. 40-41.

${ }_{165}$ Poder-se-ia também classificar sua teoria coerentista como global. Apesar de o autor inicialmente apontar a tarefa do juiz como mais limitada em relação à do jurista, pois aquele se cingiria ao problema a se resolver, ao considerar que o juiz deve ter em vista o sistema jurídico como um todo e não apenas o relevante para se decidir um caso, vem finalmente esposar com Hage a ideia de que a melhor teoria coerentista do que Direito é, é parte da teoria coerentista de tudo e Mas, também com Hage, Peczenik reconhece que essa visão sobre a melhor teoria do Direito tem implicações dúbias: os conteúdos do Direito parecem relativos à moralidade pessoal e, dada a complexidade de se construir uma teoria coerentista de tudo, seria impossível determinar o que o Direito é. HAGE, Jaap; PECZENIK, Aleksander. Law, Morals and Defeasibility. Ratio Juris, v. 13, n. 3, p. 305-325, sep. 2000.

166 Notando a autora, quanto a isso, a mudança de Peczenik em relação a seu artigo com Alexy, como já apontado. AMAYA NAVARRO, Amalia. An inquiry into the nature of coherence and its role in legal argument. PhD Theses. Department of Law. European University Institute, 2006.

${ }_{167}$ AMAYA NAVARRO, Amalia. An inquiry into the nature of coherence and its role in legal argument. $\mathrm{PhD}$ Theses. Department of Law. European University Institute, 2006.
} 
ponderação de razões, a objetividade e a racionalidade do processo decisório, tendencialmente favorecidas pela coerência, nessa perspectiva teórica, mostram-se bastante limitadas.

\subsubsection{Teoria Coerentista de Ronald Dworkin}

A teoria coerentista de Ronald Dworkin está abarcada em sua teoria do direito como integridade, a despeito das críticas que lhe são dirigidas, seja por sua abordagem não apresentar efetivamente o conceito de coerência e tampouco os critérios de coerência ${ }^{168}$; seja porque, como diz Joseph Raz, um de seus maiores críticos, levanta-se dúvida sobre o real compromisso de Dworkin com a coerência ${ }^{169}$.

Não obstante, a coerência em Dworkin é parâmetro tanto para se decidir o conceito de Direito, o que ele é, quanto para a justificação das decisões judiciais, até porque a questão do que o Direito é e o que ele requer em um caso particular são questões idênticas para Dworkin, de modo que não há, em sua acepção, limites claros entre a teoria do direito e da adjudicação.

Destarte, Dworkin afasta as concepções convencionalista e pragmática, adotando o conceito de direito como integridade. A primeira exigiria consistência decisória com regras e a segunda a consistência política, em termos de razões estratégicas. Já o direito como integridade amplia a base coerentista, para além das regras, fazendo inserir razões políticas e, sobretudo, razões de princípio nas quais se baseia a concepção de coerência.

A primeira noção de coerência de Dworkin aparece em Taking Rights Seriously sob o binômio 'consistência articulada' (articulate consistency), como uma exigência da doutrina da responsabilidade, segundo a qual não se podem adotar decisões que pareçam corretas

\footnotetext{
${ }^{168}$ AMAYA NAVARRO, Amalia. An inquiry into the nature of coherence and its role in legal argument. $\mathrm{PhD}$ Theses. Department of Law. European University Institute, 2006.

${ }^{169}$ Raz lança também outras críticas a Dworkin no mesmo artigo em que levanta dúvidas sobre sua teoria coerentista: "His [Dworkin] position is as explained in this quotation: The law consists of those principles of justice and fairness and procedural due process which provide the best (i.e., morally best) set of sound principles capable of explaining the legal decisions taken throughout the history of the polity in question. Whether or not such principles display any degree of coherence, in the sense of interdependence, is an open question. Thus, while coherence may be a by-product of the best theory of law, a preference for coherence is not part of the desiderata by which the best theory is determined. The reason for thinking that Dworkin is not at all committed to the desirability of coherence is that his text is ambivalent and that while Dworkin argues at length that interpretations are necessarily evaluative, and that they try to show their object as the best of its kind, and that the interpretation of the law is committed to integrity, he never provides any reason whatsoever to suggest that coherence is a desideratum in correct interpretations... Three objections may be raised to the conclusion that Dworkin's theory of law contains no commitment to any degree of coherence. First, in the quotation above, while coherence is not specifically mentioned, it is implied in the reference to 'constructive interpretation', for as we saw above interpretation must, according to Dworkin, be not only coherent but monistic...". RAZ, Joseph. The relevance of coherence. Boston University Review, v. 72, n. 2, p. 273-231, mar. 1992, p. 317.
} 
isoladamente, mas que não podem ser inseridas em alguma teoria ampla de princípios gerais e políticas que é consistente com outras decisões também consideradas corretas ${ }^{170}$.

Assim, um argumento de princípio pode dar uma justificação a uma decisão particular sob a doutrina da responsabilidade apenas se o princípio pode ser demonstrado como consistente com decisões anteriores não corrigidas ou afastadas, e com decisões que se tomaria em circunstâncias hipotéticas. E Dworkin esclarece que a consistência articulada não diz respeito apenas à aplicação da regra particular anunciada em nome daquele princípio, mas na aplicação do próprio do princípio basilar.

Em Law's Empire, Dworkin postula que a justificação jurídica é um exercício de interpretação construtiva, uma vez que nosso Direito consistiria na melhor justificação de nossas práticas como um todo, consistindo na estória narrativa que torna tais práticas o melhor que possam ser. Ante tal conceito interpretativo do Direito, mister seria, para o autor, uma abordagem sobre a interpretação ${ }^{171}$.

A interpretação do Direito, como prática social, assemelha-se, para ele, à interpretação artística no sentido de que ambas objetivam a interpretar algo criado por pessoas e distinto delas, sendo formas de interpretação criativa, ou seja, têm por objetivo decifrar os propósitos ou intenções dos autores na elaboração da lei e na redação de romances. A interpretação criativa seria construtiva, já que os propósitos em questão não seriam do autor, mas do intérprete, podendo-se divisar três estádios de interpretação.

O primeiro estádio seria pré-interpretativo - o qual, a despeito da nomenclatura não, implique inexistência de interpretação, que se nota também nesse estádio -, em que o julgador identificaria as regras e padrões consensuais em uma comunidade. No estádio interpretativo, o intérprete estabelece alguma justificação geral para os elementos da prática identificados no estádio anterior.

Finalmente, no estádio pós-interpretativo ou reformador, o intérprete ajusta sua interpretação do que a prática realmente requer de modo a servir à justificação aceita no estádio interpretativo, ou seja, busca o equilíbrio entre a prática jurídica como a encontra e a melhor justificação daquela prática ${ }^{172}$. E nesse caso, o intérprete precisa de convicções quanto à justificação que ele propõe contar como uma interpretação da prática em vez de invenção de

\footnotetext{
${ }^{170}$ DWORKIN, Ronald. Taking Rights Seriously. Cambridge: Harvard University Press, 1978, p. 88.

${ }^{171}$ DWORKIN, Ronald. Law's Empire. Cambridge, MA: Harvard University Press, 1986, p. 50 et seq.

${ }^{172}$ Acerca da correlação entre a teoria coerentista de Dworkin e o método de equilíbrio reflexivo postulado por Rawls, vide: AMAYA NAVARRO, Amalia. An inquiry into the nature of coherence and its role in legal argument. PhD Theses. Department of Law. European University Institute, 2006, p. 46.
} 
algo novo, tendo em vista que o objetivo da interpretação é tornar o objeto ou prática interpretada o melhor que possa ser.

Dworkin ainda traça a similitude entre Direito e Literatura a partir de sua noção de romance em cadeia, consistente em um romance seriado cuja elaboração é feita por um grupo de roteiristas. Cada roteirista interpretaria os capítulos que recebeu, adicionando um novo capítulo, que é então transmitido ao próximo roteirista e assim sucessivamente. Sendo que cada um teria a tarefa de escrever seu capítulo de modo a tornar o romance o melhor que possa ser, ou seja, cada um objetivaria a fazer um único romance do material que lhe fora dado, buscando fazer um trabalho que parecesse de um único autor em vez de diversos, como é o caso ${ }^{173}$.

Assim, buscar-se-ia a maior coerência possível, e a complexidade dessa tarefa se assemelharia à complexidade de decidir um caso difícil no direito como integridade, devendose discernir entre o que conta como continuar o romance e não começar um novo, conforme exposto.

Para tanto, a interpretação deveria ser testada em duas dimensões. A primeira dimensão é a de ajuste, ou seja, admitem-se apenas interpretações ajustadas ao sentido estabelecido, que tenham coerência com o que foi posto e, no Direito, tal dimensão implicaria coerência da decisão com as práticas sociais.

A interpretação ainda poderia ser testada em uma segunda dimensão: de fundo ou substancial, que permitiria decidir qual das leituras elegíveis torna o trabalho o melhor, definitivamente, à luz de uma moralidade política da comunidade.

Dworkin reconhece que a interpretação no Direito é uma ponderação delicada entre convicções políticas de diferentes tipos, por isso, ele cria um juiz imaginário de poder intelectual sobre-humano e paciência, que aceite o direito como integridade. A esse juiz chama de Hércules, caracterizando-o como um juiz cuidadoso, e dotado de método ${ }^{174}$.

Então, tendo-se em vista o direito como integridade, Hércules decidiria começando pelo estabelecimento de diversas candidatas à melhor interpretação de casos precedentes, o que demonstra sua perspectiva de inferência à melhor explicação. Então, estabeleceria um rol de interpretações possíveis, testando cada uma pelo questionamento de se um funcionário político poderia tê-la dado os vereditos dos casos anteriores se estivesse conscientemente e coerentemente aplicando os princípios que formam a interpretação do caso em discussão.

\footnotetext{
${ }^{173}$ DWORKIN, Ronald. Law's Empire. Cambridge, MA: Harvard University Press, 1986, p. 229 et seq.

${ }^{174}$ DWORKIN, Ronald. Law's Empire. Cambridge, MA: Harvard University Press, 1986, p. 240.
} 
Isso porque Hércules deve tratar o legislador como um autor anterior a ele na cadeia de Direito, embora um autor com poderes especiais e responsabilidades diferentes da sua própria, e ele verá seu próprio papel como fundamentalmente criativo, como um parceiro continuando a desenvolver, no que ele crê ser a melhor maneira, o esquema legal que o Congresso começou. Ele se perguntará, então, qual leitura do ato apresenta a história política incluindo e circundando aquela lei na melhor luz ${ }^{175}$. Sua visão de como a lei deveria ser lida dependerá em parte do que certo congressista disse quando a debateu e sua tarefa é justificar a estória como um todo, não apenas seu fim.

Assim, ele deve buscar para cada lei alguma justificação que a torne coerente com o Direito como um todo. Isso significa que ele deve perguntar-se qual combinação de quais princípios e políticas, com quais atribuições de importância relativa, quando conflitam, provê a melhor explicação para o que as palavras da lei plenamente exigem, já que o princípio adjudicativo de integridade postula, na medida do possível, que se veja o Direito como um todo coerente e estruturado ${ }^{176}$, a partir da presunção de que o Direito é criado por um único autor que seria a comunidade personificada. Mas essa seria uma característica apenas de uma comunidade de princípio, o que não ocorre em comunidades de fato ou por convenção.

Dworkin diferencia, portanto, entre três tipos de comunidade consoante a perspectiva das pessoas em relação ao tipo comunitário a que pertençam. Uma comunidade de circunstância se caracterizaria como uma sociedade de fato, em que as pessoas se ligariam em razão de condições genéticas, geográficas ou históricas, sem constituir verdadeira comunidade associativa, mas pautada apenas em objetivos egoísticos.

A comunidade de convenção se caracterizaria pela aceitação de seus membros em obedecer às regras estabelecidas naquela comunidade, sem a percepção da existência de princípios subjacentes justificadores das regras postas e que poderiam ensejar outros direitos e obrigações para além dos constantes nas regras explicitadas.

Já na comunidade de princípio, as pessoas aceitam ser governadas por princípios comuns e não apenas por regras impostas por um compromisso político. Este seria o caso da comunidade de convenção. E os membros desse tipo de sociedade de princípio aceitam que

\footnotetext{
${ }^{175}$ DWORKIN, Ronald. Law's Empire. Cambridge, MA: Harvard University Press, 1986, p. 313.

${ }^{176}$ Dworkin distingue entre o princípio de integridade na legislação e na adjudicação. O primeiro exige que os que legislam mantenham o direito coerente em princípio. E o princípio de integridade na adjudicação exige que os responsáveis por decidir o que é o direito vejam-no e apliquem-no como coerente naquela forma. Assim, o princípio adjudicativo da integridade exige que o juiz torne o direito coerente como um todo. Isso não significa que Dworkin não reconheça compartimentalizações entre ramos do direito, mas por seu compromisso com a integridade, entende que Hércules deverá buscar uma interpretação construtiva da compartimentalização, ou seja, deve tentar encontrar uma explicação da prática de dividir o direito em ramos que apresente aquela prática à sua melhor luz. DWORKIN, Ronald. Law's Empire. Cambridge, MA: Harvard University Press, 1986, passim.
} 
seus direitos e deveres políticos não são exauridos pelas decisões particulares que suas instituições políticas tomaram, mas dependem, mais geralmente, do esquema de princípios que aquelas decisões pressupõem e endossam e que refletem a pretensão coerentista de Dworkin de uma comunidade personificada, em que se fale uma única voz.

Essa seria, assim, uma sociedade política que aceita a integridade como uma virtude política com as seguintes vantagens: a integridade proveria proteção contra parcialidade ou fraude ou outras formas de corrupção pública, exigindo a observância de princípios comuns aos casos a se decidir; bem como contribuiria à eficiência do Direito, permitindo ampliação ou restrição interpretativa à luz dos princípios, já que há a aceitação pelas pessoas de que são governadas não apenas por regras explícitas, estabelecidas nas decisões políticas anteriores, mas também por outros padrões emanados por princípios que essas decisões presumem.

Assim, o Direito como integridade requeria que um juiz testasse sua interpretação de qualquer parte da grande rede de estruturas políticas e decisões de sua comunidade perguntando se sua interpretação poderia formar parte de uma teoria coerente justificando a rede como um todo. Dworkin reconhece que essa perspectiva coerentista global seria inexequível pragmaticamente, visto que nenhum juiz real conseguiria uma interpretação de todo o Direito da comunidade de uma vez e, por tal razão, presume um juiz hercúleo de talentos sobre-humanos e tempo infindável.

Às críticas céticas quanto à impossibilidade real desse julgador, Dworkin responde no sentido de que um juiz real pode imitar Hercules de uma forma limitada, devendo buscar qual interpretação apresenta o Direito como o melhor que possa ser do ponto de vista da moralidade política substancial. E aqui nota-se que, tanto quanto MacCormick e Peczenik, Dworkin amplia a base coerentista para incluir aspectos morais ${ }^{177}$.

Essa perspectiva global levanta dois problemas: o fato de que o Direito nem sempre atende efetivamente em todos os seus ramos a princípios gerais e Raz, inclusive, salienta que o pluralismo político impele a posições conflitantes, o que não é um problema, mas uma característica de sociedades democráticas; e a dificuldade em se alcançar a coerência em uma perspectiva holística.

Quanto ao primeiro problema, Dworkin postula que o princípio adjudicativo da integridade exige que o juiz torne o Direito coerente como um todo, na medida em que pode, e isso pode ser mais bem feito ignorando-se fronteiras acadêmicas entre ramos do Direito,

\footnotetext{
${ }^{177}$ Isso denota que o modelo coerentista de justificação de Dworkin é substancial e não meramente formal. AMAYA NAVARRO, Amalia. An inquiry into the nature of coherence and its role in legal argument. $\mathrm{PhD}$ Theses. Department of Law. European University Institute, 2006, p. 74.
} 
embora sendo o direito como integridade interpretativo, não se deva ignorar tal compartimentalização, que é uma característica da prática jurídica.

Assim, Dworkin admite em alguns casos uma justificação 'parcial', pois uma justificação 'completa' estaria para além do que os juízes reais poderiam alcançar, e o que uma interpretação razoável da prática jurídica real poderia acomodar ${ }^{178}$. O que pareceria levar ao coerentismo local. No entanto, isso não implica que ele se contente com essa visão - ele defende, inclusive como parte de sua proposta de integridade que Hércules busque uma interpretação construtiva da compartimentalização, ou seja, tente encontrar uma explicação da prática de dividir o Direito em departamentos que apresente aquela prática à sua melhor luz, e, ao postular que juízes reais devam imitar Hércules, a despeito de suas naturais limitações, mantém o modelo global como meta, embora o local seja muitas vezes o faticamente alcançável $^{179}$.

No que diz respeito à sua perspectiva holística, em razão de que o coerentismo global de Dworkin envolveria um compromisso irrestrito com o 'holismo' sobre a justificação, no sentido de que a justificação de qualquer crença particular dependeria da justificação do sistema total de crenças ao qual tal crença pertence, Amalia Amaya diz ser uma proposta psicologicamente implausível, pois nenhum juiz real teria tal amplitude de percepção e atuação $^{180}$.

Em verdade, Dworkin admite que Hércules sabe que o Direito é longe de perfeitamente consistente em um princípio global. Mas reforça que o princípio adjudicativo de integridade exige que Hércules enxergue, na medida do possível, o Direito como um todo coerente e estruturado se se deseja tratar uma comunidade como uma associação de princípio, como uma comunidade governada por uma única e coerente visão de justiça, igualdade e devido processo legal ${ }^{181}$.

\footnotetext{
${ }^{178}$ AMAYA NAVARRO, Amalia. An inquiry into the nature of coherence and its role in legal argument. $\mathrm{PhD}$ Theses. Department of Law. European University Institute, 2006, p. 71.

${ }^{179}$ Amalia Amaya acrescenta que o modelo de coerência de Dworkin é baseado em uma concepção de coerência sistêmica, em vez de relacional. E acrescenta que os modelos sistêmicos de coerência são objetáveis na medida em que, implausivelmente, requerem um alto grau de coerência em dado domínio, quando há disputa política na forma e desenvolvimento do Direito, o que torna altamente problemático requerer que o Direito seja coerente como uma condição para a justificação de uma única decisão jurídica como correta. AMAYA NAVARRO, Amalia. An inquiry into the nature of coherence and its role in legal argument. $\mathrm{PhD}$ Theses. Department of Law. European University Institute, 2006, p. 73.

${ }^{180}$ Amaya ainda salienta a diferença entre coerência sistêmica e coerência global. Em síntese, poder-se-ia dizer que a coerência global é a coerência com todo o sistema jurídico; a local, a coerência com certa área do Direito. Já a coerência relacional diz respeito à decisão ser coerente com um corpo de normas, que não precisam ser coerentes; enquanto a coerência sistêmica exige que a decisão pertença a um corpo coerente de normas e, aqui, o corpo normativo precisa ser coerente. AMAYA NAVARRO, Amalia. An inquiry into the nature of coherence and its role in legal argument. PhD Theses. Department of Law. European University Institute, 2006, p. 130.

${ }^{181}$ DWORKIN, Ronald. Law's Empire. Cambridge, MA: Harvard University Press, 1986, passim.
} 
E a vantagem seria de que essa perspectiva do direito como integridade garantiria a legitimidade política do exercício da coação estatal, na presunção coerentista de uma comunidade personificada em que se falasse em uma única voz. Assim, a integridade não seria apenas consistência no sentido formal de se decidir casos semelhantes de modo semelhante, por repetição de decisões anteriores, mas a exigência de que os padrões públicos de uma comunidade fossem feitos e vistos, na medida do possível, como expressando um único esquema coerente de justiça e igualdade, admitindo-se para isso em alguns casos o afastamento de uma linha estrita de decisões anteriores em busca de fidelidade a princípios concebidos como mais fundamentais ao esquema como um todo ${ }^{182}$.

$\mathrm{O}$ que implica que a integridade enseja a um juiz ser abrangente e imaginativo na busca por coerência com princípio fundamental, tendo-se em vista que o programa que o direito como integridade dispõe aos juízes para decidir hard cases é essencialmente, não apenas contingentemente, interpretativo.

Desse modo, a integridade requeria não recapturar, mesmo para o presente, os ideais ou propósitos práticos de políticos que criaram o Direito, mas justificar o que fizeram (às vezes incluindo o que disseram) em uma estória total, ou seja, é a busca dos princípios norteadores da elaboração da regra que devem ser aplicados no caso a se decidir.

E isso enseja o desafio cético sobre a objetividade no processo interpretativo de Hércules, ou seja, a arguição da inexistência de razões objetivas para preferir uma interpretação a outra, ou para selecionar uma delas como a melhor. No entanto, como aponta Amalia Amaya ${ }^{183}$ a justificação coerentista de Dworkin está conceitualmente ligada à verdade jurídica em termos de coerência. Para ela, a teoria interpretativa de Dworkin envolve um compromisso com uma 'teoria coerentista de verdade', segundo a qual se uma posição particular do Direito é verdadeira depende se ela pertence à teoria mais coerente que ajuste e justifique o Direito posto (dimensão de ajuste e substancial ou de justificação da interpretação acima referidas). É a coerência com o conjunto de crenças interpretativas sobre o Direito e a moralidade política que implicam verdade jurídica.

A visão de Dworkin é de verdade como coerência ${ }^{184}$ : proposições jurídicas são verdadeiras se são coerentes com a teoria que melhor explica e justifica o Direito posto e a verdade no domínio jurídico não seria senão justificação. As razões de coerência permitiriam

\footnotetext{
${ }^{182}$ DWORKIN, Ronald. Law's Empire. Cambridge, MA: Harvard University Press, 1986, p. 219 et. seq.

${ }_{183}$ AMAYA NAVARRO, Amalia. An inquiry into the nature of coherence and its role in legal argument. $\mathrm{PhD}$ Theses. Department of Law. European University Institute, 2006, p. 81 et. seq.

${ }^{184}$ DWORKIN, Ronald. Law's Empire. Cambridge, MA: Harvard University Press, 1986, p. 94.
} 
a seleção de uma única melhor decisão como justificada. A famosa e tão criticada tese da resposta correta ${ }^{185-186}$.

Dessa forma, Dworkin endossa uma versão coerentista forte, por considerar a coerência como uma condição necessária e suficiente para a justificação jurídica, uma vez que a coerência permite restringir o número de alternativas plausíveis, bem como selecionar uma delas como justificada não apenas no Direito, mas também defensável do ponto de vista da moralidade política ${ }^{187}$.

Conforme Amalia Amaya, se MacCormick e Peczenik parecem cientes dos limites da razão no Direito, levando a uma concordância demasiada com o cético, Dworkin teria subestimado os limites da razão prática, minimizando o desafio cético de discricionariedade forte e não o enfrentando como seria de se esperar da proposta coerentista da justificação jurídica $^{188}$.

\subsubsection{Teoria coerentista de Susan Hurley}

Conforme David Zorrilla ${ }^{189}$, a concepção teórica coerentista postula a possibilidade de elaboração de uma teoria que apresente da melhor maneira possível como coerentes as relações entre as razões para a ação que entram em conflito no caso a ser decidido ${ }^{190}$. No caso

${ }^{185}$ AMAYA NAVARRO, Amalia. An inquiry into the nature of coherence and its role in legal argument. $\mathrm{PhD}$ Theses. Department of Law. European University Institute, 2006, p. 90.

${ }^{186}$ Entre as abordagens críticas: KRESS, Kenneth. Why No Judge Should Be a Dworkinian Coherentist. Texas Law Review. V. 77, p. 1375-1427, 1999.

${ }^{187}$ Quanto à teoria coerentista de Dworkin, Amalia Amaya sintetiza: “A mi modo de ver, Dworkin sostiene una teoría coherentista de la justificación según la cual una decisión jurídica está justificada si es coherente con el conjunto de principios que mejor explica y justifica la práctica jurídica, a la luz de una teoría de la moralidad política. Dworkin define no sólo la justificación jurídica también - me parece - el concepto de verdad en el Derecho en términos coherentistas. La teoría interpretativa del Derecho de Dworkin está comprometida con una teoría de la verdad como coherencia según la cual una proposición jurídica particular es verdadera si pertenece a la teoría que explica y justifica el Derecho de manera más coherente. Por lo tanto, según Dworkin, tanto la justificación de las proposiciones jurídicas como la verdad de las mismas dependen de su coherencia con un conjunto de creencias interpretativas acerca del Derecho y de la moralidad política. Las razones de coherencia, desde este punto de vista, nos permiten identificar (en la mayor parte de los casos) una única respuesta como justificada así como determinar de manera completa las condiciones de verdad de las proposiciones normativas en el Derecho". AMAYA NAVARRO, Amalia. La Coherencia en el Derecho. Doxa, no prelo. Disponível em: <http://papers.ssrn.com/sol3/papers.cfm?abstract_id=2049990>. Acesso em: 16 mar. 2012.

188 AMAYA NAVARRO, Amalia. An inquiry into the nature of coherence and its role in legal argument. $\mathrm{PhD}$ Theses. Department of Law. European University Institute, 2006, p. 101-102.

189 ZORRILLA, David Martínez. Conflictos Constitucionales, Ponderación e Indeterminación Normativa. Tesis Doctoral. Universidad Pompeu Fabra, Barcelona, 2004, p. 277 et. seq.

${ }^{190}$ Segundo Claudio Michelon, “... o papel da coerência na argumentação jurídica é fundamentalmente o de identificar princípios jurídicos (e separá-los de princípios meramente morais ou políticos que um determinado julgador ou doutrinador possa considerar obrigatórios). De fato, uma boa parte da argumentação fundada em princípio pode ser considerada simplesmente como uma instância de busca de um ideal de coerência do sistema jurídico. Em segundo lugar, a coerência oferece uma forma de lidar com a (aparente) pluralidade de princípios 
da perspectiva coerentista de Susan Hurley - no contexto do sistema jurídico de common Law -, tenta-se por meio da deliberação encontrar a teoria que melhor explique as relações entre as razões que sustentam as alternativas em conflito, e a resposta para tal conflito será a favorecida por esta teoria. No entanto, o principal problema está justamente na elaboração ou descobrimento da teoria considerada como a melhor, que será de fundamental importância para a deliberação.

A deliberação supõe um processo de construção de hipóteses acerca do conteúdo da função de coerência que permite partir das alternativas estabelecidas por cada uma das razões em conflito e chegar a uma ordenação definitiva (all-things-considered). Nesse processo deliberativo, para se determinar a importância das razões conflitantes do caso a decidir, é preciso recorrer à apreciação de casos paradigmáticos reais ou hipotéticos, nos quais incidam as mesmas razões do caso a ser julgado. Considerando-se como paradigmático um caso que conte com amplo consenso sobre sua resolução, independentemente de sua correção em termos objetivos. Ou seja, não significa que se trate de um caso cuja solução seja considerada como a melhor, mas que seja consensualmente aceita ${ }^{191}$.

Susan Hurley salienta que nem todos os casos reais decididos são paradigmáticos, uma vez que alguns podem não contar com o consenso da comunidade jurídica relativamente à decisão tomada, havendo posições discordantes. Por outro lado, há casos paradigmáticos que não foram efetivamente decididos, uma vez que são hipotéticos, ou seja, não reais, mas se trata de respostas consensuais a respeito de como certos casos deveriam ser resolvidos.

A importância desses casos paradigmáticos, portanto, é de caráter normativo, no sentido de guiar a decisão do caso em questão, tendo-se por base julgamentos em casos paradigmáticos em que razões jurídicas aplicáveis fossem conflitantes e que tivessem semelhança com o caso a ser decidido, isso com base no requerimento de consistência geral de que casos relevantemente similares, a respeito de doutrinas jurídicas aplicáveis e circunstâncias distintivas, devam ser similarmente resolvidos; que se trata do requerimento fraco da teoria coerentista de tratar casos semelhantes de forma semelhante ${ }^{192}$.

inconciliáveis. Todavia há certos aspectos da argumentação fundada em princípios (conforme ocorre na prática dos tribunais) que não podem ser reduzidos à idéia [sic] de coerência e, nesses casos, seria necessário buscar um outro ideal racional do sistema jurídico para arbitrar entre princípios...”. MICHELON, Claudio, Principles and Coherence in Legal Reasoning (Princípios e Coerência na Argumentação Jurídica) (Portuguese). U. of Edinburgh School of Law Working Paper, n. 2009/08, 31 mar. 2009. Disponível em: <http://ssrn.com/abstract=1371140>. Acesso em: 01 mar. 2011.

${ }^{191}$ ZORRILLA, David Martínez, Conflictos Constitucionales, Ponderación e Indeterminación Normativa. Tesis Doctoral. Universidad Pompeu Fabra, Barcelona, 2004, 2004, p. 281.

192 HURLEY, Susan L. Coherence, hypothetical cases, and precedent. Oxford Journal of Legal Studies, p. 221251, 1990, passim. 
Assim, a questão de uma abordagem coerentista não é eliminar a discordância teórica com final aberto, mas possibilitar soluções a casos de conflito de princípios ou razões que permitam uma solução coerente tendo-se em vista casos reais e hipotéticos ${ }^{193}$, o que diria respeito no sistema jurídico a que a autora está filiada à observância de precedentes judiciais.

No entanto, consoante expõe a própria autora, esse processo deliberativo proposto é altamente complexo e sua aplicação é dotada de alto grau de dificuldade, dada a multiplicidade de casos reais ou hipotéticos que poderiam esclarecer um conflito particular, determinando como as alternativas estão relacionadas.

O que tornaria necessário atenção a áreas da prática jurídica cuja relação à questão em caso não seja óbvia, a fim de se elucidar o efeito de tipos particulares de circunstâncias com implicação no peso dos princípios em caso e de seus propósitos, o que exige capacidade distintiva, sensibilidade e percepção das práticas jurídicas ${ }^{194}$.

E, ainda, não há um ponto em que se esteja certo acerca do fim da teorização, já que se pode considerar exaurida a relação de casos - reais ou hipotéticos - que possam ter implicação sobre o caso em questão e, entretanto, surgir um novo caso ou algum mais sutil ou mais radical que exija um refinamento ou mesmo abandono da teoria ${ }^{195}$.

O modelo deliberativo proposto por Susan Hurley consiste em cinco estádios ou etapas. A primeira etapa consiste na especificação do problema, por meio da identificação das

\footnotetext{
${ }^{193}$ Consoante Robert Nozik "There is a connection between using principles as devices for reaching correct decisions and using them to constrain the influence of undesired or irrelevant factors, such as personal preference. We want to decide or judge a particular case by considering all and only the relevant reasons concerning it. A general principle, which forces us to look at other actual and hypothetical cases, can help test whether a reason $R$ we think is relevant or conclusive in this case really is so. Would $R$ be relevant or conclusive in another case? If reasons are general, we can check $R$ 's force in this case by considering other cases. Moreover, deciding via a general principle can call our attention to other relevant reasons, ones we have not yet noticed in this case. Looking at another case where feature $R$ does not have great force might lead us to notice another feature $F$ that the present case has, and it is $R$ and $F$ together that have great force. (If we hadn't looked at the other case, we might have thought $R$ alone was enough.) [...] Notice that this use of hypothetical or other actual cases to test a judgment in this case already assumes that reasons are general. If we assume that things happen or hold for a reason (or cause) and that reasons (or causes) are general, then a general principle, perhaps defeasible, can be formulated to capture this reason, to explain why an event the scientist studies occurs or why a particular judgment about a case is correct". NOZIK, Robert. The Nature of Rationality. Princeton, New Jersey: Princeton University Press, 1993, p. 7-8.

${ }^{194}$ Um exemplo disso é dado por Neil MacCormick ao levantar três casos aparentemente com pouca semelhança, como o de náufragos que sacrifiquem um membro do grupo que esteja obstando o resgate dos demais; um montanhista que sacrifique a vida de um colega com probabilidade mínima de sobrevida e que exporia a risco certo a vida do outro; e, finalmente, um caso de gêmeas xifópagas em que, mantidas vivas, ambas teriam morte próxima praticamente certa e, procedendo-se à separação, seria quase certo que uma morreria, mas a outra sobreviveria. Embora não pareçam semelhantes, quando se nota que os três casos envolvem situações em que uma pessoa aparentemente levada à morte inevitável se torna causa potencial de morte de outra pessoa cuja vida possa ser mantida, a semelhança entre os casos revela-se. MACCORMICK, Neil. Rethoric and the Rule of Law A Theory of Legal Reasoning. Oxford: Oxford University Press, 2005, p. 210.

${ }^{195}$ HURLEY, Susan. Natural Reasons: personality and polity. Oxford University Press: New York, 1989, p. 210-211 e 215 .
} 
alternativas em questão e as distintas razões relevantes que se aplicam a cada uma delas, bem como se ordenam as alternativas em conflito.

Já na segunda etapa é feito um exame mais detido das razões em conflito, buscando-se identificar o propósito de cada razão, para o fim de se determinar a importância de cada razão no caso a decidir. David Zorrilla entende que nessa etapa não se está estritamente perante normas jurídicas, mas ante o que se costumou chamar 'razões subjacentes', a respeito das quais haveria controvérsia se são ou não normas jurídicas, sob parâmetros positivistas e, se, pois, formam parte do sistema jurídico sob a concepção positivista do Direito ${ }^{196-197}$.

De todo modo, entende-se por razões subjacentes, as considerações, propósitos, finalidades e princípios morais que sirvam de fundamento da norma ou normas consideradas, tendo-se em vista que a norma tem sempre algum fundamento ou obedece a alguma finalidade ou propósito estabelecido. E a definição de quais são essas razões subjacentes, salvo quando há referências expressas na exposição de motivos de uma lei, por exemplo, seria para ele o resultado de um ato de vontade do intérprete que imputa (e não descobre) tais 'razões' ${ }^{198}$, o que não deixa de levar ao problema da arbitrariedade.

$\mathrm{Na}$ terceira etapa do processo deliberativo proposto por Hurley, analisam-se outras situações reais, assuntos já decididos, ou hipotéticas, experimentos mentais, nas que sejam aplicáveis as mesmas razões do caso a decidir e que sejam considerados como casos paradigmáticos, no sentido acima explicado de um caso cuja solução seja clara ou evidente e sobre a qual haja amplo consenso.

Embora se pondere que a resolução ser clara não significa que não possa ser incorreta, não obstante seja da natureza de uma abordagem coerentista o que deveria ser feito, em termos de coerência com casos decididos em geral, que nem todos os casos definidos possam ser errados ${ }^{199}$. Assim, nesse terceiro passo, faz-se a reunião de dados para buscar outras

\footnotetext{
196 Consoante David Zorrilla, a linha coerentista ajusta-se a uma concepção pós-positivista ou mesmo antipositivista do Direito: “... para Hurley tienen la consideración de 'razones para la acción en el razonamiento jurídico', indistintamente, tanto elementos como las normas jurídicas (preceptos legales y constitucionales, precedentes judiciales, etc.), esto es, elementos identificables a través de criterios positivistas como por ejemplo la regla de reconocimiento, como también otros elementos como las doctrinas de los juristas, los principios (entendidos à la Dworkin), las políticas (policies), las prácticas de las instituciones, etc., que no constituyen 'derecho' (o fuente de derecho, para ser más precisos) de acuerdo con los parámetros del positivismo jurídico". ZORRILLA, David Martínez. . Conflictos Constitucionales, Ponderación e Indeterminación Normativa. Tesis Doctoral. Universidad Pompeu Fabra, Barcelona, 2004, p. 278.

${ }^{197}$ A defesa da juridicidade de tais razões é feita por Juliano Maranhão. Vide: MARANHÃO, Juliano Souza de Albuquerque. Inclusivismo Lógico. Tese de livre-docência, Departamento de Filosofia e Teoria Geral do Direito, Universidade de São Paulo, São Paulo, 2010.

198 ZORRILlA, David Martínez. ZORRILLA, David Martínez. Conflictos Constitucionales, Ponderación e Indeterminación Normativa. Madrid: Marcial Pons, 2007, p. 256.

${ }^{199}$ HURLEY, Susan L. Coherence, hypothetical cases, and precedent. Oxford Journal of Legal Studies, p. 221$251,1990$.
} 
questões para as quais as razões do segundo estádio se aplicam, com vistas a uma aplicação coerente das razões no caso em questão.

A quarta etapa considera-se como o cerne do processo deliberativo, pois nela se elaboram hipóteses teóricas sobre os fundamentos das soluções dos casos paradigmáticos selecionados na terceira etapa. Trata-se, pois, do estádio de teorizar, de buscar hipóteses que forneçam resoluções de questões encontradas no estádio anterior, havendo uma tentativa de formulação de hipóteses sobre as relações entre as razões conflitantes sob várias circunstâncias diferentes.

Para tanto, examinam-se circunstâncias distintivas ou dimensões que contribuam para aumentar ou diminuir o peso de uma das razões conflitantes em relação à outra. A repercussão das distintas razões nos casos paradigmáticos auxilia o julgador a considerar em que medida oferecem fundamento para cada uma das decisões possíveis nas circunstâncias do caso a decidir e, por conseguinte, a determinar qual a alternativa com preponderância em tais circunstâncias, na medida em que o caso a se decidir apresente ou não certas propriedades.

Finalmente, na quinta etapa vislumbram-se as consequências das melhores hipóteses às que se chegou para o caso em questão e aplica-se a hipótese sobre relações entre as razões aplicáveis às circunstâncias presentes no caso em questão. Assim, as consequências que a melhor das hipóteses obtida na quarta etapa determinam definirão a solução para o caso em questão, de modo que a hipótese é uma especificação parcial de uma função de coerência que leva dos elencos de alternativas envolvendo várias circunstâncias ou dimensões das razões conflitantes para uma ordenação definitiva, levando à determinação de qual das alternativas tem prevalência no caso a se decidir. O que resulta em uma matriz deliberativa, cujo modelo é conforme segue ${ }^{200}$ :

\begin{tabular}{|l|l|l|l|}
\hline MATRIZ DELIBERATIVA & $\begin{array}{l}\text { Razão } \\
\text { X }\end{array}$ & $\begin{array}{l}\text { Razão } \\
\text { Y }\end{array}$ & $\begin{array}{l}\text { Solução definitiva (all-things- } \\
\text { considered) }\end{array}$ \\
\hline Caso em questão & alt a & alt b & $?$ \\
alt b & alt a & \\
\hline Casos reais paradigmáticos & alt d & alt c & alt c \\
& alt c & alt d & alt d \\
\end{tabular}

${ }^{200}$ HURLEY, Susan L. Coherence, hypothetical cases, and precedent. Oxford Journal of Legal Studies, p. 221$251,1990$. 


\begin{tabular}{|l|l|l|l|}
\hline & $\begin{array}{l}\text { alt } \mathrm{e} \\
\text { alt } \mathrm{f}\end{array}$ & $\begin{array}{l}\text { alt } \mathrm{f} \\
\text { alt } \mathrm{e}\end{array}$ & $\begin{array}{l}\text { alt } \mathrm{e} \\
\text { alt } \mathrm{f}\end{array}$ \\
\hline Casos hipotéticos & alt $\mathrm{g}$ & alt $\mathrm{h}$ & alt $\mathrm{h}$ \\
paradigmáticos & alt $\mathrm{h}$ & alt $\mathrm{g}$ & alt $\mathrm{g}$ \\
& alt $\mathrm{j}$ & alt $\mathrm{i}$ & alt $\mathrm{j}$ \\
& alt $\mathrm{i}$ & alt $\mathrm{j}$ & alt $\mathrm{i}$ \\
& etc. & & \\
\hline
\end{tabular}

Entende-se por "alt" a alternativa determinada por cada razão em caso. Do que se nota que, sendo as razões para a solução conflitantes, as alternativas que cada uma determina para a solução do caso são diametralmente opostas, prevalecendo a alternativa determinada pela razão preponderante.

Essa matriz deliberativa representa a etapa final, já preenchidas as etapas anteriores. Para ilustrar a aplicação dessa teoria e a construção da matriz deliberativa em cada etapa do processo deliberativo, será usado um exemplo fornecido por David Zorrilla com base em Susan Hurley.

O exemplo de Zorrilla ${ }^{201}$ considera um caso hipotético de colisão entre liberdade de informação e direito à honra, em uma decisão em que se informam certos fatos considerados verdadeiros e que afetem negativamente a respeitabilidade e a imagem pública de uma pessoa, havendo um conflito entre razões que ordenam diversamente as alternativas entre a prevalência do direito à honra ou à liberdade de expressão. A primeira etapa, consistente na identificação do problema seria representada da seguinte forma:

\begin{tabular}{|l|l|l|l|}
\hline $\begin{array}{l}\text { MATRIZ } \\
\text { DELIBERATIVA }\end{array}$ & Hnformação & Solução \\
\hline Caso em conflito & $\begin{array}{l}\text { Alternativa A } \\
\text { Alternativa B }\end{array}$ & $\begin{array}{l}\text { Alternativa B } \\
\text { Alternativa A }\end{array}$ & $?$ \\
\hline
\end{tabular}

Na segunda etapa, seriam determinadas as razões subjacentes a cada uma das razões acima (ou normas jurídicas na acepção de Zorrilla) que ordenam as alternativas de maneira diversa. $\mathrm{O}$ autor parte do pressuposto de que a liberdade de informação tem por base a

${ }^{201}$ ZORRILLA, David Martínez. Conflictos Constitucionales, Ponderación e Indeterminación Normativa. Tesis Doctoral. Universidad Pompeu Fabra, Barcelona, 2004, p. 292 et. seq. 
formação de uma opinião pública livre, o que seria corolário da democracia e, para que se possam expressar livremente ideias e opiniões, não poderia haver censuras acerca dos fatos que acontecem.

Assim, toma-se hipoteticamente a formação de uma opinião pública livre como a razão para a liberdade de informação. Por outro lado, quanto ao direito à honra, embora tenha fundamento discutível, seria assumido que a imagem e a projeção pública afetam a dignidade de uma pessoa, e seria a dignidade o fundamento para o direito à honra, o que levaria a um preenchimento na matriz deliberativa:

\begin{tabular}{|l|l|l|l|}
\hline MATRIZ & $\begin{array}{l}\text { Informação } \\
\text { (opinião pública) }\end{array}$ & $\begin{array}{l}\text { Honra } \\
\text { (dignidade) }\end{array}$ & Solução \\
\hline Caso em conflito & $\begin{array}{l}\text { Alternativa A } \\
\text { Alternativa B }\end{array}$ & $\begin{array}{l}\text { Alternativa B } \\
\text { Alternativa A }\end{array}$ & $?$ \\
\hline
\end{tabular}

$\mathrm{Na}$ terceira etapa do processo, foram selecionados pelo autor quatro casos hipotéticos paradigmáticos: a) a informação sobre a aprovação de uma concessão de serviço público por político, mediante propina; caso em que, embora a notícia afetasse negativamente a imagem pública do político, deveria prevalecer a liberdade de informação, tendo-se em vista a grande relevância dos fatos para a opinião pública; b) em um segundo caso hipotético, haveria notícia sobre atividades de uma pessoa pública que afetassem sua imagem pública, mas não fossem atinentes a assunto de interesse público, o que poderia ser exemplificado por um caso de adultério cometido pela pessoa pública.

Neste caso, hipoteticamente, prevaleceria o direito à honra sobre a liberdade de informação, já que a honra seria afetada e, no entanto, não haveria contribuição à formação da opinião pública; c) em um terceiro caso, seria noticiada a atividade de uma pessoa anônima, sem notoriedade, portanto, que teria agido de forma a colocar em perigo a segurança do Estado, por exemplo, subtraindo documentos secretos internos a um órgão estatal, caso em que deveria prevalecer a liberdade de informação; e, em um último caso d) seria divulgado que um funcionário público no exercício da função teria cometido ilegalidades, mas a notícia teria sido dada com uso de vocábulos ofensivos, injuriosos, lesando de modo extremamente grave sua imagem e projeção pública, o que levaria à prevalência da proteção à honra. $\mathrm{O}$ acréscimo desse passo na matriz deliberativa resultaria nas seguintes informações: 


\begin{tabular}{|l|l|l|l|}
\hline $\begin{array}{l}\text { MATRIZ } \\
\text { DELIBERATIVA }\end{array}$ & $\begin{array}{l}\text { Informação } \\
\text { (opinião pública) }\end{array}$ & $\begin{array}{l}\text { Honra } \\
\text { (dignidade) }\end{array}$ & Solução \\
\hline Caso em conflito & $\begin{array}{l}\text { Alternativa A } \\
\text { Alternativa B }\end{array}$ & $\begin{array}{l}\text { Alternativa B } \\
\text { Alternativa A }\end{array}$ & $?$ \\
\hline $\begin{array}{l}\text { Caso Paradigmático } \\
\text { A }\end{array}$ & $\begin{array}{l}\text { Alternativa C } \\
\text { Alternativa D }\end{array}$ & $\begin{array}{l}\text { Alternativa D } \\
\text { Alternativa C }\end{array}$ & $\begin{array}{l}\text { Alternativa C } \\
\text { Alternativa D }\end{array}$ \\
\hline Caso Paradigmático & $\begin{array}{l}\text { Alternativa E } \\
\text { B }\end{array}$ & Alternativa F & Alternativa F \\
Caso Paradigmático F & Alternativa G & Alternativa E & Alternativa E \\
C & Alternativa H & Alternativa G & $\begin{array}{l}\text { Alternativa G } \\
\text { Alternativa H }\end{array}$ \\
\hline $\begin{array}{l}\text { Caso Paradigmático } \\
\text { D }\end{array}$ & $\begin{array}{l}\text { Alternativa I } \\
\text { Alternativa J }\end{array}$ & Alternativa J & $\begin{array}{l}\text { Alternativa J } \\
\text { Alternativa I }\end{array}$ \\
\hline
\end{tabular}

Assim, conforme acima referido, no caso paradigmático A, com a prevalência da opinião pública e, logo, da informação, suas alternativas prevalecem, determinadando a razão prevalecente aplicável. No caso paradigmático B, o princípio prevalecente seria a honra e, portanto, as alternativas para tutela da honra prevaleceriam. No caso paradigmático $\mathrm{C}$, como visto, haveria prevalência do direito à informação e, portanto, das razões por ela determinadas. Finalmente, no caso paradigmático D, as alternativas predominantes seriam as determinadas pela honra, por ser esse o direito prevalecente.

$\mathrm{Na}$ quarta etapa do processo deliberativo, tendo-se em vista os casos paradigmáticos acima elencados, o procedimento seguinte seria de elaboração das hipóteses sobre como as circunstâncias ou condições que incidem na importância de cada razão em conflito determinam a solução do mesmo, considerando-se como hipótese mais satisfatória a que abarque o maior número de casos paradigmáticos. Desse modo, as razões do caso delimitariam as circunstâncias consideradas como relevantes, as quais, no caso em questão, seriam apenas as propriedades que tenham ou possam ter incidência na formação da opinião pública e sobre a honra.

Disso seria extraída uma primeira hipótese de que nos casos em que a pessoa sobre quem se fala na notícia seja pública (ao que se denomina 'p'), prevalece a liberdade de informação sobre o direito à honra, o que seria satisfatório para resolver o caso $\mathrm{A}$, mas não o caso $\mathrm{B}$ em que existe relevância pública da pessoa, mas prevalece o direito à honra. $\mathrm{O}$ caso $\mathrm{C}$ 
demonstra que o anonimato da pessoa não repercutiria como condição necessária da prevalência da liberdade de informação e, por isso, a primeira hipótese se mostraria limitada.

Uma segunda hipótese seria de que o assunto fosse de relevância pública, podendo-se referir como 'q', dando-se, portanto, ênfase ao assunto e não à pessoa, embora esta possa implicar que o assunto a ela relativo seja de relevância pública. Esse critério seria compatível com o caso A e com o caso $\mathrm{C}$ e, indiretamente (falta de relevância pública do assunto), com o caso B, determinando-se que na inexistência de relevância pública de um assunto, prevaleceria o direito à honra, em detrimento da liberdade de informação. No entanto, não daria conta do caso $\mathrm{D}$, pois, neste caso, o assunto é de interesse público, mas não prevalece a liberdade de informação.

Uma hipótese para se explicar a solução deste caso poderia ser de que a importância do direito à honra, fundamentado na dignidade, baseia-se no grau de afetação da dignidade; e a importância da liberdade de informação pauta-se no grau de contribuição da notícia à formação de uma opinião pública livre.

Assim, quanto mais uma medida afete a dignidade, maior seria a importância do direito à honra e, no caso $\mathrm{D}$, a dignidade seria mais gravemente afetada mediante uso de expressões ofensivas que, além de atingirem a dignidade, seriam desnecessárias para a transmissão da informação.

O que levaria à formação da hipótese de que ao se utilizarem expressões vexatórias ou ofensivas (simbolizadas por ' $r$ '), prevaleceria o direito à honra, mesmo que a informação seja de relevância pública. De modo que para prevalecer o direito à liberdade é mister que haja como condições que o assunto seja de relevância pública e que não se usem expressões ofensivas $\left(\mathrm{q}^{\wedge} \neg \mathrm{r}\right)$. Após a elaboração e refinamento de todas as hipóteses, enseja-se a complementação conforme a seguinte matriz deliberativa:

\begin{tabular}{|c|c|c|c|}
\hline $\begin{array}{l}\text { MATRIZ } \\
\text { DELIBERATIVA }\end{array}$ & $\begin{array}{l}\text { Informação } \\
\text { (opinião pública) }\end{array}$ & $\begin{array}{l}\text { Honra } \\
\text { (dignidade) }\end{array}$ & Solução \\
\hline Caso em conflito & $\begin{array}{l}\text { Alternativa A } \\
\text { Alternativa B }\end{array}$ & $\begin{array}{l}\text { Alternativa B } \\
\text { Alternativa A }\end{array}$ & $?$ \\
\hline $\begin{array}{l}\text { Caso Paradigmático } \\
\text { A }\end{array}$ & $\begin{array}{l}\text { Alternativa C } \\
\text { Alternativa D }\end{array}$ & $\begin{array}{l}\text { Alternativa D } \\
\text { Alternativa C }\end{array}$ & $\begin{array}{l}\text { Alternativa C } \\
\text { Alternativa D }\end{array}$ \\
\hline $\begin{array}{l}\text { Caso Paradigmático } \\
\text { B }\end{array}$ & $\begin{array}{l}\text { Alternativa E } \\
\text { Alternativa F }\end{array}$ & $\begin{array}{l}\text { Alternativa } \mathrm{F} \\
\text { Alternativa } \mathrm{E}\end{array}$ & $\begin{array}{l}\text { Alternativa F } \\
\text { Alternativa E }\end{array}$ \\
\hline
\end{tabular}




\begin{tabular}{|c|c|c|c|}
\hline $\begin{array}{l}\text { Caso Paradigmático } \\
\text { C }\end{array}$ & $\begin{array}{l}\text { Alternativa } \mathrm{G} \\
\text { Alternativa } \mathrm{H}\end{array}$ & $\begin{array}{l}\text { Alternativa } \mathrm{H} \\
\text { Alternativa } \mathrm{G}\end{array}$ & $\begin{array}{l}\text { Alternativa } \mathrm{G} \\
\text { Alternativa } \mathrm{H}\end{array}$ \\
\hline $\begin{array}{l}\text { Caso Paradigmático } \\
\text { D }\end{array}$ & $\begin{array}{l}\text { Alternativa I } \\
\text { Alternativa } \mathrm{J}\end{array}$ & $\begin{array}{l}\text { Alternativa J } \\
\text { Alternativa I }\end{array}$ & $\begin{array}{l}\text { Alternativa J } \\
\text { Alternativa I }\end{array}$ \\
\hline $\begin{array}{l}\text { Hipótese Definitiva } \\
\text { Casos A, C }\end{array}$ & $\begin{array}{l}\text { Prevalece C, G sob } \\
\text { 'q } \wedge^{\wedge} \neg \mathrm{r} \text { ' }\end{array}$ & $\begin{array}{l}\text { Prevalece D, H sob } \\
\text { 'q } \wedge^{\wedge} \neg \mathrm{r} \text { ' }\end{array}$ & $\begin{array}{l}\text { Informação prevalece } \\
\text { sobre a honra na } \\
\text { condição ' } \mathrm{q}^{\wedge} \neg \mathrm{r} \text { ' }\end{array}$ \\
\hline $\begin{array}{l}\text { Hipótese Definitiva } \\
\text { Caso B }\end{array}$ & $\begin{array}{l}\text { Prevalece E sob } \\
\text { ' } \neg q^{\wedge} \neg r '\end{array}$ & $\begin{array}{l}\text { Prevalece E sob } \\
\text { ' } \neg q^{\wedge} \neg r '\end{array}$ & $\begin{array}{l}\text { Honra prevalece } \\
\text { sobre informação sob } \\
\text { ' } \neg q^{\wedge} \neg \text { ' }\end{array}$ \\
\hline $\begin{array}{l}\text { Hipótese Definitiva } \\
\text { Caso D }\end{array}$ & $\begin{array}{l}\text { Prevalece I sob } \\
\text { 'q^^r' }\end{array}$ & $\begin{array}{l}\text { Prevalece J sob } \\
' \mathrm{q}^{\wedge} \mathrm{r} \text { ' }\end{array}$ & $\begin{array}{l}\text { Honra prevalece } \\
\text { sobre informação sob } \\
\text { 'q^ r' }\end{array}$ \\
\hline
\end{tabular}

Nesse caso, fica desconsiderada a situação em que a informação não tenha relevância pública e sejam usadas expressões ofensivas, situação que poderia ser resolvida pela hipótese de prevalência do direito à honra. Isso considerado, na quinta etapa do processo deliberativo se aplicaria a melhor hipótese ao caso que se deve resolver, considerando-se presentes ou ausentes as circunstâncias 'q' e 'r', respectivamente, relevância pública da informação e utilização de expressões ofensivas.

Supondo-se que, no caso em questão, a informação tenha relevância pública e não se usem expressões ofensivas, a solução seria a prevalência da liberdade de expressão consoante a matriz deliberativa a seguir:

\begin{tabular}{|l|l|l|l|}
\hline $\begin{array}{l}\text { MATRIZ } \\
\text { DELIBERATIVA }\end{array}$ & $\begin{array}{l}\text { Informação } \\
\text { (opinião pública) }\end{array}$ & $\begin{array}{l}\text { Honra } \\
\text { (dignidade) }\end{array}$ & Solução \\
\hline $\begin{array}{l}\text { Caso em conflito } \\
\left(\mathbf{q}^{\wedge} \neg \mathbf{r}\right)\end{array}$ & $\begin{array}{l}\text { Alternativa A } \\
\text { Alternativa B }\end{array}$ & $\begin{array}{l}\text { Alternativa B } \\
\text { Alternativa A }\end{array}$ & $\begin{array}{l}\text { Alternativa A } \\
\text { Alternativa B }\end{array}$ \\
\hline
\end{tabular}

Na solução de casos em que há conflitos de princípios, para David Zorrilla, a vantagem desse modelo coerentista seria de que, diferentemente de uma referência tal como a de Alexy de forma genércia a "circunstâncias do caso", sem oferecer parâmetros para a escolha de propriedades, o modelo de Susan Hurley permitiria a determinação das 
propriedades relevantes admissíveis, pela incidência das razões que fundamnetam as distintas soluções do caso, de modo a serem propriedades relevantes apenas aquelas que incidam na satisfação ou que sejam óbice à satisfação das razões em conflito.

Diante disso, o modelo de Susan Hurley permitiria falar em soluções corretas mediante o cumprimento dos seguintes requisitos: acordo sobre as razões subjacentes em conflito; acordo sobre a solução dos casos paradigmáticos, o que seria até mesmo uma redundância, dado que os casos paradigmáticos são os que têm solução consensualmente aceita; e, por fim, que exista acordo sobre a medida como certas circunstâncias empíricas ou não valorativas incidem na satisfação das razões subjacentes ${ }^{202}$.

No entanto, do exposto, nota-se a dificuldade de se aplicar o procedimento proposto por Hurley e o alto risco de equivocidade, pelo risco de se deixar de considerar algum caso paradigmático que, eventualmente, teria implicação sobre o caso em questão e, especialmente, que pudesse modificar o resultado, caso tivesse sido considerado.

Ademais, o levantamento de hipóteses não necessariamente implica a correção da hipótese tomada e, logo, considerada uma hipótese explicativa incorreta - até porque entram em jogo inferências abdutivas, como no item seguinte (2.2.5) se falará -, a determinação das propriedades relevantes também estaria comprometida e a própria solução do caso.

\subsubsection{Modelo inferencial}

No modelo inferencial, a coerência é formada como um procedimento de inferência abdutiva. O modelo de Susan Hurley pode ser pensado como inferências de princípios a partir de propriedades de precedentes. No livro Positivismo Jurídico Lógico-Inclusivo ${ }^{203}$, Juliano Maranhão constrói um modelo inferencial tomando princípios como inferências abdutivas a partir de propriedades de regras postas. O esforço está em conciliar a ponderação de princípios à vinculação à lei. Ou seja, a coerência asseguraria a justificação da decisão judicial - o que não significa e mesmo não implica sua correção, com o que o autor não se compromete $^{204}$ - à luz de princípios, tendo em vista o material autoritativo, o ordenamento

\footnotetext{
202 ZORRILLA, David Martínez. Conflictos Constitucionales, Ponderación e Indeterminación Normativa. Tesis Doctoral. Universidad Pompeu Fabra, Barcelona, 2004, p. 300.

203 MARANHÃO, Juliano Souza de Albuquerque. Positivismo Jurídico Lógico-Inclusivo. São Paulo: Marcial Pons, 2012.

${ }^{204}$ O autor deixa claro: "Não é minha preocupação uma justificação da coerência como apta a proporcionar correção, mas somente descrever o tipo de inferência envolvida em justificações a partir de normas, na medida em que essas são tomadas como resultado de uma ação racional”. MARANHÃ̃, Juliano Souza de Albuquerque.
} 
jurídico, uma vez que os princípios são tomados como a melhor explicação possível para as regras aplicáveis ao caso.

Assim, há certa semelhança entre a proposta do autor e a de Susan Hurley, porém, distintamente desta, cuja teoria coerentista volta-se a sistemas jurídicos de common law, tendo por bases referenciais os precedentes judiciais considerados como casos paradigmáticos, Juliano Maranhão ajusta essa perspectiva a sistemas de civil law, em que a lei é a fonte autoritativa primacial, que inclusive garante juridicidade aos princípios invocados nas decisões judiciais como razões decisórias.

Nesse sentido, sua proposta também leva a uma aparente similitude à proposta do direito como integridade de Ronald Dworkin, em que este autor reconhece os princípios jurídicos subjacentes às regras como razões justificativas para elas. No entanto, a semelhança é apenas aparente, porque há entre os autores uma distinção substancial e é, até mesmo, em uma busca de contraponto à teoria antipositivista que Dworkin que Maranhão postula o inclusivismo lógico.

Se a teoria coerentista de Dworkin leva à sua postulação antipositivista de que o Direito está justificado por princípios subjacentes às regras e que tais princípios valem por seu conteúdo moral, Maranhão situa-se em posição diametralmente oposta: princípios $^{205}$ valem porque explicam normas jurídicas, independentemente de seu conteúdo, ou seja, basta que expliquem o ordenamento como um todo coerente.

Esses princípios seriam derivados por inferências lógicas a partir das regras dotadas de autoridade que os endossem. Embora não houvesse uma neutralidade valorativa - dada a reconstrução interpretativa do ordenamento - haveria uma neutralidade moral ${ }^{206}$. Vale esclarecer que o autor refere-se a ordenamento jurídico ${ }^{207}$ :

[...] para designar aquele material pré-interpretativo, que não se reduz a textos promulgados, mas consiste no conjunto daqueles sentidos

Inclusivismo Lógico: uma contribuição à metodologia jurídica. Tese de livre-docência, Departamento de Filosofia e Teoria Geral do Direito, Universidade de São Paulo, São Paulo, 2010, p. 175.

${ }^{205}$ Maranhão não deixa de considerar a equivocidade ou multiplicidade na própria definição de princípio, como já exposto na nota 53. Vide: MARANHÃO, Juliano Souza de Albuquerque. Inclusivismo Lógico: uma contribuição à metodologia jurídica. Tese de livre-docência, Departamento de Filosofia e Teoria Geral do Direito, Universidade de São Paulo, São Paulo, 2010, p. 75 et seq.

${ }^{206}$ Contudo, Maranhão esclarece: "Não esperem uma demonstração direta de que seria possível a neutralidade moral da ciência jurídica, apenas faço uma objeção a uma determinada crítica que pretendeu mostrar sua impossibilidade". MARANHÃO, Juliano Souza de Albuquerque. Inclusivismo Lógico: uma contribuição à metodologia jurídica. Tese de livre-docência, Departamento de Filosofia e Teoria Geral do Direito, Universidade de São Paulo, São Paulo, 2010, p. 12.

207 MARANHÃO, Juliano Souza de Albuquerque. Inclusivismo Lógico: uma contribuição à metodologia jurídica. Tese de livre-docência, Departamento de Filosofia e Teoria Geral do Direito, Universidade de São Paulo, São Paulo, 2010, p. 115-116. 
preliminarmente atribuídos aos textos dotados de autoridade, com base nas convenções linguísticas ordinárias (não técnicas) sobre os termos empregados nas formulações normativas. [destaque no autor]

No entanto, sua concepção de Direito é de que se trata de “... um conjunto de sistemas normativos decorrentes de reconstruções interpretativas do ordenamento que incluem normas e princípios como razões jurídicas vinculantes" ${ }^{208}$. Ou seja, há uma reconstrução da base original por meio de inferências, sejam dedutivas ou e, em especial, abdutivas.

No que diz respeito a essas, Maranhão parte da postulação de Charles Sanders Peirce, tributário do legado aristotélico, em sua distinção dos três tipos de raciocínio: dedutivo, indutivo e abdutivo. $\mathrm{Na}$ dedução, a conclusão decorre logicamente das premissas, não introduzindo novo vocabulário, seguindo a formulação elementar: "Todo ser humano é mortal”; "João é um ser humano", logo, "João é mortal”.

A indução, como forma de inferência ampliativa adiciona informação pela generalização de observações partindo da conclusão: por exemplo, "esses feijões são desse saco"; "esses feijões são brancos"; logo, "todos os feijões desse saco são brancos". O que denota uma potencial refutabilidade no caso da indução, apesar da probabilidade de acerto.

Já a inferência abdutiva, que segundo Peirce é o único raciocínio que seria capaz de formar uma nova ideia ou uma hipótese explanatória, trata-se da inferência do caso a partir da regra e do resultado. Assim, se a regra é "Todos os feijões desse saco são brancos"; e "Esses feijões são brancos", infere-se que "Esses feijões são desse saco". Nesse caso, também se nota sua derrotabilidade ${ }^{209}$.

Consoante sintetiza Pablo Bonorino, as características definitórias da abdução são de que: trata-se do processo de formar uma hipótese explicativa; é a única operação lógica que introduz novo conhecimento; parte de fatos presumindo-se que possam ser explicados por uma teoria; e, finalmente, consiste na busca dessa teoria que é sugerida pela consideração dos fatos $^{210}$. Assim, ante um fenômeno surpreendente, busca-se uma teoria que o explique, ou seja, que o torne necessário consoante o seguinte modelo de inferência abdutiva ${ }^{211}$ :

\footnotetext{
${ }^{208}$ MARANHÃO, Juliano Souza de Albuquerque. Inclusivismo Lógico: uma contribuição à metodologia jurídica. Tese de livre-docência, Departamento de Filosofia e Teoria Geral do Direito, Universidade de São Paulo, São Paulo, 2010, p. 79.

${ }^{209}$ Peirce explica que "[...] a Abdução simplesmente sugere que alguma coisa pode ser. Sua única justificativa é que a partir de suas sugestões a dedução pode extrair uma predição que pode ser verificada por indução, e isso, se é que nos é dado aprender algo ou compreender os fenômenos, deve ser realizado através da abdução". [destaque do autor] PEIRCE, Charles Sanders. Semiótica. São Paulo: Perspectiva, 1977, p. 220.

${ }^{210}$ BONORINO, Pablo Raúl. Sobre la abducción. Doxa, a. 14, p. 207-241, 1993, p. 218.

${ }^{211}$ Esse modelo inferencial é apresentado na obra Collected Papers e a tradução conforme aqui expressa consta em: CHIBENI, Silvio Seno. A inferência Abdutiva e o Realismo Científico. Cadernos de História e Filosofia da Ciência, série 3, 6 (1), p. 45-73, 1996.
} 
O fato surpreendente $\mathrm{C}$ é observado.

Se A fosse verdadeiro, $\mathrm{C}$ seria um fato natural.

Logo, há razão para suspeitar que A seja verdade.

Considera-se como fenômeno surpreendente aquele caracterizado pela novidade em relação a fatos ou regras conhecidos ou por sua anomalia, destoando, pois, do conhecido e, portanto, exigindo uma explicação. No entanto, como salienta Atocha Aliseda, a noção de surpresa é relativa, já que um fato é surpreendente apenas em relação a alguma teoria de base que proveja expectativas, ou seja, tendo-se em vista um contexto em que haja crenças estabelecidas. A autora ainda acrescenta que a abdução não se trata de padrão de inferência lógica $^{212-213}$, já que opera retroativamente, enquanto que o padrão inferencial opera prospectivamente e, ademais, a abdução está sujeita à revisão mediante novas evidências, o que a caracteriza como um padrão não-monotônico.

Assim, da perspectiva lógica da inferência dedutiva, típica do raciocínio matemático, a característica do raciocínio é certeza e monotonicidade, sendo a relação entre as premissas e a conclusão necessária e não derrotável. A abdução, apesar da falta de completa certeza e monotonicidade, não significa que não tenha propriedades lógicas próprias pelo fato de ser uma inferência ampliativa, tal como a indução também o é ${ }^{214-215}$.

\footnotetext{
${ }^{212}$ Juliano Maranhão também questiona a adequação do termo inferência para o raciocínio abdutivo, uma vez que a sua "conclusão não tem suporte nas premissas, apenas se sabe que, se fosse verdadeira, então estaríamos garantidos em deduzir a observação" (MARANHÃO, Juliano Souza de Albuquerque. Inclusivismo Lógico: uma contribuição à metodologia jurídica. Tese de livre-docência, Departamento de Filosofia e Teoria Geral do Direito, Universidade de São Paulo, São Paulo, 2010, p. 81). Embora o uso do termo se justificasse pela preocupação filosófica de Peirce em estender a lógica e as categorias kantianas de forma a construir uma lógica de juízos sintéticos como um método de aquisição. Peirce busca sustentar o caráter lógico-inferencial da abdução no ponto 188 do quinto volume de Collected Papers (CP, 5.188): "For the question is whether that which really is an abductive result can contain elements foreign to its premisses. It must be remembered that abduction, although it is very little hampered by logical rules, nevertheless is logical inference, asserting its conclusion only problematically or conjecturally, it is true, but nevertheless having a perfectly definite logical form". HARTSHORNE, Charles, WEISS, Paul, BURKS, Arthur (Orgs.). The Collected Papers of Charles Sanders Peirce. Cambridge, MA: Harvard University Press, 1931-35 e 1958. 8 v.

${ }^{213}$ Paavola e Hakkarainen expõem que até mesmo Peirce considerava a abdução como apenas uma "forma fraca" de inferência, no sentido de que fornece respostas apenas plausíveis ou possíveis e não necessariamente certas. $\mathrm{O}$ que não significa, todavia, que seja um processo meramente aleatório, até porque a pura sorte não permitiria tão rápido desenvolvimento da cultura humana como a história atesta. Ademais, entre diversas hipóteses possíveis, seria necessário reunir conjeturas de forma plausível e coerente, buscando a que melhor explicasse o fenômeno. PAAVOLA, Sami; HAKKARAINEN, Kai. Three Abductive Solutions to the Meno Paradox - with instinct, inference, and distributed cognition. Studies in Philosophy and Education, a. 24, p. 235-253, 2005, p. 237 e 249. No mesmo sentido: SANTAELLA, Lucia. O método anticartesiano de C. S. Peirce. São Paulo: UNESP, 2004, p. 101.

${ }^{214}$ ALISEDA, Atocha. Abductive Reasoning - Logical Investigations into Discovery and Explanation. Dordrecht: Springer, 2006, passim.

${ }^{215}$ São consideradas inferências ampliativas, pois inserem novo vocabulário - apesar de Peirce considerar apenas a abdução como meio de criação de informações -. A abdução, por meio da geração de hipótese explicativa, e a indução pela formulação de uma regra a partir de um caso e o resultado dele obtido. Quanto ao a esse caráter ampliativo: NIINILUOTO, Ilkka. Defending Abduction. Philosophy of Science, v. 66, p. S436-S451, 1999.
} 
Como aponta Maranhão, hodiernamente tornou-se padrão estudar a inferência abdutiva na forma de "inferência à melhor explicação possível”, podendo-se distinguir entre dois momentos ou etapas nessa inferência: ante um evento surpreendente ${ }^{216}$, há uma primeira etapa de levantamento de hipóteses explicativas e a segunda envolveria um método de prova em que as hipóteses são contrastadas com observações.

Por tal razão, embora a possibilidade de levantamento de hipóteses explicativas pudesse ser inumerável, há uma estrutura de referência baseada em experiências colaterais, ou seja, já vivenciadas pelo intérprete, que restringe a busca pela solução para o fato surpreendente, de modo que a escolha de hipóteses explicativas não se trata de um processo simplesmente aleatório $^{217}$, pois apenas se admitem como hipóteses aquelas que tenham potencial de explicar os fatos surpreendentes.

Assim, a chuva é uma hipótese para a grama molhada apenas porque se sabe que tem o poder de explicar esse fenômeno, embora a causa real pudesse ter sido não a chuva, nem vazamento ou tampouco as plantas regradas, mas simplesmente o sereno, esta também uma hipótese, porque explica o fenômeno observado ${ }^{218-219}$.

\footnotetext{
216 "Essa surpresa pode ser de dois tipos: uma novidade, que não é explicada pela base; ou uma anormalidade, quando a base deriva algo que é, em algum sentido, incompatível com a evidência". MARANHÃO, Juliano Souza de Albuquerque. Inclusivismo Lógico: uma contribuição à metodologia jurídica. Tese de livre-docência, Departamento de Filosofia e Teoria Geral do Direito, Universidade de São Paulo, São Paulo, 2010, p. 84.

${ }^{217}$ Segundo Atocha Aliseda, o processo abdutivo não é nem totalmente racional, nem totalmente cego. ALISEDA, Atocha. Logic in Scientific Discovery. Foundations of Science, a. 9, p. 339-363, 2004, p. 344.

${ }^{218}$ O processo de seleção de hipóteses começa de maneira intuitiva conforme Peirce (CP 7.220): "These are of two kinds, the purely instinctive and the reasoned. In regard to instinctive considerations, I have already pointed out that it is a primary hypothesis underlying all abduction that the human mind is akin to the truth in the sense that in a finite number of guesses it will light upon the correct hypothesis. Now inductive experience supports that hypothesis in a remarkable measure". HARTSHORNE, Charles, WEISS, Paul, BURKS, Arthur (Orgs.). HARTSHORNE, Charles, WEISS, Paul, BURKS, Arthur (Orgs.). The Collected Papers of Charles Sanders Peirce. Cambridge, MA: Harvard University Press, $1931-35$ e 1958. 8 v. De acordo com Peirce, três considerações deveriam determinar a escolha da uma hipótese: um primeiro lugar, sua capacidade de ser passível de teste experimental, já que, levantada uma hipótese possível, sua consequência é traçada por dedução e tais consequências são comparadas com resultados testados por indução; no caso de a hipótese levantada ser refutada, ela é descartada e outra hipótese é levantada e testada - o que remete ao caráter inferencial da abdução, já que, se o juízo perceptivo teria natureza instintiva, o juízo abdutivo que leva à hipótese a ser testada, se enquadraria no modelo inferencial. Em segundo lugar, a hipótese deve ter o poder de explicar os fatos surpreendentes; portanto, baixas temperaturas, por exemplo, não teriam o condão de explicar o derretimento do gelo, mas poderiam explicar uma "queimadura" epidérmica, tanto quanto altas temperaturas. Finalmente, devese relevar a economia, escolhendo-se a hipótese mais econômica, o que depende de seu custo, do valor em si da proposta e de seu efeito sobre outras explanações.

${ }^{219}$ Quanto a esses critérios de Peirce, Atocha Aliseda considera que “... the motivation for the economic criterion is twofold: a response to the practical problem of having innumerable explanatory hypotheses to test, as well as the need for a criterion to select the best explanation amongst the testable ones... Testability as understood by Peirce is an extra-logical empirical criterion, while economy concerns the selection of explanations, which we already put aside as a further stage of abduction requiring a separate study". ALISEDA, Atocha. Abductive Reasoning - Logical Investigations into Discovery and Explanation. Dordrecht: Springer, 2006, p. 37.
} 
Para o problema de se julgar a melhor hipótese, ou seja, escolher dentre as hipóteses levantadas a que seja a melhor explicação possível, Gilbert Harman entende que a solução seria dada, presumivelmente, mediante a escolha da que fosse a hipótese mais simples, mais plausível, mais explicativa, bem como a menos específica $(a d h o c)^{220}$. No entanto, esses quesitos podem conflitar e não há padrões objetivos, senão consensuais para se aferir esses caracteres. Para Paul Thagard, também a simplicidade seria um critério para escolha da melhor hipótese, tanto quanto a consiliência ${ }^{221}$ e a analogia. Juliano Maranhão sintetiza ${ }^{222}$ :

[...] hipóteses preferidas são aquelas que melhor se ajustam ao conjunto: (i) confirmam as evidências consideradas essenciais (poder explicativo e consistência com evidências), não desafiam, ou exigem pouco ajuste do conhecimento de base (conservadorismo), não assumem condições em demasia (simplicidade), integram-se bem a hipóteses já assumidas ou permitem reduzi-las (unificação), e são precisas em explicar os dados selecionados e não um conjunto maior de dados irrelevantes (precisão). Essas "virtudes" são típicas de epistemologias baseadas em avaliação de coerência de teorias, de forma que a inferência abdutiva, nesse formato, pressupõe essa avaliação.

A importância da abdução na proposta coerentista de Maranhão é que essa inferência permite, a partir de um conjunto de atos normativos (leis, jurisprudência), alcançar o princípio que poderia explicar de modo mais coerente a razão pela qual aquele conjunto de normas foi criado com aquele conteúdo e com aquela formulação normativa ${ }^{223}$, tendo-se em vista a presunção, embora contrafática, de racionalidade em razão de uma vontade unitária e racional por detrás dos textos legais ${ }^{224}$.

\footnotetext{
${ }^{220}$ HARMAN, Gilbert H. The Inference to the Best Explanation. The Philosophical Review, v. 74, n. 1, p. 88-95, jan. 1965 , p. 89.

${ }^{221}$ A consiliência diz respeito ao poder explicativo da teoria e é propriedade relativa: uma teoria é mais ou menos consiliente em relação a outra. "Roughly, a theory is said to be consilient if it explains at least two classes of facts. Then one theory is more consilient than another if it explains more classes of facts than the other does". THAGARD, Paul R. The Best Explanation: Criteria for Theory Choice. The Journal of Philosophy, v. 75, n. 2, p. 76-92, feb. 1978, p. 79.

222 MARANHÃO, Juliano Souza de Albuquerque. Inclusivismo Lógico: uma contribuição à metodologia jurídica. Tese de livre-docência, Departamento de Filosofia e Teoria Geral do Direito, Universidade de São Paulo, São Paulo, 2010, p. 85.

${ }^{223}$ MARANHÃO, Juliano Souza de Albuquerque. Inclusivismo Lógico: uma contribuição à metodologia jurídica. Tese de livre-docência, Departamento de Filosofia e Teoria Geral do Direito, Universidade de São Paulo, São Paulo, 2010, p. 86.

${ }^{224}$ Maranhão parte de alguns pressupostos contrafáticos: "Dentre seus atributos, estão os seguintes postulados de competência, desenvolvidos pela dogmática alemã do séc. XIX: a) o legislador não cria normas impossíveis de serem executadas, daí por que não se pode desejar que alguém realize e deixe de realizar o mesmo ato; b) o legislador não cria normas sem algum propósito c) as condutas exigidas ou permitidas nas normas são aptas a levar os sujeitos normativos à consecução dos propósitos da regulação (coerência entre meios e fins); d) a vontade do legislador é unitária, de forma que as regras estão sistematicamente relacionadas; e) a vontade do legislador é completa, no sentido de que soluciona todos os casos por ele reputados como relevantes; f) o legislador é rigorosamente preciso e não cria normas inócuas ou redundantes. Esses postulados restringem
} 
No âmbito jurídico, as hipóteses selecionadas para explicar o material jurídico autoritativo também são restringidas, por ser necessária sua compatibilidade com o conteúdo do conjunto de normas consideradas válidas. O autor exemplifica que a justificativa para a imposição de limites de velocidade, e suas diferenciações em vias distintas, é o conhecimento pericial de que determinadas velocidades podem ser seguras no sentido de que, em caso de acidentes, não haveria potencial risco de morte. Portanto, a vida é uma razão justificativa do conteúdo dessas normas ${ }^{225}$ :

Com isso, há uma relação de transmissão de razões entre as premissas e a conclusão de uma inferência abdutiva normativa. A conclusão, i.e. o princípio jurídico, é aceito como razão porque e na medida em que seja a melhor explicação para aquele conjunto de normas selecionado como relevante para a ação em questão.

E aqui fica clara a distinção ${ }^{226}$ entre a proposta de Maranhão e a de Dworkin, já que para o primeiro,

[...] princípios morais e de políticas públicas são jurídicos porque e na medida em que proporcionem uma justificação coerente das normas jurídicas válidas (e não o contrário, i.e. tais regras são válidas por conta de seu mérito moral ou porque aderem a um conjunto de valores morais). Ou seja, princípios jurídicos são razões jurídicas, pois estão implícitos no conteúdo conceitual das regras quando tomadas como um ato racional em uma determinada construção interpretativa. São o resultado de inferências abdutivas a partir do conteúdo dessas regras.

Isso porque os princípios, "ao explicarem as regras técnicas presentes no sistema normativo resultante da interpretação racional, integram-se a ele... também constituem razões para a ação. São parâmetros normativos"227 em razão de sua capacidade em explicar

possíveis atribuições de sentido ou propósito ao legislador que firam alguma dessas competências. MARANHÃO, Juliano Souza de Albuquerque. Inclusivismo Lógico: uma contribuição à metodologia jurídica. Tese de livre-docência, Departamento de Filosofia e Teoria Geral do Direito, Universidade de São Paulo, São Paulo, 2010, p. 87-88.

${ }^{225}$ MARANHÃO, Juliano Souza de Albuquerque. Inclusivismo Lógico: uma contribuição à metodologia jurídica. Tese de livre-docência, Departamento de Filosofia e Teoria Geral do Direito, Universidade de São Paulo, São Paulo, 2010, p. 88

226 MARANHÃO, Juliano Souza de Albuquerque. Inclusivismo Lógico: uma contribuição à metodologia jurídica. Tese de livre-docência, Departamento de Filosofia e Teoria Geral do Direito, Universidade de São Paulo, São Paulo, 2010, p. 130.

227 MARANHÃO, Juliano Souza de Albuquerque. Inclusivismo Lógico: uma contribuição à metodologia jurídica. Tese de livre-docência, Departamento de Filosofia e Teoria Geral do Direito, Universidade de São Paulo, São Paulo, 2010, p. 157. 
determinado conteúdo como resultado de um ato racional. Assim, por um lado, os princípios justificam o conteúdo das regras e, por outro, recebem destas sua juridicidade ${ }^{228}$.

Mas, como resultado de uma inferência abdutiva, a interpretação do ordenamento jurídico é defensável e "o material pré-interpretativo, o ordenamento, pode gerar pacotes locais de soluções coerentes e concorrentes entre si" ${ }^{229}$. Daí se vê que também de modo diferente de Dworkin, o modelo coerentista inferencial empregado por Maranhão é local e, distintamente daquele, não vislumbra uma única resposta correta, enquadrando sua tese na classe de "teorias racionalistas locais subdeterminadas", que é a classe de teorias coerentistas mais modesta, conforme a qual "o fechamento coerentista do ordenamento, além de local, é subdeterminado" dadas as diversas soluções possíveis. Esse modelo, contudo, seria consoante o autor ${ }^{230}$ um mecanismo para

[...] explicar o direito e, em particular, o recurso pelos tribunais a decisões com base em princípios morais e de políticas públicas considerados vinculantes, sem recurso a uma justificação moral do conteúdo desses parâmetros normativos. Trata-se de considerar apenas que a sua força vinculante decorre do fato de serem derivados de razões dadas por normas pertencentes ao ordenamento jurídico.

Com isso, essa proposta coerentista permite a conciliação entre a ponderação de princípios e a vinculação à lei, uma vez que a "proposta do 'inclusivismo lógico' mantém a preponderância de materiais autoritativos de base e busca à luz de princípios dar o fechamento coerentista a tais materiais" ${ }^{231}$. Exigindo-se fidelidade à base, ainda que admitidas eventuais alterações com o intuito justamente de dar-lhe maior coerência ${ }^{232}$.

\footnotetext{
${ }^{228}$ Conforme o próprio autor, "Tal questão, para esta tese, é ainda mais grave e ganha uma dimensão conceitual, pois aqui defendemos que os princípios morais ou políticos ganham juridicidade na extensão de sua capacidade em se firmar como a melhor explicação para aquele conteúdo presente na norma, ou seja, por serem inferidos por abdução do conteúdo das próprias normas". MARANHÃO, Juliano Souza de Albuquerque. Inclusivismo Lógico: uma contribuição à metodologia jurídica. Tese de livre-docência, Departamento de Filosofia e Teoria Geral do Direito, Universidade de São Paulo, São Paulo, 2010, p. 177.

${ }_{229}$ MARANHÃO, Juliano Souza de Albuquerque. Inclusivismo Lógico: uma contribuição à metodologia jurídica. Tese de livre-docência, Departamento de Filosofia e Teoria Geral do Direito, Universidade de São Paulo, São Paulo, 2010, p. 195.

${ }^{230}$ MARANHÃO, Juliano Souza de Albuquerque. Inclusivismo Lógico: uma contribuição à metodologia jurídica. Tese de livre-docência, Departamento de Filosofia e Teoria Geral do Direito, Universidade de São Paulo, São Paulo, 2010, p. 196.

${ }^{231}$ MARANHÃO, Juliano Souza de Albuquerque. Inclusivismo Lógico: uma contribuição à metodologia jurídica. Tese de livre-docência, Departamento de Filosofia e Teoria Geral do Direito, Universidade de São Paulo, São Paulo, 2010, p. 203.

232 "De manera que lo que defiendo es una especie de fidelidad a la base original de reglas establecidas. Aún cuando admito que la identificación de esta base de por sí implica operaciones de cambio y argumentación sobre la coherencia, una vez que la base es establecida, sólo muy pocas modificaciones son aceptadas y están justificadas, si están de acuerdo con principios reflejados por la base misma". MARANHÃO, Juliano Souza de
} 
Para ficar mais claro de que maneira Maranhão aplica as inferências abdutivas no ordenamento jurídico pátrio permitindo o fechamento coerentista, tendo-se em vista princípios jurídicos explicativos do conteúdo das normas, é relevante citar o exemplo desenvolvido pelo próprio autor, o que servirá, inclusive, de base para um dos casos trabalhados no capítulo seguinte, ao se tratar do caso de aborto de fetos anencéfalos.

Maranhão refere-se ao Art. 124 do Código Penal (CP) brasileiro segundo o qual $o$ aborto é proibido. Já o Art. 128 do mesmo diploma estabelece duas causas de permissão, uma no inciso primeiro, quando não houver outro meio de salvar a vida da gestante, portanto, havendo risco de morte desta; e outro no inciso segundo, caso de gravidez resultante de estupro em que haja consentimento da gestante ou de seu representante legal para o aborto.

Do que se nota que o Art. 124 do $\mathrm{CP}$ determina a proibição de aborto ( $O \sim a$ : obrigatório não abortar), enquanto o Art. 128 do $\mathrm{CP}$ estabelece casos em que é permitido abortar $(P a)$, evidenciando-se a inconsistência entre esses casos, embora sanável por mecanismos hermenêuticos. Então, o autor extrai desse material pré-interpretativo a seguinte reformulação indicada pelo asterisco: Art. 124* "o aborto é proibido se não for feito por médico ou, o sendo, se a gravidez não for resultado de estupro e não houver risco de vida da gestante”.

Ao conjunto original, Maranhão chama de $\mathrm{K}_{1}=\{124,128\}$. Para eliminar a inconsistência, ele aponta três possibilidades de reconstrução: dois casos por contração $\mathrm{K}_{2}=\{124\}$ e $\mathrm{K}_{3}=\{128\}$; e a terceira possibilidade, por refinamento $\mathrm{K}^{*}=\left\{124^{*}, 128\right\}$. Ele escolheu a última, embora houvesse as demais possibilidades, pois as duas anteriores implicariam um corte muito radical no sistema original.

Então, o autor cogita um segundo problema relativamente ao Art. 128 do CP questionando se os incisos I (aborto necessário ou terapêutico) e II (aborto sentimental) deveriam ser lidos conjuntamente ou disjuntivamente. Ou seja, se o aborto seria permitido se houvesse risco de morte da mãe $e$ se a gravidez fosse resultante de estupro tendo ela concordado com a realização do aborto $\left[\mathrm{Pa}\left(\mathrm{m}^{\wedge} \mathrm{e}^{\wedge} \mathrm{c}\right)\right]$ ou se o aborto seria permitido em um ou outro caso $\left[\mathrm{Pa}\left(\mathrm{m} v\left[\mathrm{e}^{\wedge} \mathrm{c}\right]\right]\right.$.

Do que concluiu que apenas a leitura disjuntiva seria coerente pois "já houve uma escolha dada pelo postulado de precisão do legislador racional: se fosse uma conjunção, ele não teria utilizado dois incisos", embora anuísse com o fato de "que, em diversos dispositivos, a separação pode ser usada para condições conjuntivas (é comum, inclusive, discussões 
doutrinárias em cima da leitura cumulativa ou disjuntiva de incisos de um dispositivo legal)", no entanto, o que tornaria a leitura disjuntiva indiscutível seria "a tentativa de compreensão da hierarquia dos princípios subjacentes que seria capaz de explicar uma ou outra leitura". Isso porque $^{233}$ :

O tema do aborto divide-se, em primeira linha, pela oposição entre o direito à vida do feto e a liberdade da mãe em dispor de seu corpo. $\mathrm{O}$ art. $124 \mathrm{faz}$ uma clara opção pela vida do feto. Seria difícil dar sentido ao seu conteúdo (proibição de aborto) se o feto não fosse sujeito de bem moral com direito à vida, conforme a escolha do legislador. A referência aos casos de estupro e risco de vida da mãe nos permite inferir outros valores de justificação, sem grande dificuldade: a dignidade da mulher e sua vida. Essa inferência ganha força quando se observa o poder explicativo desses princípios para outras normas correlatas do próprio código penal, como a punição ao estupro (art. 213 do Código Penal Brasileiro) e o conceito de "estado de necessidade" como excludente de ilicitude de um homicídio (art. 23 do Código Penal Brasileiro). A liberdade da mãe também recebe alusão expressa quando seu consentimento é exigido no caso de estupro.

Assim, conclui Maranhão: "É coerente explicar o conteúdo do art. 128 como um esforço do legislador racional em compatibilizar esses outros valores com a vida do feto"234, prevalecendo sobre esta a dignidade da mãe em caso de estupro, e prevalecendo a vida da mãe em caso de risco de morte desta.

Já no caso de uma leitura conjuntiva, somente a conjunção entre a vida da mãe e sua dignidade prevaleceriam sobre o direito à vida do nascituro e o autor questiona "Que sentido poderíamos construir sobre a diferença entre a vida de uma mãe e a vida de uma mãe estuprada? O fato de ter tido a sua honra violada lhe confere maior direito à vida?", o que ofenderia a igualdade e tornaria difícil uma explicação racional para essa escolha ${ }^{235}$.

\footnotetext{
233 MARANHÃO, Juliano Souza de Albuquerque. Inclusivismo Lógico: uma contribuição à metodologia jurídica. Tese de livre-docência, Departamento de Filosofia e Teoria Geral do Direito, Universidade de São Paulo, São Paulo, 2010, p. 110.

${ }^{234}$ MARANHÃO, Juliano Souza de Albuquerque. Inclusivismo Lógico: uma contribuição à metodologia jurídica. Tese de livre-docência, Departamento de Filosofia e Teoria Geral do Direito, Universidade de São Paulo, São Paulo, 2010, p. 110.

${ }^{235}$ Maranhão acrescenta: "A incoerência nessa leitura aumenta quando se procura justificar a norma relativa ao estado de necessidade como excludente de homicídio. Se em outros casos de estado de necessidade não se pune o homicídio e o aborto é uma forma de homicídio, porque aqui, e não ali, se exige que aquele que se encontra em estado gravemente periclitante tenha a sua dignidade de alguma forma violada?’. MARANHÃO, Juliano Souza de Albuquerque. Inclusivismo Lógico: uma contribuição à metodologia jurídica. Tese de livre-docência, Departamento de Filosofia e Teoria Geral do Direito, Universidade de São Paulo, São Paulo, 2010, p. 110.
} 
Concluída a reconstrução normativa por meio desse sistema normativo $\left(\mathrm{K}^{*}=\left\{124^{*}, 128\right\}\right)$, Maranhão ${ }^{236}$ aponta como fatores relevantes da norma para a ação de abortar (a) os seguintes: ser "realizado por médico" (m), "gravidez resultante de estupro" (e) e "risco de morte da mãe" (r); sendo $O, P$ os operadores deônticos, respectivamente, de obrigação e permissão. A partir dessas considerações o autor estabelece a seguinte formalização:

$$
\begin{aligned}
& 124=O \sim a \\
& 124^{*}=\sim(m(e \wedge r)) / O \sim a \\
& 128=m \wedge(e \vee r) / P a
\end{aligned}
$$

Ou seja, conforme o Art. 124 do CP é obrigatório não abortar ou proibido abortar; segundo o Art. 124*, é proibido abortar se não houver estupro e risco de morte da mãe, se houver, é permitido; e o Art. 128 do CP dispõe que é permitido abortar se houver risco de morte da mãe ou estupro e que o procedimento seja realizado por médico.

A partir disso, Maranhão, tendo como base a proposta de Alchourrón e Bulygin, constrói a seguinte matriz normativa com todas as soluções para os casos possíveis relevantes para essa regulação.

\begin{tabular}{|l|l|l|l|l|l|l|}
\hline & $\mathbf{M}$ & $\mathbf{E}$ & $\mathbf{r}$ & $\mathbf{1 2 4}$ & $\mathbf{1 2 8}$ & $\mathbf{1 2 4}^{*}$ \\
\hline 1 & + & + & + & $O \sim a$ & $P a$ & \\
\hline $\mathbf{2}$ & + & + & - & $O \sim a$ & $P a$ & \\
\hline $\mathbf{3}$ & + & - & + & $O \sim a$ & $P a$ & \\
\hline $\mathbf{4}$ & + & - & - & $O \sim a$ & & $O \sim a$ \\
\hline $\mathbf{5}$ & - & + & + & $O \sim a$ & & $O \sim a$ \\
\hline $\mathbf{6}$ & - & + & - & $O \sim a$ & & $O \sim a$ \\
\hline $\mathbf{7}$ & - & - & + & $O \sim a$ & & $O \sim a$ \\
\hline $\mathbf{8}$ & - & - & - & $O \sim a$ & & $O \sim a$ \\
\hline
\end{tabular}

Com base na matriz, salienta que $\mathrm{K}_{1}=\{124,128\}$ é inconsistente nos casos $1-3$, pois se o aborto é proibido, é-o em qualquer circunstância. Por outro lado, o sistema $K^{*}=\left\{124^{*}, 128\right\}$ é consistente e completo. Já no passo seguinte, Maranhão concebe a hipótese de aborto em

\footnotetext{
${ }^{236}$ MARANHÃO, Juliano Souza de Albuquerque. Inclusivismo Lógico: uma contribuição à metodologia jurídica. Tese de livre-docência, Departamento de Filosofia e Teoria Geral do Direito, Universidade de São Paulo, São Paulo, 2010, p. 149.
} 
caso de anencefalia do feto, fazendo remissão à discussão da ADPF n 54-8/DF (a ser tratada no capítulo seguinte).

A partir da matriz acima referida, o autor inseriu como outra propriedade relevante ao sistema $K^{*}=\left\{124^{*}, 128\right\}$, o fator de anencefalia do feto $(f)$, concebendo apenas casos de aborto realizado por médicos, já que a ausência desse fator, implicaria sempre a proibição de aborto. A matriz resultante seria a seguinte:

\begin{tabular}{|l|l|l|l|l|l|l|}
\hline & m & e & r & f & $\mathbf{1 2 8}$ & $\mathbf{1 2 4} *$ \\
\hline 1 & + & + & + & + & $P a$ & \\
\hline $\mathbf{2}$ & + & + & - & + & $P a$ & \\
\hline $\mathbf{3}$ & + & - & + & + & $P a$ & \\
\hline $\mathbf{4}$ & + & - & - & + & & $O \sim a$ \\
\hline $\mathbf{5}$ & + & + & + & - & & $O \sim a$ \\
\hline $\mathbf{6}$ & + & + & - & - & & $O \sim a$ \\
\hline $\mathbf{7}$ & + & - & + & - & & $O \sim a$ \\
\hline $\mathbf{8}$ & + & - & - & - & & $O \sim a$ \\
\hline
\end{tabular}

Segundo o autor "O caso chave é o 4, no qual a norma $124 *$ é uma razão para não realização do aborto. A presença ou ausência da propriedade $f$, aliás, é irrelevante para qualquer das soluções dadas pelas normas 124* e 128”, no entanto, a decisão a seguir abordada (item 3.1.2.3) foi adotada aparentemente em sentido contrário à norma, visto que baseada no princípio da dignidade.

Assim, o passo seguinte do autor foi de demonstrar que por uma inferência abdutiva, possível se fazia encontrar os princípios explicativos da norma penal, de modo que essa decisão pudesse ser considerada como coerente com o Direito posto. Contudo, esse passo final, dentro de sua perspectiva de inclusivismo-lógico, primando pela preponderância de materiais autoritativos e em busca de uma refutação de que o modelo de coerência necessariamente implique moralismo ${ }^{237}$, será explicitado na sequência.

\footnotetext{
${ }^{237}$ Nos modelos de coerência no direito clássicos, sobretudo de MacCormick e Peczenik, as razões morais entram como razões últimas ou justificativas efetivas das decisões judiciais.
} 


\title{
3 ANÁLISE DE CASOS: APLICAÇÃO DOS MÉTODOS E MODELOS
}

O trabalho com a jurisprudência não é, muitas vezes, tarefa fácil de realizar. Os percalços de iniciativas desse teor são notados pela doutrina jurídica pátria, em especial, a doutrina constitucional, bastante familiarizada com as atividades desenvolvidas pela Corte Suprema brasileira, cujo objeto são demandas de natureza constitucional.

Nesse sentido, entre outras dificuldades na análise das decisões judiciais prolatadas pelo STF e, em especial, no caso de conflito de princípios, está primeiramente a adução de argumentos sem a explicitação das nuanças e elementos conducentes à formação da decisão.

A respeito disso, vale citar a consideração de Virgílio Afonso da Silva ao apontar, por exemplo, que em diversas decisões em que o Supremo tenha recorrido à regra da proporcionalidade em casos em que tenha havido a consideração de uma medida como inadequada, desnecessária ou desproporcional em sentido estrito, a posição dos Ministros nem sempre é clara: "Não se sabe. E não há como se saber, visto que o STF não procedeu a nenhum desses exames de forma concreta e isolada. E se não os realizou, não foi aplicada a regra da proporcionalidade, ${ }^{238}$.

Ainda, muito embora o Supremo Tribunal Federal seja órgão de caráter colegiado, o que se constata com Oscar Vilhena ${ }^{239}$ é que

\begin{abstract}
Hoje, o que temos é a somatória de 11 votos (que, em um grande número de casos, já se encontram redigidos antes da discussão em plenário) e não uma decisão da Corte, decorrente de uma robusta discussão entre os Ministros [...] as decisões precisam deixar de ser vistas como uma somatória aritmética de votos díspares. Na realidade, o que o sistema jurídico necessita são decisões que correspondam a um maior consenso decorrente de um intenso processo de discussão e deliberação da Corte. Evidente que sempre deverá haver espaço para votos discordantes e opiniões complementares, mas a maioria deveria ser capaz de produzir uma decisão acordada, um acórdão, que representasse a opinião do Tribunal. Isto daria mais consistência a decisões judiciais de grande impacto político.
\end{abstract}

Disso se nota a dificuldade em se identificar a decisão efetivamente tomada em meio a argumentos díspares e, mesmo, mediante apontamentos não demonstrados, como acima referido por Virgílio Afonso da Silva, o que dificulta a tarefa de elaboração de um estudo

\footnotetext{
${ }^{238}$ SILVA, Virgílio Afonso da. O proporcional e o razoável. Revista dos Tribunais, a. 91, v. 798, p. 23-50, abr. 2002 , p. 34.

${ }^{239}$ VIEIRA, Oscar Vilhena. Supremocracia. Revista Direito GV, n. 4, v. 2, p. 441-464, São Paulo, jul.-dez. 2008, p. 458.
} 
sobre os casos selecionados e, pode, até mesmo, impelir a uma definição estipulativa do que se deve considerar como a decisão prolatada e quais foram os mecanismos utilizados pelos julgadores, como será preciso fazer-se quanto aos casos selecionados.

Ainda, vale reiterar-se que o estudo volta-se exclusivamente a duas decisões prolatadas pelo Supremo Tribunal Federal em casos de conflito de princípios - embora, como se notará, dotados de muitas discordâncias, inclusive quanto ao próprio reconhecimento do conflito -, não se podendo, por conseguinte, fazer uma apreciação genérica do perfil decisório da Corte senão exclusivamente nesses casos.

\subsection{CASO DO ABORTO DE FETOS ANENCÉFALOS (ADPF No 54-8/DF)}

\subsubsection{Questões preliminares}

\subsubsection{Síntese do caso e colocação do problema semântico preliminar}

A decisão da Arguição de descumprimento de preceito fundamental (ADPF) $\mathrm{n}^{\circ}$ 548/DF ${ }^{240}$, em que se discutia a possibilidade de permissão de aborto de fetos anencéfalos, fora uma das mais intrincadas da história do Supremo Tribunal Federal (STF), como reconheceram os próprios julgadores do caso, por este envolver, além de um tema de abrangência multidisciplinar, uma questão ética relativa à vida, culminando na própria judicialização desta: a definição, assaz duvidosa, acerca de sua existência ou não, por um tribunal jurisdicional de cúpula do Poder Judiciário brasileiro.

O caso teve início em junho do ano de 2004, quando fora ajuizada a demanda pela Confederação Nacional dos Trabalhadores na Saúde (CNTS), arguindo que o conjunto normativo representado pelos Arts. 124, 126, caput, e 128, I e II do CP, vulneraria os preceitos constitucionais do Art. $1^{\circ}$, III (dignidade da pessoa humana); Art. $5^{\circ}$, II (legalidade, liberdade e autonomia da vontade) e Arts. 6º caput, e 196 (direito à saúde), todos da CF, razão por que a autora pleiteava interpretação conforme a Constituição desses dispositivos do Código Penal, no intuito de obter declaração de inconstitucionalidade da interpretação desses dispositivos como impeditivos da antecipação do parto em hipótese de gravidez de feto

\footnotetext{
${ }^{240}$ BRASIL. Supremo Tribunal Federal. Arguição de Descumprimento de Preceito Fundamental $\mathrm{n}^{\circ}$ 54-8/DF. Min. Relator Marco Aurélio Mello. Julgada em 12.04.2012. Pendente de Publicação.
} 
anencéfalo, diagnosticados por médico habilitado, reconhecendo-se o direito subjetivo da gestante de se submeter a tal procedimento sem a necessidade de apresentação prévia de autorização judicial ou de qualquer outra forma de permissão específica do Estado.

Em sua postulação, a autora não afirmou categoricamente que fetos anencéfalos não teriam vida, mas sim que não teriam potencialidade de vida extrauterina, razão porque este não seria um caso de aborto - em que o procedimento médico é o responsável por ceifar a vida do nascituro -, mas de antecipação terapêutica do parto, pois a causa mortis seria a máformação congênita e não o procedimento, não se subsumindo, assim, a hipótese ao tipo previsto no Art. 124 do $\mathrm{CP}$, razão pela qual não se deveria criminalizar a conduta da gestante e dos profissionais de saúde que realizassem tal procedimento.

Ainda, a arguente postulava que a permanência de feto anencefálico no útero seria potencialmente perigosa, podendo gerar danos à saúde da gestante e perigo de morte por alto índice de óbitos intrauterinos desses fetos. Dessa maneira, restaria violado o direito à saúde da gestante, tanto do ponto de vista físico, como psicológico (saúde psíquica), uma vez que a autora comparara a gestação de um feto anencéfalo - com potencialidade de vida quase nula a tortura psicológica da mãe, restando a dignidade desta fulminada, bem como sua liberdade para escolher entre levar a termo a gestação ou antecipar o parto.

Assim, a autora defendia que os direitos fundamentais da gestante não colidem com de o outrem, visto que não haveria viabilidade de vida do nascituro. E, embora fosse possível colocar a questão em termos de ponderação de bens ou valores, a rigor técnico, não haveria em sua postulação, necessidade, porque a hipótese não seria de subsunção da situação fática aos dispositivos do Código Penal ${ }^{241}$.

Destarte, pedia concessão de medida cautelar tendo-se em vista a violação aos preceitos fundamentais da dignidade humana, legalidade, liberdade, autonomia da vontade e direito à saúde da gestante, em razão de interpretação das normas penais como impeditivas da antecipação do parto em hipótese de gravidez de feto anencéfalo; bem como em razão de

\footnotetext{
${ }^{241}$ Segundo a arguente, na petição inicial, a discussão jurídica da interrupção da gravidez de feto viável envolveria ponderação de bens supostamente em tensão: potencialidade de vida do nascituro, de um lado, e liberdade e autonomia individuais da gestante, de outro. No caso do feto anencéfalo a arguente postulava a certeza científica de que o feto não teria potencialidade de vida extrauterina. Denotando-se uma interpretação construtiva do Art. 124 do CP, para afastá-lo no caso, pois o tipo penal não se refere a "potencialidade de vida extrauterina", mas a "vida". Em construção dissonante seria possível a sua interpretação de que bastaria haver vida intrauterina - o que parece reconhecer no caso a arguente, posto que fala de morte certa, intra ou extrauterina - para o feto ser objeto de tutela penal, independentemente de sua "viabilidade extrauterina" ou do quantum de sobrevida. Esse foi o entendimento do Ministro Cezar Peluso, conforme se nota em seu voto, de que a seguir se falará.
} 
diversas ações judiais, muitas vezes inócuas pela morosidade, de gestantes para a obtenção de autorização judicial para a antecipação terapêutica do parto por anencefalia do feto ${ }^{242}$.

Isso com o intuito de suspender o andamento de processos ou efeitos de decisões que pretendessem aplicar ou tivessem aplicado os dispositivos do Código Penal, nos casos de antecipação do parto em hipótese de gravidez de feto anencéfalo; bem como, para que se reconhecesse o direito constitucional da gestante de se submeter ao procedimento referido e do profissional de saúde de realizá-lo, desde que atestada por médico habilitado a ocorrência da anomalia descrita na ação.

Tal pedido ensejou a concessão de medida liminar por parte do Ministro Marco Aurélio Mello ${ }^{243}$ em sede de pedido cautelar, anuindo às arguições da autora, sobrestando os processos em andamento relativos ao tema e reconhecendo o direito constitucional da gestante de se submeter à operação terapêutica de antecipação do parto de fetos anencéfalos, a partir de laudo médico atestando a anomalia do feto.

Ou seja, o Ministro Relator, concedeu liminar para suspender a interpretação do Art. 124 do CP que abrangesse a criminalização de aborto de fetos anencéfalos ${ }^{244}$ (sua interpretação construtiva resultaria na seguinte norma penal: Art. 124': o aborto é proibido, salvo em caso de anencefalia do feto (em linguagem simbólica: af/ O a; em linguagem natural: proibido abortar se o feto não é anencéfalo ou permitido abortar feto anencefálico $)^{245}$.

Entre a concessão de tal medida liminar em julho do ano de 2004 e o mês de outubro do mesmo ano, foram realizados diversos procedimentos de antecipação terapêutica do parto de fetos anencéfalos com respaldo em tal decisão. No mês de outubro daquele ano, por ocasião do levantamento de questão de ordem (ADPF 54-8QO/DF) pelo Procurador Geral da República com o questionamento sobre a via utilizada, a adequação de arguição de

\footnotetext{
${ }^{242} \mathrm{Um}$ dos casos claros das notórias divergências fora o $\mathrm{HC}^{\circ}$ 84.025-6/RJ, sob relatoria do Ministro Joaquim Barbosa, referido nesta seção.

${ }^{243}$ A medida liminar não pode ter caráter satisfativo, sob pena de implicar julgamento antecipado do mérito. Por essa razão, a decisão liminar do Ministro Marco Aurélio foi duplamente questionada: tanto por ser medida satisfativa, posto que garantira já ao início da demanda a satisfação da pretensão da arguente; como por implicar, para alguns Ministros da Corte, ativismo judicial, por constituir atividade legislativa por parte de órgão de competência jurisdicional.

${ }^{244}$ Essa foi a decisão analisada por Juliano Maranhão em sua tese de livre docência e que pode ser reiterada no voto do Ministro Relator Marco Aurélio prolatado no presente ano tendo-se em vista que seu voto fora no sentido de reiterar a medida liminar concedida. Vide: MARANHÃO, Juliano Souza de Albuquerque. Inclusivismo Lógico: uma contribuição à metodologia jurídica. Tese de livre-docência, Departamento de Filosofia e Teoria Geral do Direito, Universidade de São Paulo, São Paulo, 2010.

${ }^{245}$ Em conjunção com as demais excludentes do Art. 128 do $\mathrm{CP}$, a leitura resultante seria $\mathrm{O} \sim \mathrm{a} \rightarrow \sim$ af $\Lambda \sim \mathrm{m} \wedge \sim \mathrm{e}$ ou $\mathrm{Pa} \rightarrow$ af $v \mathrm{~m} v$ e (é permitido abortar se o feto é anencéfalo ou a mãe corre risco de morte ou a gestação foi resultante de estupro). Esse é o resultado da decisão do STF na ADPF nº 54-8/DF.
} 
descumprimento de preceito fundamental no caso $^{246}$; em reunião plenária ${ }^{247}$, os Ministros do STF decidiram, por maioria - sob o entendimento de não prevalecer em ADPF liminar no sentido de afastar o tipo penal para que se realizasse interrupção de gravidez no caso de anencefalia - revogar a segunda parte da medida liminar concedida pelo Ministro Marco Aurélio, em que se reconhecia o direito constitucional da gestante de se submeter à operação terapêutica de parto de fetos anencéfalos ${ }^{248-249}$.

Resolvida a questão de ordem em abril do ano de 2005, em decisão da maioria pela adequação da ADPF, foram realizadas quatro audiências públicas entre os meses de agosto e setembro do ano de 2008, nas quais ficou claramente evidenciada a divergência quanto à questão semântica relativa ao feto anencéfalo e a consequente implicação da existência ou não de vida em tais casos.

Segundo alguns dos membros da comunidade científica, além de o feto anencéfalo ter vida, defendiam que não seria meramente orgânica, mas que esse feto seria portador de sensações, dores e consciência; já outros consideraram-no "natimorto cerebral", a despeito da reconhecida manifestação vital, ao menos orgânica, intrauterina.

Também se patenteou a divergência sobre a abrangência semântica do termo anencefalia. Diversos médicos reiteraram a necessidade de entendimento do termo em sentido não literal tendo-se em vista a etimologia, que induziria a conclusão incorreta de "ausência de cérebro", quando o caso seria de ausência de fechamento da calota craniana ou dos hemisférios cerebrais, havendo, contudo, demais componentes do que se entende por

\footnotetext{
${ }^{246}$ O que o representante do Ministério Público questionava é se a ADPF servia para se buscar "interpretação conforme", uma vez que entendia que os Arts. 124, 126 e 128 do Código Penal se caracterizavam por univocidade de conteúdo e alcance, traduzida na criminalização e apenamento de toda prática abortiva que não as expressamente ressalvadas pelos incisos I e II do art. 128 do Código Penal.

${ }^{247}$ Como o Tribunal encontrava-se em férias coletivas quando do pedido liminar, o Ministro Relator julgou a medida cautelar sob o dever de submetê-la posteriormente ao plenário, consoante ditames do Regimento Interno do STF.

${ }^{248} \mathrm{Na}$ ocasião, portanto, entendeu-se pela subsunção da hipótese ao tipo penal constante dos Arts. 124 e 126 do $\mathrm{CP}$ até que não houvesse decisão de mérito.

${ }^{249}$ Em sede de questão de ordem o então Ministro Eros Grau questionou a segunda parte da medida liminar concedida pelo Relator, a qual não fora referendada pelo plenário, por entendê-la como "autorizando a prática de uma terceira modalidade de aborto não prevista na Constituição", dado seu entendimento de que se tratava de "liminar satisfativa que, durante quatro meses, permitiu que - como se a lei tivesse sido reescrita, como se o Código Penal tivesse sido reescrito pela Corte, como legislador positivo - permitiu que uma terceira modalidade de aborto passasse a ser admitida". No mesmo sentido posicionou-se o Ministro Cezar Peluso ao asseverar que "A simples leitura dos termos da petição inicial evidencia que esta pretende criar uma excludente de ilicitude contra a clareza do sentido emergente de um conjunto de normas que jamais provocaram, até hoje, dúvida alguma de interpretação, tanto na doutrina, como na da jurisprudência". Os Ministros Ellen Gracie e Carlos Velloso ratificaram o entendimento. Igualmente, o Ministro Gilmar Mendes cogitou dessa hipótese. BRASIL. Supremo Tribunal Federal. Questão de Ordem em Arguição de Descumprimento de Preceito Fundamental no $54-$ 8/DF. Min. Relator Marco Aurélio Mello. Julgada em 27.04.2005. D.J. 31.08.2007. Disponível em: <http://redir.stf.jus.br/paginadorpub/paginador.jsp?docTP=AC\&docID=484300>. Acesso em: 19 mar. 2012, p. 85 e 98.
} 
encéfalo, a começar pelo tubo neural que, para alguns dos amigos da corte, propiciaria não apenas a vida vegetativa como também percepções sensórias e emocionais, embora não passíveis de expressão.

Igualmente se constaram profundas divergências, todas com respaldo em dados e registros científicos, quanto à efetividade de riscos maiores à gestante em caso de gravidez de fetos anencéfalos: parte da comunidade médica afirmou categoricamente que haveria riscos potencializados, outros disseram que não seriam agravados em relação aos riscos normais de uma gestação comum e que seriam até menores do que em gestação gemelar ${ }^{250}$.

No mesmo sentido, houve dissenso sobre a existência ou não de atividade cerebral em fetos anencéfalos: alguns pesquisadores disseram não ser possível se constatar atividade cerebral pela impossibilidade de se fazer exame de eletroencefalograma; outros, além de consideraram possível tal exame, fizeram referência a registros de pesquisas norte-americanas com fetos anencéfalos que sobreviveram, em que a atividade cerebral fora constatada.

A própria existência ou não de vida em caso de feto anencéfalo foi um dos pontos de profunda discordância. O caso Marcela, de uma criança diagnosticada com anencefalia que (sobre)viveu durante um ano e oito meses, é altamente emblemático acerca dessa divergência: os amici curiae que se manifestaram contrariamente à antecipação terapêutica do parto, usavam o caso de Marcela, como exemplo da equivocidade da tese de que seriam nulas as chances de sobrevida de um anencéfalo, o que fora fundamento dos defensores da antecipação do parto nesses casos, já que estes arguiam que o caso de Marcela não seria de anencefalia, mas fora um erro de diagnóstico.

Como notou o Ministro Cezar Peluso, isso demonstrara a delicadeza da questão, pois os defensores da antecipação arguiam que não haveria erro médico na matéria e, ao mesmo tempo, para defender uma de suas teses, da impossibilidade de sobrevida, minavam a outra, reconhecendo um caso de erro médico.

Inclusive, a determinação ou entendimento acerca da existência ou não de vida em fetos anencéfalos - questão que transcende a perspectiva estritamente semântica, abrangendo um campo multidisciplinar - fora fator decisivo no posicionamento dos amici curiae e dos próprios Ministros do STF em suas deliberações sobre a procedência - pela permissão da

\footnotetext{
250 Segundo informação de Doutor Dernival da Silva Brandão (médico Especialista em Ginecologia e Obstetrícia; Especialista em Medicina do Trabalho pela PUC do Rio de Janeiro; membro titular da Academia Fluminense de Medicina e presidente da Comissão de Ética e Cidadania da Academia Fluminense de Medicina) prestada na terceira audiência pública na data de 04 de setembro de 2008, consoante notas taquigráficas. BRASIL. Supremo Tribunal Federal. Arguição de Descumprimento de Preceito Fundamental no 54-8/DF. Notas taquigráficas da Audiência Pública de 04 de setembro de 2008. Disponível em: <http://www.stf.jus.br/arquivo/cms/processoAudienciaPublicaAdpf54/anexo/ADPF54_notas_dia_4908.pdf>. Acesso em: 19 mar. 2012.
} 
antecipação do parto de anencéfalo como hipótese que não se subsume ao crime de aborto ou, ao menos, da subsunção em uma das excludentes do Art. 128 do CP, quando do entendimento da existência de vida - ou não da ADPF.

Ou seja, os Ministros que entenderam que o anencéfalo não é ser dotado de vida votaram no sentido do Ministro relator pela procedência da ADPF, por entenderem que não havendo vida, não se tratava do tipo penal descrito no Art. 124 do $\mathrm{CP}$ e, por sua não subsunção, seria conduta permitida.

Embora reconhecesse a existência de vida, o Ministro Gilmar Mendes entendia o caso como de terceira hipótese de excludente de ilicitude, ainda não explicitada no Código Penal. Já os demais Ministros, Ricardo Lewandowski e Cezar Peluso, que entenderam haver vida no caso de feto anencéfalo, votaram pela improcedência da demanda pelo entendimento de que, havendo vida, o feto seria sujeito passivo do crime de aborto, embora as fundamentações de ambos sejam diferenciáveis.

\subsubsection{Síntese dos votos dos julgadores}

No lapso entre o começo do processo em 17 de junho de 2004 e a sessão plenária de seu julgamento nos dias 11 e 12 de abril de 2012, a estrutura e perfil da Corte Suprema mudaram substancialmente. Dos onze ministros inicialmente presentes - Marco Aurélio Mello, Celso de Mello, Eros Grau, Ellen Gracie, Sepúlveda Pertence, Carlos Velloso, Nelson Jobim, Joaquim Barbosa, Carlos Ayres Britto, Cezar Peluso e Gilmar Mendes -, apenas seis permaneceram na Corte: Marco Aurélio, Celso de Mello, Joaquim Barbosa, Ayres Britto, Cezar Peluso e Gilmar Mendes.

Entre o julgamento da questão de ordem no ano de 2004, em que alguns dos Ministros já demonstravam suas posições e o julgamento definitivo em 2012, pode-se notar a divergência entre os Ministros que se afastaram da Corte e os que os sucederam, tal como ocorrera em que relação à sucessão na Procuradoria Geral da República, uma vez que o Procurador em exercício quando do ajuizamento da demanda opinara por sua total improcedência e, o Procurador em exercício, quando do julgamento de mérito da Corte em 2012, opinou por sua total procedência.

No julgamento em plenário, dos onze Ministros da Corte, nove prolataram seus votos, tendo o Ministro Dias Toffoli se abstido, uma vez que aturara como Advogado Geral da 
União quando do ajuizamento da $\mathrm{ADPF} \mathrm{n}^{\circ}$ 54-8/DF, ocasião em que se pronunciara pela procedência da demanda.

Já o Ministro Joaquim Barbosa, embora não tenha manifestado seus argumentos perante o plenário, corroborou integralmente sua decisão anteriormente tomada em medida liminar no HC 84.025-6/RJ ${ }^{251}$ em que se pleiteava a autorização judicial para antecipação de parto de feto anencéfalo, já levado à apreciação do STF, mas não julgado uma vez que a gestação do feto chegou a termo antes do julgamento pelo plenário, ficando, portanto, o julgamento prejudicado por tal fato superveniente.

Esse caso revela a grande celeuma sobre o tema. Inicialmente, a paciente do habeas corpus impetrado perante o STF, ajuizou por meio da Defensoria Pública do Rio de Janeiro pedido de autorização judicial para a realização de aborto, tendo em vista o diagnóstico de anencefalia do feto que gestava. Em primeira instância, o juízo indeferiu liminarmente o pedido sob o fundamento de falta de previsão legal, uma vez que a hipótese não estaria no rol de excludentes de ilicitude previstas no Art. 128 do CP.

Foi interposto recurso de apelação, distribuído à Segunda Câmara Criminal do Tribunal de Justiça do Rio de Janeiro (TJRJ). Na ocasião, em 19 de novembro do ano de 2003, a desembargadora relatora concedeu a medida liminar, autorizando a interrupção da gravidez, sob o entendimento de que, embora houvesse vida em curso, esta estaria fadada ao óbito e a vida deveria ser ponderada com o sofrimento e angústia da mãe.

O fato fora noticiado pela mídia e desembargadores aposentados, como advogados, com fundamento no direito de petição (Art. $5^{\circ}, \mathrm{XXXV}$ da $\mathrm{CF}$ ), interpuseram agravo regimental à Segunda Câmara, cujo presidente suspendeu a decisão da relatora em 21 de novembro de 2003 e, dois dias depois, o agravo regimental foi desprovido e a decisão liminar autorizando o aborto foi mantida; tendo já no dia 21 do mesmo mês e ano, a Associação Próvida impetrado perante o Superior Tribunal de Justiça (STJ) um habeas corpus para desconstituir a decisão monocrática da desembargadora do TJRJ, que fora confirmada pelo Tribunal de Justiça do Rio de Janeiro, como referido.

O feito no STJ foi distribuído à Ministra Laurita Vaz que, no mesmo dia 25 de novembro de 2003 - quando a decisão liminar da desembargadora pela autorização da interrupção da gravidez foi confirmada pelo TJRJ - concedeu liminar em sentido contrário:

\footnotetext{
${ }^{251}$ BRASIL. Supremo Tribunal Federal. Habeas Corpus no $84.025-6 /$ RJ. Ministro Relator Joaquim Barbosa. Julgado em 04.03.2004. D.J. 25.06.2004. Disponível em: <http://redir.stf.jus.br/paginadorpub/paginador.jsp?docTP=AC\&docID=384874 >. Acesso em: 21 out. 2011.
} 
para sustar a decisão do TJRJ até apreciação final do habeas corpus pela Quinta Turma do STJ.

Após diligências e recesso forense, já em 18 de abril de 2004, o STJ julgou o habeas corpus indeferindo o pedido de interrupção de gravidez sob fundamento de falta de previsão legal e de impossibilidade, no caso, de interpretação extensiva ou analogia in malam partem em relação ao feto.

E, ante tal decisão, entidades sociais impetram o Habeas Corpus distribuído perante o Supremo Tribunal Federal (STF) sob $\mathrm{n}^{\circ} 84.025-6 / \mathrm{RJ}^{252}$, sob relatoria do Ministro Joaquim Barbosa, alegando coação por parte do STJ à necessidade de tutela à liberdade, saúde física e mental e à dignidade humana da gestante e pedindo a cassação do acórdão do STJ para autorizar a paciente à realização da antecipação do parto.

Já em 04 de março de 2004, o Ministro Joaquim Barbosa posicionou-se no sentido de que a decisão do STJ não reconhecera os direitos da gestante, dando atenção exclusiva aos do nascituro, o que evidenciara o constrangimento da decisão à gestante. O Ministro reconheceu o conflito de princípios, admitindo o direito à vida em sentido amplo do feto e sua contraposição com a liberdade e a autonomia privada da mulher, concluindo pela prevalência da dignidade desta, do que se infere que aquelas, liberdade e autonomia, são, para o Ministro, decorrência da dignidade.

Até mesmo porque, embora reconhecesse a vida do feto anencéfalo, entendia o Ministro que seria apenas vida biológica, distinguindo entre feto em pleno desenvolvimento, biologicamente morto e biologicamente vivo, mas juridicamente morto. Este último seria, para ele, o caso do anencéfalo, e, portanto, ele não estaria tutelado pelo Direito Penal, posto que a tutela seria apenas para o primeiro caso.

Assim, para o Ministro, desde a concepção até a constatação de anencefalia, o feto seria merecedor de tutela penal, mas, a partir do diagnóstico de anencefalia, embora continuasse biologicamente vivo não mais estaria amparado pelo Art. 124 do $\mathrm{CP}$, de modo que, no entender do Ministro Joaquim Barbosa, a conduta de antecipação do parto de anencéfalos não se subsumiria a esse tipo penal, sendo, pois, atípica.

Nesse sentido, o Ministro arguiu que o objeto jurídico tutelado pelos Arts. 124, 126 e 128 do CP seria, de um lado a preservação de uma vida potencial, e de outro, a incolumidade

\footnotetext{
${ }^{252}$ BRASIL. Supremo Tribunal Federal. Habeas corpus $\mathrm{n}^{\circ}$ 84.025-6/RJ. Min. Relator: Joaquim Barbosa. Julgado em 04.03.2004. D.J. 25.06.2004, p. 04. Disponível em: <http://redir.stf.jus.br/paginadorpub/paginador.jsp?docTP=AC\&docID=384874 >. Acesso em: 21 out. 2011.
} 
da gestação. No caso de feto anencéfalo, o Ministro afastou a potencialidade de vida, alegando haver impossibilidade de sobrevida do feto anencéfalo fora do útero materno.

Assim, o Ministro remeteu às causas de exclusão de ilicitude, constitutivas das duas exceções à regra do Art. 124 do CP: o caso de aborto necessário, em que a vida da mãe está em perigo (Art. 128, I); e a hipótese de aborto sentimental, em que, em sua concepção, a honra da mãe seria violada tornando insustentável a manutenção da gravidez (art. 128, II). Nesses casos, o Ministro reiterou que a norma penal chancela a liberdade da mulher, não incriminando sua conduta.

Partindo desse raciocínio, o Ministro entendeu que, em casos de anencefalia, uma interpretação que tipificasse a conduta como aborto (Art. 124 do CP) seria desproporcional em comparação à tutela legal da autonomia privada da mulher de escolher manter ou interromper a gravidez nos casos citados de exclusão de ilicitude, o que seria especialmente desproporcional, porque nesses casos há interrupção de gestação de feto cuja vida extrauterina é plenamente viável, diferente do anencéfalo.

Então, em um raciocínio coerentista, tendo em vista a ponderação do legislador penal, o Ministro Joaquim Barbosa entendeu ser incoerente chancelar a liberdade e a autonomia privada da mulher no caso de aborto terapêutico e sentimental e vedar a liberdade de escolha em casos de má-formação fetal gravíssima, como a anencefalia, até porque neste caso não haveria, para ele, real conflito entre bens jurídicos detentores de idêntico grau de proteção jurídica, mas clara prevalência da dignidade da mulher, já que a vida do anencéfalo não seria passível de tutela jurídica.

Assim, em seu voto (corroborado no julgamento da ADPF n ${ }^{\circ}$ 54-8/DF), o Ministro Joaquim Barbosa concedeu a ordem para cassar a decisão do STJ, e permitir à paciente a antecipação do parto do feto anencéfalo. Não obstante, o plenário do STF não chegou a julgar o mérito do feito, uma vez que, dada a morosidade no julgamento - e as divergências nas diversas instâncias - a gravidez da paciente chegara naturalmente a termo e a criança já havia morrido.

Com isso, ensejou-se o ajuizamento em junho do mesmo ano de 2004 da ADPF no 548/DF permitindo-se decisão erga omnes, cujo mérito, finalmente, fora julgado apenas no presente ano, conforme votos a seguir ainda pendentes de publicação, mas divulgados nas sessões plenárias dos dias 11 e 12 de abril de 2012, sob transmissão ao vivo pelo canal TV Justiça. 


\subsection{Voto do Ministro Marco Aurélio Mello}

O voto do Ministro Relator Marco Aurélio, no mérito, seguiu-se sem alterações em relação à medida liminar por ele concedida e a suas manifestações já em sede de audiências públicas, no sentido de julgar procedente a demanda para o fim de declarar a permissão de aborto de fetos anencéfalos por interpretação conforme a Constituição, sobretudo em relação ao Art. $1^{\circ}$, III da CF em que se prevê o princípio da dignidade humana.

Em sua linha de argumentação, o Ministro salientou reiteradamente que o Estado brasileiro é laico e, portanto, que não se deveria haver ingerência religiosa em assuntos do Estado $^{253}$, tendo este como princípios fundamentais a dignidade da pessoa humana, o direito à vida, a proteção da autonomia e a saúde.

O Ministro partiu da premissa de que o feto anencéfalo é destituído de atividade cerebral, de consciência, de cognição, de afetividade e vida relacional, considerando-o como "morto cerebral"; o que o levou ao entendimento de que, no caso, não havia real colisão de direitos fundamentais, mas apenas conflito aparente, visto não reconhecer vida no feto anencefálico - sequer reconhecera potencialidade de vida -, e sim a dignidade da gestante.

E, como entendeu que o anencéfalo não teria vida, concluiu que a conduta de interromper a gravidez de feto anencéfalo é atípica, não se subsumindo, pois, ao conjunto típico dos Arts. 124, 126 e 128, I e II do CP, visto que o crime de aborto voltar-se-ia à tutela de vida potencial e, no caso de anencéfalo, em seu entender, não haveria vida possível. Assim, seria caso de antecipação terapêutica do parto, como alegara a arguente na inicial, o que se distinguiria de aborto.

Nesse sentido, o Ministro traçou a comparação, a ser posteriormente reiterada (item 3.1.2.3), entre a situação da norma permissiva (Art. 128, II do CP), em caso de estupro, em que é permitido o aborto ainda que o feto seja plenamente viável, em razão do princípio da dignidade da gestante violada; e o caso de gestação de feto anencéfalo, em que seria, para o Ministro, ilógico que se protegesse um feto sem potencialidade de vida por tipo penal que tutela a vida, quando esta é excepcionada em caso de colisão com a dignidade da mãe.

Assim, no caso referido de aborto sentimental, o Ministro reitera que o legislador já ponderara entre o direito à vida do feto (viável) e a dignidade da mãe violada, adotando o tipo

\footnotetext{
${ }^{253}$ Segundo o Ministro Marco Aurélio, concepções morais e religiosas não podem guiar as decisões estatais. Inclusive sua ênfase ao assunto levou a questionamentos - dos Ministros Gilmar Mendes e Celso de Mello -, ainda que não críticos ou efetivamente explícitos, se a oitiva de entidades religiosas em audiências públicas foi mesmo observada, senão apenas permitida pro forma.
} 
permissivo do art. 128, II do CP como caso de aborto ético ou humanitário, sem que tivesse havido até então questionamento sobre a constitucionalidade desse dispositivo.

Também reiterou não ser o direito à vida absoluto e, ao cotejar as penas de crimes contra a vida nos casos de homicídio (Art. 121 do CP) e infanticídio (art. 123 do CP) registrou que tais normas demonstrariam que o direito à vida sofre variações, com proteção mais ampla à medida que ocorre o desenvolvimento.

Assim, o embrião seria, a seu ver, ser humano, mas não pessoa, não sendo passível da mesma tutela que a mãe. E, no caso de anencéfalos, entendeu que, ainda que tivessem vida embora discordasse dessa premissa - se a ponderação do legislador entre a vida do feto saudável e a dignidade ou vida da mulher, preponderando os últimos princípios, fora feita, com maior razão no caso de anencéfalos que, para Marco Aurélio, não têm vida ou, tendo-a, seria considerada de "menor valor" do que de um feto viável, a dignidade e liberdade da mulher prevaleceriam.

Desse modo, respaldado em dados coletados em sede de audiências públicas, apesar das divergências nelas constatadas, o Ministro fundamentou seu voto alegando que a interpretação da antecipação do parto de anencéfalo como aborto violaria o direito à saúde, pois a gestação desses fetos envolveria maiores riscos à gestante, bem como pelas consequências psicológicas dramáticas que lhe acarretaria e pelo risco de intercorrências na gestação; ainda, atingiria os direitos humanos, abrangendo os direitos sexuais e reprodutivos, não sendo lícito ao Estado imiscuir-se na intimidade da mulher, comparando a obrigatoriedade desta de manter a gestação de anencéfalo a situação de tortura.

Concluiu, assim, que o feto anencéfalo não seria detentor de direito à vida e, se nele houvesse vida, esta cederia aos direitos da gestante, com base nos Arts. $1^{\circ}$, III; $5^{\circ}$, caput e incisos II, III e X; e Art. $6^{\circ}$, caput, todos da CF. Por tal razão, seria direito da mulher decidir sobre a manutenção da gestação ou antecipação terapêutica do parto de feto anencéfalo. Destarte, o Ministro julgou procedente a demanda declarando a inconstitucionalidade da interpretação segundo a qual a interrupção de gravidez de anencéfalos é conduta típica.

\subsection{Voto da Ministra Rosa Maria Weber}

A Ministra Rosa Maria Weber passou a integrar o STF em dezembro do ano de 2011, tendo sucedido à Ministra Ellen Gracie que, em sede de julgamento de questão de ordem (ADPF $n^{\circ}$ 54-8 QO/DF) mostrava-se propensa a julgar improcedente a ADPF - no sentido do 
Ministro Ricardo Lewandowski, consoante a seguir explanado -, diferentemente de Rosa Maria Weber, que a julgou procedente seguindo o Ministro Relator.

A Ministra Rosa Maria partiu da questão semântica sobre o conceito de vida sob a perspectiva do Direito, salientando, tal como o Ministro Relator que, ao tipificar os crimes contra a vida, fez-se no Código Penal brasileiro gradação na importância da vida em diferentes tipos penais, cujo bem tutelado é a vida, mas com cominações diversas de penas, exemplificado inclusive que lesão corporal grave (em que o bem tutelado é a integridade física) tem pena maior do que o crime de aborto.

Também se reportou ao Art. 128, II do CP em que o estupro é considerado como causa excludente de ilicitude denotando que o direito à vida não é valor único e absoluto. Não obstante, salientou que para o Direito Penal só há aborto se houver vida, embora não se defina esta e, por raciocínio a contrario concluiu que, se a Lei $\mathrm{n}^{\circ} 9.434 / 2007$, ao regulamentar a doação de órgãos e tecidos humanos, definiu em seu Art. $3^{\circ}$ morte como morte encefálica, entendeu ser vida a atividade cerebral não restrita à vida orgânica, mas à consciência, socialidade e capacidade de resposta.

A partir disso, a Ministra concluiu que, sendo a anencefalia incompatível com a ideia de vida defendida pelo Direito, a antecipação terapêutica do parto de anencéfalo seria fato atípico, não se subsumindo ao crime de aborto; e a interpretação em sentido contrário seria violação à liberdade de escolha da mulher e à sua dignidade, reiterando, assim, a decisão do Ministro Relator.

\subsection{Voto do Ministro Luiz Fux}

O Ministro Luiz Fux também passou a integrar a Corte no ano de 2011, tendo sucedido ao Ministro aposentado Eros Grau, cuja orientação em manifestação no julgamento da questão de ordem ${ }^{254}$ (ADPF $\mathrm{n}^{\text {o }}$ 54-8 QO/DF) era aparentemente no sentido de julgar improcedente o pedido da arguente.

\footnotetext{
${ }^{254} \mathrm{Na}$ ocasião, o Ministro Eros grau manifestou-se dizendo que a liminar do Ministro Marco Aurélio era "uma liminar da vida, mas contra a vida, pelo menos contra a vida reconhecida pelo artigo $2^{\circ}$ do Código Civil", o que denota seu reconhecimento da vida do feto anencéfalo, orientando-se aparentemente pela subsunção da conduta de antecipar seu parto ao aborto. BRASIL. Supremo Tribunal Federal. Questão de Ordem em Arguição de Descumprimento de Preceito Fundamental $\mathrm{n}^{\circ}$ 54-8/DF. Min. Relator Marco Aurélio Mello. Julgada em 27.04.2005. D.J. 31.08.2007. Disponível em: $<$ http://redir.stf.jus.br/paginadorpub/paginador.jsp?docTP=AC\&docID=484300>. Acesso em: 19 mar. 2012, p. 85 .
} 
Já o Ministro Luiz Fux entendeu que o feto anencéfalo seria incapaz de sentir e ser consciente e não se justificaria a criminalização da conduta da mulher em tal caso, visto que até mesmo em situação em que o feto é considerado sadio, o legislador realizou a ponderação de princípios (vida do feto $\mathrm{X}$ dignidade da mãe), fazendo preponderar a dignidade da mulher (Art. 128, II do CP).

Assim, para Luiz Fux, permitir o aborto sentimental em caso de feto sadio e negá-lo em caso de feto anencéfalo considerando-se a conduta da mãe como crime, seria desproporcionalidade até mesmo em se considerando a violação de sua dignidade e de sua saúde psíquica.

Razão pela qual o Ministro, na esteira do Relator, votou pela procedência da ADPF para conferir interpretação conforme à Constituição dos dispositivos penais, de modo a que a antecipação terapêutica do parto de fetos anencéfalos não se subsumisse ao delito de aborto.

\subsection{Voto da Ministra Carmen Lúcia}

Em seu voto, a Ministra Cármen partiu da premissa de que a antecipação terapêutica do parto de fetos anencéfalos não seria caso de aborto e, com maior razão, tampouco de aborto eugênico. Pautando-se sua decisão no direito à vida, à liberdade e à responsabilidade da mulher.

A Ministra concluiu que deveria prevalecer a liberdade de escolha da mulher, analogamente à excludente do Art. 128, I do CP em que o aborto necessário é causa excludente como resultado da ponderação do legislador fazendo prevalecer a saúde da mãe em detrimento da vida do nascituro. A Ministra, em interpretação construtiva, asseverou que no caso de anencéfalo também se haveria de tutelar a saúde psíquica da mãe, tal como no dispositivo citado há a tutela de sua saúde física.

Assim, julgou procedente a ADPF acolhendo os fundamentos da arguente e entendendo que a antecipação terapêutica do parto de feto anencefálico não se subsume à conduta típica do aborto.

\subsection{Voto do Ministro Ricardo Lewandowski}

Pode-se considerar que o princípio da separação de poderes é dos principais fundamentos para o julgamento improcedente da ADPF $\mathrm{n}^{\circ}$ 54-8/DF por parte do Ministro 
Ricardo Lewandowski. Em seu voto, o Ministro reconheceu o conflito entre direito à vida do nascituro e o direito à vida e a incolumidade física da gestante, mas entendeu que a conduta desta no caso de antecipação de parto de anencéfalos seria típica não se podendo cogitar de excludente de ilicitude no caso.

Destarte, entendeu que a conduta de antecipar o parto de feto anencéfalo subsume-se à conduta típica de aborto, uma vez que o legislador criara duas hipóteses explícitas e taxativas, já pressuposta a prática de aborto por médico: o caso de aborto necessário (Art. 128, I do CP) e o caso de aborto sentimental (Art. 128, II do CP), não tendo excluído também a punibilidade no caso de aborto de feto mal formado, tendo-o considerado típico.

Assim, o Ministro afastou o argumento da arguente de que o Código Penal não teria inserido a excludente devido à sua vetustez, uma vez que, para Lewandowski, se fosse o caso de fazer a inserção, o legislador penal já a teria feito, por exemplo, quando da reforma da parte geral do Código no ano de 1984, quando já havia técnicas suficientes para se diagnosticar a anencefalia e, no entanto, os parlamentares não mudaram a lei penal.

Segundo o Ministro, embora a interpretação conforme a Constituição fosse preferível à declaração de inconstitucionalidade - pela presunção de conformação do legislador aos ditames constitucionais -, a interpretação conforme, requerida pela arguente, teria como limites não se afrontar a literal expressão da lei, não contrariar a vontade manifesta do legislador e, com maior razão, não se substituir a ele.

A esse respeito, o Ministro salientou que a alteração de conteúdos normativos é tarefa do legislador e não do Tribunal Constitucional e, por conseguinte, o STF só poderia exercer papel de legislador negativo e não positivo, usurpando competência alheia a suas atribuições. E, no caso, entendeu que a legislação penal não admitia ampliação das hipóteses de aborto autorizado, em razão da clareza de seu enunciado.

O Ministro ainda citou projetos de lei em trâmite no Congresso Nacional, um dos quais para incluir no Art. 128 do $\mathrm{CP}$ a anencefalia como outra hipótese de excludente, apontando que o legislador não se encorajara a resolver a questão e não seria lícito submetê-la à Corte Constitucional no intuito de que esta se substituísse ao legislador, pela elaboração de norma abstrata autorizadora do aborto dito terapêutico em caso de suposta anencefalia fetal, como entende ter sido a pretensão da arguente.

Assim, o Ministro entendeu que a pretensão da autora era de se criar outra causa de exclusão de punibilidade ou, o que lhe parecera pior, uma hipótese de exclusão de ilicitude o que é mesmo o entendimento da arguente ao postular que não há vida e, portanto, a antecipação terapêutica do parto não subsumiria ao crime de aborto. Portanto, o Ministro do 
Ricardo Lewandowski julgou improcedente a demanda, por entender que o feto anencéfalo tem vida e que a antecipação de parto se subsume ao crime de aborto.

\subsection{Voto do Ministro Carlos Ayres Britto}

O Ministro Carlos Ayres Britto alinhou-se ao entendimento do Ministro Relator no sentido de que não haveria vida no feto anencéfalo e, portanto, a antecipação terapêutica do parto de anencéfalo seria conduta permitida, posto que atípica.

Segundo o Ministro, os dispositivos penais discutidos na demanda seriam polissêmicos e, por conseguinte, admitiriam diversas interpretações, levantando três delas como defensáveis. A primeira seria de que a antecipação terapêutica de parto de feto anencéfalo seria crime sob o fundamento de que o início da vida humana dá-se na concepção e, portanto, bastaria para a criminalização do aborto a conduta provocada ou consentida com o intuito de impedir que um feto viesse a concluir todo o ciclo da formação humana, ainda que a vida humana se encontrasse em estado latente.

Tanto assim, que se refere ao Código Civil (CC) brasileiro que, para fins de sucessão hereditária, põe a salvo os direitos do nascituro (art. $2^{\circ}$ do CC), bem como ao Pacto de São José da Costa Rica, cujo Art. $4^{\circ}, n^{\circ} 1$ assegura o direito à vida a partir do momento da concepção.

A segunda interpretação plausível seria de que não há crime de aborto em caso de "natimorto cerebral", por "inviabilidade vital", o que seria o caso de feto anencéfalo segundo a resolução no 1.752/04, do Conselho Federal de Medicina. Entendendo-se que, no caso, não haveria um ser humano, até porque, se a criminalização do aborto se dá como política legislativa de proteção à vida de um ser humano em potencial, faltando essa potencialidade vital, aquela vedação penal já não teria como permanecer.

Desse modo, a interrupção da gravidez de anencéfalo seria aborto apenas em linguagem coloquial, mas não em linguagem jurídica. Conforme essa interpretação também valeria o raciocínio a contrario, já que consoante o Art. $3^{\circ}$ da Lei $n^{\circ}$ 9.434/97 há correlação entre morte encefálica e cessação da vida humana, o que teria inspirado o Conselho Federal de Medicina a dispor que os anencéfalos teriam inviabilidade vital em decorrência da ausência de cérebro - apesar de ser essa a etimologia da palavra, as audiências públicas apresentaram as divergências quanto à amplitude semântica do termo, como já descrito. 
Finalmente, a terceira interpretação possível seria de que a antecipação terapêutica do parto de feto anencéfalo é fato típico, mas sem configurar prática penalmente punível, tendo como razão para sua despenalização o abalo psíquico e a dor moral da gestante. Aplicar-se-ia ainda o brocardo latino ubi eadem ratio, ibi eadem legis dispositio, a se traduzir na fórmula de que onde existe a mesma razão decisiva prevalece a mesma regra de Direito.

Partindo dessa colocação, embora sob o entendimento de que o feto anencéfalo é destituído de vida, expõe que no caso de anencefalia a razão seria a mesma do caso de estupro em que há a excludente do Art. 128, II do CP, já que neste caso o que se tutela é a dignidade da pessoa humana, pois corresponderia a tortura compelir a mulher a levar a cabo uma gestação resultante de violência sexual.

Também no caso da gestação de feto anencéfalo, entendeu o Ministro que a gestante sofre abalo psíquico-moral que equivaleria à tortura, por saber que o feto inevitavelmente morrerá, o que lhe causa tortura psicológica semelhante ao caso de estupro, violando-lhe a dignidade, razão porque também se justificaria a excludente no caso de antecipação de parto de feto anencéfalo, em raciocínio coerente com o do legislador penal.

Logo, como o Ministro Ayres Britto entende que o feto anencéfalo, por ser destituído dos hemisférios cerebrais não tem sensação, percepção e sequer potencialidade vital, se a antecipação do parto fosse considerada crime, não seria para ele prática penalmente punível, uma vez que a dignidade da gestante supera a potencialidade de vida do feto, de que sequer cogita. Mas, concluiu que se tratava de caso de atipicidade da conduta, uma vez que não se poderia dar ao conjunto normativo do Código Penal caracterização do direito de escolha da gestante como aborto.

Deste modo, o Ministro julgou procedente o pedido da inicial para declarar a inconstitucionalidade da interpretação segundo a qual a interrupção de gravidez de feto anencéfalo é conduta tipificada pelo conjunto dos Arts. 124, 126 e 128, I e II do CP.

\subsection{Ministro Gilmar Mendes}

O Ministro Gilmar Mendes também se posicionou favoravelmente à arguição, julgando-a procedente, mas em sentido diverso dos demais Ministros, visto que Gilmar Mendes entendeu a antecipação de parto como uma terceira causa excludente de ilicitude. 
Ao invocar o direito comparado, referiu-se ao fato de que em diversos países europeus a antecipação do parto em caso de anencéfalos é considerada como conduta atípica, recebendo a devida regulamentação sobre diagnóstico e procedimentos para essa antecipação.

O Ministro apontou o dissenso sobre a necessidade de se conferir tutela jurídica ao feto anencéfalo, o qual pode nascer com vida, com maior ou menor duração. Por esta razão, entendeu que a antecipação de parto de feto anencéfalo, a rigor, seria um caso de aborto e que não se poderia invocar o princípio da dignidade da pessoa humana como justificativa para o aborto nesse caso, até porque o nascituro também está protegido pela cláusula constitucional que prevê a dignidade humana (Art. $1^{\circ}$, III da CF).

Dessa forma, como o feto anencéfalo pode nascer com vida, a antecipação do parto seria figura típica. E segundo Gilmar Mendes, o legislador penal ao estabelecer em 1940 as duas hipóteses de aborto permitido, o aborto necessário ou terapêutico em caso de estado de necessidade (em que a vida e saúde física da mãe preponderam); e em caso de estupro, em que se tutela a saúde psíquica da mulher, deixando-se, apesar da viabilidade do feto, a escolha à gestante, teria estabelecido o norte interpretativo para as excludentes: o estado de necessidade; e a inexigibilidade de conduta diversa.

O caso de gestação de feto anencéfalo, para o Ministro, não teria, rigorosamente, analogia com as hipóteses de aborto permitido, uma vez que, quanto à primeira, embora a gestação de feto anencéfalo trouxesse riscos adicionais e consideráveis à mulher, esses riscos não atingiriam a gravidade referida no Art. 128 , I do $\mathrm{CP}$ - que trata de risco de morte, não se subsumindo a este tipo permissivo.

No que diz respeito aos danos psíquicos à mulher em caso de gestação de feto anencéfalo, o Ministro reconheceu uma estrutura lógica semelhante ao Art. 128, II do CP, mas entendeu haver uma distinção relevante de que, neste caso o feto é saudável e, no caso de anencéfalo, embora entenda estar vivo, não lhe reconhece potencialidade de sobrevida.

No entanto, embora não reconheça que a antecipação de parto nos casos de gravidez de anencéfalo se subsuma às excludentes do Art. 128 do CP, o Ministro Gilmar Mendes salienta que a lei não pode ficar inflexível e presa à sua gênese, podendo o juiz adaptar a lei aos novos aspectos da evolução social. Sendo que, no caso, o caminho para que a Corte construísse uma solução legítima poderia ser extraído da própria opção do legislador que expressou valores e bens jurídicos atingidos (art. 128 I e II), tendo efetuado a ponderação.

Assim, embora não se reconheça a primeira hipótese, pois no aborto de anencéfalo há risco à saúde física da mãe, mas não de morte; no entanto, há diagnóstico que gera certeza de 
que feto não sobreviverá mais do que algumas horas, o que implicaria à gestante grave dano psíquico, embora este tampouco se comparasse ao dano no caso de estupro.

Não obstante, o Ministro entende que o aborto de fetos anencéfalos está compreendido entre as cláusulas excludentes de ilicitude (art. 128 do CP), embora sua não inserção expressa devesse-se a omissão legislativa não condizente com o espírito do Código Penal e da Constituição Federal, não sendo, pois, razoável impor à mulher o ônus de levar a cabo a gravidez, o que entende como tortura psíquica e violação à sua livre escolha, por falta de modelo institucional adequado para resolver a questão.

Logo, tal como no direito comparado, o Ministro sugeriu em sua decisão que se impusesse ao Ministério da Saúde o dever de editar normas específicas sobre o diagnóstico de anencefalia e sobre realização de procedimento de antecipação do parto de anencéfalos. Concluindo ser lícito ao STF atualizar o conteúdo normativo do Art. 128 do CP - o que, para ele não implicaria atuação legislativa sobre o tema, em clara divergência ao entendimento do Ministro Ricardo Lewandowski - incluindo nas hipóteses do Art. 128 do CP, portanto como uma terceira hipótese, a anencefalia do feto, julgando procedente a ADPF para dar ao conjunto normativo do Código Penal interpretação conforme a Constituição com efeitos aditivos.

\subsection{Voto do Ministro Celso de Mello}

Em seu voto, o Ministro Celso de Mello, que considera o caso como um dos mais emblemáticos do STF, invoca a jurisprudência internacional, o direito comparado, a doutrina pátria e normas de Direito Internacional relativas a direitos humanos como fundamentação para sua decisão de procedência da ADPF.

O Ministro parte da premissa de que o feto anencéfalo não tem vida e, por conseguinte, não haveria justificativa para se sacrificar direitos fundamentais da dignidade, liberdade e saúde da gestante. Assim, entende Celso de Mello que a antecipação terapêutica de parto de feto anencéfalo não se subsume ao conceito normativo de aborto e, ainda que se entendesse diversamente, haveria exclusão de tipicidade penal ou inexigibilidade de conduta diversa, excluindo-se aqui a culpabilidade.

A não subsunção também decorreria do fato de que, não tendo vida, haveria impropriedade absoluta do objeto sobre o qual incide a ação, até mesmo em razão da Resolução no 1752 do Conselho Federal de Medicina que considera o anencéfalo "natimorto 
cerebral", sem viabilidade e autonomia existencial em ambiente extrauterino, o que implicaria atipicidade penal da conduta da gestante e de quem a auxiliasse nesse procedimento de antecipação terapêutica de parto. Assim, seria inadequado o uso da terminologia "aborto" para interrupção de gravidez de anencéfalo, pois neste caso o feto não teria potencialidade de vida.

Ainda, segundo o Ministro, embora a Constituição Federal salvaguarde o direito à vida, não há um estabelecimento acerca de seu início, valendo, por conseguinte, o raciocínio $a$ contrario em relação à definição do momento da morte pelo Art. $3^{\circ}$ da Lei de 9.434/1997, como sendo o momento de morte encefálica, o que levaria à inferência de que a atividade cerebral seria o marco definidor do início da vida e tal atividade não seria presente em anencéfalos, conforme alguns dos pesquisadores manifestaram em audiência.

Do que concluiu que, sem atividade cerebral, os anencéfalos não seriam considerados pessoas e, por conseguinte, a antecipação terapêutica do parto não seria ofensa ao dever de proteção do Estado na defesa dos direitos da pessoa humana.

Dessa forma, Celso de Mello decidiu na esteira do Ministro Relator pela procedência da ADPF $n^{\circ}$ 54-8/DF, julgando inconstitucional a interpretação que viesse a obstar a antecipação terapêutica de parto de anencéfalos, e, tal como o Ministro Gilmar Mendes, sugeriu a solicitação ao Ministério da Saúde de adoção de medidas e de regulamentação para viabilizar a adoção desse procedimento.

\subsection{Voto do Ministro Cezar Peluso}

O Ministro Cezar Peluso posicionou-se em sentido diametralmente oposto à quase unanimidade de seus pares, por entender que o feto anencéfalo teria vida e, portanto, que a antecipação terapêutica do parto nesse caso seria mero eufemismo para conduta típica que se subsume ao crime de aborto previsto no Art. 124 do CP.

O Ministro Peluso partiu da premissa de que o feto anencéfalo tem vida, até porque, segundo afirmou, se assim não fosse, não se poderia falar de sua morte intra ou extrauterina, tendo afastado o raciocínio a contrario no sentido de se determinar que, se o conceito de morte é de ausência de atividade cerebral (Art. $3^{\circ}$ da lei 9.434/1997) e que o anencéfalo não tem atividade cerebral, não teria, portanto, vida, até mesmo pelas divergências constadas nas audiências públicas em que foram relatados resultados contraditórios acerca da atividade cerebral de anencéfalos, como já apontado. 
Segundo Peluso, os princípios da autonomia da vontade, liberdade pessoal e autodeterminação da mãe não poderiam ser invocados para legitimar uma prática considerada criminosa, entendendo que a antecipação terapêutica de parto é penalmente típica, de modo que o apelo à liberdade e autonomia pessoais seria classificado por ele como "esforço retórico" fundado em presunção errada de falta de proteção da conduta, no intuito de se impor ao feto anencefálico pena de morte, posto que este teria vida e pertenceria à espécie humana, não podendo ser considerado criatura teratológica ou ser a "meio caminho do humano" como sugerira o Ministro Ayres Britto.

Assim, sendo caso de conduta típica, entendeu Peluso que o STF não teria competência para abolir ou excepcionar o caso, já que a eliminação de vida intrauterina seria aborto. Nesse sentido, o Ministro fez analogia ao exemplificar a hipótese de o feto anencéfalo nascer e ter sobrevida, questionando se matá-lo nesse caso não seria infanticídio e que, pela mesma razão, a antecipação do parto seria crime de aborto. Portanto, se o anencéfalo nascido fosse vítima de agressão, haveria crime (infanticídio, homicídio, lesão corporal), não se poderia deixar de considerar a antecipação do parto como crime de aborto.

Ainda argumentou que o feto anencefálico era sujeito de direito e que a alegação da dignidade ou sofrimento da mãe para a antecipação do parto seria mecanismo para transformar o feto em coisa. O Ministro também manifestou preocupação no sentido de que o mesmo raciocínio que levaria à permissão de antecipação de parto de anencéfalo - de evitar o sofrimento da mãe dada a morte certa do feto - pudesse respaldar a defesa de eutanásia de doentes com enfermidade degenerativa que causasse sofrimento a muitas pessoas, a despeito de ser conduta típica (Art. 122 do CP).

Segundo o Ministro, tampouco o argumento de curta potencialidade de vida seria razão para obstar-lhe a continuidade, até porque a vida poderia ser reduzida em muitas outras hipóteses, como no caso de doenças fatais incuráveis, em que a antecipação terapêutica de morte tampouco é autorizada. Também traçou semelhança entre o aborto de anencéfalo e a prática eugênica, uma vez que em seu entender, se julgada procedente a ADPF $n^{\circ} 54-8 / D F$, outras mulheres pleiteariam a mesma medida para demais anomalias de igual gravidade sob o argumento de insuportabilidade da gestação e outros como dignidade e liberdade.

Ao citar o caso Marcela, já referido, o Ministro concluiu, com base nos dados divergentes das audiências públicas, não haver a possibilidade de diagnóstico que diferenciasse anencefalia de outras patologias de gravidade semelhante, sendo, por conseguinte, controverso o próprio conceito de anencefalia e dotado de nuanças, ou seja, formas mais ou menos graves, embora nem todos os cientistas aceitassem essa variabilidade. 
O Ministro Cezar Peluso, então, encaminhou seu argumento no sentido de que a dor da mãe e sua liberdade de escolha não seriam razões para se autorizar o aborto de anencéfalo, já que a antecipação terapêutica do parto é entendida como expressão eufemística para o crime de aborto. E, acrescentou que não se poderia falar em tortura, pois esta se dá quando há sofrimento injusto e inconstitucional, o que não ocorreria no caso, já que as normas penais seriam claras e constitucionais.

Ainda, o Ministro considerou que a gestação de anencéfalo é situação muito diferente do caso de estupro em que haveria tal tipo de sofrimento em razão da ação violenta e ilícita de que resultaria a concepção, em situação diversa da gravidez intencional ou fortuita resultante de sua liberdade sexual. Assim, o Ministro afastou qualquer analogia entre o caso de aborto permitido em hipótese de estupro e aborto de anencéfalo.

Igualmente, afastou a aplicabilidade da hipótese de aborto terapêutico ao caso, posto que considerou que o argumento de que a gestação de anencéfalo seria perigosa para a mãe não viria ao caso, pois se fosse essa a razão para a interrupção da gestação já estaria subsumida no art. 128, I do CP, não se justificando a hipótese no caso de dano psíquico e não real risco de morte.

Na linha do Ministro Lewandowski, o Ministro Peluso reiterou o argumento de que apenas o legislador poderia excluir a punibilidade e que seria impossível a aplicação analógica de interpretação extensiva de normas excludentes de punibilidade, até porque tampouco o Congresso Nacional reconhecera a atipicidade da conduta no caso de interrupção de gravidez de feto anencéfalo.

Por tal razão, o Ministro Cezar Peluso, julgou totalmente improcedente a demanda, entendendo que a antecipação terapêutica do parto de feto anencéfalo constituiria crime, subsumindo-se à conduta tipificada nos dispositivos penais cuja aplicação ao caso a arguente pretendia afastar.

\subsubsection{Aplicação dos métodos e modelos}

\subsubsection{Aplicação do método da subsunção}

Conforme ensinam Alchourrón e Bulygin, a sistematização facilita a obtenção do status deôntico das ações, ou seja, é meio facilitador na busca das soluções normativas para as condutas, se permitidas ou proibidas. Segundo os autores, o âmbito normativo do problema é 
definido pela conjunção do universo do discurso (UD), as circunstâncias, e o universo de ações (UA).

No caso da ADPF no 54-8/DF, o UD é a hipótese de se realizar aborto em caso de anencefalia do feto; o UA $=[\mathrm{A}]$ (o universo de ações diz respeito à ação de abortar). $\mathrm{O}$ universo de propriedades relevantes para o caso é definido a partir dos Arts. 124, 126 e 128, I e II do CP. O aborto é, como regra, vedado em quaisquer casos à luz do disposto no Art. 124 do $\mathrm{CP}$, in verbis: "Provocar aborto em si mesma ou consentir que outrem lho provoque: Pena - detenção, de um a três anos".

Não obstante, o legislador penal excepcionou a hipótese do tipo em duas situações: no caso de risco de morte da mãe e em caso de estupro, caso este em que, por política legislativa, entendeu-se que seria facultada à mãe a decisão de levar ou não a termo a gestação, em razão da gravosa afetação de sua dignidade por ser a gestação fruto de violência sexual. No primeiro caso, justifica-se a opção legislativa, pois há um conflito entre a vida do feto e a vida da mãe, tendo o legislador optado pela última. Em ambos os casos, contudo, é obrigatória a realização do parto por médico.

A partir desses dispositivos, podem-se extrair para o caso quatro propriedades relevantes à luz do ordenamento jurídico: a realização por médico $(\mathrm{m})$; a existência ou não de risco de morte da mãe (r); o consentimento da gestante (c); a ocorrência ou não de estupro (e). Tendo-se em vista a fórmula $2^{\mathrm{n}}$ que permite definir o número de casos do universo de casos, sendo ' $n$ ' o número de propriedades relevantes, tem-se no caso $2^{4}$ (16) casos, segundo a presença (indicada por +) ou ausência (indicada por -) das propriedades relevantes:

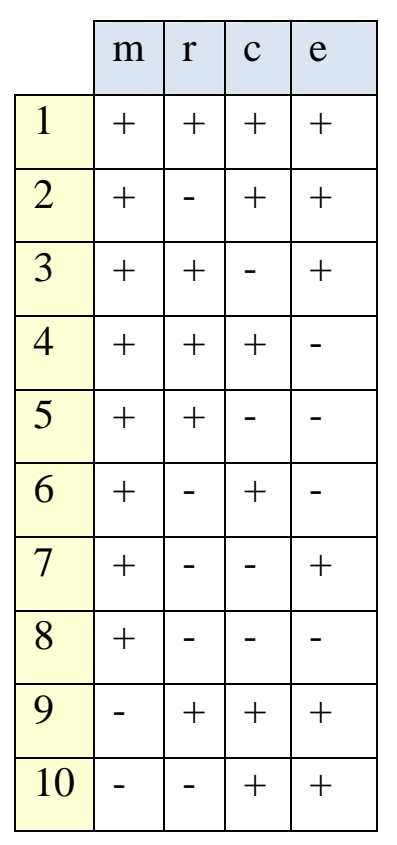




\begin{tabular}{|l|l|l|l|l|}
\hline 11 & - & + & - & + \\
\hline 12 & - & + & + & - \\
\hline 13 & - & - & + & - \\
\hline 14 & - & - & - & + \\
\hline 15 & - & + & - & - \\
\hline 16 & - & - & - & - \\
\hline
\end{tabular}

A partir da constatação da presença ou ausência das propriedades relevantes, pode-se extrair do ordenamento jurídico as respectivas soluções deônticas, conforme os dispositivos acima indicados, o que implica a seguinte sistematização:

\begin{tabular}{|l|l|l|l|l|l|}
\cline { 2 - 6 } \multicolumn{1}{l|}{} & $\mathrm{m}$ & $\mathrm{r}$ & $\mathrm{c}$ & $\mathrm{e}$ & $\mathrm{SN}$ \\
\hline 1 & + & + & + & + & $\mathrm{Pa}$ \\
\hline 2 & + & - & + & + & $\mathrm{Pa}$ \\
\hline 3 & + & + & - & + & $\mathrm{Pa}$ \\
\hline 4 & + & + & + & - & $\mathrm{Pa}$ \\
\hline 5 & + & + & - & - & $\mathrm{Pa}$ \\
\hline 6 & + & - & + & - & $\mathrm{Pha}$ \\
\hline 7 & + & - & - & + & Pha \\
\hline 8 & + & - & - & - & Pha \\
\hline 9 & - & + & + & + & Pha \\
\hline 10 & - & - & + & + & Pha \\
\hline 11 & - & + & - & + & Pha \\
\hline 12 & - & + & + & - & Pha \\
\hline 13 & - & - & + & - & Pha \\
\hline 14 & - & - & - & + & Pha \\
\hline 15 & - & + & - & - & Pha \\
\hline 16 & - & - & - & - & Pha \\
\hline
\end{tabular}

A tarefa da subsunção resume-se, assim, a encontrar a linha da matriz na qual se enquadra o caso, cuja solução estará predeterminada. Em todas as situações em que o aborto não é praticado por médico, será vedado (proibido abortar - Pha), uma vez que é pressuposto 
da realização de aborto nas hipóteses permissivas do Art. 128 do CP, a realização do aborto por médico. Portanto, a propriedade médico (m) é pressuposta, podendo-se mesmo desconsiderar os casos em que ela não esteja presente, pois serão todos proibidos.

Quanto às demais propriedades, caso esteja presente uma ou outra propriedade relevante (conforme já apontado no item 2.2.5) - portanto, trata-se de interpretação disjuntiva $(\mathrm{r} \vee \mathrm{e})$, até por ser irrazoável que uma mãe que corra risco de morte somente possa decidir pelo aborto caso a gestação seja fruto de estupro, ou se tivesse sofrido violência sexual, que só poderá fazer a opção caso a gestação lhe gere risco de morte.

No caso de anencefalia do feto, haveria duas questões a se atentar. A primeira é quanto à sua relevância como propriedade. Para os que entenderam que não se trata de hipótese relevante para a realização de aborto, ela não altera as soluções do sistema normativo acima exposto.

Tal foi a orientação do voto do Ministro Cezar Peluso, para o qual o feto anencefálico é vivo como qualquer outro e a baixa potencialidade de sobrevida não seria justificativa para o aborto, que se configuraria no caso. A solução adotada pelo Ministro fora, portanto, pela subsunção do caso ao tipo penal incriminador dos Arts. 124 e 126 do CP. Isso, porque, não configuradas as hipóteses excludentes, também no caso de aborto de anencéfalo, seria vedada a prática de aborto, ou, caso configuradas, haveria subsunção às normas permissivas (art. 128, I e II do CP), sem qualquer relação com o fato de o feto ser anencéfalo.

Já os que admitem a anencefalia como propriedade relevante - e a relevância dá-se pelo fato de a presença ou ausência da propriedade alterar o resultado, ou a solução deôntica chegam ao que o Ministro Gilmar Mendes chama de interpretação com efeitos aditivos. Isso, porque, altera-se o sistema normativo originário, culminando na seguinte sistematização presumindo-se apenas as hipóteses em que o médico $(\mathrm{m})$ esteja presente, já que na ausência, o aborto será proibido - além das outras quatro propriedades relevantes: risco de morte (r), estupro (e) e anencefalia do feto $(f)$. Portanto, do total de trinta e dois casos $\left(2^{5}\right)$, tendo-se em vista as cinco propriedades relevantes, serão desconsiderados os dezesseis em que o médico estiver ausente, em que o aborto será proibido, mantendo-se os casos em que o médico está presente: 


\begin{tabular}{|ll|l|l|l|l|l|l|}
\cline { 2 - 6 } \multicolumn{1}{l|}{} & $\mathrm{m}$ & $\mathrm{r}$ & $\mathrm{e}$ & $\mathrm{c}$ & $f$ & $\mathrm{SN}$ \\
\hline 1 & + & + & + & + & + & $\mathrm{Pa}$ \\
\hline 2 & + & + & + & + & - & $\mathrm{Pa}$ \\
\hline 3 & + & + & + & - & + & $\mathrm{Pa}$ \\
\hline 4 & + & + & - & + & + & $\mathrm{Pa}$ \\
\hline 5 & + & - & + & + & + & $\mathrm{Pa}$ \\
\hline 6 & + & + & + & - & - & $\mathrm{Pa}$ \\
\hline 7 & + & + & - & - & + & $\mathrm{Pa}$ \\
\hline 8 & + & - & - & + & + & $\mathrm{Pa}$ \\
\hline 9 & + & - & + & - & + & $\mathrm{Pha}$ \\
\hline 10 & + & + & - & + & - & $\mathrm{Pa}$ \\
\hline 11 & + & - & + & + & - & $\mathrm{Pa}$ \\
\hline 12 & + & + & - & - & - & $\mathrm{Pa}$ \\
\hline 13 & + & - & + & - & - & $\mathrm{Pha}$ \\
\hline 14 & + & - & - & + & - & $\mathrm{Pha}$ \\
\hline 15 & + & - & - & - & + & $\mathrm{Pha}$ \\
\hline 16 & + & - & - & - & - & $\mathrm{Pha}$ \\
\hline
\end{tabular}

Neste caso, se houver risco de morte ou estupro ou anencefalia - nas duas últimas situações, com o consentimento da mãe - , o aborto será permitido $(\mathrm{Pa} \rightarrow \mathrm{m} \Lambda \mathrm{r} v[(\mathrm{e} \vee f) \Lambda \mathrm{c}]$. Portanto, também no caso em que apenas a anencefalia estivesse presente, sem que a gestação fosse resultado de estupro ou implicasse risco de morte à mãe, seria permitido o aborto se a mãe consentisse.

Isso implicaria uma terceira excludente de ilicitude (não prevista expressamente nos incisos do Art. 128 do CP), o que, inclusive, foi fator de críticas de alguns dos Ministros, em especial, do Ministro Ricardo Lewandowski, apontando a solução como ativismo judicial, visto que o Judiciário estaria usurpando função estritamente legislativa e mudando o ordenamento jurídico.

Ainda, o reconhecimento da anencefalia do feto como propriedade relevante, poderia levar à solução simplesmente pela não subsunção ao art. 124 do $\mathrm{CP}$, sob a justificativa de que a norma proibitiva pressupõe a vida do feto e, no caso do anencéfalo, não haveria vida. Quanto a essa hipótese, a argumentação levada a cabo pelos Ministros que assim entenderam 
não foi relativa à vida intrauterina, admitida por todos, ainda que considerada meramente vegetativa, mas tendo como norte orientador dos que entenderam pela não subsunção ao Art. 124 do CP a inexistência de potencialidade de vida extrauterina ${ }^{255}$.

Portanto, mesmo a solução por subsunção admitiria, e este foi o caso, dupla e antitética solução: pela subsunção ou pela não subsunção ao tipo penal incriminador ou aos tipos penais permissivos. E isso decorre da diferente construção da premissa normativa pelos diferentes Ministros por meio de processos interpretativos, o que corrobora o anteriormente apontado de que a subsunção não se trata de processo meramente mecânico e tampouco leva a resultados tão certos e seguros como pretendido.

\subsubsection{Aplicação do método da ponderação}

Embora o conflito entre o princípio da vida do feto e o princípio da dignidade da mulher esteja presente, fora obscurecido pela retórica dos votos de alguns Ministros. O Ministro Relator, Marco Aurélio, cujo voto embasou o julgamento, visto ter sido seguido pela maioria dos Ministros da Corte, desconheceu o conflito de princípio, porque entendeu que no caso só havia a dignidade da mulher e não o direito à vida do feto, posto que o feto anencefálico não teria, para ele, vida. No mesmo sentido foi o entendimento dos Ministros Celso de Mello, Carlos Ayres Britto, Rosa Maria Weber, Carmen Lucia e Luiz Fux que se orientaram conforme o entendimento do Relator, pela impossibilidade de vida no caso de feto anencéfalo e, portanto, com desconhecimento de real conflito de princípios no caso.

Tampouco o Ministro Cezar Peluso reconheceu o conflito de princípios, mas em sentido diametralmente oposto ao do Relator, pois Peluso entendeu que no caso apenas havia de se tutelar a vida do feto, já que a manutenção da gestação de feto anencéfalo não constituiria ofensa à dignidade da mulher, desconhecendo tal princípio no caso e resolvendo-o por subsunção à norma penal incriminadora.

Já o Ministro Ricardo Lewandowski, embora também tenha apontado o conflito entre direito à vida do nascituro e o direito à vida e à saúde da gestante, pauta seu voto na solução do caso pela subsunção do fato à norma tipificadora do Art. 124 do CP.

O Ministro Joaquim Barbosa em corroboração de seu voto exarado no HC no 84.0256/RJ reconheceu o conflito de princípios, embora tenha partido da premissa de que a vida do anencéfalo é meramente orgânica, tendo excluído a subsunção da hipótese ao tipo penal

\footnotetext{
${ }^{255} \mathrm{Na}$ verdade, há divergência, mas trata-se de entendimento majoritário da doutrina penal.
} 
incriminador constante do conjunto normativo dos Arts. 124, 126 e 128, I e II do CP, cuja tutela seria voltada, de um lado, à preservação de uma vida potencial e, por outro lado, à incolumidade da gestação. A não subsunção seria em razão de o Ministro entender que haveria impossibilidade de sobrevida do feto anencéfalo fora do útero materno.

No que concerne ao conflito de princípios, urge a reconstrução de seus argumentos, a fim de se notar quais os princípios por ele reconhecidos como em colisão e de que maneira levou a cabo a ponderação, embora de modo não explícito, fazendo-se, pois, aqui, inferências estipulativas.

O Ministro Joaquim Barbosa embora tenha admitindo o direito à vida em sentido amplo do feto e sua contraposição com a liberdade e a autonomia privada da mulher, concluiu em seu voto que haveria prevalência da dignidade da gestante, que seria atingida caso se a privasse de seu direito de escolha. Depreende-se, assim, que o Ministro ponderou entre a vida do feto anencéfalo e a liberdade da mãe de escolher entre fazer ou não a antecipação do parto, com prevalência da última.

No que concerne ao peso atribuído à vida do anencéfalo, considerando-a apenas como vida biológica e mediante sua distinção entre: feto em pleno desenvolvimento, biologicamente morto e biologicamente vivo, mas juridicamente morto; inserindo o caso de feto anencéfalo na última hipótese, para o fim de excluir a tutela do Direito Penal e, portanto, afastar a subsunção, entende-se que o peso que atribuiu a essa vida é considerado como moderado ou leve.

Tanto assim que o Ministro explicita que, ao cominar penas diversas nos tipos penais que visam à tutela da vida em diferentes momentos: antes do nascimento (crime de aborto), após o nascimento (crime de infanticídio) e na vida adulta (crime de homicídio), o legislador penal teria atribuído pesos diferentes à vida consoante seu estádio de desenvolvimento.

Também ao pontuar que, se nas hipóteses de exclusão de ilicitude (Art. 128, I e II do $\mathrm{CP}$ ) o legislador deu maior peso a princípios outros que não a vida do feto, quando este tinha plena potencialidade de vida extrauterina, não seria, por conseguinte, coerente que na hipótese de anencefalia do feto, em que o Ministro desconhecia tal potencialidade, a solução jurídica fosse diversa, no sentido de dar preponderância à vida do feto, tendo sinalizado atribuição de peso leve a esta.

No que diz respeito à liberdade de escolha da gestante, segundo o Ministro Joaquim Barbosa, haveria desproporcionalidade se lhe fosse interditado o exercício desse direito, quando em outras circunstâncias em que o feto tem potencialidade de vida extrauterina, nas 
excludentes referidas, o legislador lhe tutelara a autonomia privada de escolher entre manter ou interromper a gravidez.

Por isso, orientou-se no sentido de que a concessão da ordem de habeas corpus para o fim de permitir a antecipação do parto no caso de anencefalia do feto seria medida adequada ao fim de salvaguardar a dignidade da mulher, mais propriamente sua liberdade, visto que considerou que a obrigatoriedade imposta à gestante de manutenção de gestação de feto que se sabe que morreria implicaria grave violação à sua autonomia decisória.

Quanto à necessidade de tal medida, entende-se que o Ministrou considerou-a necessária, pois a sua não concessão implicaria a possibilidade de criminalização da conduta da gestante que viesse a exercer sua liberdade, escolhendo a interrupção da gestação de feto anencéfalo, como crime de aborto, tal como no entendimento de diversos juízos de primeira instância e de tribunais. Portanto, a medida seria necessária para se salvaguardar a liberdade de escolha da mulher, pois doutra sorte, ela não poderia escolher, estando obrigada a levar a termo a gestação.

Assim, em uma ponderação em sentido estrito, Joaquim Barbosa teria considerado alta ou grave a importância de se satisfazer o princípio da liberdade, afetado pela vedação à antecipação de parto de feto anencéfalo, e leve ou baixa a importância de se satisfazer no caso o princípio da vida, visto que entendeu a vida do anencéfalo como orgânica apenas e de menor peso que a vida de um nascituro com potencialidade de sobrevida extrauterina.

Reconstruindo-se idealmente a ponderação que se revela nos argumentos, presume-se que para Joaquim Barbosa a intervenção na liberdade $(l)$ da mulher seria considerada como grave $\left(\operatorname{IdC}^{256}=4\right)$ e o peso abstrato da liberdade considerado como sério $(\mathrm{WdA}=4)$, havendo certeza quanto à sua afetação, em caso de proibição de sua escolha pela interrupção ou não de gestação de feto anencéfalo $(\mathrm{SdC}=1)$.

Quanto ao princípio do direito à vida do feto anencéfalo, tendo-se em vista que o Ministro considerou que este tem apenas vida orgânica, infere-se que, em sua opinião, a intervenção na vida $(v)$ seria considerada como leve $(\operatorname{IdC}=1)$ e o peso abstrato da vida considerado como sério $(\mathrm{WdA}=4)$, embora concretamente no caso de anencéfalo fosse considerado como leve. E quanto à afetação à vida do feto em caso de permissão de antecipação do parto, seria não evidentemente falsa $(\mathrm{SdC}=0,25)$. Transpondo-se tais pesos para a fórmula de peso, ter-se-ia o seguinte resultado:

\footnotetext{
${ }^{256}$ Relembre-se que a intervenção em um princípio e a certeza de sua afetação são aferidas concretamente, daí o $\mathrm{C}$ das fórmulas ( $\mathrm{PdC}$ e $\mathrm{SdC}$ ), diferentemente do peso que entra na fórmula - que é abstrato (A), $\mathrm{WdA}$ - para se chegar ao peso concreto de um princípio em relação ao outro.
} 


$$
\mathrm{GP} l, \mathrm{vC}=\underset{\mathrm{WPvC} \cdot \mathrm{WPvA} \cdot \mathrm{SPvC}}{=\mathrm{WC} \cdot \mathrm{WP} l \mathrm{~A} . \mathrm{SP} l \mathrm{C}}=\mathrm{GP} l, \mathrm{vC}=\frac{4 \times 4 \times 1}{1 \times 4 \times 0,25}=\frac{16}{1}=16 .
$$

Tendo-se em vista que o valor alcançado é maior do que um, o peso concreto da liberdade da gestante prevalece em relação à vida do feto anencéfalo e a disparidade no resultado obtido (16/1) seria denotativo da significativa consideração à liberdade da gestante e à pequena consideração à vida do feto anencéfalo, tida como orgânica e destituída de potencialidade de sobrevida, consoante o voto do Ministro Joaquim Barbosa.

Também reconhece o conflito, a despeito da aparente obscuridade em seu voto, posto que inicialmente o Ministro Gilmar Mendes manifesta-se pela subsunção ao tipo penal incriminador da antecipação terapêutica do parto em caso de anencefalia do feto, uma vez que parte da premissa da existência de vida deste, especialmente por considerar que, se o feto anencéfalo pode nascer com vida, tem vida e também dignidade.

No entanto, na sequência de seu voto, cogita da inclusão da hipótese nas excludentes do Art. 128, I e II do CP, afastando a hipótese de subsunção ao inciso I, pois considera que embora a gestação de feto anencéfalo possa aumentar os riscos à saúde da mãe não chega à gravidade de implicar risco de morte da gestante.

E também afasta a subsunção ao inciso II do Art. 128 do CP, já que entende que, se na excludente o legislador penal ponderou entre a vida do feto e a dignidade da mãe, a afetação desta no caso de estupro seria substancialmente maior do que no caso de anencefalia do feto, até porque este também teria dignidade a ser tutelada.

Não obstante, o Ministro prosseguiu no entendimento de que, embora o caso não se subsumisse às excludentes de ilicitude, também não se subsumiria ao Art. 124 do $\mathrm{CP}$, de modo que se enquadraria em uma terceira hipótese excludente não expressa pelo legislador. Isso porque, a despeito de entender que o feto anencéfalo tem vida, este não teria potencialidade de sobrevida e, por outro lado, a obrigatoriedade de se manter a gestação de um feto que se sabe que morreria implicaria tortura psíquica à mãe e ofensa à sua liberdade de optar entre levar ou não a termo a gravidez.

A partir desses argumentos, embora seja difícil se aferir qual o conflito efetivamente reconhecido, se entre a vida do feto e a dignidade da mãe ou entre a vida do feto e a liberdade da mãe, entende-se que seria este o conflito reconhecido pelo Ministro Gilmar Mendes, uma vez que afastou a real incidência de conflito com a dignidade, pois, embora esta fosse reconhecida, não seria de tal peso a justificar sua prevalência sobre a vida do feto, tal como ponderara o legislador penal na excludente do Art. 128, II do CP. 
Ademais, fora justamente o reconhecimento do peso da liberdade de escolha da gestante o que levou o Ministro a proferir uma decisão com efeitos aditivos sugerindo a hipótese de anencefalia como terceira excludente de ilicitude. De modo que se infere de seu voto o reconhecimento do conflito entre o direito à vida do feto, com peso moderado, dada a consideração da falta de potencialidade de sua sobrevida e, por outro lado, o direito à liberdade de escolha da gestante, com peso considerado como alto, uma vez que a obrigatoriedade de dar prosseguimento à gestação poderia ser considerada como tortura psicológica em sua opinião.

Assim, deflui dos argumentos do Ministro Gilmar Mendes que a procedência da ADPF $n^{\circ}$ 54-8/DF, permitindo-se a antecipação do parto de feto anencéfalo seria considerada medida adequada para a tutela da liberdade de escolha da mãe e seria igualmente medida necessária, tendo em vista a citada possibilidade de criminalização dessa conduta em caso de decisão em sentido diverso.

No concernente à ponderação em sentido estrito, infere-se que o Ministro adotou posicionamento semelhante ao do Ministro Joaquim Barbosa, com pequenas variações. Para Gilmar Mendes a intervenção na liberdade $(l)$ da mulher seria considerada como grave (IdC = 4) e o peso abstrato da liberdade considerado como sério $(\mathrm{WdA}=4)$, havendo certeza quanto à sua afetação, em caso de proibição de sua escolha pela interrupção ou não de gestação de feto anencéfalo $(\mathrm{SdC}=1)$.

Quanto ao princípio do direito à vida do feto anencéfalo, fora reconhecida, embora não equiparada à de um feto referido pelo Ministro como saudável, o que implicaria que a intervenção na vida $(v)$ seria considerada como moderada $(\mathrm{IdC}=2)$ e o peso abstrato da vida considerado como sério $(\mathrm{WdA}=4)$. E quanto à afetação à vida do feto em caso de permissão de antecipação do parto, seria plausível $(\mathrm{SdC}=0,5)$. A partir desses pesos presumidos, obterse-ia o seguinte resultado:

$$
\mathrm{GP} l, \mathrm{vC}=\frac{\mathrm{IP} l \mathrm{C} \cdot \mathrm{WP} l \mathrm{~A} \cdot \mathrm{SP} l \mathrm{C}}{\mathrm{WPvC} \cdot \mathrm{WPvA} \cdot \mathrm{SPvC}}=\mathrm{GP} l, \mathrm{vC}=\frac{4 \times 4 \times 1}{2 \times 4 \times 0,5}=\underline{16}=4 .
$$

Tanto quanto o Ministro Joaquim Barbosa, entende o Ministro Gilmar Mendes que no caso de anencefalia do feto prevalece a liberdade da mãe em relação à vida do feto, muito embora os resultados denotem que o peso atribuído à vida do feto fora maior no caso de Ministro Gilmar Mendes, até por sua cogitação inicial pela subsunção ao tipo penal, 
desenvolvendo ao longo de seu argumento a hipótese de terceira excludente, pela prevalência concreta da liberdade da gestante sobre a vida do feto anencéfalo.

Não obstante, estes votos não correspondem ao julgamento efetivo da Corte levado a cabo em outras bases, sob a presunção de inexistência de vida do feto anencéfalo. A razoabilidade dessa decisão, o que não se confunde com a defesa sobre sua correção, poderia ser aferida pela aplicação do modelo coerentista.

\subsubsection{Aplicação do Modelo Coerentista}

A aplicação do modelo coerentista ao caso do aborto de anencéfalos fora já realizada por Juliano Maranhão ao analisar a decisão do Ministro Relator Marco Aurélio Mello, em sede de medida liminar, no ano de 2004. E, tendo-se em vista que no julgamento final, o Ministro Relator manteve integralmente seu posicionamento, corroborando a decisão anteriormente prolatada, pode-se aqui considerar a aplicação já efetuada.

Como já anteriormente exposto, o sistema normativo resultante da interpretação do Código Penal leva à proibição de aborto em caso de anencefalia do feto, visto que tal hipótese não está prevista nas excludentes de ilicitude do Código Penal (art. 128 e incisos do CP), salvo o caso de se considerar que, no anencéfalo não há de se falar em vida e, neste caso, estaria descaracterizado o crime de aborto.

Não obstante, chama a atenção o voto prolatado pelo Ministro Relator, corroborado por diversos outros julgadores, posto que não postulou mero caso de não subsunção ao tipo penal incriminador, mas considerou a anencefalia do feto como um fator relevante que implicava a permissão de aborto, a despeito do sistema extraído do Código Penal, em que a anencefalia não era fator relevante e não alterava a solução normativa que proibia o aborto. Contudo, como explica Juliano Maranhão ${ }^{257}$ :

O ponto é que, quando a questão foca sobre a anencefalia, Dign>Vfeto [dignidade da mãe prevalecente em relação à vida do feto] perde poder explicativo para uma possível especificação de sentido para o art. 124 do CPB [Código Penal brasileiro]. Aparecem então duas interpretações para os arts. 124 e 128 do CPB:

$\mathrm{K} \alpha$ : seu conteúdo é fixado como $124^{* * *}$, ao lado de $128^{*}$ ("é permitido o aborto nas hipóteses de risco de vida, estupro e feto anencéfalo"), que é explicado por Dign $>$ Vfeto;

257 MARANHÃO, Juliano Souza de Albuquerque. Inclusivismo Lógico: uma contribuição à metodologia jurídica. Tese de livre-docência, Departamento de Filosofia e Teoria Geral do Direito, Universidade de São Paulo, São Paulo, 2010, p. 188-189. 
$\mathrm{K}_{\beta}$ : seu conteúdo é fixado como $124^{* *}$ e 128 , que pode ser explicado por outro princípio, ou inversão da relação Vfeto>Dign para essa hipótese, ou ainda uma qualificação da relação de preferência Dign>Vfeto (e.g. relação prevalece somente quando o sofrimento independa de enfermidade do feto). Isso significa que não há propriamente um conflito entre norma e princípio, mas conflito entre interpretações dos arts. 124 e 128 como resultado de um ato de legislação racional [...] Na definição de qual seria a melhor expressão da vontade racional do legislador, obviamente a interpretação $K_{\beta}$ que não traz qualificações implícitas tem uma razão forte no sentido de que um legislador suficientemente preciso, teria especificado a exceção se essa fosse sua vontade. Há uma presunção de que a condição expressa seria suficiente. Por outro lado, $\mathrm{K}_{\beta}$ tem que superar a aparente incoerência (imprópria para $o$ pressuposto de racionalidade) de que a dignidade prevaleceria no caso de estupro, mas não no caso de sofrimento pela morte certa do nascituro. Seja qual for o desenlace dessas duas interpretações juridicamente defensáveis, o princípio de dignidade da mulher é uma razão jurídica relevante para a ação de abortar conforme o ordenamento jurídico brasileiro, não por sua moralidade, mas por ter sido claramente endossado nos dispositivos legais.

Ou seja, por meio de uma inferência abdutiva, o autor partiu de regras jurídicas identificando as razões, valores e princípios relevados pelo legislador quando de sua elaboração, razões essas que poderiam ser a melhor hipótese explicativa para a elaboração da regra posta e que poderiam orientar a solução do caso dos anencéfalos tendo-se em vista a razão subjacente às regras já postas e a coerência do sistema jurídico.

Assim, no caso, embora a norma permissiva (Art. 128 e incisos do $\mathrm{CP}$ ) não autorizasse expressamente o aborto em caso de anencefalia, levantou-se o conflito entre a vida do feto e a dignidade da mãe. Ou mais especificamente, porque o Ministro Marco Aurélio não considera que haja vida que mereça tutela, visto não ter o anencéfalo potencialidade de vida, o que seria maior razão para a prevalência da dignidade da mãe $e^{258}$. Como resultado de uma inferência abdutiva, considerou-se que a dignidade da mãe seria a razão subjacente que teria inspirado o legislador penal na elaboração da norma permissiva constante do Art. 128, II do CP.

E, como alerta o autor, no caso da ADPF $n^{\circ} 54-8 / D F$, o Ministro Relator levanta a dignidade humana e a premissa de que suportar uma gravidez com a certeza da morte do nascituro como sofrimento indigno para o ser humano - o que equivaleria a tortura, segundo sua concepção -, como razões para propor a anencefalia do feto $(f)$ como fator relevante para

\footnotetext{
${ }^{258}$ Embora o Ministro Marco Aurélio fale de morte certa do nascituro, o que leva a crer que admita a existência de vida no feto anencéfalo, em outros trechos diz que não há que se falar em vida no caso, ou se há, trata-se de vida apenas vegetativa, destituída do conteúdo humano essencial. O argumento forte do Ministro, contudo, é de que uma vez que a morte do nascituro é certa, o caso não seria de aborto, mas de antecipação do parto, visto que não seria o procedimento que implicaria a morte, mas a própria anencefalia. O fato é que, embora haja certa obscuridade no voto, a posição do Ministro é de que, se no caso de um feto "saudável", o legislador ponderou entre a vida do feto e a dignidade da mãe ofendida por ser a gestação resultante de violência sexual, prevalecendo a dignidade materna (caso do Art. 128, II do CP), com maior razão, no caso de feto anencéfalo, em que não se cogita de vida efetiva, deveria a dignidade da mãe prevalecer.
} 
a permissão do aborto, ainda que ausentes as demais condições (exceto a prática por médico, já que sua ausência implicaria proibição de aborto para qualquer caso, e a necessidade de consentimento que também é mantida também neste caso) constantes do Art. 128 do CP.

Logo, partindo dessa perspectiva, tomando-se a dignidade da mulher como razão subjacente à permissão legal de aborto em caso de gravidez resultante de estupro, prevista na disposição penal permissiva (Art. 128, inciso II do CP), por inferência abdutiva, portanto, potencialmente equívoca, concluiu-se que também em caso de anencefalia do feto a dignidade da mulher seria uma razão que levaria à permissão de aborto, determinando-se a solução para este caso, com vistas a manter a coerência do sistema jurídico.

A inferência pode ser destrinchada em duas matrizes que permitem melhor visualização da aplicação do modelo inferencial e de como ele propicia a vinculação à lei. Como exposto, a permissão do aborto tem por justificativa: i) no caso de risco de morte da mãe, o princípio da vida da mãe (Vmãe); ii) no de estupro, a dignidade da mulher (Dign); iii) a necessidade de consentimento, como implicação do princípio da liberdade da mulher (Lib). A relação entre os princípios está explicitada na seguinte matriz (A) abaixo (as relações entre princípios resultam de inferência abdutiva a partir das colunas de casos e da coluna de soluções):

\begin{tabular}{|c|c|c|c|c|c|}
\cline { 2 - 6 } \multicolumn{1}{c|}{} & r & e & c & Relação de princípios & Solução \\
\hline 1 & + & + & + & Vmãe + Dign + Lib > Vfeto & $\mathrm{Pa}$ \\
\hline 2 & + & + & - & Vmãe + Dign > Vfeto & $\mathrm{Pa}$ \\
\hline 3 & + & - & + & Vmãe + Lib > Vfeto & $\mathrm{Pa}$ \\
\hline 4 & + & - & - & Vmãe $>$ V.feto & $\mathrm{Pa}$ \\
\hline 5 & - & + & + & Dign + Lib $>$ Vfeto & $\mathrm{Pa}$ \\
\hline 6 & - & + & - & Dign $<$ Vfeto & $\mathrm{Pha}$ \\
\hline 7 & - & - & + & Lib $<$ Vfeto & Pha \\
\hline 8 & - & - & - & Não há conflito de princípios & \\
\hline
\end{tabular}

Nessa matriz não se cogita da hipótese de anencefalia do feto. Portanto, são três as propriedades relevantes, resultando em oito casos. Quando se cogita de anencefalia do feto, o aumento no número de propriedades relevantes resulta em maior número de casos (matriz B) abaixo (dessa vez, a coluna de princípios traz o princípio ligado a cada fator relevante e a 
relação de preferência é retirada da coluna de princípios da matriz A; a coluna de soluções é deduzida a partir da relação entre princípios):

\begin{tabular}{|l|c|c|c|c|c|c|}
\cline { 2 - 7 } \multicolumn{1}{c|}{} & r & e & c & $f$ & Relação de princípios & Solução \\
\hline 1 & + & + & + & + & Vmãe + Dign + Lib > Vfeto & $\mathrm{Pa}$ \\
\hline 2 & + & + & - & + & Vmãe + Dign > Vfeto & $\mathrm{Pa}$ \\
\hline 3 & + & - & + & + & Vmãe + Lib + Dign > Vfeto & $\mathrm{Pa}$ \\
\hline 4 & + & - & - & + & Vmãe + Dign $>$ Vfeto & $\mathrm{Pa}$ \\
\hline 5 & - & + & + & + & Dign + Lib $>$ Vfeto & $\mathrm{Pa}$ \\
\hline 6 & - & + & - & + & Dign $<$ Vfeto & $\mathrm{Pha}$ \\
\hline 7 & - & - & + & + & Dign + Lib $>$ Vfeto & $\mathrm{Pa}$ \\
\hline 8 & - & - & - & + & Dign $<$ Vfeto & $\mathrm{Pa}$ \\
\hline 9 & + & + & + & - & Vmãe + Dign + Lib $>$ Vfeto & $\mathrm{Pa}$ \\
\hline 10 & + & + & - & - & Vmãe + Dign $>$ Vfeto & $\mathrm{Pa}$ \\
\hline 11 & + & - & + & - & Vmãe + Lib $>$ Vfeto & $\mathrm{Pa}$ \\
\hline 12 & + & - & - & - & Vmãe $>$ V.feto & $\mathrm{Pa}$ \\
\hline 13 & - & + & + & - & Dign + Lib $>$ Vfeto & $\mathrm{Pha}$ \\
\hline 14 & - & + & - & - & Dign $<$ Vfeto & Lib $<$ Vfeto \\
\hline 15 & - & - & + & - & Não há conflito de princípios & \\
\hline 16 & - & - & - & - & + & + \\
\hline
\end{tabular}

Nota-se que a linha 7 da matriz B contempla a mesma relação de princípios da linha 5 da matriz A; portanto, deveria receber a mesma solução, tal como resultou da decisão prolatada pelo STF. Isso como demonstração na proposta inferencial de Juliano Maranhão de que o modelo coerentista seria meio para justificar as decisões judiciais tomadas tendo-se em vista o Direito posto, sem que houvesse a necessidade de recurso a razões morais como propõem outras linhas coerentistas, tais como a de Peczenik e Dworkin.

Assim, no caso, a decisão prolatada pelo Ministro Marco Aurélio e pelos demais julgadores que o seguiram, teria por respaldo a própria orientação do legislador penal ao dar primazia à dignidade da mãe em relação à vida do nascituro (Art. 128, II do CP). No caso dos anencéfalos, em que não se reconhecia a potencialidade de vida extrauterina, mas sim o sofrimento da mãe, compelida a levar a termo a gestação em violação à sua liberdade e 
dignidade, haveria maior razão para a permissão, consoante decidido, independentemente da correção ou não dessa decisão.

\subsection{CASO ELLWANGER (HC No 82.424-2/RS)}

\subsubsection{Questões preliminares}

\subsubsection{Síntese do caso e colocação do problema semântico preliminar}

O caso Ellwanger é assim denominado por ser paciente do Habeas Corpus (HC) $\mathrm{n}^{\circ}$ 82.424-2/RS ${ }^{259}$, julgado pelo STF em 17.09.2003, Siegfried Ellwanger Castan. Cumpre inicialmente apresentar o histórico do caso e a tese da defesa que enseja o problema semântico preliminar tratado por todos os Ministros, tendo, inclusive, sido o único foco de argumentação de alguns deles.

Embora seja notório o conflito de princípios subjacente, grande parte da discussão versou sobre o aspecto semântico da abrangência do conceito de racismo, para o fim de se definir que tipos de condutas inserem-se no fato típico ao qual se imputou na Constituição Federal (Art. $5^{\circ}$ da CF) imprescritibilidade, revelando, pois, a excepcionalidade constitucional da imputação, fazendo presumir a gravidade desse delito.

O caso começa com a denúncia de Ellwanger em primeira instância no ano de 1991, no Estado do Rio Grande do Sul, pela imputação da prática do crime de racismo tipificado no Art. 20 da Lei $n^{\circ} 7.716 / 89$, com redação dada pela Lei $n^{\circ}$ 8.081/90, em razão da edição e distribuição de obras com conteúdo antissemita de sua autoria e de autoria de terceiros, neste caso, na condição de editor de tais obras.

Ellwanger foi absolvido em primeiro grau e, no recurso interposto pelos assistentes da acusação, perante o Tribunal de Justiça do Rio Grande do Sul (TJRS), foi condenado a dois anos de reclusão com sursis pelo prazo de quatro anos, como incurso no caput do Art. 20 da Lei 7.716/89, por ter tido intuito de "incitar e induzir a discriminação racial” por meio das obras referidas.

\footnotetext{
259 BRASIL. Supremo Tribunal Federal. Habeas Corpus n ${ }^{\circ}$ 82.424-2/RS. Ministro Relator Moreira Alves. Ministro Relator para o Acórdão Maurício Corrêa. Julgado em 17.09.2003. D.J. 19.03.2004. Disponível em: <http://redir.stf.jus.br/paginadorpub/paginador.jsp?docTP=AC\&docID=79052>. Acesso em: 21 out. 2011.
} 
Ante a condenação em grau recursal, Ellwanger impetrou Habeas Corpus no ano de 2000 perante o STJ sob a alegação de que o delito de discriminação contra judeus não teria conotação racial, não sendo, portanto, imprescritível, pois a imprescritibilidade está reservada ao racismo conforme dispõe o Art. $5^{\circ}$, XLII da CF. E, uma vez afastada a imprescritibilidade, dever-se-ia reconhecer a ocorrência da extinção da punibilidade pela prescrição da pretensão punitiva, já que a condenação a dois anos de prisão com sursis deu-se em 31 de outubro de 1996, mais de quatro anos após o recebimento da denúncia.

Por decisão majoritária da quinta turma do STJ, o Habeas Corpus foi denegado, tendo os Ministros daquele tribunal entendido que Ellwanger praticara discriminação contra judeus e que este se trata de caso de discriminação racial, crime imprescritível.

Neste sentido fora o parecer do Subprocurador-Geral da República, Cláudio Lemos Fonteles, opinando pelo indeferimento do pedido por considerar injurídico o argumento de que a Constituição Federal reduz a prática de racismo a raça, defendendo que o Art. $5^{\circ}$, XLII da $\mathrm{CF}$, embora não defina prática de racismo, transferiu a incumbência de fazê-lo à legislação infraconstitucional, o que foi regulamentado pela Lei $n^{\circ} 7.716 / 89^{260}$ que torna as diversas condutas nela descritas crime de racismo, ao qual a Constituição atribuiu imprescritibilidade.

Contra a decisão daquele Corte, impetrou-se o Habeas Corpus sob n ${ }^{\circ}$ 82.424-2/RS, conforme referido, perante o STF, substitutivo de Recurso Extraordinário, tendo-se repetido a tese de que o delito de discriminação contra os judeus não se constitui crime de racismo, sujeitando-se, pois, à observância do prazo prescricional previsto em lei.

Segundo a ementa da Lei $\mathrm{n}^{\circ} 7.716$ de 05 de janeiro de 1989, a lei "define os crimes resultantes de preconceito de raça e cor”. Essa lei foi alterada pela Lei $n^{\circ} 8.081$ de 21 de setembro de 1990 que "estabelece os crimes e as penas aplicáveis aos atos discriminatórios ou de preconceito de raça, cor, religião, etnia ou procedência nacional, praticados pelos meios de comunicação ou por publicação de qualquer natureza", ampliando, portanto, a acepção de discriminação prevista na lei anterior e fazendo inserir o Art. 20 à Lei 7.716/89 dispondo, in verbis: “Art. 20. Praticar, induzir ou incitar, pelos meios de comunicação social ou por publicação de qualquer natureza, a discriminação ou preconceito de raça, por religião, etnia ou procedência nacional. Pena: reclusão de dois a cinco anos" ${ }^{261}$.

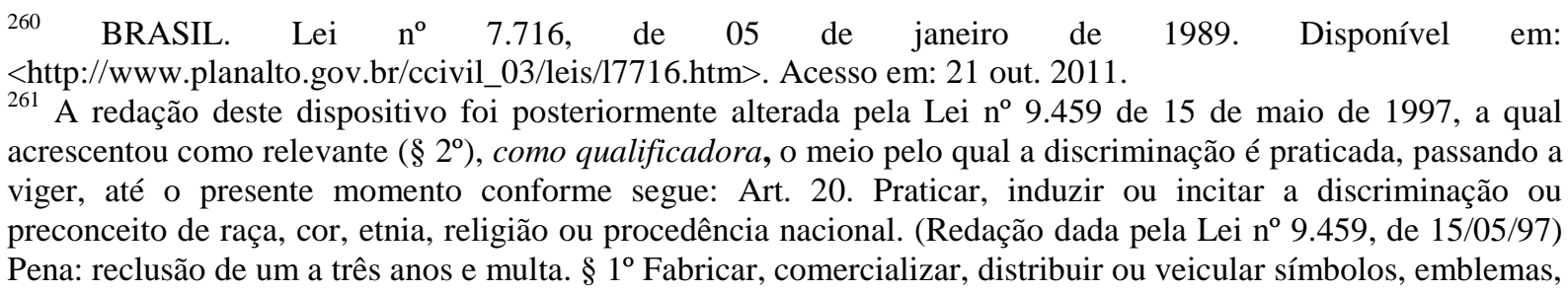


Segue-se daí o problema semântico se judeus constituem ou não raça ou, mais propriamente, se são ou não sujeitos passivos do crime de racismo. Ou seja, o cerne da questão semântica que permeia os votos de todos os Ministros do STF é se o termo racismo compreenderia ou não a discriminação contra judeus, o que é o primeiro ponto do debate ${ }^{262}$.

Daí porque, é feita consulta a Celso Lafer em que se questiona se o crime cometido por Siegfried Ellwanger é de prática de racismo, nos termos constitucionais e da legislação infraconstitucional. Lafer, na condição de amicus curiae, parte da premissa de que há interconexão entre o Direito interno e o Direito Internacional em matéria de Direitos Humanos e embasa-se no item 17 da Resolução 623 da Assembleia da Organização das Nações Unidas (ONU), que "insta todos os governos a cooperar com o relator especial da Comissão dos Direitos Humanos incumbido de examinar as formas contemporâneas de racismo, discriminação racial, xenofobia e outras formas correlatas de intolerância",263, inserindo-se nesse item como formas contemporâneas de racismo e discriminação racial, dentre outras, o antissemitismo.

A resposta de Lafer ${ }^{264}$ à consulta formulada, portanto, é de que o crime cometido por Siegfried Ellwanger é de prática de racismo e é, como tal, imprescritível, tendo por razões e fundamentos jurídicos de tal parecer oito conclusões: a primeira de que o art. $5^{\circ}$, XLII da CF, por estar inserido no rol de direitos e garantias fundamentais, tutelado por cláusula pétrea (Art. $60, \S 4^{\circ}$, inciso IV da CF), teria por vis directiva do constituinte a estabilidade e

ornamentos, distintivos ou propaganda que utilizem a cruz suástica ou gamada, para fins de divulgação do nazismo. (Redação dada pela Lei $n^{\circ} 9.459$, de 15/05/97) Pena: reclusão de dois a cinco anos e multa. $\S 2^{\circ}$ Se qualquer dos crimes previstos no caput é cometido por intermédio dos meios de comunicação social ou publicação de qualquer natureza: (Redação dada pela Lei no 9.459, de 15/05/97) Pena: reclusão de dois a cinco anos e multa. $\S 3^{\circ}$ No caso do parágrafo anterior, o juiz poderá determinar, ouvido o Ministério Público ou a pedido deste, ainda antes do inquérito policial, sob pena de desobediência: (Redação dada pela Lei $\mathrm{n}^{\circ}$ 9.459, de 15/05/97) I - o recolhimento imediato ou a busca e apreensão dos exemplares do material respectivo; II - a cessação das respectivas transmissões radiofônicas ou televisivas. III - a interdição das respectivas mensagens ou páginas de informação na rede mundial de computadores. (Incluído pela Lei $n^{\circ} 12.288$, de 2010 ) $\S 4^{\circ} \mathrm{Na}$ hipótese do $\S 2^{\circ}$, constitui efeito da condenação, após o trânsito em julgado da decisão, a destruição do material apreendido. (Parágrafo incluído pela Lei $\mathrm{n}^{\circ}$ 9.459, de 15/05/97).

262 "O crime de prática do racismo, como concluiu o acórdão do Superior Tribunal de Justiça, confirmando o entendimento do Tribunal de Justiça do Rio Grande do Sul, não se baseia no termo "raça", que tem conotação pseudocientífica - como adiante se verá com o devido rigor - mas sim nas teorias e concepções que atribuem ao termo raça o fundamento da discriminação, condenada pelo art. 5, LXII, da Constituição de 1988. É por esta razão que o impetrante comete uma falácia argumentativa ao afirmar que o crime de Siegfried Ellwanger não se subsume como prática de racismo nos termos do art. 20 da Lei 8.081/90, uma vez que os judeus não são uma raça e por isso mesmo o delito cometido pelo seu paciente é o do incitamento contra o judaísmo e não o da prática do racismo". [grifo nosso] LAFER, Celso. O caso Ellwanger: anti-semitismo como crime da prática do racismo. Revista de Informação Legislativa, Brasília, a. 41, n. 162, p. 53-89, abr./jun. 2004, p. 61.

${ }^{263}$ LAFER, Celso. O caso Ellwanger: anti-semitismo como crime da prática do racismo. Revista de Informação Legislativa, Brasília, a. 41, n. 162, p. 53-89, abr./jun. 2004, p. 58.

${ }^{264}$ LAFER, Celso. O caso Ellwanger: anti-semitismo como crime da prática do racismo. Revista de Informação Legislativa, Brasília, a. 41, n. 162, p. 53-89, abr./jun. 2004. 
permanência de um sistema integrado de valores da convivência coletiva, que tem como valor-fonte a dignidade da pessoa humana .

A segunda conclusão é a de que o art. $5^{\circ}$, XLII da CF exprime a etapa de especificação do processo histórico de positivação dos Direitos Humanos e de que, nesse processo, o constituinte atribuiu à prática do racismo uma excepcional gravidade, daí advindo o extraordinário rigor da tutela penal nele contemplada ao prever a imprescritibilidade.

A terceira conclusão é de que o critério da interpretação desse dispositivo constitucional deve favorecer de maneira ampla e não restritiva o conteúdo do Direito e em tal interpretação, o Direito Interno e o Direito Internacional interagem e não são estanques com vistas a reforçar a imperatividade do direito constitucionalmente garantido, voltado a impedir a prática do racismo.

Na quarta conclusão, entende-se que discutir o crime da prática do racismo a partir do termo raça, conforme argumentos apresentados no $\mathrm{HC} \mathrm{n}^{\circ}$ 82.424-2/RS em favor de Ellwanger, é uma maneira de reduzir e esvaziar completamente o conteúdo jurídico do preceito constitucional consagrado pelo art. $5^{\circ}$, XLII da CF, convertendo-o em crime impossível, uma vez que se racismo refere-se a raça e esta não tem base biológica, não haveria objeto e, por conseguinte, tampouco crime.

Assim, não obstante do ponto vista biológico não exista raça e este seja conceito pseudocientífico, isso não impediria a efetiva existência do crime de racismo, consubstanciado em práticas discriminatórias de cunho histórico-social.

$\mathrm{Na}$ quinta conclusão do parecer, Lafer baseia-se em dois casos decididos, respectivamente, pela Suprema Corte dos Estados Unidos e pela House of Lords da Inglaterra, em matéria de prática de racismo, nos quais se atribuiu ao termo raça uma acepção cultural e histórica permitindo-se a inserção de discriminação por religião ou etnia no crime de racismo, o que solaparia as alegações do $\mathrm{HC} \mathrm{n}^{\circ}$ 82.424-2/RS.

Esse raciocínio leva à sexta conclusão de que o conteúdo jurídico do crime da prática do racismo tem o seu núcleo nas teorias e ideologias, e na sua divulgação, que discriminam grupos e pessoas, a elas atribuindo as características de uma "raça inferior".

Na sétima conclusão, Lafer considera como uma das causas dos Direitos Humanos como tema da agenda internacional a própria desfaçatez do nazismo que, baseado na teoria de uma "raça superior", promoveu ódios públicos e perseguição de judeus como uma "raça inferior" a ser exterminada. Tendo a inclusão dos Direitos Humanos como um tema global levado a uma abrangente política culminando na positivação, generalização e especificação do Direito Internacional da Pessoa Humana. 
Finalmente, em sua oitava e última conclusão, Lafer sustenta que não é correta a alegação do impetrante de que o discurso racista, em nosso país, foi sempre dirigido contra o negro e de que o tema da discriminação racial se coloca exclusivamente em torno da cor da pele, uma vez que haveria registros de discurso racista e práticas racistas contra o negro, o mulato, o índio, o cigano e o judeu, considerados em muitos momentos da História pátria como "seres inferiores" e, por tal razão, a tipificação determinada pelo art. $5^{\circ}$, XLII da CF seria abrangente não apenas do preconceito por cor: "Subsume, assim, na sua tutela, o antisemitismo [sic] como prática de racismo e é, portanto, inteiramente aplicável à conduta criminosa de Siegfried Ellwanger" ${ }^{\text {265 }}$, consoante seu parecer.

\subsubsection{Síntese dos votos dos julgadores}

O STF decidiu o caso Ellwanger indeferindo a concessão do habeas corpus, mantendo-se a condenação do paciente, Siegfried Ellwanger, por oito votos a três. Foram votos vencedores o do Ministro Maurício Corrêa, relator do acórdão, e os dos Ministros Celso de Mello, Gilmar Mendes, Carlos Velloso, Nelson Jobim, Ellen Gracie, Cezar Peluso e Sepúlveda Pertence.

Foram vencidos os Ministros Moreira Alves, relator originário, e o Ministro Marco Aurélio Mello, ambos sob o fundamento de que o habeas corpus deveria ser concedido em razão de o crime cometido não se tratar de racismo, sendo, portanto, prescritível, e já prescrita a pretensão punitiva estatal; bem como o Ministro Carlos Ayres Britto, destoando de todos os demais Ministros, uma vez que decidiu pela concessão do habeas corpus ex officio, absolvendo Ellwanger por falta de tipicidade da conduta, por entender, a despeito do próprio reconhecimento do impetrante de que praticara crime - embora alegasse que não de racismo que sequer houvera crime, mas mero exercício da liberdade de expressão.

Conforme síntese de Celso Lafer ${ }^{266}$ :

Ao decidir o HC, o STF tratou de dois grandes temas. O primeiro foi o da abrangência do crime da prática do racismo para definir se o anti-semitismo [sic] é racismo. O segundo versou sobre o eventual conflito de princípios constitucionais, ponderando no caso concreto a existência ou não de uma

\footnotetext{
${ }^{265}$ LAFER, Celso. O caso Ellwanger: anti-semitismo como crime da prática do racismo. Revista de Informação Legislativa, Brasília, a. 41, n. 162, p. 53-89, abr./jun. 2004, p. 84.

${ }^{266}$ LAFER, Celso. A internacionalização dos Direitos Humanos. Constituição, Racismo e Relações Internacionais. Barueri, SP: Manole, 2005, p. 99.
} 
antinomia entre a liberdade de manifestação do pensamento e a condenação de Ellwanger pelo crime da prática de racismo.

Os votos, contudo, apresentam certas peculiaridades. Não foram todos os Ministros que apreciaram ambas as questões: todos apreciaram o problema semântico, alguns se ativeram a ele, e poucos, com limitações, enfrentaram o conflito de princípios. Vale, portanto, avaliar em síntese o posicionamento de cada julgador.

\subsection{Voto do Ministro Moreira Alves}

O Relator originário do caso é o Ministro Moreira Alves, o qual se cingiu ao aspecto semântico acima aludido de se saber se a discriminação praticada por Ellwanger contra judeus tratava-se ou não de racismo, não tendo nem analisado e tampouco citado o conflito de princípios subjacente.

Para Moreira Alves, a questão do habeas corpus seria apenas a determinação do sentido e alcance da expressão 'racismo', cuja definição fora transferida pelo constituinte à lei ordinária, vindo a Lei $\mathrm{n}^{\mathrm{o}} 7.716 / 89$ a definir como prática de racismo condutas de discriminação pertinentes à raça e à cor e, posteriormente, ampliando-se, com o advento da Lei $\mathrm{n}^{\mathrm{o}}$ 8.081/90, a abrangência da lei anterior abarcando também como racismo a discriminação à religião, etnia ou procedência nacional.

No entanto, o Ministro Relator Moreira Alves entendeu que o Art. 5 , XLII da CF não abrangia qualquer forma de discriminação, mas apenas a discriminação contra o negro, uma vez que no cenário brasileiro o elemento histórico daria ao racismo o significado de preconceito ou discriminação racial mais especificamente contra a raça negra ${ }^{267}$.

Tanto assim, que o Ministro recorreu à mens legislatoris, invocando como justificativa para sua interpretação restritiva de racismo a motivação do constituinte originário e, em especial, do Constituinte Carlos Alberto Caó que, ao elaborar a Emenda Aditiva 2P00654-0, apresentada em 12.01.1988, originando o Art. $5^{\circ}$, XLII da CF, teria por justificação o fato de que a discriminação contra negros no Brasil não cessara com a abolição da escravatura, urgindo medidas para essa tutela específica do negro.

Destarte, o Relator originário considerou que os judeus não são raça - até pelas divergências que cita se seriam membros de religião ou povo, apesar, neste caso, da dispersão

\footnotetext{
${ }^{267} \mathrm{O}$ ministro parte da divisão tradicional antropológica de raças entre negra, amarela e branca, calcando-se em parâmetro eminentemente biológico na caracterização de raça.
} 
territorial - e deferiu o habeas corpus, uma vez que considerou que Ellwanger não praticou o crime de racismo e, por conseguinte, estaria prescrita a pretensão punitiva contra ele.

Após o voto-vista do Ministro Maurício Corrêa e a análise do parecer de Celso Lafer, Moreira Alves reiterou seu voto, desconsiderando que os judeus tenham efetivamente sofrido preconceito racial na história do Brasil e ratificando não se tratar de crime de racismo ao qual se atribuiu imprescritibilidade.

O Ministro Moreira Alves apresentou duas razões para a interpretação restritiva: que a imprescritibilidade é considerada como aberração, de modo que, embora o significado de racismo seja plural, a excepcionalidade da medida - imprescritibilidade - exigiria interpretação restritiva, até mesmo pela vontade do constituinte originário, como acima referido; e que as convenções internacionais invocadas pelo parecer de Celso Lafer, embora considerassem o antissemitismo como racismo, não impunham imprescritibilidade ao racismo, o que também justificaria a interpretação restritiva do art. $5^{\circ}$, XLII da CF, além do fato de ressalvar que as peculiaridades nacionais impõem reservas à interpretação do Direito nacional com base no Direito estrangeiro ou internacional.

\subsection{Voto do Ministro Maurício Corrêa}

No extenso voto do Ministro Maurício Corrêa, eminentemente lastreado no parecer de Celso Lafer, é dada ênfase ao aspecto semântico, relativo à acepção de raça e ao enquadramento de discriminação de judeus como prática do crime de racismo, sendo apenas citado o conflito de normas fundamentais - entre liberdade de expressão e honra, para ele -, postulando-se sua harmonização, tendo-se em vista os tratados internacionais ratificados pelo Brasil com ampla defesa dos direitos humanos e da dignidade humana.

Em seu voto, Maurício Corrêa afirma que a questão gira em torno da exegese do termo racismo. Divergindo do Ministro Moreira Alves, Maurício Corrêa começa por refutar a consideração de raça como expressão simplesmente biológica, uma vez que seu sentido resultaria também de valoração antropológica e aspectos sociológicos. Até mesmo por considerar a definição antropológica clássica - de classificação de raças em brancos, negros e amarelos - ultrapassada, o que fora ratificado pelas descobertas do Projeto Genoma Humano que demonstraram ser o conceito biológico de raça pseudocientífico, como registrou o Ministro. 
Assim, Corrêa considerou que a distinção de raças decorre de um processo políticosocial originado da intolerância dos homens, uma vez que haveria uma única raça ou espécie humana. No entanto, como enfatiza o Ministro, embora não se reconheça mais, sob o prisma científico, subdivisão da raça humana, o racismo persiste enquanto fenômeno social, afastando assim, a alegação considerada falaciosa de que inexistindo a distinção de raças, não haveria o crime de racismo.

Daí porque Corrêa desvencilha o crime de racismo da acepção de raça enquanto conceito biológico, colocando-o como fenômeno estrita e eminentemente social. Acrescenta ainda que raça distingue-se de cor (conforme se depreende do Art. $3^{\circ}$, IV da CF), por ter aquele termo conteúdo mais amplo que este, sendo que seriam as próprias normas de Direito Internacional voltadas à tutela dos direitos e da dignidade humana - em que o antissemitismo fora taxativamente considerado como forma de racismo - ratificadas pelo Brasil ${ }^{268}$, a inspiração tanto do legislador constituinte de 1988, quanto do legislador infraconstitucional ao disciplinar o crime de racismo no ordenamento pátrio.

No mesmo sentido, reforçou a importância do Direito Internacional para colmatar o sentido das normas do Direito pátrio ao citar o $\mathrm{HC} \mathrm{n}^{\circ} 70.389^{269}$, relatado pelo Ministro Celso de Mello, julgado em 10.08.2001, o qual se assentou em atos normativos internacionais considerados como "subsídios relevantes para a adequada compreensão da noção típica do crime de tortura...", o que também poderia ser feito com a correta exegese a ser dada ao crime de racismo que, tal como o de tortura, violaria os postulados gerais dos direitos humanos, justificando o recurso ao Direito Internacional.

\footnotetext{
${ }^{268}$ Entre as normas de direito internacional, Corrêa cita o Art. $1^{\circ}$ Declaração sobre Raça e Preconceito Racial, da $20^{\mathrm{a}}$ sessão da conferência geral Unesco em 27 de novembro de 1978. A Declaração Universal dos Direitos Humanos de 1948, Art. $1^{\circ}$ que assegura liberdade e igualdade entre os homens e a repulsão a qualquer forma de discriminação. O pronunciamento do Brasil perante a Assembleia Geral da ONU em 1960 repudiando a perseguição racial e políticas de segregação com base em distinção de raça, cor ou religião, ocasião em que se consignou a adesão do Brasil à Convenção Internacional contra o Genocídio. A Convenção Internacional sobre a Eliminação de todas as formas de Discriminação Racial de 1965, assinada pelo Brasil e ratificada sem reservas mediante o Decreto ${ }^{\circ}$ 65810/69. O Pacto Internacional sobre Direitos Civis e Políticos de 1966, que previa a proibição da "apologia do ódio nacional, racial ou religioso que constitua incitamento à discriminação, à hostilidade ou à violência", reiterado para as Américas no artigo 13-5 do Pacto de São José da Costa Rica e incorporado ao direito brasileiro (Decreto legislativo 89/98, Decreto 678/92, e Decreto 4463/02). Cita ainda a ratificação da matéria na Conferencia Mundial sobre Direitos Humanos em Viena, em 14.06.1993 e a Resolução 623 da Assembleia Geral da ONU de dezembro de 1998 que insta países a cooperar com a Comissão de Direitos Humanos no exame de todas as formas contemporâneas de racismo, como xenofobia, negrofobia, anti-semitismo e outras formas correlatas de intolerância racial (item 17 da resolução). BRASIL. Supremo Tribunal Federal. Habeas Corpus $\mathrm{n}^{\circ}$ 82.424-2/RS. Ministro Relator Moreira Alves. Ministro Relator para o Acórdão Maurício Corrêa. Julgado em 17.09.2003. D.J. $\quad$ 19.03.2004. Disponível em: <http://redir.stf.jus.br/paginadorpub/paginador.jsp?docTP=AC\&docID=79052>. Acesso em: 21 out. 2011.

269 BRASIL. Supremo Tribunal Federal. Habeas Corpus no 70.389/SP. Ministro Relator Sydnei Sanches. Ministro Relator para o Acórdão Celso de Mello. Julgado em 23.06.1994, D.J. 10.08.2001. Disponível em: <http://redir.stf.jus.br/paginadorpub/paginador.jsp?docTP=AC\&docID=72400>. Acesso em 21 out. 2011.
} 
Corrêa citou igualmente o Direito comparado e a jurisprudência norte-americana e inglesa para ratificar a posição de que a discriminação contra judeus se trata de prática crime de racismo ao qual o constituinte previra imprescritibilidade no Art. 5 , XLII da CF, até mesmo porque, historicamente, no período do Brasil colônia, os judeus e, até mesmo os chamados 'cristãos-novos', eram considerados, nos termos do Ministro, 'raça infecta'.

Por essa razão, entendeu Corrêa que na Lei n $n^{\circ} 7.716 / 89$, alterada pela Lei ${ }^{\circ} 8.081 / 90$, o legislador teria estabelecido o alcance de raça não limitada à cor da pele e que a referência a negros nos debates da Assembleia Constituinte sobre o tema seria decorrência da dívida da sociedade nacional para com a comunidade negra, não implicando restrição da aplicação da norma constitucional apenas a casos de discriminação contra negros.

A partir disso, o Ministro concluiu que a discriminação contra judeus é crime de racismo, tendo-se em vista uma interpretação teleológica e harmônica da Constituição Federal, das normas internacionais e das leis ordinárias, e que as publicações levadas a efeito por Ellwanger, sob o pretexto de serem mero 'revisionismo histórico', procurariam em verdade negar fatos históricos relacionados às perseguições contra judeus, em especial o holocausto, incentivando a discriminação racial contra judeus.

No concernente ao segundo problema, de conflito de princípios constitucionais - a liberdade de expressão de Ellwanger e a dignidade de judeus - o Ministro Corrêa entendeu não haver violação ao princípio constitucional da liberdade de expressão $\left(\mathrm{CF}, \operatorname{Art}\right.$. $5^{\circ}$, IV e IX; e Art. 220), uma vez que a própria Constituição Federal estabelecera os limites para seu exercício (Art. $5^{\circ}, \S 2^{\circ}$, primeira parte).

Assim, postulou que a previsão de liberdade de expressão não assegura o direito à incitação ao racismo, pois um direito individual não pode servir de salvaguarda a práticas ilícitas, tal como ocorreu em relação aos delitos contra a honra - calúnia, injúria e difamação - no Código Penal, como adequados limitativos dessa liberdade.

Não obstante tenha-se referido a, mas não reconhecido o conflito de princípios, o Ministro Maurício Corrêa defendeu a necessidade de temperamentos ante conflito de normas fundamentais ( $\mathrm{CF}$, Art. 220, caput, in fine), cabendo ao intérprete a harmonização de bens jurídicos em oposição, citando como problema de conflito de princípio semelhante ao caso Ellwanger, a ponderação levada a cabo na Reclamação $n^{\circ} 2040^{270}$, relatada pelo Ministro Néri

\footnotetext{
${ }^{270}$ Dentre outros, no caso, discutia-se a contraposição entre, por um lado, o direito à honra de policiais acusados de estupro e à imagem da própria Polícia Federal, e de outro, o direito à intimidade de Gloria Trevi, isso tendo em vista o pedido de realização de exame de DNA para se saber se seu filho fora fruto de abuso sexual dentro da prisão; tendo prevalecido os primeiros princípios, autorizando-se a realização do referido exame. BRASIL. Supremo Tribunal Federal. Questão de Ordem em Reclamação no 2040/DF. Ministro Relator Néri da Silveira.
} 
da Silveira e julgada em 21.02.2002, conhecida como Caso Glória Trevi, em que ante o conflito de princípios, a decisão baseou-se no entendimento da prevalência de um direito fundamental sobre o outro.

O que denota a dificuldade em se extrair da decisão de Corrêa o efetivo reconhecimento ou não do conflito de princípios, pois embora não entenda haver conflito entre a liberdade de expressão e a dignidade - por entender que a liberdade de expressão não está tutelada no caso - acaba citando um caso de conflito de princípios julgado pelo STF como semelhante ao Caso Ellwanger, supostamente também com tal conflito.

No entanto, se o Ministro reconhecera o conflito, não o enfrentou e baseou sua decisão na solução do problema semântico, indeferindo a ordem de habeas corpus sob o argumento de que a edição e venda de livros ${ }^{271}$ fazendo apologia a ideias preconceituosas e discriminatórias (Art. 20 da Lei $n^{\circ} 7.716 / 89$, com redação da Lei $n^{\circ}$ 8.081/90), como em seu entendimento fez Ellwanger, é crime imprescritível de racismo (Art. 5º, XLII da CF).

\subsection{Voto do Ministro Celso de Mello}

Em seu voto, embora o Ministro Celso de Mello cite a possibilidade concreta de haver conflito de princípios, apontando o método da ponderação como racional e adequado para resolver esse tipo de conflito, desconhece, contudo, que no caso Ellwanger ele exista e entende que a controvérsia do caso restringe-se ao problema semântico de se saber se a prática do antissemitismo subsume-se ou não à noção mesma de racismo, especialmente, para efeito da incidência da cláusula da imprescritibilidade do Art. 5º XLII da CF.

Na linha de Maurício Corrêa, Celso de Mello entende que, do ponto de vista semântico, a noção de racismo não se resume a um conceito estritamente antropológico ou biológico, projetando-se em uma dimensão cultural e sociológica, até mesmo como instrumento de controle ideológico, dominação política e subjugação social.

Para a solução da questão semântica, o Ministro ainda enfatiza a necessidade de a interpretação jurídica considerar tanto o Direito interno quanto o Direito Internacional, uma vez que a questão envolve matéria relativa a direitos humanos. E, como demais Ministros,

\footnotetext{
Julgada em 21.02.2002. D.J. 27.06.2003. Disponível el <http://redir.stf.jus.br/paginadorpub/paginador.jsp?docTP=AC\&docID=87540>. Acesso em: 20 out. 2011.

${ }^{271}$ Os livros de Ellwanger aludidos por Maurício Corrêa são: de publicação do paciente "O Judeu Internacional" de Henry Ford; "A história Secreta do Brasil" e "Brasil Colônia de Barqueiros", ambos de Gustavo Barroso; "Os Protocolos dos Sábios de Sião", "Hitler - culpado ou inocente?", de Sérgio Oliveira; "Os Conquistadores do Mundo - os verdadeiros criminosos de guerra", de Louis Marschalko; e de sua autoria, "Holocausto Judeu ou Alemão? Nos bastidores da mentira do século".
} 
Celso de Mello também remete à Resolução 623 da Assembleia Geral da Organização das Nações Unidas, de 09.12.1998, que proclama o antissemitismo e todos os atos de intolerância a ele relacionados como manifestações de formas contemporâneas de racismo ${ }^{272}$.

Assim, o Ministro postula que o legislador pátrio tem como desafio extrair das declarações internacionais e das proclamações constitucionais de direitos a máxima eficácia, discordando do Ministro Relator originário, Moreira Alves, quanto à opção deste de uma interpretação restritiva, uma vez que Celso de Mello entende que não é cabível um processo hermenêutico que, conforme suas palavras, frustre a força normativa da Constituição em razão do uso de critérios exegéticos que subtraiam aos postulados da dignidade humana e da igualdade jurídica a sua máxima eficácia, de forma despojada da abrangência que lhe quis emprestar o próprio legislador constituinte.

No que tange ao problema do conflito de princípios, o Ministro manifesta-se sobre a liberdade de expressão enfatizando que não há direitos absolutos e, por conseguinte, são admissíveis, ainda que excepcionalmente, medidas restritivas das prerrogativas individuais ou coletivas - não se admitindo, porém, censura prévia -, desde que respeitados os termos da própria Constituição Federal, com vistas a assegurar a coexistência harmoniosa das liberdades.

Dessa maneira, postula que o direito à livre expressão do pensamento sofre limitações de natureza ética e de caráter jurídico, e eventuais abusos legitimam a reação estatal $a$ posteriori, mediante sanções jurídicas. Reconhecendo, pois, que há casos em que o exercício concreto da liberdade de expressão pode gerar tensão dialética entre valores essenciais, igualmente protegidos pelo ordenamento constitucional, o que implica um estado de colisão de direitos ou confronto de liberdades de mesma estatura jurídica, sendo a melhor forma de solucioná-los o método da ponderação, desde que não importe esvaziamento do conteúdo essencial dos direitos fundamentais.

No entanto, o Ministro entende que esta não é a situação do Caso Ellwanger, pois neste não haveria conflito entre direitos básicos titularizados por sujeitos diversos, uma vez que manifestações discriminatórias não estão compreendidas na liberdade de expressão, então

\footnotetext{
${ }^{272}$ Cita além das convenções internacionais já referidas por Maurício Corrêa a Declaração de Durban e Plano de Ação, resultante da III Conferência Mundial de Combate ao Racismo, à Discriminação Racial, à xenofobia e à intolerância correlata (África do Sul/2001) e a Conferência Mundial sobre Direitos Humanos, de Viena em 1993, como passo decisivo no processo de reconhecimento, consolidação e contínua expansão dos direitos básicos da pessoa humana. BRASIL. Supremo Tribunal Federal. Habeas Corpus $\mathrm{n}^{\circ}$ 82.424-2/RS. Ministro Relator Moreira Alves. Ministro Relator para o Acórdão Maurício Corrêa. Julgado em 17.09.2003. D.J. 19.03.2004. Disponível em: <http://redir.stf.jus.br/paginadorpub/paginador.jsp?docTP=AC\&docID=79052>. Acesso em: 21 out. 2011.
} 
este não seria um princípio efetivamente em jogo e tampouco em conflito com a dignidade da humana.

Partindo dessa perspectiva e considerando que o termo racismo abarca em seu âmbito de significação a prática de antissemitismo, o Ministro concluiu que publicações como a de Ellwanger extravasavam os limites da indagação científica e da pesquisa histórica, não se inserindo na proteção constitucional que assegura a liberdade de expressão do pensamento, a qual não compreenderia em seu âmbito de tutela manifestações revestidas de ilicitude penal.

Daí porque seu voto baseou-se na solução da questão semântica, mediante a compreensão do antissemitismo na abrangência do termo racismo, com a consequente manutenção dos efeitos da condenação pelo indeferimento do habeas corpus.

\subsection{Voto de Gilmar Mendes}

Em seu voto, o Ministro Gilmar Mendes transcende a questão semântica e não apenas reconhece o conflito de princípios constitucionais, como busca solucioná-lo mediante aplicação no caso concreto, embora com limitações, do método da ponderação propugnado por Robert Alexy.

No que diz respeito à significação de racismo, Mendes entendeu a concepção sobre existência de raças como pseudocientífica, sem que isso viesse a impedir o estabelecimento do racismo com base em outros critérios. Embasado em Norberto Bobbio, o Ministro referiuse a três condições ou postulados do racismo: primeiro, que raças são tomadas como grupos humanos com caracteres que se transferem por hereditariedade; segundo, que não apenas há raças diversas, mas distinguíveis em superiores e inferiores; terceiro, que as raças que são superiores, porque são superiores, têm o direito de dominar as inferiores, extraindo disso todas as vantagens possíveis.

Assim, do ponto de vista estritamente histórico, seria inegável o caráter racista do antissemitismo, até mesmo pela busca da 'pureza racial' caracterizadora do nacionalsocialismo. Dessa maneira, o conceito jurídico de racismo não se afastaria do conceito histórico, sociológico e cultural com base em referências supostamente raciais - não estritamente, a partir do conceito pseudocientífico de raça -, incluído o antissemitismo.

Quanto ao conflito de princípios, Mendes explicita que a liberdade de expressão é uma pedra angular do próprio sistema democrático e que em sociedades democráticas há preocupação com o exercício de liberdade de expressão que leve à incitação à discriminação 
racial, uma vez que essa compromete a ideia de igualdade, também um dos pilares do sistema democrático.

Daí porque reitera que a liberdade de expressão não tem primazia absoluta e deve se compatibilizar com o direito à imagem, à honra e à vida privada $\left(\mathrm{CF}, \mathrm{Art} .5^{\circ}, \mathrm{X}\right)$, legitimandose a intervenção legislativa para harmonizar valores constitucionais eventualmente em conflito, como a própria igualdade e a dignidade humana, justificando-se, pois, as normas do Art. $5^{\circ}$, incisos XLI e XLII da CF.

No caso Ellwanger, o Ministro reconheceu o conflito entre a liberdade de expressão de Ellwanger e a dignidade de judeus, postulando a aplicação do método da ponderação como expressão do princípio da proporcionalidade, que permitiria estabelecer um "limite do limite" ou "proibição do excesso" na restrição de direitos.

O Ministro passou à avaliação do caso concreto partindo do questionamento se a decisão condenatória prolatada pelo Tribunal de Justiça do Rio Grande do Sul, em sede de apelação à decisão absolutória de primeiro grau, atendia às três máximas parciais da proporcionalidade (adequação, necessidade e proporcionalidade em sentido estrito).

Quanto ao questionamento da adequação da condenação para alcançar o fim almejado de salvaguarda de uma sociedade pluralista, onde reinasse tolerância e houvesse defesa da dignidade da pessoa humana (art. $1^{\circ}$, III da CF) e pluralismo político (Art. $1^{\circ}, \mathrm{V}$ da CF), o Ministro entendeu ser evidente a adequação da medida, embora não tenha demonstrado cabalmente que a imprescritibilidade prevista no Art. $5^{\circ}$, XLII da CF implica tal desiderato.

Quanto à necessidade da condenação, entendeu indubitavelmente necessária pela inexistência de outro meio menos gravoso e igualmente eficaz, uma vez que, em seu argumento, o próprio constituinte determinara a criminalização e a imprescritibilidade da prática do racismo, não havendo exorbitância no acórdão, pois o caso não se tratava de obras revisionistas da história, mas de ideias atentatórias à dignidade dos judeus e de textos que estimulavam ódio e violência contra os judeus, e o Tribunal de Justiça teria agido com cautela na dosagem da pena, atendendo ao princípio da proibição do excesso.

Também estaria atendido o requisito da proporcionalidade em sentido estrito, por haver proporção entre o objetivo perseguido de preservar valores inerentes a uma sociedade pluralista, da dignidade humana e o ônus imposto à liberdade de expressão de Ellwanger, até mesmo porque o Ministro considerou inegável que a liberdade de expressão não alcança a intolerância racial e o estímulo à violência, tal como fora afirmado no acórdão condenatório.

Desse modo, não obstante não tenha aplicado a fórmula de peso e nem demonstrado ou tampouco justificado quais os pesos atribuídos aos princípios em colisão, a aplicação do 
método da ponderação é invocada pelo Ministro Gilmar Mendes como justificativa para o entendimento de que a decisão recursal fora proporcional, razão para seu indeferimento do habeas corpus.

\subsection{Voto do Ministro Carlos Velloso}

O Ministro Carlos Velloso tratou tanto do problema semântico e, pois, da questão da subsunção, como do problema do conflito de princípios - dignidade humana e liberdade de expressão. No entanto, entendendo a dignidade humana como dotada de especial relevo na Constituição, entendeu-a como limitativa da própria liberdade de expressão, o que implicaria uma solução constitucional prévia impeditiva do conflito efetivo neste caso concreto ${ }^{273}$.

Inicialmente, o voto do Ministro partiu da questão semântica de se saber se a prática de antissemitismo seria considerada racismo, tomando-se como base o Art. 20 da Lei 7.716/89 com redação da Lei no 8.081/90.

Tal como demais Ministros, Velloso entendeu que, especialmente com o sequenciamento do genoma humano, fora demonstrada a impossibilidade de se falar em raças em termos biológicos ou antropológicos, o que não impedira tratamento discriminatório e preconceituoso caracterizador de racismo, justificando-se a tutela constitucional do Art. $5^{\circ}$, XLII da CF.

Em seu entendimento, os livros editados ou o escrito por Ellwanger não veiculavam simplesmente teses ideológicas, mas pregavam preconceito e estimulavam ódio contra judeus, o que implicaria prática de racismo ao qual a Constituição atribuiu imprescritibilidade.

Quanto ao conflito de princípios, Velloso apontou que, muito embora a liberdade de expressão fosse constitucionalmente assegurada (CF, Art. 5\%, IV e IX e Art. 220), a incitação ao ódio público contra o povo judeu não estaria protegida por esta cláusula constitucional. Assim, não havendo direitos absolutos, a liberdade de expressão não poderia acobertar manifestações preconceituosas e racistas, atentatórias à dignidade humana e a direitos fundamentais consagrados na Constituição Federal (Art. 4 , VIII, Art. 5º, XLII), de modo que a liberdade de expressão não poderia sobrepor-se à dignidade da pessoa humana.

\footnotetext{
${ }^{273}$ Diferentemente de Gilmar Mendes, que identifica o conflito de princípios concretamente, buscando resolvê-lo pela aplicação do método da ponderação, Carlos Velloso não chega a reconhecer o conflito concreto, porque entende que o legislador já havia realizado a ponderação, tendo estabelecido que a liberdade de expressão não pode ser usada para atingir a dignidade e, pois, estaria legislativamente predeterminada a prevalência desta, não gerando conflito concreto.
} 
Por tal razão, o racismo como conduta criminosa (art. 5 $5^{\circ}$ XLII da CF) e condutas típicas não poderiam ser consideradas sob o princípio da liberdade de expressão, por serem atentatórias ao princípio maior da dignidade humana, consagrada na Constituição Federal como fundamento da República (art. $1^{\circ}$, III da CF).

No caso Ellwanger, o Ministro entendeu que o conflito de princípios não era, pois, efetivo, pois ao praticar antissemitismo Ellwanger teria praticado racismo, o qual não está salvaguardado pela liberdade de expressão, que já tem em seu bojo como premissa e limite a dignidade humana.

Com isso, ao resolver a questão semântica entendendo subsumir-se o fato à norma, pelo reconhecimento da prática de antissemitismo como forma de racismo, e afastando de antemão o conflito concreto de princípios constitucionais como já abstratamente resolvido pelo constituinte, o Ministro indeferiu a ordem de habeas corpus.

\subsection{Voto do Ministro Nelson Jobim}

Para o Ministro Nelson Jobim, o cerne da controvérsia no caso Ellwanger estaria em se reconhecer ou não a condição de imprescritibilidade para o delito de discriminação contra judeus. Assim, o Ministro não ingressa no conflito de princípios, mantendo-se na discussão da questão semântica do termo racismo.

Jobim adota uma conceituação de racismo à qual considera pragmática, por atentar às práticas discriminatórias concretas, independentemente das considerações teóricas de que judeus são povo e não raça, e que, por isso, não estariam amparados pela Constituição, quanto à imprescritibilidade do delito; o que significaria, para ele, até mesmo, inaceitável esvaziamento do dispositivo constitucional correlato (Art. 5 , XLII da CF).

À interpelação do Ministro Sepúlveda Pertence sobre a adequação de se definir como crime de incitamento ao racismo a reedição de livros há bastante tempo conhecidos, Jobim destaca que a questão não é o problema específico da edição do livro, mas a forma e a motivação para que a edição tenha sido utilizada.

Reconhece o Ministro Jobim a edição do livro de Ellwanger como instrumento para a prática do racismo, já que pela análise do caso concreto restaria claro que as edições dos livros não foram por motivos históricos ou revisionais, mas para fins de se produzir o antissemitismo, sendo caso típico de racismo previsto tanto pelo Art. $5^{\circ}$ XLII da CF, como pela Lei infraconstitucional $n^{\circ} 7.716 / 89$, modificada pela Lei $n^{\circ} 8.081 / 90$. 
A liberdade de expressão é referida por Jobim como pressuposto e instrumento para a produção do debate democrático e, por outro lado, o ódio racial é considerado como causa de lesão à democracia.

Assim, sem entrar no conflito de princípios, o Ministro Nelson Jobim concluiu que os livros publicados por Ellwanger foram instrumento de ativismo racista, sendo que a Assembleia Constituinte não teria restringido a aplicação da imprescritibilidade de racismo ao preconceito contra negro, mas deixara em aberto a inserção de virtuais racismos, não conhecidos em 1988 - embora o antissemitismo já o fosse então -, de modo a se inserir o antissemitismo na abrangência semântica de racismo, denegando a ordem de habeas corpus.

\subsubsection{Voto da Ministra Ellen Gracie}

Em sucinto voto, a Ministra Ellen Gracie buscou afastar a argumentação de Ellwanger de que, não sendo judeu raça, não haveria crime de racismo no caso. Assim, todo o problema tratado fora o semântico e, pois, da subsunção, sequer vislumbrando conflito de princípios.

A Ministra afastou o argumento de que, sob o amparo na premissa de que há apenas uma única raça humana, o comportamento de Ellwanger não se poderia subsumir nos preceitos constitucionais que repudiam o preconceito racial, tornando imprescritíveis as ofensas cujo móvel fosse a discriminação.

Embora tenha reconhecido que, tomada isoladamente essa premissa, o comportamento de Ellwanger não se subsumiria aos preceitos constitucionais, aduziu que ao se falar em preconceito de raça e nas referências constitucionais a respeito, não se deveria pensar em critérios científicos, mas na percepção do outro como inferior, no menosprezo e no desrespeito a seu direito fundamental à igualdade, o que se constaria como sendo a conduta de Ellwanger, tomada pela Ministra como prática de racismo, justificativa para sua denegação do habeas corpus.

\subsection{Voto do Ministro Cezar Peluso}

Tal como a Ministra Ellen Gracie, o Ministro Cezar Peluso é sintético e restringe-se à questão semântica. Embora se refira ao conflito de princípios, já que trata de dignidade e de liberdade de expressão, não os contrapõe diretamente e tampouco os considera como mérito do Caso Ellwanger. 
O Ministro entende que, ao dispor sobre racismo no Art. 5ª XLII, a Constituição Federal não adotou nenhum rigoroso e puro conceito extrajurídico, mas um conceito próprio, logo, normativo, sendo necessária a interpretação teleológica, para se retirar da Constituição o conteúdo nuclear do conceito jurídico-penal de racismo, já que o objetivo desta tipificação seria preservar os fundamentos da República (Art. $1^{\text {o }}$, II e III da CF).

Dessa maneira, diferentemente do Ministro relator originário, Moreira Alves, o Ministro Peluso entendeu não ser lícito dar sentido restrito ao termo racismo, pois se limitaria a proteger conjuntos muito reduzidos de pessoas. Daí porque concluiu que Ellwanger, por ter publicado livros com o propósito de promover e difundir o antissemitismo, como particular manifestação da ideologia racista, instigando e reforçando preconceitos e ódios históricos, teria praticado racismo, justificando-se a incidência da imprescritibilidade, uma vez que sua conduta teria transposto os limites da liberdade de expressão.

Portanto, considerando a prática de Ellwanger como racismo, sem tratar do conflito de princípios, o Ministro Cezar Peluso denegou o habeas corpus.

\subsection{Voto do Ministro Carlos Ayres Britto}

A decisão do Ministro Carlos Ayres Britto é bastante inusitada em relação à de seus companheiros de Corte e ao próprio habeas corpus, já que a despeito da própria arguição da defesa que reconhecia o crime praticado por Ellwanger, embora buscasse descaracterizá-lo como de racismo, o Ministro votou no sentido da inexistência de crime, por atipicidade de conduta, como resultado, para além da questão semântica, de sua apreciação quanto ao conflito de princípios.

O Ministro principiou seu voto pelo levantamento de uma questão de ordem: a atipicidade da conduta de Ellwanger. Segundo Ayres Britto, em primeira instância, nem o Ministério Público e tampouco os assistentes da acusação fizeram prova de que o delito praticado por Ellwanger se materializara na vigência do dispositivo legal invocado na denúncia, ou seja, o Art. 20, caput da Lei no 7.716/89, com redação da Lei $n^{\circ}$ 8.081/90, tomada como fundamento único pela Câmara Criminal do Tribunal de Justiça do Rio Grande do Sul para reformar a sentença absolutória de primeira instância e condenar Ellwanger.

Destarte, para o Ministro, quando da conduta de Ellwanger, não havia tipificação legal e, por conseguinte, tampouco crime, por serem os fatos anteriores à tipificação, em detrimento da defesa do Ministro Nelson Jobim de que mesmo publicada a primeira edição em 1989, 
anteriormente à tipificação legal, o problema não seria da edição, mas da divulgação e campanha antissemita, depois de 1990.

Daí porque o Ministro Ayres Britto resolveu o problema do caso mediante a solução da questão de ordem, entendendo que à época dos fatos, não havia previsão legal, nem, pois, materialização do crime e tampouco pena, o que implicaria carência de justa causa para a postulação da ação penal pública. Justificativa esta para sua decisão no sentido de conceder de ofício, pela inovação da causa de decidir, o habeas corpus.

Não obstante, o Ministro prosseguiu no voto adentrando às demais questões. No que atine ao significado do termo racismo, o Ministro notou que o legislador constituinte estabeleceu clara diferença entre raça e cor ao citar no Art. $3^{\circ}$, IV da CF ambos os termos, impelindo o exegeta a deduzir que preconceito de raça e preconceito de cor são figuras jurídicas distintas.

No entanto, o Ministro apontou que tal interpretação semanticamente restritiva seria negativa da discriminação racial ao negro com amplos registros históricos no cenário nacional, bem como das próprias particularidades do processo constituinte, sob inspiração do Movimento Negro, com a específica proposta de Carlos Alberto Caó e Benedita da Silva quanto à emenda aditiva de inserção do Art. $5^{\circ}$, XLII da CF tendo em vista particularmente a realidade discriminatória contra o negro.

Assim, a solução para essa incompatibilidade entre a restrição semântica e a amplitude prática do termo 'racismo' no Brasil, associada, segundo o Ministro, a preconceito de cor, em especial contra o negro, exigiria interpretação histórico-cultural que atentasse à realidade pátria, que incluiria em sua tradição falar de raça para além da referência aos negros, abrangendo demais grupos com características histórico-culturais próprias, como nativos (índios), apátridas (ciganos) ou pessoas de outro Estado-nação.

Seguindo nessa linha argumentativa, o Ministro Ayres Britto salientou que se a Constituição falou de racismo e não de raça (Arts. $4^{\circ}$, VIII e $5^{\circ}$, XLII), a despeito da distinção do Art. $3^{\circ}$, IV da CF, fizera-o na pretensão de unificar essas modalidades de preconceito, com potencial de lesar a múltiplos princípios constitucionais, entre os quais a igualdade material (Arts. $6^{\circ}$ e $7^{\circ}$ da CF), a igualdade civil (Art. $5^{\circ}$ da CF) e o pluralismo.

Muito embora tenha reconhecido que judeus possam ser sujeitos passivos do crime de racismo, Ayres Britto entendeu que este não seria o caso, ao acatar o argumento da defesa de Ellwanger de que o livro deste seria pesquisa histórica em perspectiva revisionista, com finalidade de reabilitar a imagem do povo alemão e mostrar que a História fora contada pelos vencedores, o que seria, portanto, mera convicção político-ideológica, com respaldo 
constitucional em razão do pluralismo político como um dos fundamentos do Brasil (Art. $1^{\circ}$, $\mathrm{V}$ da $\mathrm{CF})$.

Dessa maneira, o embasamento da decisão de Ayres Britto assenta-se na solução do conflito de princípios por ele apreciado como premissa para a não subsunção dos fatos à norma penal incriminadora, já que o Ministro entendeu que o habeas corpus exigia um tipo de subsunção em concreto do fato-norma, sendo o fato a prática ou não de racismo, a qual implicava a solução prévia do conflito de princípios, ou seja, seria preciso saber-se concretamente se Ellwanger havia abusado - ofendendo a dignidade humana dos judeus - ou não da sua liberdade de expressão, para a caracterização ou não de sua conduta como racismo.

Portanto, consoante entendeu Ayres Britto, a demanda trazia à tona o tema da contraposição de princípios jurídicos. Para a solução deste problema, O Ministro postulou a necessidade de esforço para se demarcar o campo de expressão de cada princípio, evitando-se o concreto sacrifício de um deles e, não sendo possível, defendeu que a preferência deveria recair na norma-princípio que melhor assegurasse aplicabilidade de outras também relacionadas ao preâmbulo, aos fundamentos (Art. $1^{\circ}, \mathrm{I}$ a V) e aos objetivos fundamentais (Art. $3^{\circ}$, I a IV) da Constituição Federal.

Com isso, o Ministro ressaltou a diferença entre uso e abuso da liberdade de expressão, a primeira salvaguardada constitucionalmente, enquanto a segunda enseja, do ponto de vista da 'vítima', o direito de resposta e de desencadear o processo de apuração de abusividade - aferível casuisticamente e, portanto, a posteriori - para responsabilização civil e até mesmo penal do agente.

No entanto, Ayres Britto propôs como excludentes constitucionais da abusividade a crença religiosa, a convicção filosófica e a convicção política (art. $5^{\circ}$, VIII da CF) o que garantiria, nesses três casos, um reforço constitucional à liberdade de expressão.

Naturalmente que, assim entendendo, o Ministro reforçou que Ellwanger manteve-se em seu exercício de liberdade de expressão, com especial tutela constitucional e, resolvido o aparente conflito de princípios pela prevalência da liberdade de expressão, Ayres Britto concluiu que a conduta de Ellwanger não se subsumia à prática de racismo e tampouco a qualquer outro tipo penal, razão porque deferiu o habeas corpus de ofício, concedendo a ordem para absolvê-lo. 


\subsection{Voto do Ministro Marco Aurélio Mello}

Em seu voto, o Ministro Marco Aurélio Mello tomou como objeto central o conflito de princípios, com ênfase à liberdade de expressão. Embora tenha passado pelo problema semântico de se saber se o termo racismo abrangeria o antissemitismo, o Ministro erigiu o conflito de princípios como o cerne do problema, considerando o caso como um julgamento histórico, especialmente quanto à liberdade de expressão.

À questão por ele levantada sobre a possibilidade de a publicação de livro com conteúdo que revele ideias preconceituosas e antissemitas consistir em prática de racismo e se havia dados concretos que demonstrem isso, Marco Aurélio respondeu negativamente, por entender que o caso era de defesa de ideologia, o que não seria crime, já que o livro de Ellwanger exporia visão deturpada de um fato histórico, mas sem caracterizar incitação à violência.

Por tal razão, embora entendesse que o livro evidenciava claro preconceito de Ellwanger contra os judeus, defendeu que não caracterizaria racismo, até mesmo pelo contexto histórico-social, já que, diferentemente do preconceito contra negros ou mesmo nordestinos, que ensejariam em sua opinião mais chance de representar ameaça real à dignidade de tais grupos pela possibilidade de encontrar adeptos a tais pensamentos no Brasil, em relação ao povo judeu, o livro não ensejara hipótese de dano real, mas seria perigo meramente aparente.

Assim, para Marco Aurélio, o que caracterizaria o crime de racismo seriam práticas panfletárias que efetivamente incitassem o ódio aos judeus com dizeres tais como "morte aos judeus" ou "expulsão aos judeus", não sendo o caso de Ellwanger, que teria publicado o livro com ideias sobre a relação entre judeus e alemães na Segunda Guerra Mundial.

Até mesmo porque, o Ministro Marco Aurélio apontara que a determinação constitucional de imprescritibilidade do crime de racismo se trataria de manifestação de simbolismo ${ }^{274}$, por refletir exceção às garantias dos direitos fundamentais, considerada a imprescritibilidade tanto por constitucionalistas como por penalistas uma figura excepcional prevista em sede constitucional para o crime de racismo apenas na Constituição de 1988 e não

\footnotetext{
${ }^{274}$ Ao se referir à jurisprudência simbólica, Marco Aurélio explica-se dizendo que: "É que o Tribunal [STF], à medida que venha a relativizar a garantia da liberdade de expressão, enquadrando como manifestação racista o livro de autoria do paciente, bem como as publicações de que fora editor, terminará por praticar função simbólica, implementando uma imagem politicamente correta perante a sociedade". BRASIL. Supremo Tribunal Federal. Habeas Corpus $\mathrm{n}^{\mathrm{o}}$ 82.424-2/RS. Ministro Relator Moreira Alves. Ministro Relator para o Acórdão Maurício Corrêa. Julgado em 17.09.2003. D.J. 19.03.2004. Disponível em: <http://redir.stf.jus.br/paginadorpub/paginador.jsp?docTP=AC\&docID=79052>. Acesso em: 21 out. 2011.
} 
nas anteriores -, reservada a crimes gravíssimos e de maior lesividade como crimes de guerra, assim definidos pelo Estatuto do Tribunal Militar Internacional de Nuremberg e os contra a humanidade, cometidos em tempo de guerra ou de paz.

Daí porque, segundo Marco Aurélio, a interpretação do Art. $5^{\circ}$, XLII da CF deveria ser o mais limitada possível, de modo que a imprescritibilidade incidisse apenas em casos de discriminação racista contra negro - tendo-se, inclusive, em vista o intuito da Assembleia Constituinte de buscar o combate à discriminação racial contra o negro, o que teria inspirado a elaboração da emenda aditiva que inseriu a norma do dispositivo supracitado, tomando-se essa base inicial da discussão do Constituinte como meio para não se ampliar ou tornar abertas as cláusulas restritivas da eficácia dos direitos fundamentais, como a do dispositivo, ao prever a imprescritibilidade.

No entanto, o Ministro apontou que a verdadeira questão constitucional do caso seria o problema da colisão entre a liberdade de expressão e a dignidade do povo judeu, sendo necessária a ponderação para se determinar a limitação da liberdade de expressão pela alegada prática de discurso preconceituoso atentatório à dignidade de uma comunidade de pessoas ou se, ao contrário, haveria prevalência de tal liberdade.

Segundo o Ministro Marco Aurélio, a eficácia plena dos direitos fundamentais do Art. $5^{\circ}$ da $\mathrm{CF}$ e de outros direitos advindos de tratados internacionais (Art. $5^{\circ}, \S 2^{\circ}$ da $\mathrm{CF}$ ) é condição essencial para a consolidação e amadurecimento das instituições políticas e para a conservação e promoção da democracia, o que justificaria sua interpretação restritiva acima exposta, comungando com o entendimento do Ministro Moreira Alves.

Nesse sentido, considerou o direito fundamental à liberdade de expressão com dotado de extrema relevância e insuplantável nas suas facetas do direito de discurso, de opinião, de imprensa, à informação e proibição de censura, por possibilitar a participação democrática e funcionar como instrumento decisivo de controle da atividade governamental e do próprio exercício do poder, bem como uma proteção ao pensamento minoritário, impedindo o cerceamento da divulgação de ideias controversas, radicais e minoritárias.

No caso de Ellwanger, este teria utilizado sua livre manifestação e convicção política sobre o tema tratado, a livre expressão intelectual como escritor e autor (art. $5^{\circ}$, IV, VIII, XIII da CF). E, embora a liberdade de expressão não seja direito absoluto, mas limitável quanto ao exercício, em razão de sua dimensão social, não admitindo o abuso de liberdade de expressão pelo uso de meios violentos e arbitrários, não seria deste cunho a manifestação revisional de Ellwanger. 
Dessa forma, considerando que a solução tornava necessária a apreciação contextual, mediante o exame entre liberdade de expressão e proteção da dignidade humana não abstrata, mas concretamente, o Ministro partiu de questionamentos iniciais: se a liberdade de expressão estaria configurada, se o ato atacado estaria protegido por essa cláusula constitucional, se de fato a dignidade de determinada pessoa ou grupo estaria correndo perigo, se essa ameaça seria grave o suficiente a ponto de limitar a liberdade de expressão ou se, ao contrário, seria mero receio subjetivo ou uma vontade individual de que a opinião exarada não fosse divulgada, bem como se o meio empregado de divulgação de opinião representaria uma afronta violenta contra essa dignidade, entre outras questões.

Para a solução da colisão entre tais direitos fundamentais, Marco Aurélio buscou responder a essas perguntas recorrendo à aplicação do princípio da proporcionalidade, tendo em vista a semelhança de hierarquia dos valores em jogo: de um lado, a alegada proteção à dignidade do povo judeu; de outro, a garantia da manifestação do pensamento ou liberdade de expressão.

Com base no método da ponderação de Alexy, o Ministro questionou se a condenação de Ellwanger, a proibição de publicar seus pensamentos, a apreensão e a destruição das obras por ele editadas seriam meios adequados para acabar com a discriminação contra o povo judeu ou se teriam risco de incitar a discriminação, respondendo negativamente, pois entendera que a visão de Ellwanger dos fatos históricos não significava concordância dos leitores e, mesmo que concordassem, não significava que passariam a discriminar judeus.

Quanto ao questionamento sobre a necessidade da medida, ante a impossibilidade de aplicar outro meio menos gravoso a Ellwanger, Marco Aurélio entendeu que a medida não era necessária; ao contrário, seria necessário conceder a ordem, garantindo o direito à liberdade de manifestação do pensamento, preservando-se os livros, pois a restrição desse direito não garantiria a conservação da dignidade do povo judeu ${ }^{275}$.

Finalmente, à questão sobre se seria razoável dentro de uma sociedade plural como a brasileira restringir determinada manifestação de opinião por meio de livro - ao qual a maioria da população não tem acesso e apenas procurariam ler os efetivamente interessados -, ainda que preconceituosa ou despropositada, sob argumento de que incitaria prática de violência, a resposta foi negativa, considerando-se a inexistência de mínimos indícios de que o livro pudesse causar, no caso, o que o Ministro chamou de "revolução na sociedade".

\footnotetext{
${ }^{275}$ É questionável a motivação dessa arguição do Ministro, uma vez que o crime de racismo trata-se de crime formal, independente de resultado real que constitui, pois, mero exaurimento do crime.
} 
Assim, aplicando o princípio da proporcionalidade na hipótese de colisão da liberdade de expressão de Ellwanger e da dignidade do povo judeu, Marco Aurélio Mello entendeu que a condenação efetuada pelo Tribunal de Justiça do Estado do Rio Grande do Sul não foi o meio mais adequado, necessário e razoável, razão porque a ordem de habeas corpus, havia, segundo seu entendimento, de ser concedida.

\subsection{Voto do Ministro Sepúlveda Pertence:}

Em resumido voto, o Ministro Sepúlveda Pertence restringiu-se à questão semântica atinente à inteligência a partir do Art. 5, XLII da CF, da locução "prática de racismo", se abrangente ou não do antissemitismo.

O Ministro salientou que a negação da existência de raças não implicou esvaziamento do conteúdo da norma do citado dispositivo constitucional, até porque, caso contrário, seria crime impossível. E, distintamente dos Ministros Marco Aurélio e Moreira Alves, afastou-se de uma interpretação restritiva.

Embora tenha relevado que o objeto historicamente maior da proteção constitucional seria a clara preocupação brasileira com a discriminação contra o negro, alinhou-se à maioria dos julgadores, entendendo o conceito de raça como sociocultural e que o preconceito antissemita constituiria racismo, tanto na dicção do Art. $5^{\circ}$, XLII da CF, como na Lei $n^{\circ}$ 7.716/1989 e suas alterações.

O Ministro, em seu voto, lamentou a ampliação da discussão em razão de ter manifestado ao início do julgamento a preocupação com outra dimensão do caso, não inserida na limitação de sua fundamentação, relativa às implicações do caso no tema da liberdade de expressão, a partir de sua reflexão com base na Lei de Segurança Nacional do regime militar e em seus tipos abertos, tais como "fazer publicamente a propaganda subversiva", o que implicou sua dúvida sobre se livros poderiam ser instrumentos de crimes de instigação ou induzimento público de ódio racial.

Embora sua conclusão fosse de que, ressalvadas exceções, o livro não seria instrumento para tanto, mudou o posicionamento ao longo dos votos, passando a entender que um livro pode ser instrumento da prática de racismo, sendo a publicação de livro antissemita prática de racismo. 
Dessa forma, com base na solução do problema semântico - embora tenha enriquecido o caso com o levantamento sobre a liberdade de expressão, a qual não discutiu- o Ministro entendeu, com base em trechos do acórdão do Tribunal de Justiça do Rio Grande do Sul, com transcrição de expressões do livro e indícios da intenção de proselitismo de Ellwanger, pela prática de antissemitismo como de racismo, com consequente denegação da ordem de habeas corpus.

\subsubsection{Aplicação dos métodos e modelos}

\subsubsection{Aplicação do Método da subsunção}

Para a sistematização e delimitação do âmbito normativo do caso Ellwanger, identifica-se o UD como relativo à divulgação de ideias preconceituosas contra judeus e o UA $=[E]$ (o universo de ações refere-se a expressar opiniões). A pergunta cabível é: é permitido ou proibido expressar opiniões antissemitas?

A partir do Art. 20 da Lei no 7.716 de 05 de janeiro 1989, cujo Art. 20 dispõe, in verbis: "Praticar, induzir ou incitar a discriminação ou preconceito de raça, cor, etnia, religião ou procedência nacional. Pena: reclusão de um a três anos e multa" podem-se extrair as propriedades relevantes do caso: raça $(\mathrm{RA})$, cor $(\mathrm{C})$, etnia $(\mathrm{E})$, religião $(\mathrm{RE})$, procedência nacional (pn).

Como historicamente os judeus foram povo sem território e com a diáspora espalharam-se mundialmente, a propriedade procedência nacional deixa de ser relevante para o caso. Também a cor não é um elemento determinante quando se fala em preconceito contra judeu, se racial ou não, pois o que se discute quanto à acepção do termo judeu é se são raça, etnia ou religião.

Portanto, embora haja cinco elementares disjuntivas (posto não ser preciso constatá-las simultaneamente) do tipo acima referidas, para o caso há apenas três propriedades relevantes: raça, etnia ou religião. Sendo o número de casos correspondente ao resultado da aplicação da formula $2^{\text {n }}$, em que ' $n$ ' é o número de propriedades relevantes, tem-se: $2^{3}$ casos $=8$ casos: 


\begin{tabular}{|l|l|l|l|}
\cline { 2 - 4 } \multicolumn{1}{c|}{} & RA & E & RE \\
\hline 1 & + & + & + \\
\hline 2 & + & - & + \\
\hline 3 & + & + & - \\
\hline 4 & + & - & - \\
\hline 5 & - & + & + \\
\hline 6 & - & + & - \\
\hline 7 & - & - & + \\
\hline 8 & - & - & - \\
\hline
\end{tabular}

Com base nisso, pode-se construir o seguinte sistema normativo com as soluções deônticas obtidas a partir da interpretação do dispositivo acima indicado:

\begin{tabular}{|l|l|l|l|l|}
\cline { 2 - 5 } \multicolumn{1}{c|}{} & RA & E & RE & SN \\
\hline 1 & + & + & + & Phe \\
\hline 2 & + & - & + & Phe \\
\hline 3 & + & + & - & Phe \\
\hline 4 & + & - & - & Phe \\
\hline 5 & - & + & + & Phe \\
\hline 6 & - & + & - & Phe \\
\hline 7 & - & - & + & Phe \\
\hline 8 & - & - & - & Pe \\
\hline
\end{tabular}

A partir desse sistema, nota-se que a ação de se expressar livremente será permitida apenas se não houver ofensa de ordem racial, étnica ou religiosa. Por essa razão, a discussão levantada no acórdão no caso Ellwanger se judeus constituem raça, etnia ou religião, não tem repercussão na solução normativa do caso, pois sendo quaisquer deles - não importando exatamente qual dos três -, será vedada a expressão de cunho ofensivo.

Inclusive, como o crime de racismo é considerado crime formal, tampouco importa que o resultado constante dos núcleos induzir ou incitar ocorra pragmaticamente (e até por esse motivo o Ministro Ayres Britto sintetiza os núcleos do tipo a praticar, independentemente do resultado final da conduta). 
Só se permitirá, pois, expressar-se livremente se não houver preconceito nem de raça, nem de etnia ou religião, do contrário é proibida a livre expressão, ainda que não venha a efetivamente incitar ódio. Portanto, a solução semântica da acepção do termo judeu bastaria para resolver o caso se não se reconhecesse o conflito de princípios subjacente.

Assim, se é considerado que as ideias de Ellwanger relativamente aos judeus constituem preconceito de raça, etnia ou religião, sua conduta subsume-se ao tipo e é, portanto, proibida, de modo que está justificada sua condenação. Caso não se enquadre judeu como raça, nem etnia, nem religião, a conduta de Ellwanger é permitida e, portanto, não se subsume ao tipo, de modo que não é lícita a condenação e a ordem de habeas corpus deve ser deferida.

Resta, portanto, à luz do direito interno, como se expôs na síntese do caso, saber-se se judeu pode ser considerado raça ou etnia ou religião. Já não é o caso quando se alude ao Direito Internacional, tal como fez Celso Lafer, na condição de amicus curiae, ao apontar que as normas de direito internacional relativas a direitos humanos, devem ser relevadas na interpretação do direito interno. E entre as referidas normas consagra-se como racismo o antissemitismo $^{276}$.

Portanto, independentemente de saber se judeu se enquadra na categoria de raça, etnia ou religião, à luz do Direito Internacional Público, o caso está subsumido ao Art. $5^{\circ}$, LXII da CF que prevê a imprescritibilidade do crime de racismo. Assim, a conjugação do Art. 20 da Lei $n^{\circ} 7.716 / 89$, alterado pela Lei $n^{\circ} 8.081 / 90$, ao Art. 5º , LXII da CF, leva, no caso, à seguinte norma (resultante, já, de processo interpretativo): "incitar ódio contra judeus é crime de racismo com punibilidade imprescritível”. No caso, Ellwanger incitou ódio contra judeus. Logo, não se deve deferir a ordem de habeas corpus a Ellwanger, pois não está prescrita a pena a que foi condenado.

A solução acima, no entanto, é deveras simplista e oculta os diversos e complexos elementos envolvidos no julgamento. Primeiramente, a definição semântica do conceito de racismo se abrangente ou não do antissemitismo perpassou todo o julgamento, o que demonstra que a construção da premissa maior é processo assaz intricado. Ainda, esta solução é representativa da decisão como um todo do Tribunal, sem as nuanças dos votos.

Ela não capta, por exemplo, o conflito de princípios notado em especial por dois dos onze Ministros. Tampouco apresenta a divergência ocorrida no caso, visto que, se na

\footnotetext{
${ }^{276}$ No original, conforme refere Celso Lafer, consta do item 17 da Resolução "incidents of contemporary forms of racism and racial discrimination, inter-alia, against blacks, Arabs and Muslins, xenophobia, Negrophobia, anti-Semitism and related intolerance". LAFER, Celso. O caso Ellwanger: anti-semitismo como crime da prática do racismo. Revista de Informação Legislativa, Brasília, a. 41, n. 162, p. 53-89, abr./jun. 2004, p. 58.
} 
construção da premissa maior tem-se em vista apenas o ordenamento pátrio e não os dispositivos de Direito Internacional Público, tal como o fez o Ministro Moreira Alves, a solução é em sentido diverso: pela não subsunção do caso ao tipo legal, nem à imprescritibilidade constitucional. Neste caso, a norma já seria outra: "incitar ódio contra judeus não constitui racismo, sendo prescritível a pena deste crime".

O que denota tanto o fato ao início apontado de que a subsunção não é método mecanicista que assegure real certeza e segurança, e, por outro lado, que apresenta limitações, sobretudo quanto à assimilação de conflitos éticos e sociais envolvidos no processo adjudicatório. Também leva a resultados, mas nem sempre permite que se justifique a diversidade das soluções obtidas, visto que oculta premissas decisórias. E, aqui, a coerência, consoante a seguir se explanará também não garante solução única, mas permite justificar as soluções, mesmo contraditórias, tendo-se em vista as pautas legais adotadas.

\subsubsection{Aplicação do Método da Ponderação}

Consoante anteriormente exposto, nem todos os Ministros do STF reconheceram o conflito de princípios. Para os que se restringiram à questão semântica, como Moreira Alves, Ellen Gracie e Nelson Jobim, a solução do caso deu-se por via dedutiva mediante a aplicação do método de subsunção que, curiosamente, levou os Ministros a decisões antitéticas, o primeiro no sentido da não subsunção, e os dois últimos na subsunção à norma e reconhecimento do crime de racismo e de sua imprescritibilidade.

Os Ministros Celso de Mello e Carlos Velloso, embora tenham reconhecido a possibilidade de conflito de princípios em casos concretos, entenderam não ser o caso de Ellwanger, uma vez que a liberdade de expressão não abarcaria o direito de ofensa e, portanto, a dignidade humana já estaria constitucionalmente sobreposta à liberdade de expressão em casos de manifestações racistas.

Embora se refiram ao conflito de princípios, Cezar Peluso e Maurício Corrêa não entram no mérito de tal conflito. Já Ayres Britto, embora inicialmente reconheça o conflito de princípios, muda de orientação para desconsiderar que haja real ofensa à dignidade de judeus e consagrar que o caso trata-se apenas de exercício de liberdade de expressão, não se podendo sequer falar de crime. 
Já os Ministros Gilmar Mendes e Marco Aurélio Mello além de reconhecerem o conflito de princípios, erigem-no como principal problema a ser resolvido e evocam o método da ponderação como o adequado para sua solução. No entanto, nenhum dos Ministros aplica o método tal como efetivamente proposto por Alexy - com a demonstração do resultado pelo emprego da fórmula de peso - e a ponderação por eles efetuada leva a soluções díspares. Daí se notar ser válida uma análise mais detida de suas decisões.

Em seu voto, o Ministro Gilmar Mendes parte da premissa de que não há princípios ou valores absolutos, e até por isso se justificaria a aplicação do princípio da proporcionalidade que, para ele, é sinônimo do princípio do devido processo legal em sentido substantivo ou da proibição do excesso, de modo a se estabelecer um 'limite do limite' ou 'proibição do excesso' na restrição de direitos fundamentais, como já referido. Assim, como propõe Alexy, o Ministro entende que a máxima da proporcionalidade determina o limite último da possibilidade de restrição legítima de determinado direito fundamental.

Adotando esse pressuposto e reconhecendo no caso o conflito concreto entre, de um lado, a liberdade de expressão de Ellwanger e, de outro, a dignidade de judeus, que teria sido afetada pelas manifestações discriminatórias antissemitas de Ellwanger, o Ministro entende o método da ponderação como adequado e racional para a solução do conflito de princípios ${ }^{277}$ que, no caso, estão constitucionalmente amparados e não são hierarquizados, sendo mister a aplicação do princípio da proporcionalidade no caso concreto, para sua solução, por meio da análise das três máximas parciais do método da ponderação: a apreciação da adequação, da necessidade e da ponderação em sentido estrito.

Para ao exame fático da adequação e da necessidade, é preciso o estabelecimento de qual a medida adotada no caso e qual o fim almejado. A medida reconhecida pelo Ministro Gilmar Mendes é a condenação de Ellwanger pela prática de racismo contra judeus, determinada em sede recursal pelo Tribunal de Justiça do Rio Grande do Sul e corroborada

\footnotetext{
277 Segundo o Ministro Gilmar Mendes: “... as exigências do princípio da proporcionalidade representam um método geral para a solução de conflitos entre princípios, isto é, um conflito entre normas que, ao contrário do conflito entre regras, é resolvido não pela revogação ou redução teleológica de uma das normas conflitantes nem pela explicitação de distinto campo de aplicação entre as normas, mas antes e tão-somente pela ponderação do peso relativo de cada uma das normas em tese aplicáveis e aptas a fundamentar decisões em sentidos opostos. Nessa última hipótese, aplica-se o princípio da proporcionalidade para estabelecer ponderações entre distintos bens constitucionais". BRASIL. Supremo Tribunal Federal. Habeas Corpus no 82.424-2/RS. Ministro Relator Moreira Alves. Ministro Relator para o Acórdão Maurício Corrêa. Julgado em 17.09.2003. D.J. 19.03.2004. Disponível em: <http://redir.stf.jus.br/paginadorpub/paginador.jsp?docTP=AC\&docID=79052〉. Acesso em: 21 out. 2011.
} 
pelo Superior Tribunal de Justiça. Quanto ao fim, o Ministro entende que a finalidade de tal medida é a salvaguarda de uma sociedade pluralista e tolerante ${ }^{278}$.

No que diz respeito à adequação da medida para alcançar tal fim, Mendes postula que a decisão do TJRS vai ao encontro da posição do Estado de defender a dignidade da pessoa humana (art. $1^{\circ}$, III da CF), o pluralismo político (Art. $1^{\circ}, \mathrm{V}$ da $\mathrm{CF}$ ) e outros objetivos e valores como o repúdio ao terrorismo e ao racismo nas relações internacionais (Art. $4^{\text {o }}$, VIII, $\mathrm{CF}$ ), bem como se conforma à norma constitucional que normatiza o racismo como crime imprescritível (Art. 5, LXII, CF). Embora o Ministro entenda ser evidente que a medida condenatória fosse adequada, não buscou demonstrar a adequação defendida e tampouco se esta seria a medida mais adequada dentre as eventualmente possíveis ${ }^{279}$.

No concernente à necessidade da medida, Gilmar Mendes registra que é 'indubitável' que a condenação fora medida necessária, por entender que não existia outro meio menos gravoso e igualmente eficaz para atingir o fim colimado, até mesmo tendo-se em vista que, para a tutela da dignidade, o próprio constituinte determinara a criminalização e a imprescritibilidade da prática do racismo, de modo que não haveria exorbitância no acórdão do TJRS. Também nesse aspecto o Ministro não se ocupou de buscar com maior rigor a demonstração da necessidade da medida.

Quanto ao exame da ponderação em sentido estrito, embora o Ministro tenha dito ter efetuado tal apreciação, ele apenas apresenta o resultado obtido, mas não demonstra sua efetivação, uma vez que não aplica a fórmula de peso e não revela os pesos efetivamente atribuídos a cada princípio. Por essa razão, vale apreciar os argumentos do Ministro para que, a partir deles, se possa inferir estipulativamente o peso atribuído a cada princípio.

Tal como o Ministro Ayres Britto, o Ministro Gilmar Mendes toma a liberdade de expressão como pedra angular do próprio sistema democrático. No entanto, distintamente daquele, que considera as expressões de Ellwanger como não atentatórias à dignidade e simples expressões de orientação ideológica e opinião pessoal, Gilmar Mendes defende que,

\footnotetext{
${ }^{278}$ No fim de seu voto, o Ministro amplia esse rol ao salientar a proporcionalidade entre a conduta de Ellwanger e a condenação do Tribunal de Justiça do Rio Grande do Sul, reiterando que a colisão de direitos fundamentais deve ser resolvida casuisticamente, dizendo tê-lo feito no caso Ellwanger, para concluir que prevalece a posição do Estado no sentido de defender os fundamentos da dignidade da pessoa humana (art. $1^{\circ}$, III da CF) e o pluralismo político (art. $1^{\circ}, \mathrm{V}$ da $\mathrm{CF}$ ), repúdio ao terrorismo e ao racismo regente do Brasil nas relações internacionais (art. $4^{\circ}$, VIII da $\mathrm{CF}$ ) e a norma constitucional que estabelece a imprescritibilidade do racismo (Art. $5^{\circ}$, XLII da CF).

${ }^{279}$ Aqui se poderia cogitar de mera sanção civil ou administrativa de ordem mandamental, com o objetivo, por exemplo, de se impor sanção pecuniária, ou mandamental pela obrigatoriedade de retratação pública e/ou retirada das obras de livrarias, para, ao menos, reduzir a circulação da mensagem. Nesse sentido, fora a decisão no caso da modelo Daniella Cicarelli, em que foi determinada a retirada de vídeo em que a modelo aparecia em situação constrangedora, levadas a público em sítio da rede mundial de computadores.
} 
apesar de ter significado inexcedível para o sistema democrático, a liberdade não alcança a intolerância racial e o estímulo à violência, o que o Ministro reforça que foi constatado no caso Ellwanger segundo o acórdão condenatório do TJRS.

Gilmar Mendes expõe a preocupação em sociedades democráticas com o exercício da liberdade de expressão consistente na incitação à discriminação racial, uma vez que esta comprometeria a ideia de igualdade, também um dos pilares do sistema democrático, que dá, inclusive, especial relevo a este princípio da igualdade, com potencial de entrar em tensão dialética com a liberdade de expressão, tornando necessária a aplicação do princípio da proporcionalidade.

Assim, para Mendes, a liberdade de expressão, não sendo direito absoluto, deve se compatibilizar com o direito à imagem, à honra e à vida privada, tal como na tutela constitucional (CF, Art. 5 $\mathrm{X})$, sendo legítima, pois, a intervenção legislativa para harmonizar valores constitucionais eventualmente em conflito, de forma que a liberdade de expressão permitida e salvaguardada seria a que não levasse à intolerância, ao racismo, em prejuízo da dignidade humana, do regime democrático e dos valores inerentes à sociedade pluralista.

Concluindo que as obras editadas e as escritas por Ellwanger não são obras revisionistas da história, como alegado pela defesa, mas portadoras de ideias que atentam contra a dignidade dos judeus, Mendes reconhece que o caso não seria de simples discriminação, mas de racismo, uma vez que os textos estimulariam ódio e violência contra os judeus e, inobstante, o TJRS agira, a seu ver, com cautela na dosagem da pena, atendendo ao princípio da proibição do excesso.

A decisão se justificaria, porque a discriminação racial levada a efeito pelo exercício da liberdade de expressão ${ }^{280}$ também compromete, segundo Mendes, um dos pilares do sistema democrático, a própria ideia de igualdade, como exposto.

A partir dessa linha de argumentação, o Ministro estabelece as pautas quanto ao princípio da dignidade humana ao expor que "não se pode atribuir primazia absoluta à liberdade de expressão, no contexto de uma sociedade pluralista, em face de valores outros

\footnotetext{
${ }^{280}$ No caso, Mendes parece não ter considerado como propriedades relevantes a veracidade ou não da das ideias de Ellwanger ou a existência ou não de relevância pública dessa informação, tendo-se atido, sobretudo, aos princípios da dignidade e da liberdade, independentemente das circunstâncias concretas aludidas. A regra final por ele estabelecida para a decisão do caso seria de que a dignidade prevalece sobre a liberdade de expressão se a ideia é racista. Para a visualização de uma análise em que as circunstâncias concretas são relevadas, vide: ZORRILlA, David Martínez. Conflictos Constitucionales, Ponderación e Indeterminación Normativa. Madrid: Marcial Pons, 2007, p. 205-207.
} 
como os da igualdade e da dignidade humana" ${ }^{, 281}$, o que viria a justificar as normas do Art. $5^{\circ}$, incisos XLI e XLII da CF. Com isso, a decisão do TJRS atenderia ao requisito da proporcionalidade em sentido estrito: proporção entre o objetivo perseguido de preservar valores inerentes a uma sociedade pluralista, da dignidade humana, e o ônus imposto à liberdade de expressão de Ellwanger.

Embora não tenha deixado explícito em seu voto, o trecho supracitado permite inferir que o Ministro considerou alta ou grave a importância de se satisfazer o princípio da dignidade, afetado pela prática de racismo, e leve ou baixa a importância de se satisfazer no caso o princípio da liberdade de expressão, justamente por seu conteúdo antissemita.

Tendo-se em vista as variáveis da fórmula de peso de Alexy, o grau de intervenção em um princípio e a importância de se satisfazer o outro, e acrescentando-se as demais variáveis do peso abstrato - que no caso poderia ser desconsiderada ${ }^{282}$ - e a certeza quanto à afetação concreta do princípio em análise, teríamos no caso Ellwanger, a partir dos argumentos do Ministro Gilmar Mendes, que a intervenção na dignidade (d) seria considerada como grave $\left(\operatorname{IdC}^{283}=4\right)$ e o peso abstrato da dignidade também considerado como sério $(\mathrm{WdA}=4)$, havendo certeza quanto à afetação da dignidade de judeus, em razão das ideias discriminatórias antissemitas $(\mathrm{SdC}=1)$.

Por outro lado, a satisfação da liberdade de expressão (e) seria considerada como moderada $(\mathrm{IeC}=2$ ), seu peso abstrato seria equiparado ao da dignidade e também seria considerado como sério $(\mathrm{WeA}=4)$, até mesmo, pelo status constitucional privilegiado de que gozam, e a segurança das premissas quanto à sua afetação (afetação à liberdade de expressão de Ellwanger em razão da condenação) seria considerada como moderada, sobretudo, porque não houve censura prévia $(\mathrm{SeC}=0,5)$.

Essas considerações estipulativas, transpostas na fórmula de peso entre o direito à dignidade dos judeus e a liberdade de expressão de Ellwanger, que seguiria o modelo: GPd,eC $=\underline{\mathrm{IPdC}} \cdot \mathrm{WPdA} . \mathrm{SPdC} / \mathrm{WPeC} . \mathrm{WPeA} . \mathrm{SPeC}$, levaria ao seguinte resultado:

\footnotetext{
281 BRASIL. Supremo Tribunal Federal. Habeas Corpus n ${ }^{\circ}$ 82.424-2/RS. Ministro Relator Moreira Alves. Ministro Relator para o Acórdão Maurício Corrêa. Julgado em 17.09.2003. D.J. 19.03.2004. Disponível em: <http://redir.stf.jus.br/paginadorpub/paginador.jsp?docTP=AC\&docID=79052>. Acesso em: 21 out. 2011.

${ }^{282}$ A liberdade de expressão está inserida no título constitucional dos direitos e garantias fundamentais (Art. $5^{\circ}$, IV da CF), e a dignidade da pessoa humana entre os princípios fundamentais da República (Art. $1^{\circ}$, III da CF), de modo que dizem respeito a preceitos basilares do ordenamento jurídico pátrio. Com isso, os pesos abstratos desses princípios seriam coincidentes, não se podendo estabelecer hierarquia ou maior peso a qualquer de tais princípios, tal como o próprio Ministro considera ao asseverar como pedras angulares do sistema democrático a liberdade de expressão e a igualdade, esta afetada por práticas racistas tanto quanto a dignidade humana. Portanto, o resultado desse cálculo de pesos abstratos seria igual a 1, não interferindo no resultado.

${ }^{283}$ Relembre-se que a intervenção em um princípio e a certeza de sua afetação são aferidas concretamente, daí o $\mathrm{C}$ das fórmulas (PdC e $\mathrm{SdC}$ ), diferentemente do peso que entra na fórmula - que é abstrato (A), WdA - para se chegar ao peso concreto de um princípio em relação ao outro.
} 


$$
\mathrm{GPd}, \mathrm{eC}=\frac{\mathrm{IPdC} \cdot \mathrm{WPdA} \cdot \mathrm{SPdC}}{\mathrm{WPeC} \cdot \mathrm{WPeA} \cdot \mathrm{SPeC}}=\mathrm{GPd}, \mathrm{eC}=\frac{4 \times 4 \times 1}{2 \times 4 \times 0,5}=\frac{16}{4}=4 .
$$

Assim, sendo o peso concreto da dignidade em relação à liberdade de expressão superior a 1, deve prevalecer a dignidade e, portanto, justifica-se a condenação efetuada pelo TJRS. Logo, para se chegar ao resultado logrado pelo Ministro Gilmar Mendes pressupõe-se terem sido esses os pesos por ele atribuídos a cada princípio e essa sua ponderação em sentido estrito que justificasse sua decisão.

No entanto, impende considerar no tópico também o voto do Ministro Marco Aurélio que, tanto quanto o Ministro Gilmar Mendes, reconhece no caso o conflito de princípios, e igualmente alude e recorre ao método da ponderação para solucionar o caso concreto, mas atingindo resultado antagônico.

O Ministro Marco Aurélio inicia seu voto de modo bastante similar ao Ministro Gilmar Mandes. Marco Aurélio reconhece como a verdadeira questão constitucional do caso, o conflito ente liberdade de expressão e dignidade, como um problema intrincado que exige ponderação de valores.

Quanto à liberdade de expressão, o Ministro a considera como princípio de extrema relevância, insuplantável nas suas facetas do direito de discurso, de opinião, de imprensa, o que já faz notar que a importância concreta da satisfação desse princípio, em seu sentir, é alta ou, mais precisamente, muito alta. Isso porque o Ministro entende que a liberdade de expressão possibilita a participação democrática, serve como instrumento decisivo de controle da atividade governamental e do próprio exercício do poder, o que justifica a necessidade de especial atenção a tal princípio.

Igualmente, considera que a liberdade de expressão é garantia também do controle do poder econômico, por permitir evitar-se o abuso e a venda de ideologia de grupos econômicos dominantes. E, em última análise, o direito fundamental à liberdade de expressão seria "uma trincheira do cidadão contra o Estado", especialmente quando se divulguem ideias controversas, radicais ou minoritárias, ou seja, desproporcionais em relação ao pensamento da maioria.

No entanto, tal como demais direitos fundamentais, cuja eficácia plena é, para ele, condição essencial para a consolidação e amadurecimento das instituições políticas e para a conservação e promoção da democracia, o Ministro Marco Aurélio salienta que a liberdade de expressão não é um direito absoluto, até mesmo por encontrar limites nos demais direitos fundamentais, o que poderia gerar a colisão de princípios, como constatou no caso, e, com 
respaldo na teoria de Alexy, à necessária 'ponderação' entre os princípios colidentes, a qual possibilitasse um meio-termo entre a vinculação e a flexibilidade dos direitos, tendo-se em vista o caso concreto e as circunstâncias da hipótese, para se aferir qual direito teria $\operatorname{primazia}^{284}$.

Não obstante, no caso de Ellwanger, o Ministro Marco Aurélio salienta que deve estar provado o risco ou o abuso que justifique a limitação da liberdade de expressão e que não bastam expectativas abstratas ou receios pessoais de que ideias antissemitas venham a levar ao ódio racial, sem exame de elementos sociais e culturais ou indícios na história bibliográfica de efetiva discriminação contra judeus no Brasil.

Até mesmo, porque, segundo o Ministro, o qual atribui às circunstâncias concretas da realidade pátria especial relevo em sua decisão, configurariam crime de racismo apenas expressões de apologia ou real incitação, tais como: "morte aos judeus" ou "expulsão aos judeus", como anteriormente citado; o que não seria o caso de Ellwanger que, a seu ver, apenas exprimiu uma opinião, ainda que controversa e discrepante do esperado em relação ao homem médio. Ou seja, entende que Ellwanger apenas usou sua livre manifestação, exprimindo uma convicção política sobre o tema tratado, com respaldo em sua livre expressão intelectual como escritor e autor (art. $5^{\circ}$, IV, VIII, XIII da CF).

Ao distinguir entre preconceito e discriminação, Marco Aurélio entende ser o primeiro de cunho teórico e ideológico, enquanto a discriminação ou racismo é a concreção das ideias em práticas ofensivas. Para ele, a publicação de Ellwanger, sendo mera expressão ideológica, constituiria apenas preconceito, e não racismo.

Ademais, propõe que a defesa de uma ideologia não é crime, ainda que a obra cause repúdio, pois o cerne da discussão no caso não seriam campos de extermínio ou pensamento de supremacia da raça ariana, mas a possibilidade de Ellwanger de manifestar seu ponto de vista e de outrem por meio de livros.

Desse modo, o Ministro ventila a questão do meio; no caso, a expressão de ideias antissemitas em livros que, para ele, expõem visão deturpada de um fato histórico, mas sem

\footnotetext{
${ }^{284}$ Como salienta o Ministro em seu voto: "Dessa forma, não é correto se fazer um exame entre liberdade de expressão e proteção da dignidade humana de forma abstrata e se tentar extrair daí uma regra geral. É preciso, em rigor, verificar se, na espécie, a liberdade de expressão está configurada, se o ato atacado está protegido por essa cláusula constitucional, se de fato a dignidade de determinada pessoa ou grupo está correndo perigo, se essa ameaça é grave o suficiente a ponto de limitar a liberdade de expressão ou se, ao contrário, é um mero receio subjetivo ou uma vontade individual de que a opinião exarada não seja divulgada, se o meio empregado de divulgação de opinião representa uma afronta violenta contra essa dignidade, entre outras questões". BRASIL. Supremo Tribunal Federal. Habeas Corpus $\mathrm{n}^{\circ}$ 82.424-2/RS. Ministro Relator Moreira Alves. Ministro Relator para o Acórdão Maurício Corrêa. Julgado em 17.09.2003. D.J. 19.03.2004. Disponível em: <http://redir.stf.jus.br/paginadorpub/paginador.jsp?docTP=AC\&docID=79052>. Acesso em: 21 out. 2011.
} 
caracterizar incitação à violência. Também na apreciação da relevância do meio, as circunstâncias concretas são consideradas como fatores determinantes: o Ministro enfatiza que, diferentemente de outros meios, como o uso de alto-faltantes, por exemplo, o livro não é acessado senão por quem deseje e, ademais, o Brasil não é povo de leitores, como regra.

Por isso, o Ministro, considerando como questão de fundo do habeas corpus a possibilidade de a publicação de um livro com conteúdo que revele ideias preconceituosas e antissemitas haver instigado ou incitado a prática de racismo contra judeus, a resposta é de que não há dados concretos que demonstrem isso e, ao contrário, concretamente, na realidade brasileira, não haveria tal potencial de instigar ódio racial contra judeus e ofender-lhes a dignidade.

O que seria, para Marco Aurélio, diferente, por exemplo, em relação a um livro preconceituoso contra o negro, ou até mesmo contra o nordestino, caso que teria mais chance de representar ameaça real à dignidade daqueles povos, pela possibilidade de se encontrar adeptos a tais pensamentos no Brasil. De modo que, quanto aos judeus, não haveria hipótese de dano real e o livro de Ellwanger, bem como os por ele editados, constituiriam exercício profissional assegurado constitucionalmente, resguardando-se no caso, a liberdade de expressão.

Assim, para a solução do conflito entre a liberdade de expressão de Ellwanger e a dignidade dos judeus, o Ministro Marco Aurélio estriba-se na teoria de Alexy, postulando a aplicação do princípio da proporcionalidade como mecanismo eficaz para a ponderação exigida no caso concreto, tendo-se em vista a mesma hierarquia dos valores em jogo, selando, portanto, como iguais os valores abstratos dos princípios em caso.

Para a aplicação das três máximas parciais do método da ponderação, e mais especificamente, para a análise fática da adequação e da necessidade, o Ministro identifica como a medida a se apreciar a condenação de Ellwanger pelo TJRS e os efeitos desta - a proibição de publicar pensamentos, a apreensão e a destruição das obras editadas; e como fim de tal medida, o de acabar com a discriminação ${ }^{285}$.

A resposta do Ministro é de que a medida não é adequada a tal fim, pois a transmissão por Ellwanger de sua versão da História não implicaria concordância necessária dos leitores e,

\footnotetext{
${ }^{285}$ Gilmar Mendes pergunta-se sobre a proporcionalidade entre a conduta e a condenação. Já Marco Aurélio pergunta-se sobre a proporcionalidade entre a incriminação de Ellwanger e a apreensão e destruição de suas obras como meios adequados para acabar com a discriminação aos judeus; naturalmente, na forma como a esta pergunta é posta a resposta é negativa, pois não acabará com práticas antissemitas, mas no máximo as minorará. Assim, aqui, a postulação de tal 'fim', parece induzir o resultado: necessariamente a medida não é adequada ou suficiente para atingir esse fim, muito distante, mas um apenas a um fim mais palpável, como a coibição e não a extinção do racismo.
} 
mesmo que concordassem, não significaria que passariam a discriminar judeus. Por tal razão, a condenação e retirada das obras de Ellwanger seriam meios inadequados para se ceifar a discriminação contra judeus.

No referente à necessidade da medida, como escolha do meio mais suave, e considerando que a condenação de Ellwanger pelo TJRS fora medida desmesurada, havendo desproporcionalidade entre o meio e o fim, o Ministro Marco Aurélio defende que a condenação não é medida necessária e, ao contrário, por entender ser impossível se aplicar outro meio menos gravoso a Ellwanger, seria necessária a concessão da ordem, garantindo-se o direito à liberdade de expressão e preservando-se os livros, uma vez que defende que a restrição à liberdade de expressão não garante a conservação da dignidade do povo judeu.

Não obstante, em seu crivo, a medida não tenha passado pelo exame de necessidade, adentra na ponderação em sentido estrito, entendendo a medida como desproporcional. Assim, no exame da ponderação em sentido estrito, tal como o Ministro Gilmar Mendes, o Ministro Marco Aurélio não aplica a fórmula de peso para levar a cabo esse subprincípio.

O que Marco Aurélio questiona a respeito é se é razoável, dentro de uma sociedade plural como a brasileira, restringir a manifestação de opinião por meio de livro, ainda que preconceituosa ou despropositada, sob o argumento de que incitará a prática de violência, considerando-se que inexistem mínimos indícios de que o livro causará 'revolução' na sociedade brasileira ${ }^{286}$.

Nesse aspecto, Marco Aurélio salienta a existência de diversos livros escritos por autores já falecidos ${ }^{287}$ com conteúdo discriminatório e mesmo racista, cogitando sobre como se daria a responsabilização em tais casos e se as medidas também a eles se aplicariam. E aduz que não seria democraticamente legítimo ampliar ou tornar abertas as cláusulas restritivas da eficácia dos direitos fundamentais, o que justificaria dar o sentido mínimo possível ao conteúdo do inciso XLII do Art. $5^{\circ}$ da CF.

De modo que, ainda que preconceituosas e, mesmo, racistas à luz da legislação infraconstitucional, as manifestações de Ellwanger não poderiam ser abrangidas pela imprescritibilidade prevista na cláusula constitucional sobre racismo (Art. 5\%, LXII da CF), à qual o Ministro atribuiu caráter simbólico e de exceção às garantias dos direitos fundamentais, tal como o seria, em sua opinião, a decisão do STF ao manter a condenação, fazendo prevalecer a dignidade. Para Marco Aurélio, isso seria um exemplo de "Jurisprudência

\footnotetext{
${ }^{286}$ E aqui fica claramente notável o peso que o Ministro atribui às circunstâncias concretas, como fator determinante em sua decisão; a despeito de o crime de racismo ser um crime formal e, por conseguinte, de independer do resultado efetivo, que constitui mero exaurimento do tipo.

${ }^{287}$ Entre os quais cita "Minha Luta" de Hitler e "Os africanos no Brasil" de Nina Rodrigues.
} 
Simbólica", no sentido de se implementar uma imagem politicamente correta perante a sociedade, em contrariedade, por exemplo, com o Direito e a jurisprudência de Direito Comparado $^{288}$.

Assim, o Ministro conclui - embora sem a aplicação da fórmula de peso - que, atendendo ao princípio da proporcionalidade na hipótese de colisão da liberdade expressão de Ellwanger, de um lado, e a dignidade do povo judeu, de outro, a condenação efetuada pelo TJRS não fora o meio mais adequado, necessário e razoável para a salvaguarda da dignidade dos judeus.

A partir desses argumentos de Marco Aurélio, pode-se inferir que, para o Ministro, a intervenção na dignidade $(d)$ seria considerada como leve $(\operatorname{IdC}=1)$ e o peso abstrato da dignidade considerado como sério $(\mathrm{WdA}=4)$, havendo certeza, tendo-se em vista a realidade social e histórica brasileira e o meio da publicação, de não afetação da dignidade de judeus, em razão das ideias discriminatórias de Ellwanger $(\mathrm{SdC}=0,25)$.

Por outro lado, a intervenção na liberdade de expressão (e) e a necessidade de sua satisfação seriam consideradas como altas $(\mathrm{IeC}=4)$; seu peso abstrato seria equiparado ao da dignidade e também considerado como sério $(\mathrm{WeA}=4)$, porque igualmente a Gilmar Mendes, Marco Aurélio reconhece igual hierarquia constitucional entre os princípios em colisão. Quanto à segurança das premissas, no atinente à sua afetação (afetação à liberdade de expressão de Ellwanger em razão de sua condenação e das consequências desta) seria considerada como alta $(\mathrm{SeC}=1)$, ou para se usar de mais especificidade, poder-se-ia estipular, ante as considerações de Marco Aurélio, até mesmo como muito alta.

Transpondo-se os pesos presumivelmente atribuídos pelo Ministro Marco Aurélio para a fórmula de peso, tem-se o seguinte resultado:

$$
\mathrm{GPd}, \mathrm{eC}=\underline{\mathrm{IPdC} \cdot \mathrm{WPvA} \cdot \mathrm{SPvC}}=\mathrm{GPd}, \mathrm{eC}=\frac{1 \times 4 \times 0,25}{4 \times 4 \times 1}=\frac{1}{16}=0,0625 .
$$

Como o resultado obtido é inferior a 1 isso justifica a prevalência - explícita, a partir dos argumentos do Ministro e refletida nos pesos estipulativos inseridos na fórmula de peso, que levam ao resultado bastante discrepante, denotando a preponderância que o Ministro atribuiu à liberdade de expressão e a leve ou mínima relevância dada à dignidade dos judeus no caso - dada por Marco Aurélio à liberdade de expressão (que está no denominador da

\footnotetext{
${ }^{288}$ O Ministro registra, por exemplo, que decisões da Corte Constitucional Alemã consignaram que, no caso de haver conflito entre liberdade de expressão e honra a primeira deveria prevalecer. E, no caso, não seria diferente em relação à dignidade.
} 
fórmula). Isso justifica a decisão do Ministro Marco Aurélio de conceder a ordem de habeas corpus, por considerar desproporcional a condenação de Ellwanger pelo TJRS.

$\mathrm{O}$ que evidencia alguns aspectos dignos de nota: embora justifiquem suas decisões com recurso ao método da ponderação de Robert Alexy, os Ministros não aplicam a fórmula de peso que, segundo Alexy, é o demonstrativo da racionalidade desse procedimento, ao se atribuírem pesos e, destarte, chegar a resultado aritmético para o conflito de princípios.

Também se pode evidenciar a dificuldade no emprego desse método, já que dois Ministros que o invocam para fundamentar suas decisões chegam a resultados diametralmente opostos, notando-se que o método não permite uma conformação cabal das decisões ao ordenamento jurídico e, por outro lado, leva a uma indispensável apreciação estipulativa da decisão, a fim de se vislumbrar de que maneira a proposta alexyana foi concretizada, uma vez que os pesos não foram revelados, mas podem apenas ser presumidos a partir dos argumentos expostos.

Percebendo essa dificuldade, Oscar Vilhena questiona em sua obra, ao final da transcrição de trechos da decisão do caso Ellwanger "Como a aplicação do princípio da proporcionalidade por distintos Ministros pode gerar decisões tão díspares? Alguém errou na aplicação do referido princípio? Ou ele não é confiável?" 289 . O incômodo também é explicitado por Miguel Reale Junior ${ }^{290-291}$ :

Em suma, pode-se, desde já, inferir que a aplicação da máxima da proporcionalidade por via da análise das três máximas parciais, como diz Alexy, são importantes para dirigir, circunscrever, orientar a explicação da escolha, no caso concreto, acerca da primazia de um direito fundamental sobre outro. Contudo, o estudo da adequação da solução, da necessidade e da correspondência justa ao fim almejado não são suficientes para dotar este juízo de ponderação de objetividade, de certeza, pois, a cada intérprete uma

\footnotetext{
289 VIEIRA, Oscar Vilhena. Direitos Fundamentais. Uma leitura da Jurisprudência do STF. São Paulo: Malheiros, 2006, p. 189.

${ }^{290}$ REALE JÚNIOR, Miguel. Limites à liberdade de expressão. Revista Brasileira de Ciências Criminais, a. 17, n. 81, p. 61-91, nov.-dez. 2009, p. 86-87.

${ }^{291} \mathrm{O}$ autor ainda acrescenta: "Nesta tarefa [de ponderação para estabelecimento de ordem de preferência relativa ao caso concreto] do intérprete, especialmente do juiz faz-se uma negociação entre os valores sem que, como se mencionou acima, se possa garantidamente fugir de um subjetivismo, muitas vezes a partir de pressupostos ideológicos. O recurso à ponderação, na hipótese de se reconhecer a ocorrência de um conflito de valores constitucionais, se apresenta [sic] como a única alternativa possível, apesar de não ser 'o manto da ponderação uma terapia segura que evite aberrações morais ou tontices ou um decisionismo vazio de toda a ponderação' (RUBIO LLORENTE, Francisco. Derechos fundamentales e princípios constitucionales, (doctrina jurisprudencial). Barcelona: Ariel, 1995, p. 76). Este subjetivismo verifica-se de forma clara na análise dos votos dos Ministros Gilmar Mendes e Marco Aurélio, ambos fundados na análise do caso concreto, a partir da máxima da proporcionalidade em suas máximas parciais da adequação, da necessidade e proporcionalidade em sentido estrito”. REALE JÚNIOR, Miguel. Limites à liberdade de expressão. Revista Brasileira de Ciências Criminais, a. 17 , n. 81 , p. 61-91, nov.-dez. 2009, p. 82-83.
} 
ponderação, segundo a sua própria percepção do peso que possuem cada direito fundamental e o valor que o mesmo encerra.

No caso Ellwanger, embora os mesmos elementos tenham sido considerados, a única explicação para a diferença obtida nas decisões estaria na distinção entre as preferências expressas nos pesos arbitrários. E essa "arbitragem” de pesos expressaria a arbitrariedade do método da ponderação, o que compromete a racionalidade e justificação das decisões judiciais. Desse modo, embora não se retire do método da ponderação seu valor, valem novas propostas complementares de justificação, como a própria postulação do coerentismo aqui descrita.

\subsubsection{Aplicação do Modelo Coerentista}

A aplicação do modelo coerentista ao caso Ellwanger também permite observar de que maneira o coerentismo auxilia na justificação das decisões judiciais tendo-se em vista as pautas legais, apesar de não assegurar nem a correção e tampouco a objetividade ou univocidades das decisões judiciais.

Nesse sentido, pode-se notar que o modelo coerentista permite justificar o voto do Ministro Relator originário, Moreira Alves, e sua leitura restritiva do tipo penal incriminador e, por outro lado, também a posição antitética do Ministro Relator para o caso, do Ministro Maurício Corrêa, indicado após a aposentadoria do primeiro, profundamente embasada na orientação dada pelo parecer de Celso Lafer, este na condição de amicus curiae, consoante exposto.

Quanto ao voto do Ministro Moreira Alves, nota-se que sua base normativa restringese ao Direito interno e mais especificamente ao contexto histórico nacional. Ao tratar do Art. $5^{\circ}$, XLII da CF, que prevê a imprescritibilidade do crime de racismo, o Ministro aponta que o racismo não abrange toda e qualquer forma de discriminação, não abarcaria em sua amplitude semântica o antissemitismo, devendo ser interpretado de forma estrita.

$\mathrm{Na}$ justificação de tal interpretação, o Ministro invoca a pretensão do legislador constituinte citando a Emenda Aditiva 2P00654-0, apresentada em 12.01.1988, a qual originara o Art. $5^{\circ}$, XLII da CF, tendo este sido inserido em razão do contexto histórico brasileiro, no qual mesmo após a abolição da escravidão, mantiveram-se diferentes formas de discriminação racial, que afetava grande número da população brasileira constituída de negros ou seus descendentes. 
Ademais, não se estenderia a imprescritibilidade ao preconceito contra judeus, primeiramente, porque o Ministro não os entendia como raça; segundo, e com especial relevo, tendo-se em vista a base normativa pátria, cuja diretriz em Direito Penal é de interpretação estrita e favorável ao réu (in dubio pro reo).

O Ministro, opondo-se à interpretação ampliativa proposta por Maurício Corrêa, apontou que este entendimento implicaria ser o racismo tipo de conteúdo aberto, uma vez que os grupos humanos com características culturais próprias são inúmeros e isso levaria a um menoscabo das diretrizes orientadoras da aplicação penal.

Por esta razão, sua decisão fora coerente com o pretenso telos orientador do legislador constituinte na formulação do disposto no Art. $5^{\circ}$, XLII do CF, consistente na busca de se coibir a discriminação racional contra negros, ainda que seja dúbio o discrímen no caso ${ }^{292}$. O que demonstra a vinculação de sua decisão às orientações do legislador constituinte pátrio.

Tanto assim, que o Ministro Gilmar Mendes, reforça, no intuito de afastar críticas ao Ministro Relator, já aposentado quando da decisão final, que Moreira Alves não defendia práticas antissemitas, mas apenas se pautava em interpretação restritiva e histórica, tendo, inclusive, em vista, a intenção do constituinte ao mencionar as discussões sobre a emenda aditiva que originou o inciso XLII do Art. $5^{\circ}$ da CF.

Já no voto do Ministro Maurício Corrêa nota-se a ampliação da base normativa pela inserção de normas de direito internacional: se o ordenamento pátrio levaria a uma interpretação restritiva tal como a do Ministro Moreira Alves, a inserção das normas de Direito Internacional Público relativas à tutela de direitos humanos justifica sua decisão como coerente com esse arcabouço normativo mais amplo.

O Ministro parte da premissa de que as normas internacionais inspiraram e balizaram a atuação da Assembleia Constituinte de 1988 e do legislador ordinário, razão porque a base normativa deveria ser ampliada, abarcando-se os dispositivos correlatos de Direito Internacional Público relativos aos direitos humanos e à matéria do julgamento, preconceito racial; não se restringindo, pois, ao contexto brasileiro.

Entre tais dispositivos, o Ministro Maurício Corrêa cita a Declaração Universal dos Direitos Humanos de 1948, cujo Art. $1^{\circ}$ prevê a liberdade e igualdade entre os homens; a participação do Brasil na Assembleia Geral da Organização das Nações Unidas (ONU) de 1960 contra o racismo, quando se consignou a adesão do Brasil à Convenção Internacional Contra o Genocídio.

\footnotetext{
${ }^{292}$ Poder-se-ia questionar a razoabilidade de se dizer que a ofensa a um negro implicaria imprescritibilidade do crime, mas não a ofensa a um branco, judeu, americano, etc. Não é esse, contudo, o foco da discussão.
} 
Ainda, respalda-se na Convenção Internacional sobre a Eliminação de Todas as Formas de Discriminação Racial de 1965, assinada pelo Brasil e ratificada sem reservas, por meio do Decreto ${ }^{\circ} 65.810$ de 1969 , tendo a Convenção como principal finalidade a definição das formas de racismo em todas as suas dimensões, motivada pelas práticas antissemitas do nazismo e pelo desenvolvimento do apartheid na África do Sul.

O Ministro ainda aponta como base legal o Pacto Internacional sobre Direitos Civis e Políticos de 1966, que prevê a proibição legal de apologia do ódio nacional, racial ou religioso, que constitua incitamento à discriminação, à hostilidade ou à violência; reiterado no Art. 13-5 do Pacto São José da Costa Rica, e incorporado ao Direito brasileiro pelo Decreto Legislativo $n^{\circ}$ 89/98, Decreto $n^{\circ}$ 678/92, e Decreto $n^{\circ} 4463 / 02$.

Finalmente, a fim de sanar dúvidas em relação à amplitude semântica do termo racismo, baseia-se na Resolução 623 da Assembleia Geral da ONU, de dezembro de 1998, a qual instou em seu item 17 os países a cooperar com a Comissão de Direitos Humanos no exame de todas as formas contemporâneas de racismo, elencado como exemplos deste a xenofobia, a negrofobia e o antissemitismo.

Portanto, com base no Direito Internacional Público, restaria indubitável que o antissemitismo seria sinônimo de racismo e, especialmente, por estarem incorporadas a nosso sistema jurídico as normas de Direito Internacional relativas a direitos humanos (até mesmo pelo disposto no Art. $5^{\circ}, \S 2^{\circ}$ da $\mathrm{CF}$, desde que observado o quorum exigido), suas diretrizes teriam inspirado o constituinte e, por tal razão, mereceriam consideração irrestrita pelo intérprete da Constituição Federal.

Tanto, assim, que, para Corrêa, o Deputado Caó, ao justificar a emenda aditiva que inseriu a imprescritibilidade ao crime de racismo, teria se referido também à necessidade de superação das discriminações raciais para a construção de um Estado Democrático, embora a segregação de negros tenha sido o móvel principal de sua inspiração, a justificativa seria em termos plurais, até mesmo porque nos tempos de Brasil colônia, a discriminação contra judeus igualmente se registrou no cenário brasileiro ${ }^{293}$.

Ainda, lembra o Ministro Corrêa que, como nos tratados internacionais ratificados pelo Brasil o racismo alcança a discriminação contra judeus de forma taxativa, há de se entender que a Constituição Federal e a Lei no 7.716/90, que disciplina a discriminação racial, especialmente após alterações introduzidas pela Lei $\mathrm{n}^{\circ} 8.081 / 90$, mantiveram-se fieis aos

\footnotetext{
${ }^{293}$ O Ministro aponta que no período do Brasil colônia os judeus, mesmo os chamados cristãos-novos, eram tidos como "raça infecta" e o preconceito contra judeus seria até mesmo persistente na memória da língua portuguesa, com termos como judiação em indicação a maus-tratos.
} 
compromissos internacionais assumidos pelo Brasil e, por tal razão, pretender dar ao Art. $5^{\circ}$, XLII da CF interpretação diversa e restritiva seria negar toda a ordem jurídica que concebera a positivação dos direitos fundamentais.

Ademais, o Ministro Corrêa ainda apontou o recurso às normas de Direito Internacional pelo STF, citando o Habeas Corpus $\mathrm{n}^{\circ}$ 70389, sob relatoria de Celso de Mello (DJ de 10.08.01) o qual se assentara em atos normativos internacionais como subsídios para a compreensão da noção do crime de tortura, o que também valeria em relação à correta exegese do crime de racismo, pois este, tal como o crime de tortura, feriria os postulados gerais dos direitos humanos.

Com isso, nota-se que os Ministros dão diferente interpretação ao mesmo dispositivo constitucional, embora ambos atenham-se ao direito posto, tendo-se em vista a amplitude da base normativa que adotam. O voto do Ministro Moreira Alves é coerente com sua perspectiva estrita tendo como base normativa o Direito interno e as diretrizes interpretativas em sede penal.

Já o Ministro Maurício Corrêa, ao ampliar a base normativa fazendo inserir normas de Direito Internacional Público endossadas pelo Brasil, decide de modo coerente com essa base mais ampla que permite expandir a abrangência da norma constitucional inserindo-se na discriminação racial também o antissemitismo.

De modo que a diferença de posição resultante do modelo coerentista é reflexo das diferentes bases de regras a serem explicadas e não de preferências entre os aplicadores do modelo, expressando-se, assim, uma racionalidade.

E mesmo a notória divergência no resultado das ponderações de princípios levadas a cabo por Gilmar Mendes e Marco Aurélio Mello, chegando os Ministros a resultados diametralmente opostos, têm coerência com os pesos atribuídos por ambos, ainda que não se tenha meios de aferição objetiva da atribuição de pesos, mas tão só uma atribuição estipulativa, e, embora não haja diretrizes objetivas para se atribuir os pesos, o que acaba levando à subjetividade, quando não à pura arbitrariedade já apontadas.

De toda sorte, essas reconstruções das decisões permitem notar que, no caso, embora não haja critérios objetivos que levem à decisão e, ainda que contrapostas as decisões apontadas, é possível, por meio do modelo coerentista, explicarem-se as decisões tomadas tendo-se em vista o Direito posto, embora as reconstruções normativas por interpretação impliquem resultados distintos. 


\section{CONCLUSÃO}

A discussão do trabalho partiu dos métodos jurídicos, o tradicional método de subsunção e o método da ponderação proposto por Robert Alexy, tendo se calcado, sobretudo, na questão sobre a racionalidade das decisões judiciais em casos de conflito de princípios, apresentando-se os modelos coerentistas como mecanismos para a justificação das decisões judiciais.

O referencial metodológico proposto tanto às ciências exatas quanto às humanas, fruto de um ideal de certeza, segurança e objetividade, fora o método dedutivo, que propunha que a premissa maior já conteria a solução da inferência e, mediante a subsunção da premissa menor - fatos ou eventos - à premissa maior, já estaria predeterminada a conclusão e, por tal razão, esta não inovaria em relação às premissas, pois já estaria contida na premissa maior.

No entanto, no Direito, tal como apontara Karl Engish, a própria construção da premissa maior não seria processo tão simples quanto se supunha, em razão de diversos problemas que exigiriam do julgador uma postura não mecânica ante conceitos indeterminados, conceitos normativos, cláusulas gerais, lacunas normativas ou axiológicas, inconsistências normativas, e mesmo diante de conflito de princípios.

Casos estes cuja tendência é aumentar, em função dos diversos direitos fundamentais que, em democracias constitucionais contemporâneas consagram princípios, que podem entrar em conflito concreto em determinados casos, como factualmente se tem notado em nosso país, especialmente pela ampla divulgação desses casos em meios de comunicação, tal como o próprio caso do aborto de anencéfalos, aqui estudado.

Nesses casos, a solução do conflito exigiria a aplicação do método da ponderação proposto por Robert Alexy como adequado para a solução da colisão de princípios. No entanto, na aplicação desse método, que em sua terceira etapa, da ponderação em sentido estrito, prevê a aplicação da fórmula de peso como meio de se demonstrar os pesos atribuídos, o que daria racionalidade à decisão, não se têm parâmetros objetivos para a atribuição de peso.

O que pareceria levar à incomoda situação de que, em Estados democráticos contemporâneos, por um lado, há salvaguarda de princípios nas Cartas Constitucionais e, por outro lado, sua aplicação leva, não raro, ao menoscabo do princípio da legalidade também consagrado constitucionalmente como essencial à garantia do Estado de Direito. Ou seja, surge o aparente paradoxo entre a ponderação de princípios e a vinculação à lei, visto que o 
método da ponderação parece permitir ao julgador atuar com certa liberdade, sem pautas legais estritas.

Nesse sentido, apontam-se os modelos coerentistas como meios para a justificação das decisões judiciais, alguns dos quais poderiam ser mecanismos para sanar essa aparente incompatibilidade - entre ponderação e vinculação. Mas quando se fala em modelos coerentistas no Direito não há unanimidade, visto que mesmo os modelos coerentistas levam a resultados dissonantes.

Três são as propostas coerentistas clássicas: a de MacCormick, de Peczenik e de Dworkin. Na proposta coerentista de MacCormick, que é fraca, visto que a coerência é necessária, mas não suficiente à justificação das decisões judiciais, a coerência seria garantia apenas de justiça formal, no sentido de se tratarem casos semelhantes de modo semelhante; mas o autor compromete-se com a justiça material e, finalmente, entende que entram em jogo argumentos consequencialistas na justificação das decisões, buscando-se fins e, nestes casos, não há limites ao julgador, posto que o autor reconhece que, finalmente, a vontade pessoal é o elemento determinante da justificação, o que frustra o propósito de racionalidade.

Também Aleksander Peczenik, embora postule com Alexy diversos critérios para a aferição da coerência, que incrementam a proposta coerentista no Direito, por fim, entende que entram no cálculo coerentista tanto razões jurídicas quanto razões morais. Embora reconhecesse que as primeiras teriam um status superior, elas poderiam ser afastadas por considerações morais, de modo que também entenderá que o fator determinante da solução jurídica será baseado em preferências e sentimentos pessoais lastreados na herança cultural do julgador.

A teoria coerentista de Ronald Dworkin está abarcada em sua teoria do direito como integridade, em que o autor propõe a construção do Direito como um todo coerente. Ele ainda avança no sentido de que a coerência e a verdade se implicam e, esta leva à justificação, de modo que as razões de coerência permitiriam a seleção de uma única melhor decisão como justificada, conforme sua tese da resposta correta. Também razões de moralidade política entram em seu cálculo de coerência e, finalmente, sua proposta é acoimada de propor um modelo insuficiente para, pragmaticamente, enfrentar o desafio cético, por ter ele ignorado ou reduzido os limites da razão.

O modelo de Susan Hurley, ajustado ao sistema jurídico de common law, teria a vantagem de trazer orientações ao juiz no ato adjudicativo, ao postular que o julgador se pautasse em casos paradigmáticos, assim entendidos os casos reais ou hipotéticos a respeito dos quais houvesse solução consensual, identificando suas razões subjacentes para ter 
parâmetros para julgar o caso sub judice com base nas mesmas razões e sua ordenação definitiva.

No modelo inferencial, presume-se que o próprio legislador já teria levado a cabo ponderação de princípios ou razões conflitantes em alguns casos, dando primazia a uma delas ao legislar. Assim, tendo-se em vista as razões da lei em casos já solucionados pelo legislador - que valeriam não por sua moralidade, mas por sua legalidade como justificativas da norma posta -, o julgador teria também um norte para a adjudicação concreta em casos de conflito de princípios em que as mesmas razões estivessem em jogo.

A identificação das razões subjacentes à lei que as justificasse seria feita por meio de inferência abdutiva, em busca da melhor explicação para a norma posta, o que, contudo, poderia levar a resultados equívocos, sendo, pois, defensável. De todo modo, seria mecanismo tanto para orientar o julgamento quanto para justificar as decisões judiciais tomadas tendo-se em vista a própria lei.

$\mathrm{Na}$ aplicação desses métodos e modelos, especificamente o inferencial, podem-se extrair algumas constatações. Quanto ao método subsuntivo, sua aplicação tanto ao caso do aborto de anencéfalos quanto ao caso Ellwanger permitiu notar que os resultados, a despeito de obtidos por dedução, foram ou seriam díspares, até mesmo em razão das dissonâncias na própria construção da premissa maior que determina a solução.

Assim, a solução dos casos por subsunção admitiria tanto o entendimento pela subsunção, quanto pela não subsunção e teria a desvantagem de não demonstrar nem o conflito de princípios constatável em ambos os casos - embora não tenha sido cogitado em nenhum dos casos por todos os julgadores, mas por alguns apenas e em graus distintos -, nem o conflito ético envolvido nos temas de julgamento, o que não seria mesmo seu foco, dado o caráter formal desse método.

Já na aplicação do método da ponderação, deparou-se com a grande dificuldade de se saber como efetivamente os Ministros do STF realizaram a ponderação concreta. Isso porque, até mesmo quando diziam aplicar tal método, não o faziam de modo explícito, no sentido de demonstrar as premissas decisórias e mais especificamente os pesos atribuídos a cada princípio e, tampouco demonstraram a aplicação dos passos estabelecidos por Alexy culminando na fórmula de peso não apresentada.

Assim, fora mister a atribuição estipulativa dos pesos, tendo em vista os argumentos apresentados pelos Ministros, a fim de se realizar a aplicação do método da ponderação, que no caso do aborto de anencéfalos permitiu notar que o resultado fora coerente com os pesos atribuídos. Dois dos julgadores, Joaquim Barbosa e Gilmar Mendes teriam efetuado a 
ponderação. Embora ambos tenham dado prevalência à liberdade da mãe em detrimento da vida do anencéfalo, o resultado demonstrou que para Joaquim Barbosa a liberdade seria muito mais substancial, ou seja, dotada de peso muito superior ao considerado por Gilmar Mendes.

Já no caso Ellwanger, a aplicação do método da ponderação invocada por dois dos Ministros, Gilmar Mendes e Marco Aurélio Mello, levou a resultados diametralmente opostos. Gilmar Mendes decidiu pela prevalência da dignidade de judeus e Marco Aurélio Mello pela liberdade de expressão de Ellwanger; o que seria fato denotativo das críticas de que a ponderação leva a resultados díspares e desvinculados da lei.

Quanto à aplicação do modelo coerentista ao caso do aborto de anencéfalos, a decisão do STF parecia em discordância com o sistema normativo resultante do conjunto de artigos envolvendo os Arts. 124 e 126 do CP, bem como o Art. 128, I e II do CP, que prevê as hipóteses de excludente de ilicitude ou aborto permitido, no caso de risco de morte da mãe (aborto terapêutico) e gestação resultante de estupro (aborto sentimental), visto que, à luz dos Arts. 124 e 126 do CP, seria, a rigor (pois a subsunção admitia também solução diversa), vedada a antecipação. No entanto, o Ministro Marco Aurélio permitiu a realização desse procedimento, o que, inclusive, levou alguns dos demais julgadores a acusarem tal decisão de ativismo judicial, por supostamente ser de caráter legislativo - ampliando as hipóteses permissivas do Código Penal.

Contudo, usando inferências abdutivas, é possível explicar a racionalidade e a vinculação à lei da decisão. A dignidade da mãe seria a razão subjacente ao Art. 128, II do CP. Ou seja, na ponderação entre a vida do feto e a dignidade da mãe, afetada por ser a gestação resultante de violência sexual, teria o legislador dado prevalência à dignidade da mulher.

No caso da anencefalia fetal, em que houve dúvida até mesmo sobre a existência ou não de vida do feto, e sob a premissa de que levar a termo uma gestação quando da certeza de morte do nascituro implicaria grave violação à dignidade da mulher, também estariam em colisão os dois princípios (vida e dignidade), tendo o Ministro Marco Aurélio optado, tal como o legislador - o que indicaria a vinculação de sua decisão à lei, a despeito das críticas de ser ativismo - pela dignidade da mãe. Justificando-se, assim, a decisão, tendo por pauta a lei.

No caso Ellwanger, o modelo coerentista também poderia explicar as dissonantes decisões do Ministro Relator originário, Moreira Alves, e do Ministro Relator para o acórdão, Maurício Corrêa, tendo-se em vista a lei. O primeiro decidiu, com base no Direito Interno, pela não subsunção do antissemitismo ao conceito de racismo, ao qual se previra na Constituição Federal, Art. 5 XLII, a imprescritibilidade. 
Ou seja, para o Ministro Moreira Alves, as diretrizes de aplicação penal orientam a interpretação no sentido de que, havendo dúvida, dever-se-ia beneficiar o réu, e o caso ensejaria, por conseguinte, interpretação estrita. Ademais, como na emenda aditiva que inseriria o referido inciso à Constituição, o que se discutia era o preconceito racional contra negro - até pela História pátria -, embora os judeus fossem etnia ou religião ou mesmo raça, consoante a legislação infraconstitucional (Lei ${ }^{\circ} 7.716 / 89$, modificada pela Lei $n^{\circ}$ 8.081/90), não se lhes aplicaria a norma constitucional, até por seu caráter gravoso ao prever a imprescritibilidade.

Já o Ministro Maurício Corrêa pautou-se em normas de Direito Internacional Público relativas à salvaguarda de direitos humanos, abrangendo as relativas a racismo, para entender que o dispositivo constitucional não deveria ser interpretado de forma restritiva, mas ampliativa, abarcando em sua abrangência semântica o antissemitismo, até mesmo porque este fora explicitamente reconhecido como uma forma de racismo pela Resolução 623 da Assembleia da Organização das Nações Unidas, sendo, portanto, sua decisão vinculada à lei e coerente com sua base normativa mais ampla.

Dessa maneira, em essência, o modelo de ponderação consiste em nova deliberação das razões subjacentes à lei, sem qualquer ligação entre a atribuição de "pesos" e o conteúdo das regras aplicáveis. Já o modelo de coerência, particularmente o inferencial, constrange à aplicação dos princípios a partir do conteúdo das regras. É essa relação entre o conteúdo das regras e dos princípios que conferiria racionalidade ao procedimento. 


\section{REFERÊNCIAS}

ALCHOURRÓN, C.; BULYGIN, E. Introducción a la metodología de las ciencias jurídicas e sociales. Buenos Aires: Astrea, 1971.

ALEXY, Robert. Teoria dos Direitos Fundamentais. Tradução de Virgílio Afonso da Silva. São Paulo: Malheiros, 2008.

ALEXY, Robert. On the structure of legal principles. Ratio Juris, v. 13, n. 3, p. 294-304, set. 2000.

ALEXY, Robert. Constitutional Rights, Balancing and Rationality. Ratio Juris, v. 16, n. 2, p. 131-140, jun. 2003.

ALEXY, Robert. Posfácio (2002). In: Teoria dos Direitos Fundamentais. Tradução de Virgílio Afonso da Silva. São Paulo: Malheiros, 2008, p. 575-627.

ALEXY, Robert. On Balancing and Subsumption. A structural Comparison. Ratio Juris, v. 16, n. 4, p. 433-449, dez. 2003.

ALEXY, Robert. La fórmula del peso. Traducción Carlos Bernal Pulido. IN: CARBONELL, Miguel (Coord.). El principio de proporcionalidad y la protección de los derechos fundamentales. México: Comisión Nacional de los Derechos Humanos, 2008, p. 11-37.

ALEXY, Robert. The construction of constitutional rights. Law \& Ethics of Human Rights. v. 4, n. 1, p. 20-32, 2010.

ALEXY, Robert. Ponderación, control de constitucionalidad y representación. In: IBÁÑEZ, Perfeto Andrés; ALEXY, Robert. Jueces y ponderación argumentativa. México: Universidad Federal Autónoma de México, 2006, p. 1-18.

ALEXY, Robert; PECZENIK, Aleksander. The Concept of Coherence and Its Significance for Discursive Rationality. Ratio Juris, v. 3, n. 1, p. 130-147, mar. 1990.

ALISEDA, Atocha. Abductive Reasoning - Logical Investigations into Discovery and Explanation. Dordrecht: Springer, 2006. 
ALISEDA, Atocha. Logic in Scientific Discovery. Foundations of Science, a. 9, p. 339-363, 2004.

AMADO, Juan Antonio García. Ductibilidad Del derecho o exaltación Del juez? Defensa de la ley frente a (otros) valores y princípios. Anuario de Filosofía Del Derecho, v. 13, p. 65-85, 1996.

AMAYA, Amalia. Legal Justification by Optimal Coherence. Ratio Juris, v. 24, n. 3, p. 304329, sep. 2011.

AMAYA, Amalia. Diez Tesis Acerca de la Coherencia en el Derecho. In: ATIENZA, Manuel (Ed.). Discusiones $X-$ la coherencia en el Derecho. Buenos Aires: Universidad Nacional Del Sur, dez. 2011, p. 21-64.

AMAYA NAVARRO, Amalia. An inquiry into the nature of coherence and its role in legal argument. PhD Theses. Department of Law. European University Institute, 2006.

AMAYA NAVARRO, Amalia. La Coherencia en el Derecho. Doxa, no prelo. Disponível em: <http://papers.ssrn.com/sol3/papers.cfm?abstract_id=2049990>. Acesso em: 16 mar. 2012.

ÁVILA, Humberto. Teoria dos Princípios - da definição à aplicação dos princípios jurídicos. 4. ed. rev. 3. tir. São Paulo: Malheiros, 2005.

BOBBIO, Norberto. O Positivismo Jurídico: Lições de Filosofia do Direito. Tradução e notas de Márcio Pugliesi, Edson Brini, Carlos E. Rodrigues. São Paulo: Ícone, 1995.

BONORINO, Pablo Raúl. Sobre la abducción. Doxa, a. 14, p. 207-241, 1993.

BRASIL. Supremo Tribunal Federal. Súmula Vinculante $\mathrm{n}^{\mathrm{o}}$ 11. Disponível em: < http://www.stf.jus.br/arquivo/cms/jurisprudenciaSumulaVinculante/anexo/Enunciados_Sumul a_Vinculante_STF_1_a_29_31_e_32.pdf>. Acesso em: 15 jul. 2012.

BRASIL. Supremo Tribunal Federal. Arguição de Descumprimento de Preceito Fundamental no 54-8/DF. Min. Relator Marco Aurélio Mello. Julgada em 12.04.2012. Pendente de Publicação.

BRASIL. Supremo Tribunal Federal. Questão de Ordem em Arguição de Descumprimento de Preceito Fundamental $\mathrm{n}^{\mathrm{o}}$ 54-8/DF. Min. Relator Marco Aurélio Mello. Julgada em 27.04.2005. D.J. 31.08.2007. Disponível em: 
$<$ http://redir.stf.jus.br/paginadorpub/paginador.jsp?docTP=AC\&docID=484300 $>$. Acesso em: 19 mar. 2012.

BRASIL. Supremo Tribunal Federal. Arguição de Descumprimento de Preceito Fundamental n ${ }^{\circ}$ 54-8/DF. Notas taquigráficas da Audiência Pública de 04 de setembro de 2008. Disponível em:

<http://www.stf.jus.br/arquivo/cms/processoAudienciaPublicaAdpf54/anexo/ADPF54_notas _dia_4908.pdf>. Acesso em: 19 mar. 2012.

BRASIL. Supremo Tribunal Federal. Habeas Corpus $\mathrm{n}^{\circ}$ 84.025-6/RJ. Ministro Relator Joaquim Barbosa. Julgado em 04.03.2004. D.J. 25.06.2004. Disponível em: $<$ http://redir.stf.jus.br/paginadorpub/paginador.jsp?docTP=AC\&docID=384874 >. Acesso em: 21 out. 2011.

BRASIL. Supremo Tribunal Federal. Questão de Ordem em Arguição de Descumprimento de Preceito Fundamental $\mathrm{n}^{\mathrm{o}}$ 54-8/DF. Min. Relator Marco Aurélio Mello. Julgada em 27.04.2005. D.J. 31.08.2007. Disponível em: $<$ http://redir.stf.jus.br/paginadorpub/paginador.jsp?docTP=AC\&docID=484300>. Acesso em: 19 mar. 2012, p. 85.

BRASIL. Supremo Tribunal Federal. Habeas Corpus $\mathrm{n}^{\circ}$ 82.424-2/RS. Ministro Relator Moreira Alves. Ministro Relator para o Acórdão Maurício Corrêa. Julgado em 17.09.2003. D.J. 19.03.2004. Disponível em: <http://redir.stf.jus.br/paginadorpub/paginador.jsp?docTP=AC\&docID=79052>. Acesso em: 21 out. 2011.

BRASIL. Lei $\mathrm{n}^{\mathrm{o}}$ 7.716, de 05 de janeiro de 1989. Disponível em: <http://www.planalto.gov.br/ccivil_03/leis/17716.htm>. Acesso em: 21 out. 2011.

BRASIL. Supremo Tribunal Federal. Habeas Corpus $n^{\circ}$ 70.389/SP. Ministro Relator Sydnei Sanches. Ministro Relator para o Acórdão Celso de Mello. Julgado em 23.06.1994, D.J. 10.08 .2001$. Disponível em: $<$ http://redir.stf.jus.br/paginadorpub/paginador.jsp?docTP=AC\&docID=72400>. Acesso em 21 out. 2011.

BRASIL. Supremo Tribunal Federal. Questão de Ordem em Reclamação no 2040/DF. Ministro Relator Néri da Silveira. Julgada em 21.02.2002. D.J. 27.06.2003. Disponível em: $<$ http://redir.stf.jus.br/paginadorpub/paginador.jsp?docTP=AC\&docID=87540>. Acesso em: 20 out. 2011. 
CARBONELL, Flavia. Coherence and Pos-sovereign Legal Argumentation. In: MENÉNDEZ, Agustín José; FOSSUM, John Erik (Eds.). Law and Democracy in Neil MacCormick's Legal and Political Theory. The Post-Sovereign Constallation, p. 157-182.

CHIBENI, Silvio Seno. A inferência Abdutiva e o Realismo Científico. Cadernos de História e Filosofia da Ciência, série 3, 6 (1), p. 45-73, 1996.

DIMOULIS, Dimitri. A relevância prática do positivismo jurídico. Revista Brasileira de Estudos Políticos. Belo Horizonte, n. 102, p. 215-253, jan.-jun. 2011.

DWORKIN, Ronald. Taking Rights Seriously. Cambridge, MA: Harvard University Press, 1978 .

DWORKIN, Ronald. Law's Empire. Cambridge, MA: Harvard University Press, 1986.

ENGISH, Karl. Introdução ao Pensamento Jurídico. Tradução de J. Baptista Machado. 6. ed. Lisboa: Fundação Calouste Gulbenkian, 1983.

FERRAZ JUNIOR, Tercio Sampaio. A Ciência do Direito. 2. ed. São Paulo: Atlas, 1980.

FERRAZ JUNIOR, Tercio Sampaio. A Hipótese do Legislador Racional e a Noção de Justiça. In: BARBIERI, Catarina; MACEDO Jr., Ronaldo Porto. Cadernos Direito GV: Interpretação, desenvolvimento e instituições - interpretação e objetividade; usos e abusos nas interpretações judiciais; interpretação, política e função. São Paulo, v. 6, n. 3, p. 21-41, mai. 2009.

FERRAZ JUNIOR, Tercio Sampaio. Introdução ao Estudo do Direito: técnica, decisão, dominação. 6. ed. rev. e ampl. São Paulo: Atlas, 2008.

FERREIRA FILHO, Manoel Gonçalves. Aspectos do Direito Constitucional Contemporâneo. 2. ed. São Paulo: Saraiva, 2009.

GRAU, Eros Roberto. Ensaio e Discurso sobre a Interpretação/Aplicação do Direito. 5. ed. rev. e ampl. São Paulo: Malheiros, 2009.

GUASTINI, Riccardo. Ponderación: un análisis de los conflictos entre principios constitucionales. Palestra del Tribunal Constitucional Revista mensual de jurisprudencia, Lima, a. 2, n. 08, p. p. 631-637, ago. 2007. 
HAGE, Jaap. Studies in Legal Logic. Dordrecht: Springer, 2005.

HAGE, Jaap; PECZENIK, Aleksander. Law, Morals and Defeasibility. Ratio Juris, v. 13, n. 3, p. 305-325, sep. 2000.

HARMAN, Gilbert H. The Inference to the Best Explanation. The Philosophical Review, v. 74, n. 1, p. 88-95, jan. 1965.

HART, Herbert L. A. El concepto de Derecho. Traducción de Genaro R. Carrió. Buenos Aires: Abeledo-Perrot, 1963.

HARTSHORNE, Charles, WEISS, Paul, BURKS, Arthur (Orgs.). The Collected Papers of Charles Sanders Peirce. Cambridge, MA: Harvard University Press, 1931-35 e 1958. 8 v.

HEMPEL, Carl G. Deductive-Nomological vs. Statistical Explanation. Minnesota Studies in the Philosophy of Science, n. 3, p. 98-169, 1962.

HEMPEL, Carl G.; OPPENHEIM, Paul. Studies in the logic of explanation. Philosophy of Science, v. 15, n. 2, p. 135-175, apr. 1948.

HURLEY, Susan L. Coherence, hypothetical cases, and precedent. Oxford Journal of Legal Studies, p. 221-251, 1990.

HURLEY, Susan. Natural Reasons: personality and polity. Oxford University Press: New York, 1989.

KRESS, Kenneth. Why No Judge Should Be a Dworkinian Coherentist. Texas Law Review. V. 77, p. 1375-1427, 1999.

LAFER, Celso. O caso Ellwanger: anti-semitismo como crime da prática do racismo. Revista de Informação Legislativa, Brasília, a. 41, n. 162, p. 53-89, abr./jun. 2004.

LAFER, Celso. A internacionalização dos Direitos Humanos. Constituição, Racismo e Relações Internacionais. Barueri, SP: Manole, 2005.

LARENZ, Karl. Metodologia da Ciência do Direito. 3. ed. Tradução de José Lamego. Lisboa: Fundação Calouste, 1997. 
MACCORMICK, Neil. Legal reasoning and legal theory. New York: Oxford University Press, 2003.

MACCORMICK, Neil. Rethoric and the Rule of Law: a theory of legal reasoning. Oxford: Oxford University Press, 2005.

MACCORMICK, Neil. Coherence in Legal Justification. In: PECZENIK, A. et al (eds.) Theory of Legal Science: Proceedings of the Conference on Legal Theory and Philosophy of Science. Dordrecht: Reidel Publishing Company, 1984, p. 235-251.

MARANHÃO, Juliano Souza de Albuquerque. Inclusivismo Lógico: uma contribuição à metodologia jurídica. Tese de livre-docência, Departamento de Filosofia e Teoria Geral do Direito, Universidade de São Paulo, São Paulo, 2010.

MARANHÃO, Juliano Souza de Albuquerque. Coherencia en el derecho: conservadurismo y fidelidad a la base de reglas. In: ATIENZA, Manuel (Ed.). Discusiones $X-$ la coherencia en el Derecho. Buenos Aires: Universidad Nacional Del Sur, dez. 2011, p. 179-215.

MARANHÃO, Juliano Souza de Albuquerque. Positivismo jurídico lógico-inclusivo. São Paulo: Marcial Pons, 2012.

MARTINS, Argemiro Cardoso Moreira; ROESLER, Cláudia Rosane; JESUS, Ricardo Antonio Rezende de. A noção de coerência na teoria da argumentação jurídica de Neil MacCormick: caracterização, limitações, possibilidades. Revista Novos Estudos Jurídicos Eletrônica, v. 16, n. 2, p. 207-221, mai.-ago. 2011, p. 217. Disponível em: <http://siaiweb06.univali.br/seer/index.php/nej/article/view/3281/2064>. Acesso em 18 jan. 2012.

MICHELON, Claudio, Principles and Coherence in Legal Reasoning (Princípios e Coerência na Argumentação Jurídica) (Portuguese). U. of Edinburgh School of Law Working Paper, n. 2009/08, 31 mar. 2009. Disponível em: <http://ssrn.com/abstract=1371140>. Acesso em: 01 mar. 2011.

MORESO, José Juan. Alexy y la aritmética de la ponderación. IN: CARBONELL, Miguel (Coord.). El principio de proporcionalidad y la protección de los derechos fundamentales. México: Comisión Nacional de los Derechos Humanos, 2008, p. 63-75.

NIINILUOTO, Ilkka. Defending Abduction. Philosophy of Science, v. 66, p. S436-S451, 1999. 
NOZIK, Robert. The Nature of Rationality. Princeton, New Jersey: Princeton University Press, 1993.

OLIVEIRA JÚNIOR, José Alcebíades. Casos Difíceis no Pós-Positivismo. In: BOUCAULT, Carlos Eduardo de Abreu; RODRIGUEZ, José Rodrigo (Orgs.). Hermenêutica Plural. São Paulo: Martins Fontes, 2005, p. 203-228.

PAAVOLA, Sami; HAKKARAINEN, Kai. Three Abductive Solutions to the Meno Paradox - with instinct, inference, and distributed cognition. Studies in Philosophy and Education, a. 24, p. 235-253, 2005, p. 237 e 249.

PECZENIK, Aleksander. Law, Morality, Coherence and Truth. Ratio Juris, v. 7, n. 2, p. 146176, jul. 1994.

PECZENIK, Aleksander. Scientia Iuris - An Unsolved Philosophical Problem. Ethical Theory and Moral Practice, v. 3, n. 3, p. 273-302, sep. 2000.

PECZENIK, Aleksander. On Law and Reason. Lund: Springer, 2008.

PEIRCE, Charles Sanders. Semiótica. São Paulo: Perspectiva, 1977.

PULIDO, Carlos Bernal. La ponderación como procedimiento para interpretar los derechos fundamentales. In: Problemas contemporáneos de la filosofía del derecho. Colombia: Universidad Autonoma De Mexico, 2005, p. 17-35.

PULIDO, Carlos Bernal. La racionalidad de la ponderación. IN: CARBONELL, Miguel (Coord.). El principio de proporcionalidad y la protección de los derechos fundamentales. México, DF: Comisión Nacional de los Derechos Humanos, 2008, p. 39-61.

PULIDO, Carlos Bernal. Estructura y límites de la ponderación. Doxa, n. 26, p. 225-238, 2003.

PULIDO, Carlos Bernal. La racionalidad de la ponderación. In: CARBONELL, Miguel (Coord.). El principio de proporcionalidad en el Estado constitucional. Bogotá: Universidad Externado de Colombia, 2007, p. 51-80, 2007.

RAMOS, Elival da Silva. Parâmetros dogmáticos do ativismo judicial em matéria constitucional. Tese apresentada à Faculdade de Direito da Universidade de São Paulo para 
inscrição em concurso público visando ao provimento de cargo de professor titular. São Paulo, 2009.

RAZ, Joseph. The relevance of coherence. Boston University Review, v. 72, n. 2, p. 273-231, mar. 1992.

REALE JÚNIOR, Miguel. Limites à liberdade de expressão. Revista Brasileira de Ciências Criminais, a. 17, n. 81, p. 61-91, nov.-dez. 2009.

RODRIGUEZ, José Rodrigo. "Quanto terá sido o óbvio...”: o debate sobre o formalismo em textos escolhidos (Prefácio). IN: RODRIGUEZ, José Rodrigo (Org.). A Justificação do Formalismo Jurídico - textos em debate. São Paulo: Saraiva, 2011, p. 7-11.

RODRIGUEZ, José Rodrigo. Controlar a profusão de sentidos: a hermenêutica jurídica como negação do subjetivo. In: BOUCAULT, Carlos Eduardo de Abreu; RODRIGUEZ, José Rodrigo. Hermenêutica Plural: possibilidades jusfilosóficas em contextos imperfeitos. São Paulo: Martins Fontes, 2005, p. 277-307.

SANCHÍS, Luis Prieto. El juicio de ponderación constitucional. IN: CARBONELL, Miguel (Coord.). El principio de proporcionalidad y la protección de los derechos fundamentales. México, DF: Comisión Nacional de los Derechos Humanos, 2008, p. 77-113.

SANTAELLA, Lucia. O método anticartesiano de C. S. Peirce. São Paulo: UNESP, 2004.

SCHIAVELLO, Aldo. On "Coherence" and "Law": An Analysis of Different Models. Ratio Juris, v. 14, n. 2, p. 233-243, jun. 2001.

SILVA, Virgílio Afonso da. Princípios e regras: mitos e equívocos acerca de uma distinção. Revista Latino-Americana de Estudos Constitucionais, v. 1, p. 607-630, 2003.

SILVA, Virgílio Afonso da. O proporcional e o razoável. Revista dos Tribunais, a. 91, v. 798, p. 23-50, abr. 2002.

SORIANO, Leonor Moral. A Modest Notion of Coherence in Legal Reasoning. A Model for the European Court of Justice. Ratio Juris, v. 16, n. 3, p. 296-323, sep. 2003.

SOUZA, Marcelo Alves Dias de. Do precedente judicial à súmula vinculante. 1. ed. 3. reimp. Curitiba: Juruá, 2008. 
THAGARD, Paul R. The Best Explanation: Criteria for Theory Choice. The Journal of Philosophy, v. 75, n. 2, p. 76-92, feb. 1978.

VIEIRA, Oscar Vilhena. Supremocracia. Revista Direito GV, n. 4, v. 2, p. 441-464, São Paulo, jul.-dez. 2008.

VIEIRA, Oscar Vilhena. Direitos Fundamentais. Uma leitura da Jurisprudência do STF. São Paulo: Malheiros, 2006.

VILLA, Vittorio. Normative Coherence and Epistemological Pressupositions of Justification. In: NERHOT, Patrick (Ed.). Law, Interpretation and Reality. Essays in Epistemology, Hermeneutics and Jurisprudence. Dordrecht: Kluwer Academic Publishers, 1990, p. 431-455.

VON WRIGHT, Georg Henrik. Explanation and Understanding. London: Routledge \& Kegan Paul, 1971.

ZORRILLA, David Martínez. Conflictos Constitucionales, Ponderación e Indeterminación Normativa. Madrid: Marcial Pons, 2007.

ZORRILLA, David Martínez. Conflictos Constitucionales, Ponderación e Indeterminación Normativa. Tesis Doctoral. Universidad Pompeu Fabra, Barcelona, 2004. 